\title{
Rubens Meister
}

Três projetos em Curitiba

Henrique Wosiack Zulian

Dissertação apresentada à Faculdade de Arquitetura e Urbanismo da Universidade de São Paulo para obtenção do título de Mestre em Arquitetura e Urbanismo.

Orientadora: Profa. Dra. Marta Vieira Bogéa

Área de concentração: Projeto de Arquitetura 
Autorizo a reprodução e divulgação total ou parcial deste trabalho, por qualquer meio convencional ou eletrônico, para fins de estudo e pesquisa, desde que citada a fonte.

E-mail do autor: henriquezulian@gmail.com

Zulian, Henrique Wosiack

Rubens Meister: Três obras em Curitiba / Henrique

Wosiack Zulian; orientadora Marta Vieira Bogéa. - São

Paulo, 2020

$192 \mathrm{p}$.

Dissertação (Mestrado) - Faculdade de Arquitetura e

Urbanismo da Universidade de São Paulo. Área de

concentração: Projeto da Arquitetura.

1. Arquitetura Moderna. 2. Projeto de Arquitetura. 3.

Meister, Rubens, 1922-2009. I. Bogéa, Marta Vieira, orient.

II. Título. 


\section{Agradecimentos}

À professora Marta Bogéa pela sua orientação precisa, firme e leve ao mesmo tempo, e pela enorme contribuição na organização e realização deste trabalho.

Aos meus pais, Rosângela e Carlan, pelo apoio irrestrito, força, compreensão e constante incentivo na continuidade da atividade acadêmica.

Ao arquiteto Fábio Domingos Batista pela imensa generosidade e pelo precioso material bruto fornecido.

Ao arquiteto Salvador Gnoato pelos ensinamentos e estímulos com a pesquisa.

Às professoras Juliana Suzuki e Mônica Junqueira pelos importantes esclarecimentos e comentários realizados na banca de qualificação.

Aos professores das disciplinas de pós-graduação Hugo Segawa, Maria Cristina Leme e Luís Antônio Jorge pelas valiosas considerações durante as aulas

Aos amigos e colegas de profissão que colaboraram direta ou indiretamente ao longo da pesquisa: a Claudionor Beatrice pelas conversas e trocas. À Elizabeth Amorim de Castro pela contribuição com materiais. À Isabel Meister pela condução ao acervo. A Juaréz Guimarães pelas informações e arquivos. A Moacir Zancopé por estreitar laços em um momento importante do trabalho. 



\section{Resumo}

Este estudo propõe uma leitura de três obras emblemáticas desenvolvidas por Rubens Meister, pioneiro da arquitetura moderna paranaense, em Curitiba. Visa reconhecer essa produção no contexto de transformação da cidade a partir de meados do século XX e identificar questões relevantes de sua arquitetura.

O primeiro capítulo relata uma breve apresentação da trajetória profissional do engenheiroarquiteto e a sua atuação no espaço construído da capital paranaense. O segundo, terceiro e quarto capítulos estão dedicados ao estudo de cada uma das obras selecionadas: Teatro Guaíra (1948-1951), Palácio 29 de Março (1960) e Estação Rodoferroviária de Curitiba (1969). A partir dessas análises, busca-se compreender a relação dos edifícios com o lugar e identificar aspectos recorrentes nas estratégias projetuais de Meister. Ao final do trabalho foi anexado um índice contendo um conjunto reconhecido das suas obras construídas.

O material remanescente do seu escritório, bem como os livros Espirais de Madeira: Uma História da Arquitetura de Curitiba (DUDEQUE, 2001), Rubens Meister: Vida e Arquitetura (SUTIL; GNOATO, 2005) e Rubens Meister: Projeto e Obra (CARVALHO; BATISTA; CHIESA, 2019), serviram como base fundamental de dados para o desenvolvimento desta pesquisa.

Palavras-chave: Arquitetura Moderna, Projeto de Arquitetura, Rubens Meister, Curitiba, Teatro Guaíra, Palácio 29 de Março, Estação Rodoferroviária de Curitiba 



\section{Abstract}

This study proposes a reading of three emblematic works developed by Rubens Meister, a pioneer of modern architecture in Paraná, in Curitiba. It aims to recognize this production in the context of the city's transformation from the mid-20th century onwards and to identify relevant features of its architecture.

The first chapter reports a brief presentation of the professional career of the engineerarchitect and his role in the built space of the capital of Paraná. The second, third and fourth chapters are dedicated to the study of each of the selected works: Guaíra Theater (1948-1951), 29 de Março Palace (1960) and Curitiba Railway Station (1969). Based on these analyzes, we seek to understand the relationship of these buildings with the place and identify recurrent aspects in Meister's design strategies. At the end of the work, an index containing a recognized set of his constructed works was attached

The remaining material from his office, as well as the books Espirais de Madeira: Uma História da Arquitetura de Curitiba (DUDEQUE, 2001), Rubens Meister: Vida e Arquitetura (SUTIL; GNOATO, 2005) and Rubens Meister: Projeto e Obra (CARVALHO; BATISTA; CHIESA, 2019), served as a fundamental database for the development of this research.

Key words: Modern Architecture, Architecture Project, Rubens Meister, Curitiba, Guaíra Theater, 29 de Março Palace, Curitiba Railway Station 


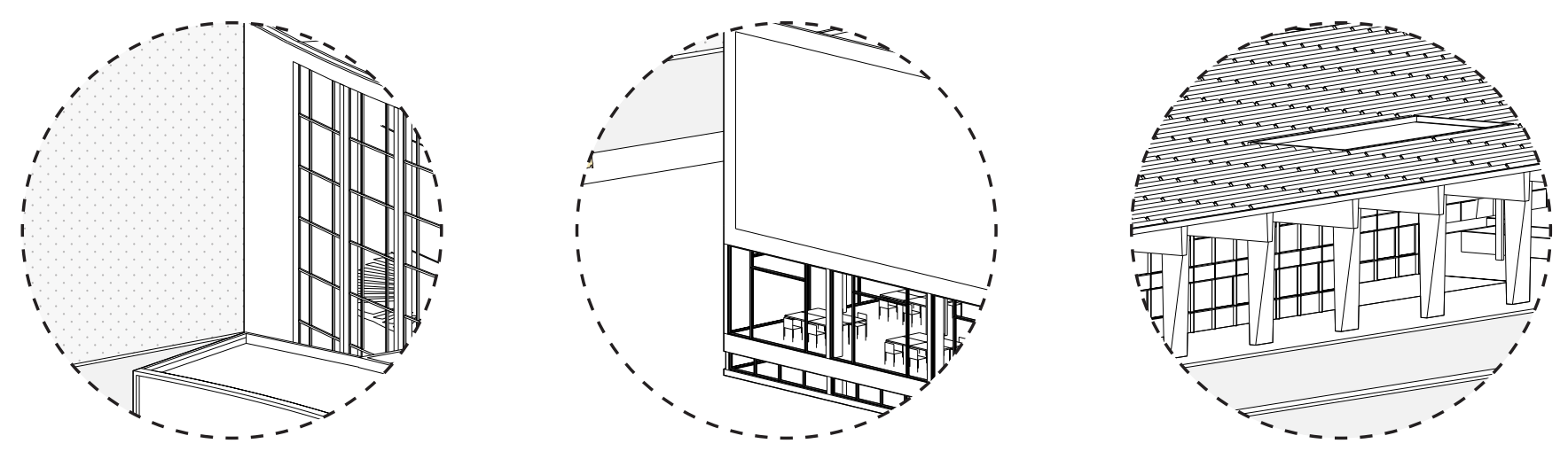



\section{Sumário}

Introdução

I Rubens Meister e Curitiba

1 Antecedentes

2 Primeiras manifestações

3 Início da atividade profissional

3 Amadurecimento e rigor construtivo

4 Uma arquitetura moderna e orgânica

II Teatro Guaíra

1 Introdução

2 Análise de projeto

3 Conclusões

III Palácio 29 de Março

1 Introdução

2 Análise de projeto

3 Conclusões

IV Estação Rodoferroviária de Curitiba

Introdução

Conclusões gerais 



\section{Apresentação}

Esta pesquisa encontra sua origem em 2008. Em meio a minha graduação tomei conhecimento do trabalho de Rubens Meister a partir de notícias de um triste episódio, o seu falecimento. O "pai" do Teatro Guaíra, do Palácio 29 de Março, dos edifícios Avenida, da Caixa Econômica Federal e da Rodoferroviária de Curitiba havia se despedido. Algo me chamou a atenção: o autor de edifícios tão emblemáticos não era tão reconhecido no âmbito arquitetônico fora de Curitiba. Em seguida, me deparei, com surpresa, com uma enorme dificuldade em achar materiais sobre seus projetos.

Os contatos com suas obras, no entanto, competem a memórias anteriores. As idas à capital foram constantes em minha vida. Nasci e cresci em Ponta Grossa, à 114 quilômetros de distância. Alguns familiares e, posteriormente, amigos, moraram lá. Nas visitas, de alguma forma, eu via na Estação Rodoferroviária uma das "caras de Curitiba". Quando me deslocava de ônibus, os trinta e um pórticos comunicavam que eu havia chegado à capital. Já o Teatro Guaíra me soava "estranho": "porque ele não é um teatro antigo como os das outras grandes cidades?", me perguntava.

Mas é durante a pesquisa que me deparo com questões ainda mais próximas. A imersão em suas obras trouxe a tona projetos "desconhecidos" de Meister, no entanto, muito conhecidos por mim nas experiências pela cidade. O já inexistente prédio do SENAI de Ponta Grossa, vizinho da casa em que cresci, fez parte do cenário da minha infância na rua. O Cine Renascença (depois conhecido como Cine Inajá) foi a casa de filmes mais popular desta mesma cidade e local em que tive o privilégio de frequentar constantemente.

A partir destes encontros, o trabalho nasceu e configurou uma procura por um elo entre a necessidade de uma pesquisa e o interesse em viabilizar acesso às obras de Rubens Meister somado ao estudo e reconhecimento próprio das ferramentas e estratégias da prática de projeto. 



\section{Introdução}

O presente trabalho nasceu da intenção de fazer um levantamento de um conjunto de obras de Rubens Meister que, apesar de reconhecidas por profissionais da História e da Arquitetura em solos paranaenses, ainda tem pouco alcance em meio ao panorama da arquitetura moderna brasileira.

Meister, apesar da formação em Engenharia Civil, foi fundador do primeiro curso de Arquitetura e Urbanismo no Paraná e é considerado o precursor da arquitetura do movimento moderno no estado. Foi na explosão da economia paranaense dos anos 1940 e 1950 que sua arquitetura apareceu. Com seu escritório produzindo somente projetos arquitetônicos (primeiro entre os estados do Paraná e Santa Catarina), concebeu edificações que logo tornaram-se notórios agentes na transformação do cenário urbano de uma Curitiba ainda dominada pela arquitetura eclética. É, todavia, em concomitância a Meister que a arquitetura moderna começa a se solidificar como linguagem oficial nas construções do estado e, posteriormente, dos empreendimentos privados.

O primeiro objetivo desta pesquisa consiste em recorrer a projetos de Rubens Meister que possam auxiliar na compreensão do seu raciocínio projetual através de um conjunto de abordagens específicas. Apesar do pouco conhecimento historiográfico acerca do engenheiroarquiteto, o trabalho não tem a pretensão de analisar a sua obra como um todo ${ }^{1}$, mas elucidar soluções e pensamentos projetuais que foram importantes na construção do seu repertório profissional a partir de alguns estudos de caso.

Esses estudos correspondem ao escopo da pesquisa. Contudo, a busca de Meister por uma nova arquitetura favorecida pelo contexto (político, social e material) propício como o de 
Curitiba nos anos 1940 condicionou a um segundo objetivo: uma leitura sobre a relação entre um importante agente da transformação do território construído e o solo urbano de uma capital que se transformava e visava evidenciar e valorizar a construção do espaço público. Buscou-se assim, compreender a importância do engenheiro-arquiteto na construção deste cenário.

Tratando-se de um trabalho que permeia territórios pouco ou recém explorados, o terceiro objetivo visa abrir novos espaços de reflexão sobre o valor do objeto em questão e sua relação com a arquitetura moderna brasileira.

A elaboração da presente dissertação consistiu, inicialmente, em um processo baseado em pesquisas bibliográficas acerca do cenário histórico e arquitetônico em Curitiba e no Paraná e sobre Rubens Meister. Simultaneamente foi feito um levantamento do acervo de obras arquivadas na residência de Rubens Meister (figura 1), construída em 1955 e ainda habitada pela sua família. Muitos dos levantamentos realizados para o livro Rubens Meister: Projeto e Obra (CARVALHO; BATISTA; CHIESA, 2019), que estavam em andamento durante boa parte desta pesquisa, foram cedidos e aqui utilizados como referências de dados e desenhos

Logo, buscou-se uma compreensão da dimensão do seu trabalho ao longo da carreira. 0 levantamento inicial se atentou às obras que haviam sido contempladas no currículo oficial de Meister e que somavam um total de 105 edificações (organizadas em ficha no Anexo deste trabalho). Deste modo, esses projetos foram somados a outros descobertos, que possuíam informações relacionadas por data e que não estavam presentes em seu currículo. Organizados pelo pesquisador em uma linha do tempo (ao final do Capítulo I, p.56) resultaram em 111 obras construídas. Uma outra porção de projetos edificados, ausentes de data, foram dispostos em uma segunda parte da ficha de obras, também presente no Anexo da pesquisa.

No entanto, um total de 399 projetos foram reconhecidos pelos pesquisadores de sua obra a partir de um caderno de projetos localizado em seu acervo (CARVALHO; BATISTA; CHIESA, 2019, p. 358-362). Ao contrário do seu currículo oficial, nessas anotações de Meister as informações possuem algumas lacunas (alguns projetos com ausência de data, localidade e até nome)

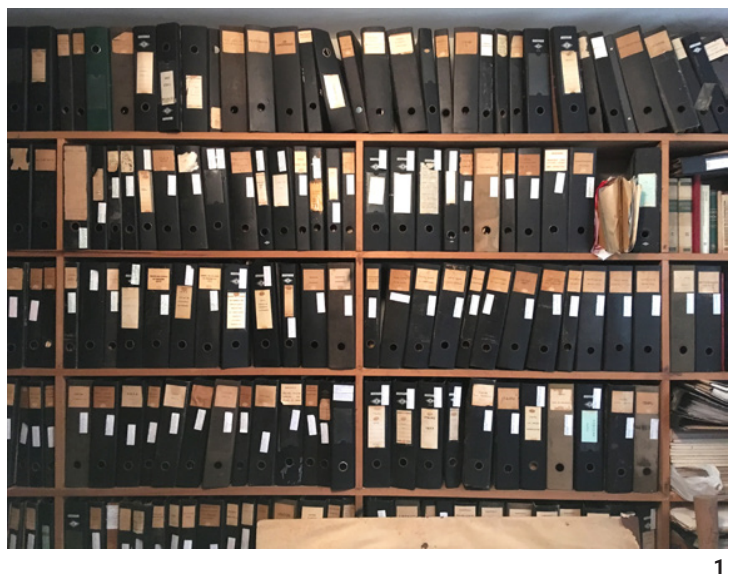

Figura 1: Acervo Rubens Meister Fonte Acervo do autor. 
Destes, 274 (cerca de 69\%) foram realizados para a cidade de Curitiba.

Foram contabilizadas publicações em 11 livros que contemplaram 31 diferentes projetos, variando entre rápidas leituras e análises mais aprofundadas. Tomando como base estes dados, foram reunidas informações de forma a sistematizar a produção de Rubens Meister ao longo da carreira e a relevância destas publicações.

É digna de nota a predominância da sua arquitetura na capital paranaense e a relevância dos seus projetos na sua transformação urbana. Buscou-se então realizar um levantamento dessas obras a partir de aproximações locais. A possibilidade da experiência de visitação a estes projetos também é relevante no aprofundamento da pesquisa (os edifícios contemplados neste primeiro momento estão marcados no mapa da página seguinte). A vivência e o levantamento iconográfico, a partir de um olhar pessoal, serviram de auxílio tanto às análises quanto ao registro e comunicação destas obras. As fotografias aqui apresentadas são, em sua grande maioria, resultados destas aproximações. Elas permitiram uma grande imersão na obra de Meister e acabaram ilustrando a presente pesquisa. O fato destas obras ainda resistirem com certa integridade e estarem passíveis de visitação, auxiliou no recorte e na leitura e culminou em uma melhor compreensão dos resultados obtidos.

Conforme a pesquisa se delineava, tornou-se imprescindível estabelecer uma direção que permitisse um olhar mais atento e "demorado" sobre os princípios projetuais de Meister. Para isso, foram delimitadas três obras notoriamente reconhecidas por pesquisadores, que estabeleçam relações diretas com o espaço público de Curitiba e que permitem reconhecer transformações de seu pensamento em arquitetura ao longo da sua atividade profissional. Neste momento, houve um retorno a esses projetos: novas visitas e levantamentos fotográficos e bibliográficos foram realizados

É sabido que as informações sobre a sua obra e o alcance da sua bibliografia são escassos fora do estado do Paraná. Contudo, considerou-se prudente desenvolver, em uma parte inicial deste trabalho, um breve panorama do engenheiro-arquiteto situando-o no contexto da 
arquitetura brasileira, salientando sua presença no cenário urbano de Curitiba e sua posição de destaque no pioneirismo da modernidade paranaense.

No Capítulo I buscou-se compreender o período de formação do engenheiro-arquiteto, o contexto arquitetônico da cidade de Curitiba e a relação "mutualística" entre Rubens Meister e a capital paranaense. 0 momento efervescente da cidade foi propício ao início da sua carreira e sua resposta não foi passiva, mas de enfrentamento e ruptura com o cenário à sua volta. Os relatos deste capítulo inicial serão abastecidos de imagens relacionadas ao tema e também de levantamentos iconográficos realizados pelo autor desta pesquisa, que complementam o texto e dão sustentação ao método por aproximação.

A história de Meister, pessoal e profissional, está generosamente contada nas páginas dos livros Rubens Meister: Vida e Arquitetura (SUTIL; GNOATO, 2005) e Rubens Meister: Projeto e Obra (CARVALHO; BATISTA; CHIESA, 2019). Muitas informações dessas obras permeiam a pesquisa e foram fundamentais para a mesma.

Os três capítulos seguintes são reservados à leitura de três projetos visando estabelecer instrumentos para a reflexão sobre trabalho de Rubens Meister. Para isso, parte-se da singularidade de cada caso. O intuito foi o de se debruçar sobre os edifícios e adentrar a pormenores que possam traduzir e sintetizar questões recorrentes em sua prática projetual ao longo da sua atividade profissional, sem a pretensão de classificar ou resumir sua vasta obra.

Estas aproximações têm início no Capítulo II com o projeto para o Teatro Guaíra (19481951) que simboliza o início da atividade do engenheiro-arquiteto como profissional. Este momento mostra como Rubens Meister, recém-formado em engenharia, buscava referências na arquitetura brasileira e internacional e as aplicava em solos ainda dominados pelo ecletismo. No Capítulo III, o projeto analisado é o Palácio 29 de Março (1960), também conhecido como Paço Municipal de Curitiba. Trata-se do edifício que contempla as atividades administrativas da Prefeitura Municipal de Curitiba e que foi, posteriormente, incorporado ao complexo do Centro Cívico do Estado do Paraná (1951). A década de 1960 mostrou o amadurecimento de Meister 
como profissional e a solidificação de seu escritório como um dos principais do estado do Paraná.

O projeto para a Estação Rodoferroviária de Curitiba (1969), tratado no Capítulo IV, antecedeu o período de maior inflexão no raciocínio projetual de Rubens Meister. Estas mudanças estão descritas no Capítulo I e algumas delas podem ser observadas neste projeto. Foi também no final da década de 1960 e início da década de 1970 que o engenheiro-arquiteto passou a desenvolver um número menor de projetos públicos em Curitiba e se concentrar mais em residências unifamiliares e no interior do estado do Paraná e Santa Catarina.

Esclarece-se que a capital paranaense buscava a modernização e organização de seu crescimento através dos planejamentos urbanos do Plano Agache a partir de 1943. “Em termos gerais, Curitiba hoje é mais conhecida pela qualidade de seus espaços urbanos do que pela produção arquitetônica de seus edifícios." (CARVALHO; BATISTA; CHIESA, 2019, p. 32). Apesar dessas três obras estarem atreladas de diferentes formas ao urbanismo da cidade, elas têm o seu protagonismo e expressam a construção da ideia de uma Curitiba moderna: o Teatro Guaíra (1948-1951) é o ápice da materialização cultural do estado do Paraná e da sua capital, o Palácio 29 de Março (1960) é a sede do poder municipal e a Rodoferroviária (1969) é uma crucial porta de acesso à cidade. Possuem, dessa forma, grande capacidade de síntese de aspectos da obra de Meister, sendo que cada uma comunica um momento particular e importante na sua carreira. É válido destacar que as obras do Teatro Guaíra - primeiro projeto analisado - duraram até 1974, apenas dois anos após a conclusão da Rodoferroviária - terceiro projeto analisado - em 1972.

O sistema de imersão em cada projeto também teve como base metodológica a análise gráfica. Pautada pela reconstrução e restituição de cada obra a partir de desenhos em duas e três dimensões, tal atividade foi dedicada a identificar aspectos inerentes a essa arquitetura e a cada caso específico. Esta metodologia de trabalho permitiu comparações de soluções entre diferentes projetos e indicar, ao mesmo tempo, procedimentos usuais em diferentes situações, procurando, assim, identificar as características destacadas e mais recorrentes 
dessa arquitetura e relacioná-las à demais referências já consolidadas no período.

Logo, essa investigação buscou alcançar alguns princípios que nortearam a sua produção dentro da história da arquitetura moderna brasileira no período citado, procurando contribuir para o conhecimento da prática de projeto do arquiteto. As abordagens para análise foram escolhidas como consequência da leitura do panorama geral das obras de Rubens Meister e buscaram, dessa maneira, permitir um modo de investigação atento às qualidades dessa arquitetura.

Entende-se, contudo, que em meio a sua extensa produção em arquitetura, o recorte selecionado pode implicar em certas limitações no alcance do trabalho. Entretanto, o objetivo de realizar essas aproximações a partir de casos específicos buscou trazer à tona alguns aspectos mais relevantes em sua obra.

Algumas leituras de outros temas tornaram-se referências significativas durante o processo de pesquisa e tiveram importante contribuição na organização do presente trabalho.

A primeira delas foi a dissertação de mestrado de Luciano Margotto Soares, A arquitetura de Álvaro Siza: Três estudos de caso (2001). A pesquisa funcionou como referência de análise arquitetônica levando-se em conta os seguintes aspectos: a) a busca por recorrências nas obras em questão que guiam o método analítico; b) a análise a partir de uma unidade, utilizando-a como memória de quem a projetou; c) o desenvolvimento gráfico como análise de soluções e comunicação dos resultados; d) a investigação com caráter sistemático, detendo-se ao objeto e evitando postura dogmática, visando o reconhecimento, através de estudos de caso, de ideias importantes na obra do autor sem necessariamente examinar a carreira como um todo.

Outra referência metodológica foi Colin Rowe em The Mathematics of the Ideal Villa (1976), que apresenta o desenho como ferramenta de pesquisa permitindo aprofundamento e reflexão crítica da arquitetura em questão.

Outras abordagens para pesquisa em projeto serviram como metodologia para o trabalho através de diferentes frentes. É o caso de Padrões de Intenção (BAXANDALL, 2006), que traz uma 
proposta metodológica de abordagem do contexto a partir de fatos individuais e na identificação e compreensão da singularidade de um caso particular. Em torno do objeto, o raciocínio do autor consiste em enumerar os principais pontos da narrativa que sugerem a existência de uma causa. Explica-se dessa forma as ações que tratam o documento e não ele em si, ou seja, não explicamos a obra, mas a descrição que fazemos dela.

Hélio Piñon, no livro Teoria do Projeto (2007) explica a importância do (re)desenho no processo de análise e compreensão do projeto como forma de aprendizado prático em arquitetura. Destaca também a importância da reprodução gráfica do artefato na escala do detalhe, principalmente naquilo que concerne a visualidade da edificação perante a cidade e sua resultante plástica. Muitos dos projetos utilizados como exemplos no livro são apresentados de forma transparente, ou seja, mostra-se um edifício, a relação visual e compositiva de uma fachada e os pormenores de sustentação estética destes elementos.

Essas propostas metodológicas, todavia, funcionaram como amparo na construção de uma análise que busca partir do contexto urbano em questão na medida em que se aproxima do objeto e adentra a pormenores particulares de cada caso. 


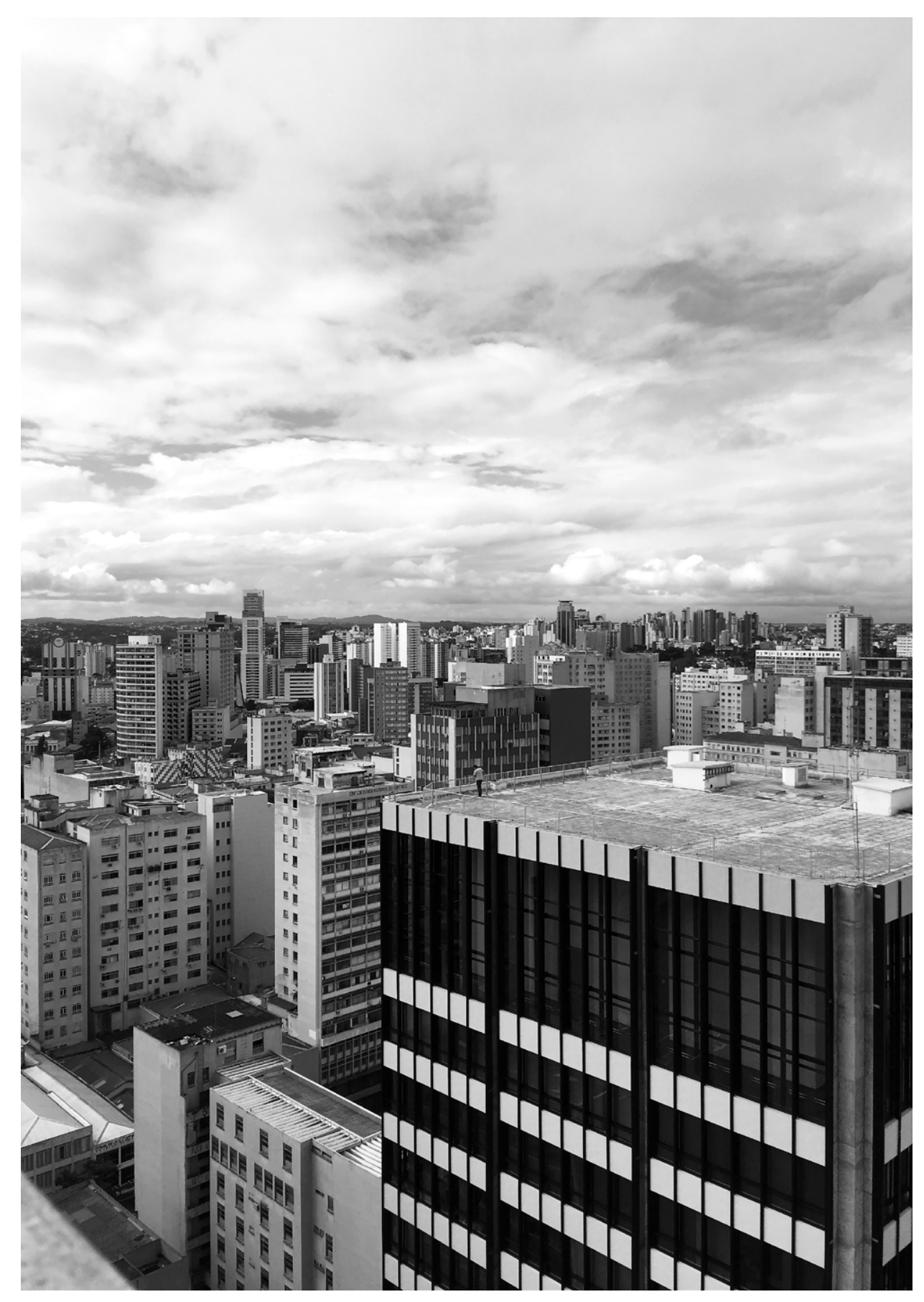


Rubens Meister e Curitiba 
Figura 2(capa do capítulo): O Edifício da Caixa Econômica Federal (1967) e sua inserção no centro de Curitiba. Fonte: Acervo do autor. 


\section{Antecedentes}

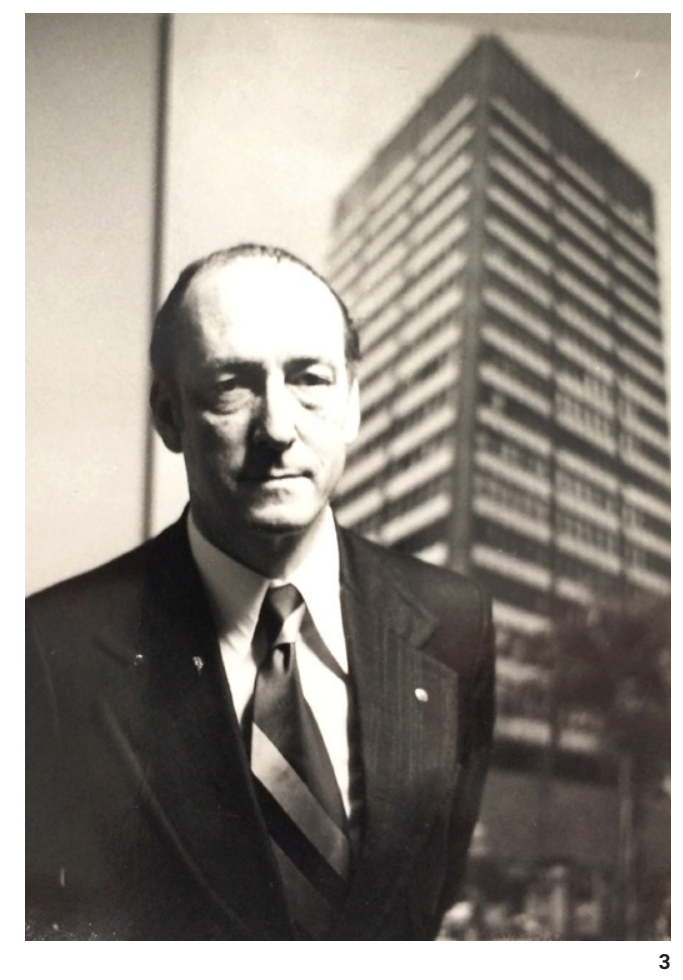

Figura 3: Rubens Meister Fonte: Acervo Rubens Meister.
"Em 1851 ou 52, num navio chamado Florentin, eles vieram para a América, era o sonho na ocasião. E falavam em São Francisco. Muitos contam - e eu não sei se isso é verdade, pode até ser - que quando vieram no navio a vela, a viagem levava praticamente três meses; chegaram em São Francisco, perguntaram onde estavam e responderam: "São Francisco". Eles perguntaram: "São Francisco da Califórnia?" E responderam: "Não, São Francisco do Sul!" E eles:

"Serve!" "

(MEISTER, 1995 in SUZUKl; BERRIEL, 2012, p.49)

Rubens Meister nasceu em Botucatu, São Paulo, em 31 de janeiro de 1922 durante uma curta passagem de sua família pelo interior paulista. Seu pai, Alvino Meister, havia sido transferido, a trabalho, de Curitiba pouco antes. Retornaram após alguns meses, quando o filho havia completado apenas cinco meses de idade.

Seus familiares, vindos da Suíça, desembarcaram no porto de São Francisco do Sul, em Santa Catarina. Uma parte da família estabeleceu-se em Joinville, outra, foi a Porto Alegre, um terceiro grupo, que incluía o seu avô, subiu em direção ao $1^{\circ}$ planalto paranaense. "Na capital paranaense, a família foi morar em uma casa situada à Praça Santos Andrade, próxima a sede histórica da Universidade Federal do Paraná, onde se deu o desenrolar da família e do futuro engenheiro." (CARVALHO; BATISTA; CHIESA, 2019, p.41).

Vítima de poliomielite com apenas dois anos de idade e em uma época de difícil tratamento, Meister nunca recuperou totalmente os movimentos da perna direita. A mesma perna que, poucos anos depois, sofreu uma fratura decorrente de um acidente em uma brincadeira com o 
irmão. A fratura mal calcificada ampliou a dificuldade de locomoção que o acompanhou a vida inteira. (SUTIL; GNOATO, 2005, p. 12).

Dotado de grande sensibilidade artística, Meister descobriu cedo a paixão pelos desenhos e pela construção ainda quando estudante da ala alemã do Colégio Bom Jesus, a Deutsche Knabenschule. Um de seus colegas de classe dessa época foi Romeu Paulo da Costa², com quem posteriormente estudou e lecionou engenharia e desenvolveu projetos em conjunto.

Curitiba, na década de 1940, possuía apenas três cursos: direito, medicina e engenharia (MEISTER in BERRIEL; SUZUKI, 2012, p. 52). Tornar-se engenheiro civil pela Universidade do Paraná ${ }^{3}$ era o único caminho para quem tinha pretensões de trabalhar com arquitetura. "Em 1945, não era fácil ser arquiteto em Curitiba, por dois motivos simples: não existir curso de arquitetura e não existir um atelier de arquiteto propriamente dito, onde se pudesse ingressar para trabalhar e aprender." (GOMES, E. R. 1995 apud GNOATO, 2009, p.87). Logo, Rubens Meister iniciou o curso preparatório em 1942 para em seguida procurar empregos que pudessem custear seus estudos.

"Nesta ocasião comecei a trabalhar num escritório de construção.

Escritório de arquitetura não existia aqui. Existia escritório de construção. Passei um ano desenhando, e aprendi logo no começo

qual é a espessura de um tijolo (...)Saí de lá e fui procurar uma

empresa de construção. Na ocasião a Irmãos Thá era a mais conceituada empresa aqui na construção de casas, de habitações. (...) Entrei em contato com um problema muito sério na arquitetura que é a construção. Aprendi tudo que se referia à construção de habitações, todos os mínimos detalhes, tudo. Fiquei quatro anos trabalhando lá. 


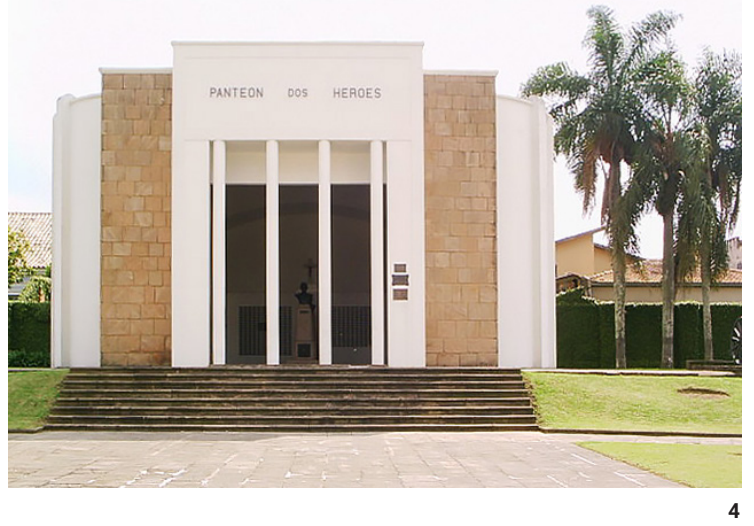

Figura 4: Panteão dos Heróis da Lapa (1943). Disponivel em: <http://wikipedia. org/wiki/Panteão_dos_Heróis>. Acesso em: 13.dez.2019
Um ano após adentrar ao curso preparatório realizou seu primeiro concurso público de arquitetura. Junto a Romeu Paulo da Costa, foi premiado em primeiro lugar no concurso nacional de projetos para o Panteão dos Heróis da Lapa (1943) (figura 4). O projeto de aspirações modernas foi fruto das escolhas progressistas e independentes de Meister ante ao conservadorismo ainda presente nas matérias de arquitetura da faculdade. O presidente da comissão julgadora do concurso, David Carneiro ${ }^{4}$, incentivou o estudante a cursar arquitetura na Escola Nacional de Belas Artes. Após juntar dinheiro, decorrente do seu trabalho como desenhista na empresa de construção Irmãos Thá, se aventurou em direção ao Rio de Janeiro.

O retorno a Curitiba foi rápido, Meister declarou-se aborrecido com o clima quente e com os projetos que estavam sendo apresentados pelos alunos nas fases finais de graduação. Poucos meses depois, decidiu prosseguir com o curso de engenharia (MEISTER in BERRIEL; SUZUKI, 2012, p. 54)

"A arquitetura começa a ser exercida quando se estuda, projeta e constrói. No fim da década de 40, quando me formei, Curitiba já possuía [sic] cerca de 200.000 habitantes, e já possuía [sic] há muito tempo seus arquitetos. Quanto a mim, é difícil precisar o momento

que comecei efetivamente a exercer arquitetura. Desde a idade em que se começa a raciocinar e pensar sobre o futuro, tive forte inclinação para a arte de construir. Naquela época, o único caminho
4 David Antônio da Silva Carneiro (1904-1990) foi engenheiro, historiador, "positivista", escritor, poeta e professor de "Arquitetura Analítica" 2a Escola de Belas Artes do Paraná de Economia Universidade Federal do Paraná e de História na Universidade de Braślia (UNBB). Fonte:

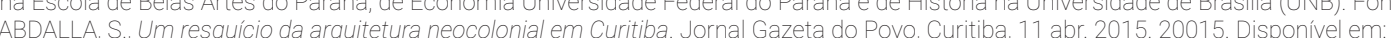
khttps://www.gazetadopovo.com.br/imoveis/um-resquicio-da-arquitetura-neocolonial-emcuritiba-o-passado-que-resiste-a-modernidade-7rh5g09poo6for2iekcsdtr6b/>. Acesso em: 28.dez.2019. 
para se obter diploma de arquiteto no Brasil era em São Paulo ou no Rio de Janeiro. Como as atribuições profissionais do engenheiro eram as mesmas, o recurso para se obter aqui as mesmas atribuições era

através da engenharia."

(MEISTER in ZEIN, 1986, p. 40)

Logo após sua formatura, em 1947, recebeu o convite para ser o $1^{\circ}$ assistente da disciplina de Construção Civil - Arquitetura na universidade em que fora formado. Dois anos após, assumiu como Catedrático Interino da mesma disciplina, onde mais tarde, teve novamente ao seu lado Romeu Paulo da Costa, agora como seu assistente. 


\section{Primeiras manifestações}

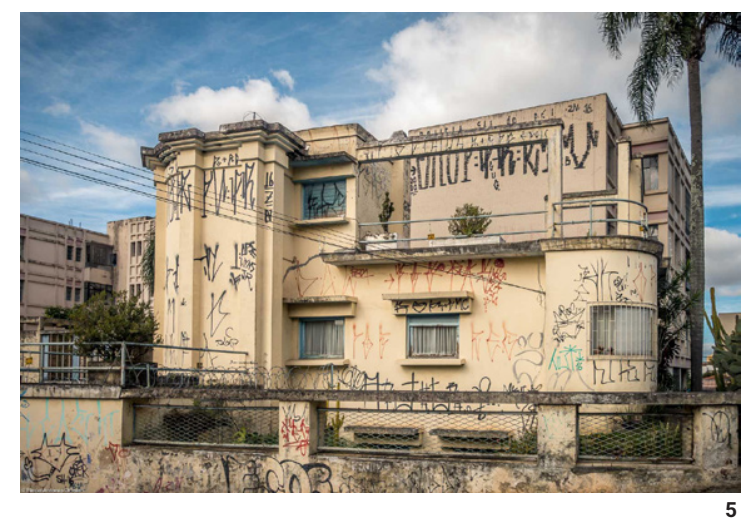

No início da década de 1920, o estado do Paraná estava prestes a completar setenta anos de existência como unidade autônoma e independente da $5^{\circ}$ Comarca Político-Administrativa de São Paulo ${ }^{5}$. O momento dava início a um período que alguns historiadores chamam de Paraná Moderno $^{6}$, onde o estado passava por um processo de plena expansão territorial rumo ao seu interior ocidental e planejavam-se novas cidades em ritmo acelerado. A cidade de Curitiba contava com aproximadamente 90.000 habitantes e, em meio aos sobrados ecléticos e ruas de pedra ou barro, a preocupação que rondava o poder público era conter os surtos de tifo (DUDEQUE, 2010, p.33-45). A capital foi adquirindo "novas feições" ao longo da década, "alargaram antigas vias e abriram novas, promoveram desapropriações, pavimentaram ruas barrentas e incentivaram construções" (SUTIL, 2009, p.145). A arquitetura neocolonial ganhava força e ameaçava o fim do ecletismo (SUTIL, 2009, p. 146).

O autor da Casa Kirchgässner (figura 5), que se tem como primeiro registro de arquitetura moderna no Paraná, Frederico Kirchgässner ${ }^{7}$, relata que a obra feita para ele e sua família em 1929 deixou, em suas palavras, "a cidade perplexa” (KIRSCHGÄSSNER, 1971 apud GNOATO, 2017). Kirchgässner era arquiteto formado por correspondência em 1928 pela Deutsche Kunstchule de Berlim. Trabalhou no Departamento de Urbanismo da Prefeitura de Curitiba onde entrou como desenhista em 1916 e ficou até a sua aposentadoria. A importância deste primeiro registro é destacada por Alberto Xavier em Arquitetura Moderna em Curitiba (1985), onde o

Figura 5: Casa Kirchgässner (1929) de Frederico Kirchgässner. Disponível em $<$ htto:/lwwefotografandocuritibacom br/2018/02/casa-kirchgassner-importante-para.html>. Acesso em: 14.jan.2019

5 A região pertencente ao estado do Paraná, bem como a parte oeste do estado de Santa Catarina faziam parte da comarca paulista até 6 CARD 19 de dezembro de 1853 . e Jayme Cardoso atribuem dois momentos de ocupação do território do Paraná: Paraná Tradicional e Paraná Moderno Já o historiador Ruy Wachowicz divide em três: Paraná Tradicional, Norte do Paraná e Frente Sulista (WACHOWICZ, 2002 p 287). 7 Friedrich Kirchgässner (1899-1988) nasceu em Karlsruhe Alemanha e chegou ao Brasil com um ano de idade mais precisamente na cidade de Ibirama, Santa Catarina. Ainda criança mudou-se para Curitiba, onde estudou na Deutsche Knabenschule, escola em idioma alemão (GNOATO, 2017) 
autorestabelece paralelos temporais com o movimento de Gregori Wachavchik ${ }^{8}$ em São Paulo.

"Essas manifestações, rigorosamente contemporâneas às de Gregori Warchavchik em São Paulo, acham-se presentes em duas residências, construídas para seu irmão Bernardo, à rua Visconde

de Nacar e para seu próprio uso, na rua 13 de Maio. Esta última, implantada em terreno acidentado, com vista da cidade e domínio panorâmico da Serra do Mar - hoje perdidos com as construções vizinhas -, é executada com estrutura de concreto armado, assumindo presença significativa o emprego de grande área aterraçada." (XAVIER, 1985, p.11)

O projeto para a casa de Bernardo Kirchgässner é de seis anos depois (1936), sendo que as presenças isoladas destas duas residências modernas ganhariam novas companhias no início da década de 1940.

As obras modernas que deram sequência a Kirchgässner tiveram autoria de João Batista Vilanova Artigas, engenheiro-arquiteto nascido em Curitiba e formado pela Escola Politécnica da Universidade de São Paulo em 1937. A casa José Mehry (1942) reintroduziu Artigas na sua volta ao Paraná, como profissional. Em 1944 desenvolveu duas casas para cada um de seus irmãos, Joel e Giocondo e outra para João Átilo Rocha.Em 1945 projetou o Hospital São Lucas (figura 6). No mesmo ano, desenhou outras três casas em Curitiba: a primeira residência de Álvaro Correia de Sá e as de Innocente Vilanova Jr. e Coraio Bernardi (sendo apenas esta última construída) além de uma em Ponta Grossa, de Orlando Holzmann.

Com exceção da segunda casa de Álvaro Correia de Sá (1949) em Ponta Grossa e a de João

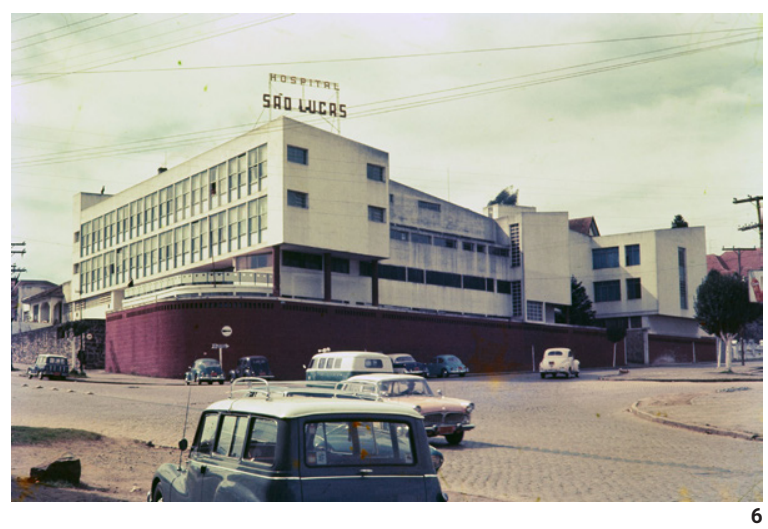

Figura 6: Hospital São Lucas (1945) de Vilanova Artigas Disponível em < <htp: / vilanovaartigas.com>. Acesso em 14.jan.2019. 


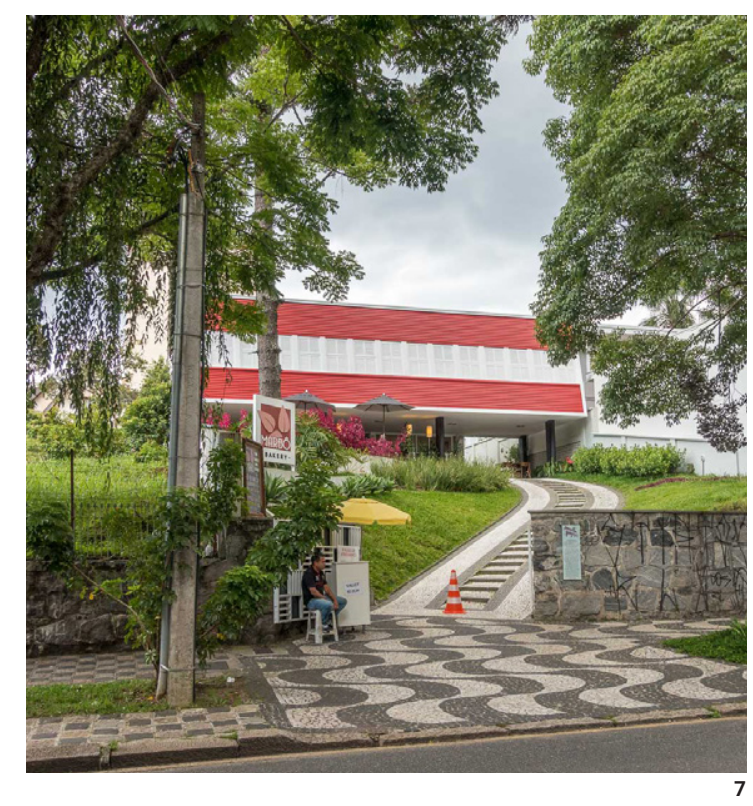

Figura 7: Casa Romário Pacheco/Belott (1953) de Ayrton "Lolô' Cornelsen. Fonte Flávio Antônio Ortolan. Disponível em: chttp://www.fotografandocurithac Acesso em: 20.jan.2020
Luís Bettega (1949) em Curitiba, os projetos que se sucederam rumavam ao novo e crescente norte do estado, mais especificamente em Londrina. Dentre eles, destacam-se: o Cine Ouro Verde (1948) e a Rodoviária de Londrina (1950). Entre projetos que não foram executados ao longo de quase duas décadas, somente em 1978 Artigas voltou à Curitiba com uma obra construída, a casa de Edgard Niclewicz.

As obras do engenheiro-arquiteto Ayrton "Lolô" Cornelsen ${ }^{9}$ também datam do início do movimento moderno no Paraná. Cornelsen entrou no curso de engenharia da Universidade do Paraná em 1943 e finalizou sua graduação em arquitetura na Escola de Belas Artes do Rio de Janeiro, retornando à Curitiba em 1949. Participou do concurso para o Teatro Guaíra em 1948 também com um projeto moderno que, no entanto, não esteve entre os finalistas. Entre as obras desta fase inicial, destacam-se: as residências Chácara do Lolô (1949), Cleusa Cornelsen (1949), Marcos Axelrud (1953), Romário Pacheco/Belotti (1953) (figura 7) e a Sede do DER (1955).

Promotor de transformações na cidade e na vida de seus moradores, o pensamento moderno, concretizado por esses engenheiros-arquitetos, difundia-se pelo país de forma sistemática nesse período, obtendo sua projeção máxima através da arquitetura moderna carioca e suas decorrentes exposições e publicações mundo afora. O arquiteto Irã Dudeque sintetiza no seu livro Espirais de Madeira (2001), como estas transformações ocorreram regionalmente:

"Houve vantagens nestas confusões. Quando Kirschgässner importou ideias das vanguardas russas e alemãs, foi visto como um pândego, um futurista. A residência que Artigas projetou para seus irmãos foi apelidada de estrebaria. Quando Lolô Cornelsen propôs formas derivadas de Corbusier para residências parecia loucura. Quando Rubens Meister projetou o Teatro Guaíra, baseado

9 Ayrton "Lolo" Cornelsen (1922 - ) é engenheiro-arquiteto, foi secretário de transportes do Paraná e ex-jogador do Club Athletico Paranaense. Trabalhou em projetos de estádios como o Pinheirão e nos autódromos de Estoril (Portugal), Jacarepaguá, Pinhais e Luanda (Angola) Sua arquitetura foi de grande importância no cenário moderno paranaense sendo um dos precursores do movimento no estado. 
em Corbusier e Niemeyer, os positivistas duvidavam que tais formas perdurassem. Com as linhas de móveis, um novo design entrou nas residências. Com os financiamentos, a pequena burguesia adquiriu residências com um novo aspecto. Com a maquete do Centro

Cívico à mostra, e depois o próprio, em construção, as novas formas

passaram a ser aceitas."

(DUDEQUE, 2001, p.190-191)

Nesse mesmo momento do texto o autor conclui:

"A elite intelectual de Curitiba não sabia do panteísmo de Louis Sullivan, nem do misticismo platônico das vanguardas construtivas, nem das disputas entre "modernos" e "modernistas". Sabia o que era o Centro Cívico, o Teatro Guaíra e as novas residências. Não eram

mais estranhezas. Estavam catalogadas. Eram funcionais." (DUDEQUE, 2001, p.190-191)

Tanto no âmbito público como privado, esse rico contexto constituiu a base de boa parte do que veio a ser realizado por Meister nos anos subsequentes, como será visto a seguir. 


\section{Início da atividade profissional}

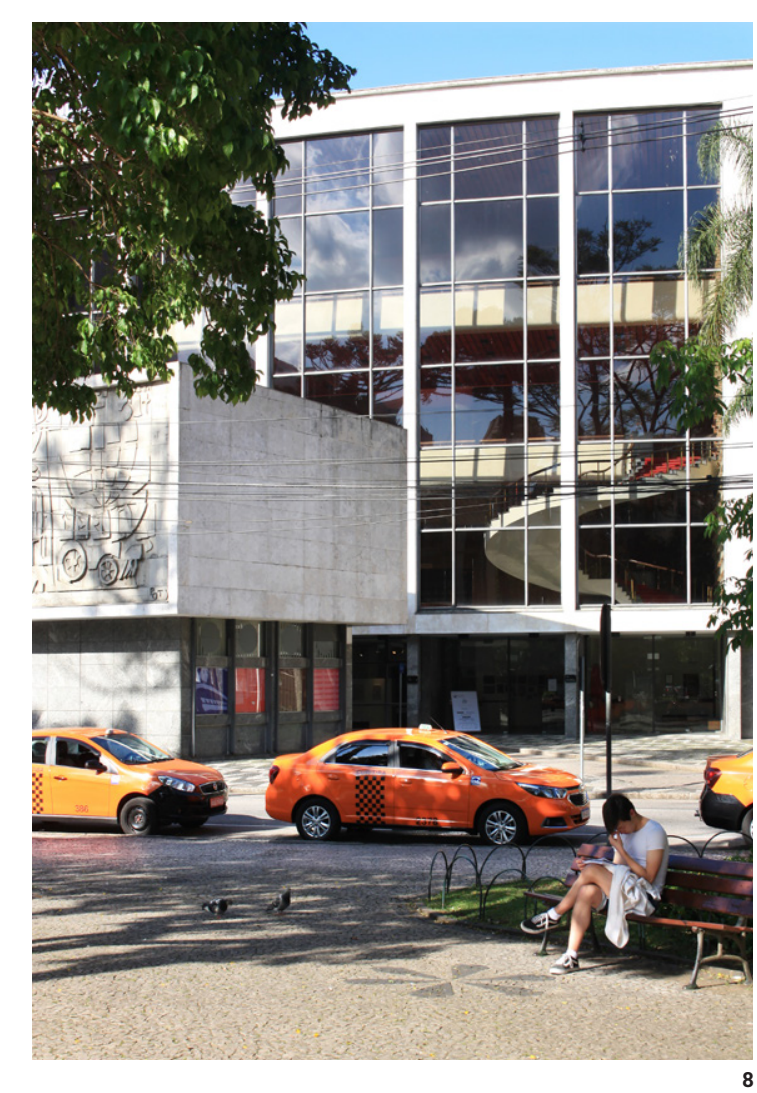

Figura 8 (acima): Teatro Guaira (1948-

1951). Fonte: Acervo do autor.
Apenas um ano após finalizar a graduação, Meister decidiu participar do concurso nacional de arquitetura para o novo Teatro Guaíra em 1948 promovido pelo governador Moysés Lupion. Trabalhava no período noturno, único momento possível pelo fato de ocupar o posto de projetista do quartel general durante este ano. Em parceria com o engenheiro de estruturas Eugênio Grandinetti, obteve o terceiro lugar sendo os dois primeiros colocados projetos ecléticos realizados por grandes empresas de engenharia ${ }^{10}$.

Contudo, em 1950, após tomar posse e entusiasmado com as comemorações do Centenário de Emancipação Política do Paraná em 19531, o governador Bento Munhoz da Rocha ${ }^{12}$ passou a adotar um discurso de que a capital "deveria espelhar ares progressistas" (SUTIL; GNOATO, 2005, p.37). Os jornais da época já haviam publicado manifestos contrários à escolha do vencedor do concurso, o que influenciou o governador a escolher o projeto de Meister para o novo teatro ${ }^{13}$

Entre novas demandas e projetos, Meister fundou seu próprio escritório em 1950 e teve a partir de 1951 um novo sócio, o engenheiro Osíris Silveira Lepca ${ }^{14}$. O primeiro contrato importante após o Teatro Guaíra (figura 8) foi o projeto da Casa Renaux (1952) (figura 9) no centro de Curitiba. A fachada composta por cobogós chamava a atenção em meio ao entorno eclético e estampou revistas e livros da década de 1950 (CARVALHO; BATISTA; CHIESA, 2019,

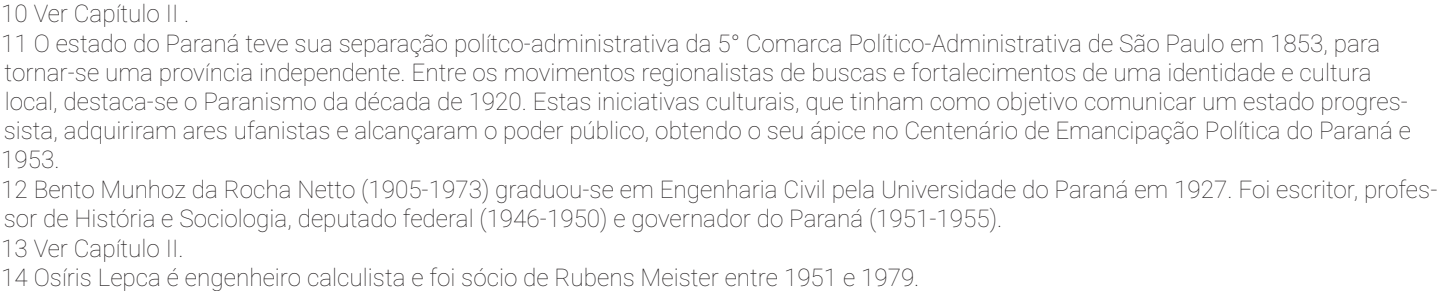


p.123). As paredes de quinas suavizadas e a plasticidade do desenho do mezanino e escada eram vistos também nos projetos do Teatro Guaíra (1948-1951) e do Grupo Escolar Tiradentes (1951). Com bons honorários, houve possibilidade financeira de iniciar o projeto e execução da própria residência (1955) (SUTIL; GNOATO, 2005, p.22).

Levando-se em conta os projetos que realizou durante os anos de estudos e início de carreira, fica impreciso indicar quando o mesmo começou a trabalhar com arquitetura de fato, como descreve em depoimento a Ruth Verde Zein: para ele sua carreira teve início em 1948, um ano após sua formação, ao desenvolver a proposta para o Teatro Guaíra (MEISTER in ZEIN, 1986, p.40).

A partir de 1954 passou a trabalhar exclusivamente com projetos arquitetônicos, o primeiro escritório entre os estados de Paraná e Santa Catarina. No mesmo ano, a construtora Aranha Sociedade Anônima tinha um projeto em um terreno no centro de Curitiba próximo à praça General Osório que, para os donos do empreendimento, não se encontrava arquitetonicamente bem resolvido. As obras já haviam sido iniciadas e Meister foi contratado para resolver as questões levantadas. Trata-se do icônico Edifício A.S.A. (1954) (figuras 10 e 11).

Com o dinheiro vindo dos cafezais do norte, o estado vivia um bom momento econômico e a Universidade Federal do Paraná investia constantemente em sua expansão depois de federalizada em 1951. Após Rubens Meister ter executado sua proposta para a Capela da Reitoria da Universidade Federal do Paraná (1951), a instituição solicitou propostas arquitetônicas para o Complexo da Reitoria, Faculdade de Filosofia, Ciências Econômicas e Auditório. Meister apresentou sua proposta, entretanto a escolhida foi a do arquiteto paranaense, radicado no Rio de Janeiro, David Xavier Azambuja (CARVALHO, BATISTA, CHIESA, 2019, p.147). As obras tiveram início em 1954, sendo que o bloco do auditório foi substituído por um projeto de Meister (CARVALHO, BATISTA, CHIESA, 2019, p.148). Logo, o Auditório da Reitoria (1955) (figura 12) foi concebido para 700 pessoas, abrigadas abaixo de uma cobertura estruturada por quatro pórticos organizados sob uma malha modular radial.
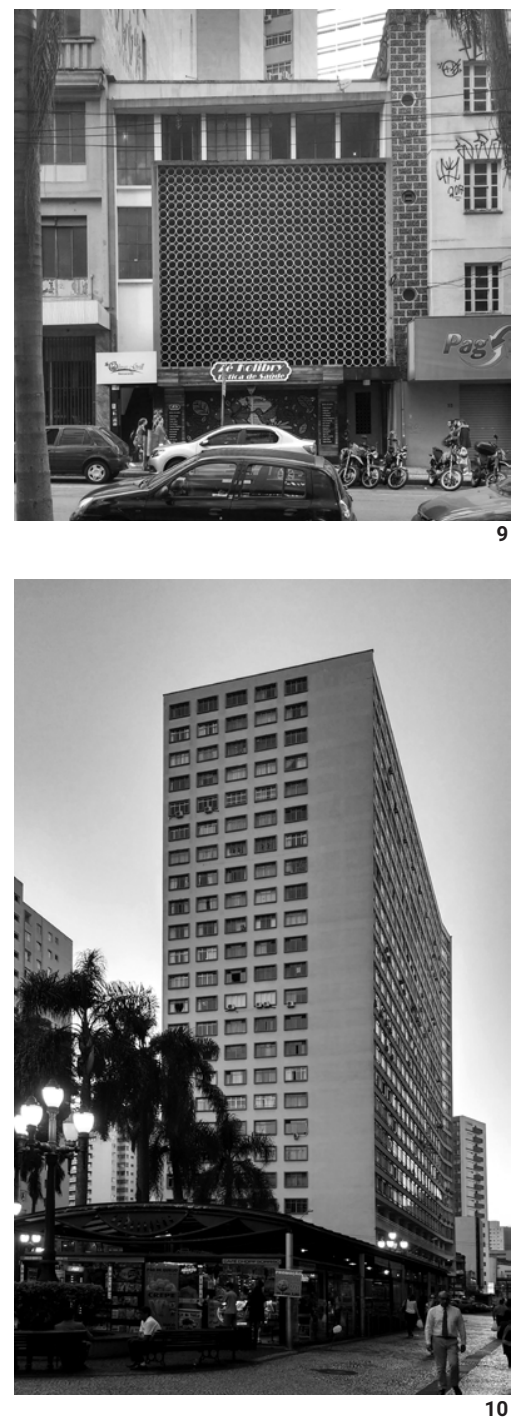

Figura 9 (acima): Casa Renaux (1952). Fonte: Acervo do autor

Figura 10 (abaixo): Edifício A.S.A. (1954) Fonte: Acervo do autor 
Fiqura 11: Edifício A.S.A. (1954). Fonte: Acervo do autor.

Figura 12: Auditório da Reitoria (1955) Fonte: Acervo Salvador Gnoato.
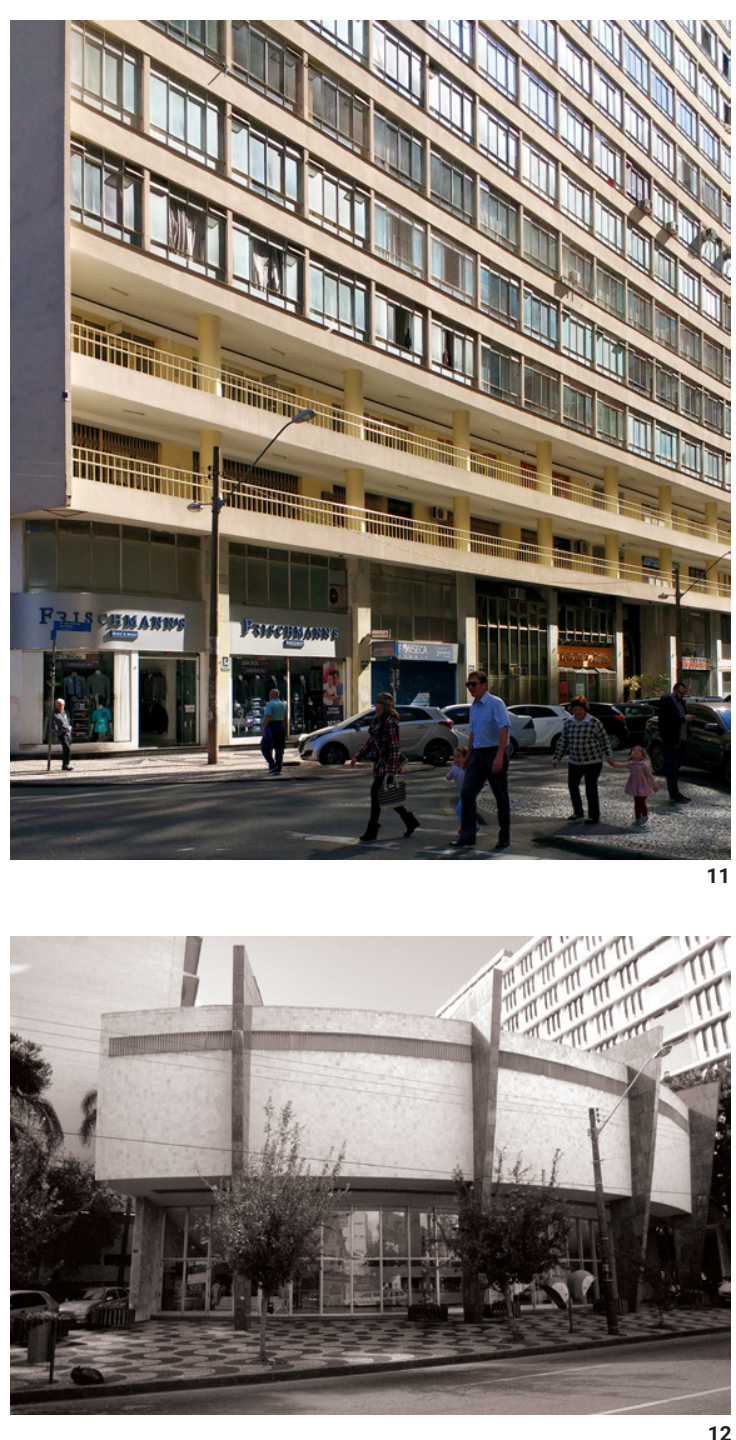

Estes projetos derivam de uma visão de Meister que estava ainda muito atenta ao que vinha se construindo no Rio de Janeiro. Era a arquitetura que seguia o modelo proposto por Le Corbusier e direcionava boa parte da produção de arquitetura moderna no Brasil.

Tendo trilhado caminhos mais plásticos, seu início de carreira foi marcado por soluções formais arrojadas quando comparado aos seus trabalhos posteriores. O desdobramento do módulo e das medidas sobre o espaço ocorria mais claramente no interior das edificações do que nas fachadas. A geração da forma estava mais pautada pelo programa do que pela razão estrutural e a implantação visava uma articulação de blocos formalmente distintos entre si. Este modo de pensar arquitetura pode ser observado em seus projetos até meados da década de 1950. Entretanto, muitos dos princípios projetuais que vieram a nortear a sua produção já vinham sendo materializados. A lógica estrutural concisa e o rigor modular eram claramente presentes nos seus edifícios. 


\section{Amadurecimento e rigor construtivo}

"No momento em que as críticas dos positivistas curitibanos contra a arquitetura de Niemeyer iam se transformando em exotismos distantes da realidade, as concepções dos arquitetos cariocas passaram a ser contestadas por engenheiros-arquitetos como Rubens Meister. (...) Em meados dos anos 1950, a influência carioca chegou ao máximo entre os engenheiros-arquitetos de Curitiba, para logo se esvanecer. (...) Os profissionais curitibanos admiravam a arquitetura carioca e só. A família de Artigas mantinha-se em Curitiba; Elgson Ribeiro Gomes estava trabalhando com Franz Heep; o engenheiro-arquiteto Rubens Meister, propagandeava o amigo Rino Levi como um dos profissionais 'mais corretos' da arquitetura no Brasil. Cada vez mais, nas lides cotidianas, as obras de arquitetos

como Niemeyer ou Bernardes pareciam utopias, e o ponto de referência dos profissionais de Curitiba era a arquitetura produzida

em São Paulo".

(DUDEQUE, 2001, p. 218-220)

Somado ao constante aperfeiçoamento prático, a compreensão de perspectivas teóricas oriundas da Bauhaus cada vez mais se solidificavam ao repertório de Rubens Meister. As obras realizadas pelos arquitetos europeus em solos estadunidenses nutriam o horizonte intelectual de boa parte dos arquitetos brasileiros, e com Meister não foi diferente.

No projeto da antiga Rodoviária de Curitiba (1956) (figura 13), na antiga Praça Senador Correia, centro da cidade, a modulação ortogonal em um único e comprido bloco se fazem
Figura 13 (nesta página, abaixo): Rodoviária de Curitiba (1956). Fonte: Acervo do autor

Figura 14 (na outra página, acima): Bloco da Administração do Centro Politécnico (1956). Fonte: Acervo do autor.

Figura 15 (na outra página, abaixo) Implantação do Centro Politécnico (1956). Fonte: Google Earth. Acesso em 24.dez.2019 e editado pelo autor.

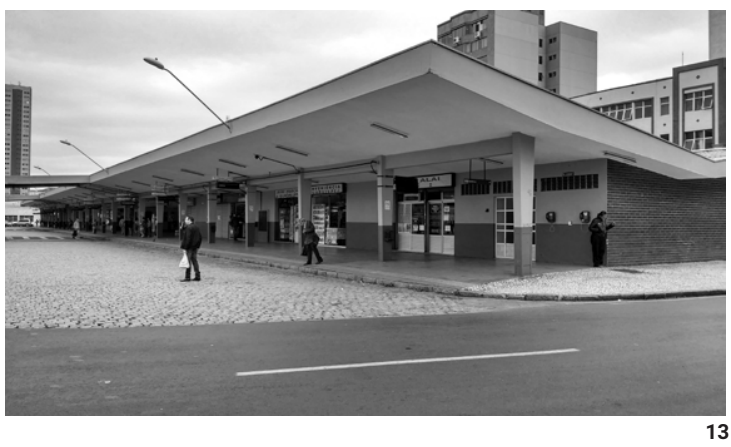




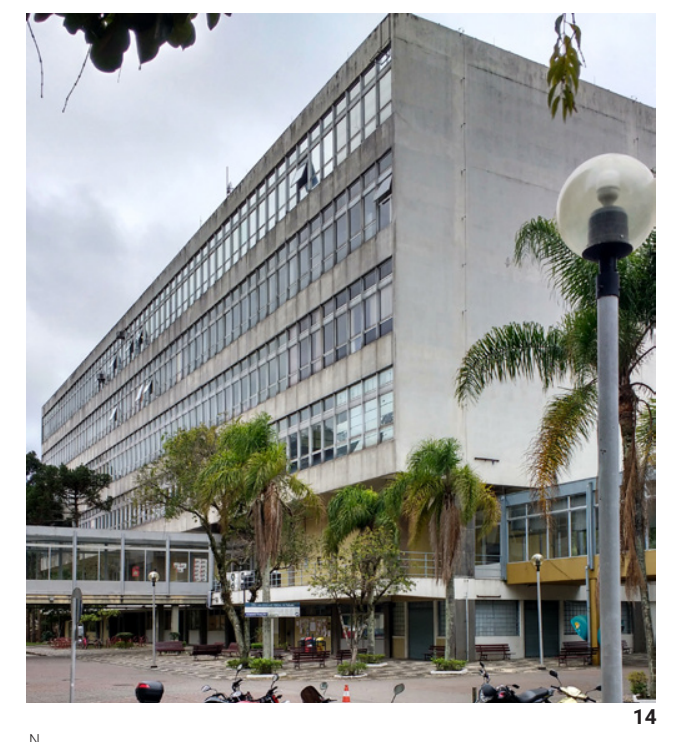

(N)

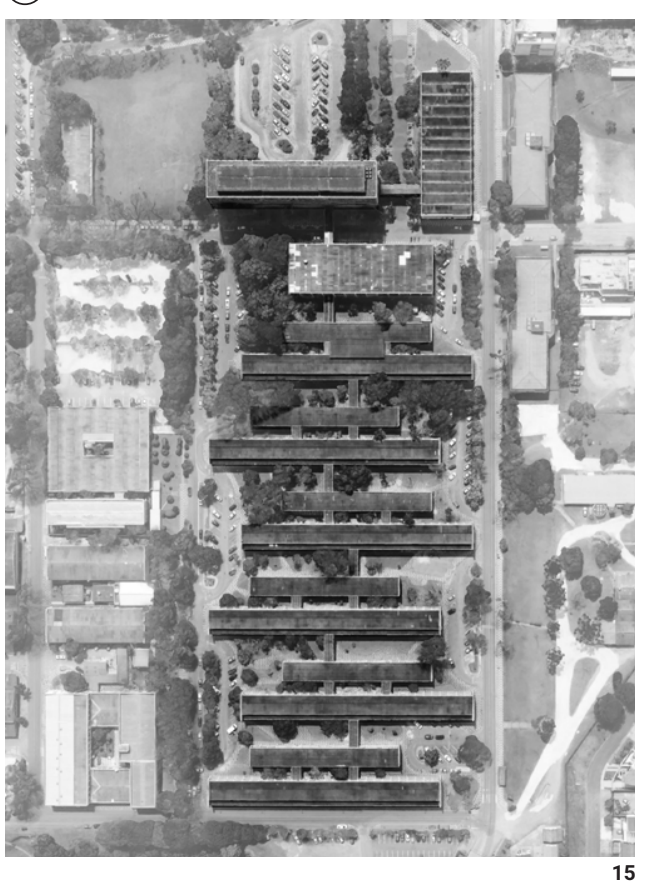

necessárias tendo em vista o sítio de inserção e as atividades inerentes a uma rodoviária. É válido destacar aqui a regularidade na distribuição dos usos e acessos, os quais configuram uma planta simétrica e funcional. Contudo, determinadas soluções ainda remetem a ecos da arquitetura carioca: o telhado em "borboleta" e as duas marquises de acesso com curvas abertas (demolida posteriormente). Hoje o local funciona como um terminal urbano de transporte público, o Terminal Guadalupe.

Aos poucos, a plasticidade do concreto ia dando espaço a concepções e aplicações mais regulares na construção dos seus projetos. Isso pode ser observado no seu terceiro projeto para a Universidade Federal do Paraná, o Centro Politécnico (1956) (figuras 14, 15 e 16) no bairro Jardim das Américas. O complexo, composto por seis lâminas duplas (blocos didáticos), um bloco de biblioteca, um de administração, um de salão de provas, um de laboratórios, três para o departamento de arquitetura e um de auditório, somava mais de 40.000,00 m². Os dois últimos não foram construídos. A disposição da implantação indica pressupostos utilizados nas escolas de arquitetura moderna da Europa e Estados Unidos. As aberturas na cobertura inclinada potencializam a luz natural no interior das salas de aula bem como a geração dos pátios internos que distanciam os blocos. Estas soluções podem ser observadas em projetos como a Munkegaard School na Dinamarca (Arne Jacobsen, 1948). Segundo o arquiteto Salvador Gnoato, "o Centro Politécnico foi inspirado no Illinois Institute of Technology IIT (1939-1958), em Chicago, de Mies. O conjunto de edificações localizado em um vasto terreno afastado da malha urbana, adotou semelhante proposta de implantação de blocos, dentro do espírito funcionalista dos CIAMs." (GNOATO, 2009, p.118).

Além do projeto do Centro Politécnico, Meister presidiu a comissão de criação do então aguardado Curso de Arquitetura e Urbanismo da Universidade Federal do Paraná em 1956. A inauguração da primeira turma se deu em 1962 sendo que Meister estabeleceu atividade docente até 1979 recebendo, um ano depois, o título de professor emérito (CARVALHO; BATISTA; CHIESA, 2019, p.69). 


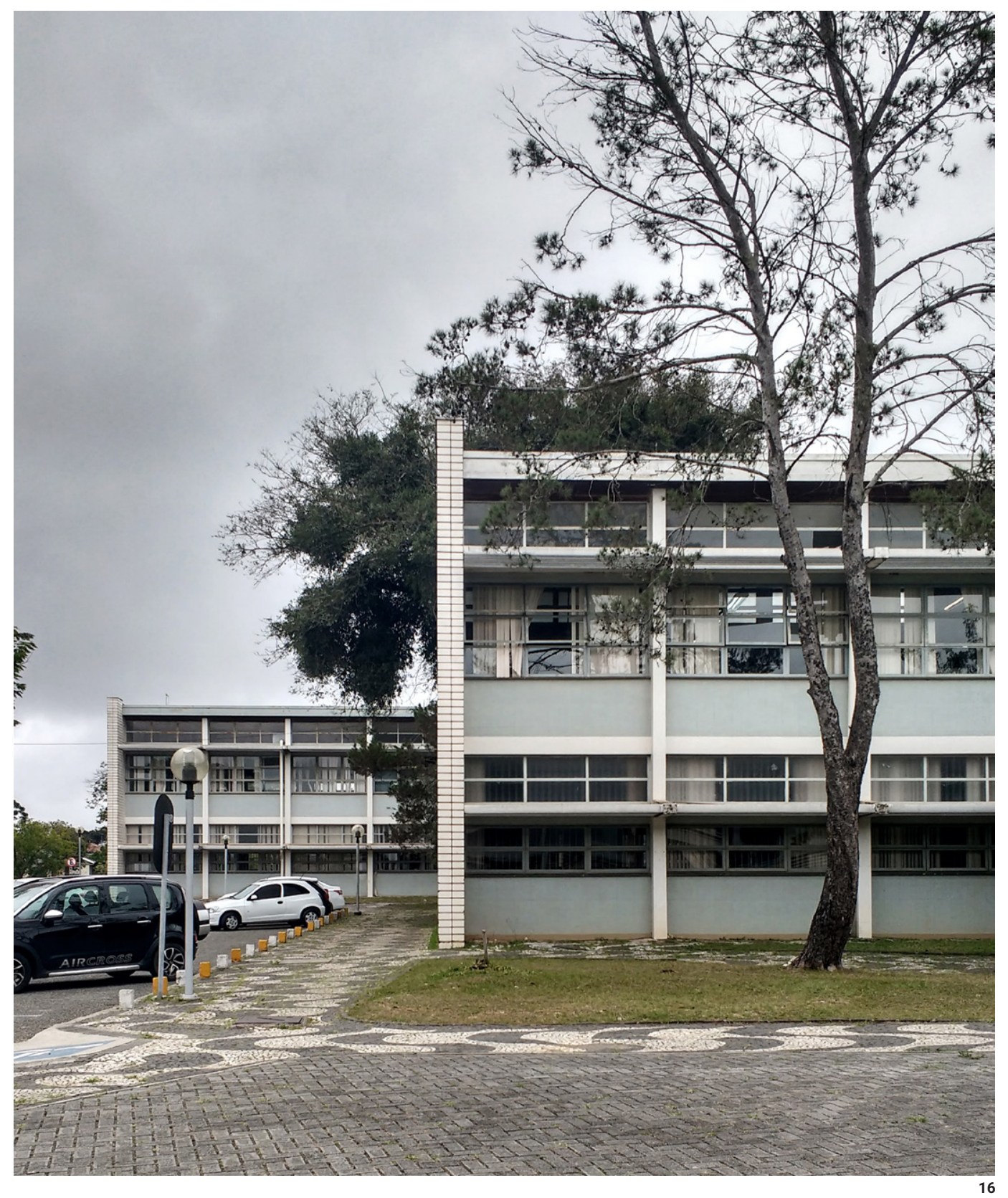



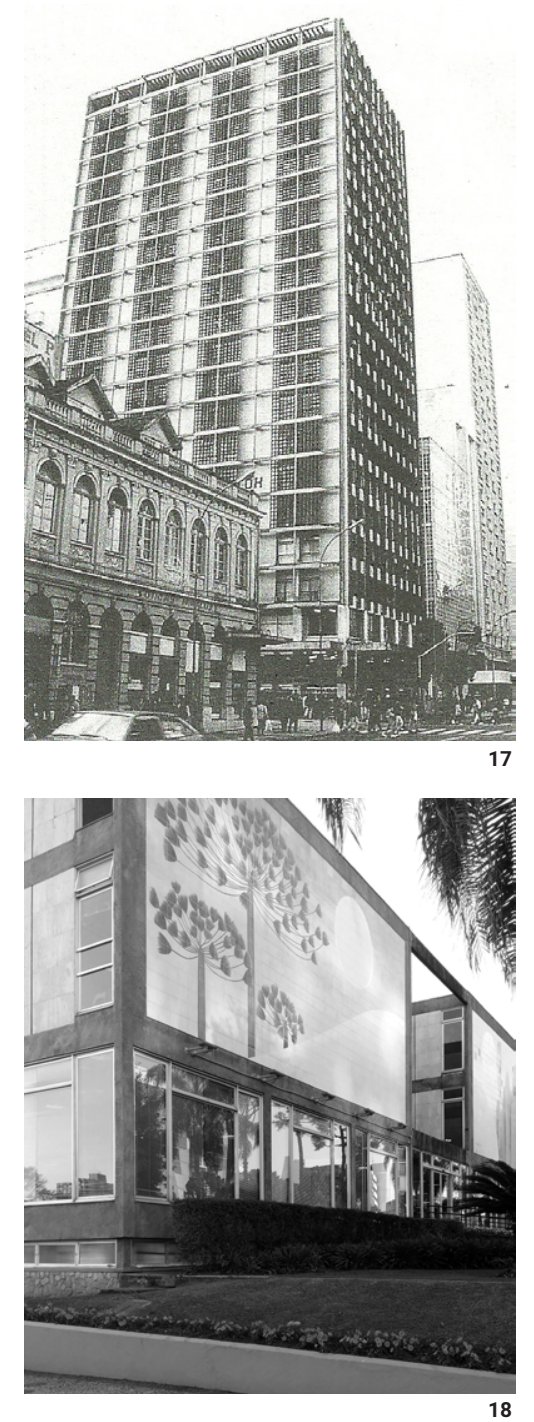

Figura 17 (acima): Edifício Barão do Rio Branco (1958). Fonte: SUTIL;GNOATO, 2005, p.32.

Figura 18 (abaixo): Palácio 29 de Março (1960). Fonte: Acervo do autor.
A partir de meados da década de 1950, novos programas emergentes começaram a delinear a nova cara de Curitiba. Grandes edifícios de usos comerciais, institucionais e residenciais "riscaram os céus" da capital paranaense através de uma verticalização progressiva das áreas centrais. Todavia, neste momento as construções modernas adquiriram protagonismo fora do poder público. "Na segunda metade dos anos 1950, a arquitetura passou também a angariar os pontos publicitários de Curitiba" (DUDEQUE, 2001, p. 217). Em 1958, uma parceria entre Meister e o arquiteto Salvador Candia ${ }^{15}$, que possuía escritório sediado em São Paulo, resultou em um edifício de uso misto no centro de Curitiba, o Barão do Rio Branco (figura 17). 0 prédio de 22 andares, situado na importante esquina das Ruas Barão do Rio Branco e Marechal Deodoro, foi concebido dentro de uma malha ortogonal regular em que os núcleos de circulação e prumadas hidráulicas favoreciam a flexibilidade da planta

No final dos anos 1950, as demandas por espaço físico levaram a Prefeitura Municipal de Curitiba a pensar na sua nova sede. Em 1960, Rubens Meister projetou o Palácio 29 de Março ${ }^{16}$ (figura 18) em um terreno agregado ao Centro Cívico do Estado do Paraná (1951), na Avenida Cândido de Abreu. O projeto reúne diversos aspectos recorrentes na obra de Meister, sendo que a sua expressão arquitetônica resulta do desdobramento do módulo estrutural. Nesta mesma avenida, a algumas quadras de distância, foi convidado em 1962 a desenvolver os estudos para o Edifício Lydio Paulo Bettega (FIEP) (figuras 19 e 20) que incluía um bloco de escritórios, teatro e ginásio de esportes. Implantado de forma semelhante ao projeto completo do Palácio 29 de Março, o complexo possuía uma torre mais alta transversal à Avenida Cândido de Abreu e um bloco mais baixo e retangular (referente ao auditório) concorrente à torre. Projetou no mesmo ano o Edifício Avenida (1962) (figuras 21, 22 e 23), de uso comercial, em um pequeno lote que cruzava o caminho do Rio Ivo, na esquina da Rua Ébano Pereira com a Luiz Xavier (pequeno prolongamento da Rua XV de Novembro). A torre, de 20 pavimentos, contém os núcleos de 

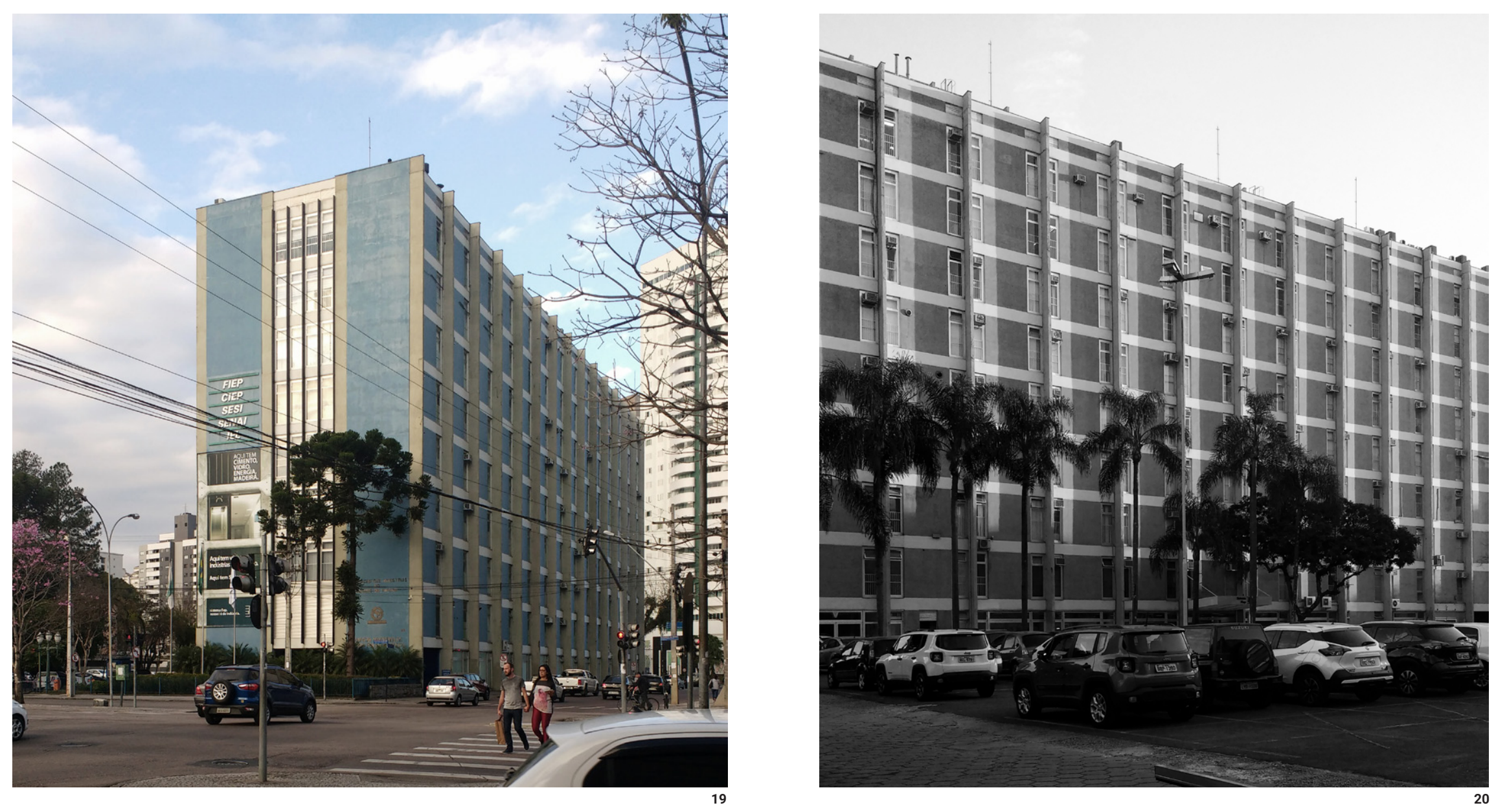

Figura 19 (nesta página à esquerda):

Edifício Lydio Paulo Bettega/FIEP (1962)

Fonte: Acervo do autor

Figura 20 (nesta página à direita): Edifício

Lydio Paulo Bettega/FIEP (1962). Fonte

Acervo do autor.

Figura 21 (na próxima página): Edifício

Avenida (1962). Fonte: Acervo do autor 


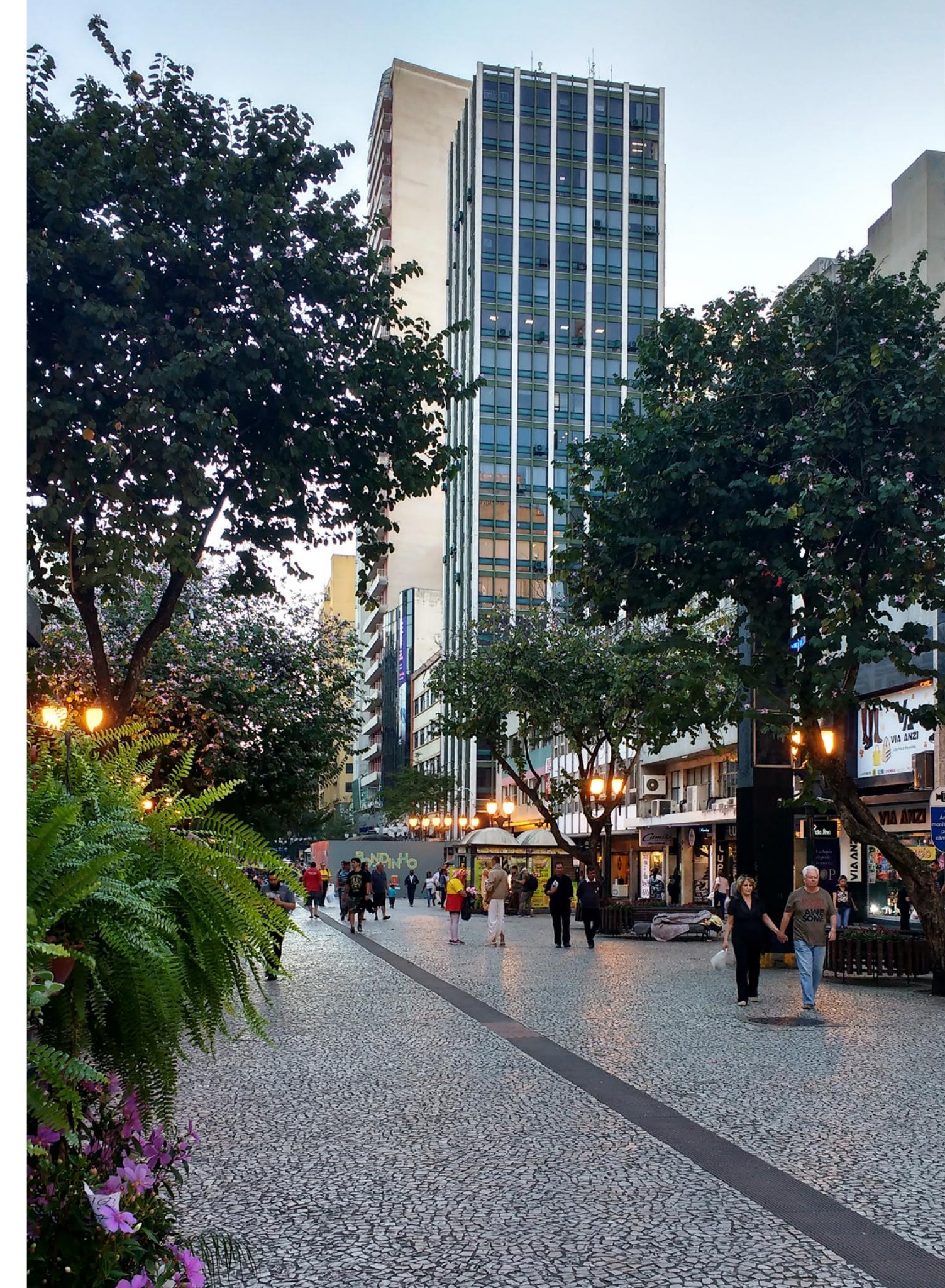



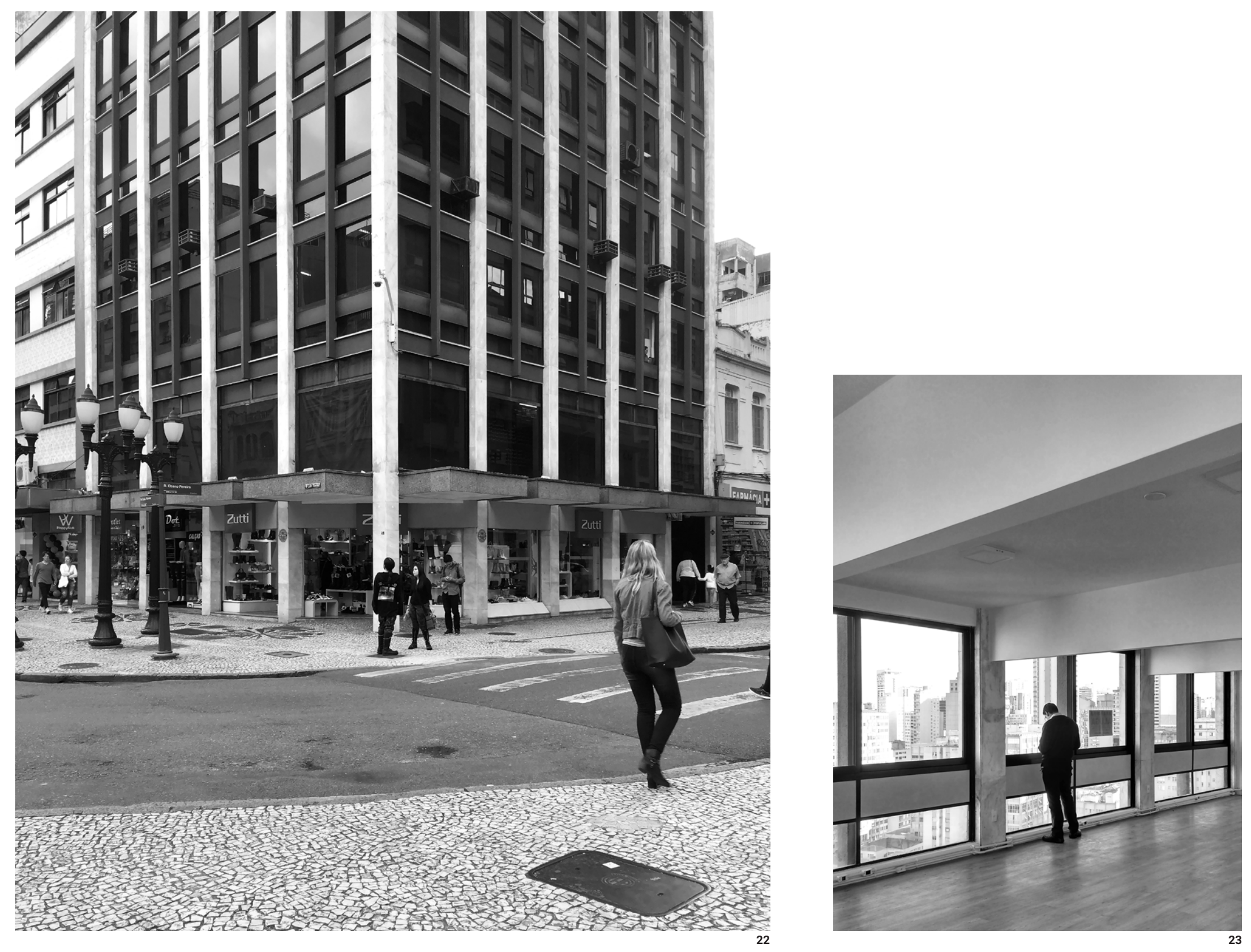

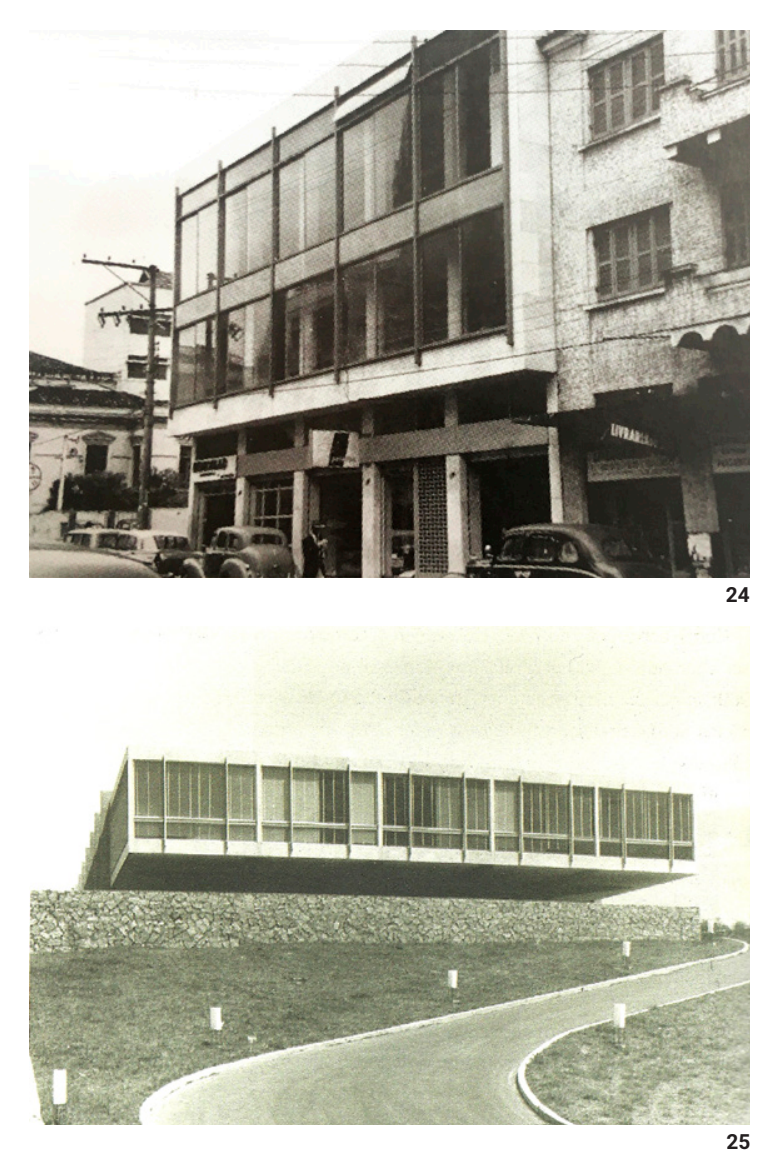

Figura 22 (na página anterior, à esquerda): Esquina do Edifício Avenida (1962). Fonte: Acervo do autor.

Figura 23 (na página anterior, à direita): Interior de uma das salas do Edificio Avenida (1962). Fonte: Acervo do autor.

Figura 24 (nesta página, abaixo): Sede do IEP (1953). Fonte: CARVALHO; BATISTA; CHIESA, 2019, p. 71

Figura 25 (nesta página, acima): Sede da Celepar (1964). Fonte: GNOATO; SUTIL, 2005, p. 78. circulação e de prumadas hidráulicas voltadas aos fundos do terreno, liberando as plantas livres das salas para as esquinas. Os módulos estruturais são comunicados continuamente na fachada através dos pilares externos. Revestidos em mármore branco ante ao verde escuro da caixilharia e parapeitos, eles fortalecem, dessa maneira, a verticalidade do edifício.

Entre os anos de 1963 e 1965, Rubens Meister presidiu o Instituto de Engenharia do Paraná (IEP). O projeto da sede também é de sua autoria e data de 1953 (figura 24).

O rigor modular aparecia cada vez mais como uma potencialidade expressiva nas obras de Meister. Mesmo se utilizando de uma tecnologia muito menos sofisticada industrialmente que suas principais referências estrangeiras, seu grande repertório técnico possibilitava a concepção de artefatos arquitetônicos genuínos e de apelo estético. A Sede do Centro de Processamento de Dados do Paraná (Celepar) (1964) (figura 25) traz elementos da modernidade norte-americana à sua principal fachada. Os perfis verticais externos às esquadrias dividem o plano de modo que um quarto da dimensão (do plano) limita-se com o módulo estrutural e metade dela posicione-se ao meio. Essas relações de proporção no desenho da caixilharia foram amplamente utilizadas por Meister desde o Teatro Guaíra (1948-1951) até o final dos anos 1960. Os pilares e vigas são soltos da edificação, envolvendo o volume como num pórtico em meio às esquadrias e alvenarias em tijolos maciços aparentes. O bloco, pousado no ponto mais alto do terreno, parece flutuar sobre um baixo muro em pedras (que escondia o estacionamento) o qual reforça a soltura do balanço estrutural.

Meister, no final dos anos 1960, apresentou um conjunto de novos marcos arquitetônicos em Curitiba. O Edifício Atalaia (1967) (figuras 26 e 27), na esquina oposta ao Edifício Barão do Rio Branco (1958), ergue-se em 21 pavimentos de escritórios aos moldes do Edifício Avenida (1962) localizado em um terreno central de esquina e pequeno, sendo que os pilares externos à fachada ganham protagonismo tanto pela continuidade, quanto pelo contraste do seu revestimento em mármore branco ante à pintura escura do sistema de esquadrias dispostas entre os módulos estruturais da fachada. O núcleo de circulação vertical é posicionado ao centro da planta e 


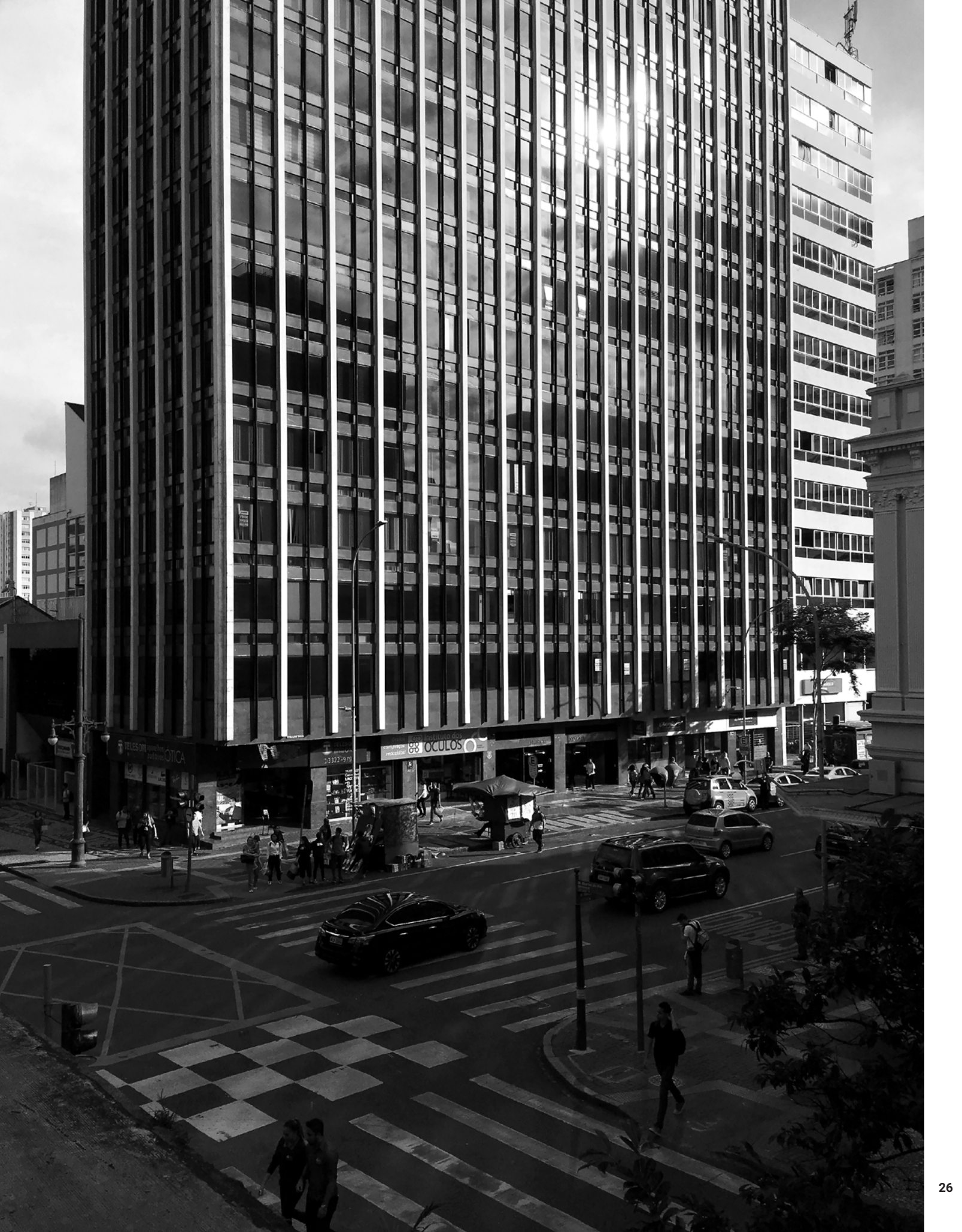



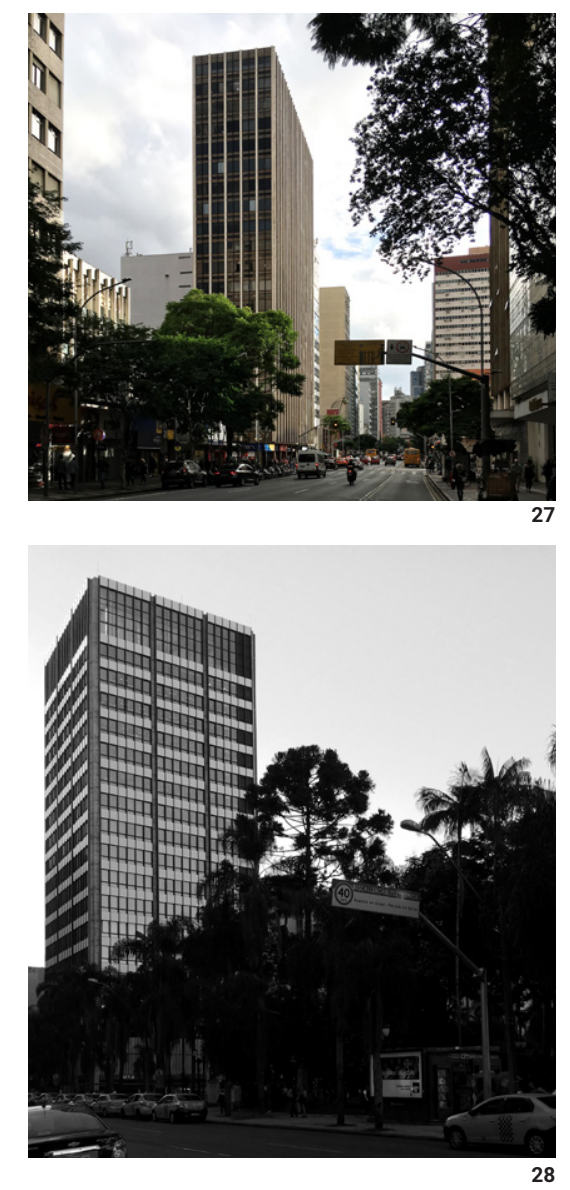

Figura 26 (na página anterior): Edifício Atalaia (1967) a partir do Edifício Barão do Rio Branco (1958). Fonte: Acervo do autor. Figura 27 (nesta página acima): Edifício Atalaia (1967). Fonte: Acervo do autor. Figura 28 (nesta página abaixo): Edifício Sede da Caixa Econômica Federal (1967) Fonte: Acervo do autor.

Figura 29 (na página seguinte): Edifício Sede da Caixa Econômica Federal (1967) Fonte: Acervo do autor fundos do estreito lote, de modo que possa liberar o máximo possível de fachada para as salas comerciais.

O célebre edifício da sede da Caixa Econômica Federal (1967) (figuras 28, 29 e 30), localizado em frente à Praça Carlos Gomes, foi concebido em 21 andares, sendo que dois deles compõem um embasamento que foge à projeção da torre quadrada (assim como os subsolos) e ocupa todo o lote. As circulações verticais (compostas por um núcleo central de escadas e seis elevadores), instaladas na face leste, simetricamente à planta tipo, mantêm esta fachada "cega". A torre é conformada em uma rigorosa malha quadrangular de pilares (quatro por quatro) modulados a cada 8,125 metros. A medida de 7,50 metros entre eles (face a face) desdobra-se à fachada a partir dos montantes que dividem as seis esquadras de 1,25 metros de largura cada. O tratamento dado às esquinas nesta edificação é digno de nota: o pilar em concreto armado aparente é assumido como uma aresta levemente recuada do sistema de fachada modular. A solução (bem como a dada ao coroamento que compõe o auditório) assemelha-se à dada por Mies van der Rohe em muitos de seus edifícios em altura.

Cabe aqui ressaltar a afirmação da presença da arquitetura Mies em seus edifícios mesmo considerando a difícil transposição para a artesanal construção civil do país. Os prédios de alto gabarito talvez sejam os que possuem maior facilidade de transparecer esta informação tendo em vista os critérios adotados: a implantação, a modulação, a fachada uniforme, a estrutura da caixilharia externa, as quinas que revelam os pilares e os coroamentos. Meister mostrava-se atento às obras do mestre especialmente em sua fase norte-americana, a partir do II pós-guerra. Em uma visita ao Edifício Seagram (Mies van der Rohe, 1954), em Nova lorque, relatou:

"O projeto estabelece rigorosa modulação entre estrutura de aço, as esquadrias, a paginação do piso de mármore e do forro; em todas as dimensões do edifício, incluindo o elevador." (MEISTER, 1995 apud SUTIL; GNOATO, 2005, p. 10) 

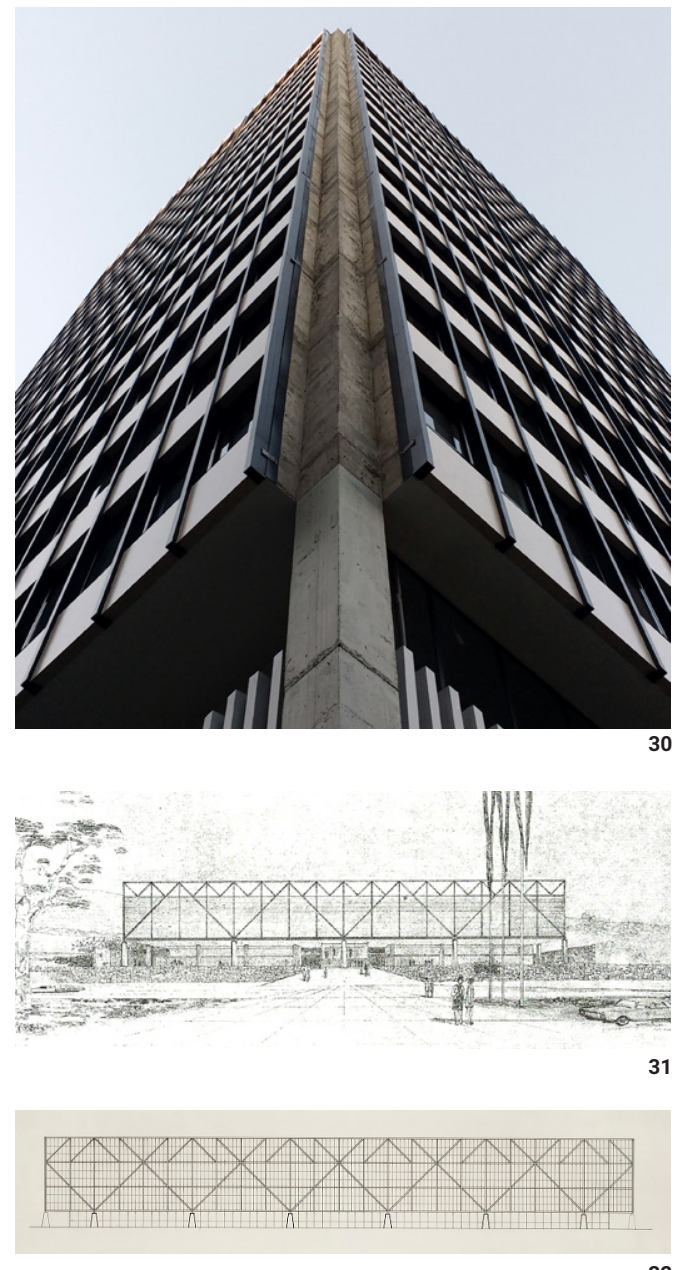

Figura 30: Esquina do Edifício Sede da Caixa Econômica Federal (1967). Fonte Acervo do autor.

Figura 31: Pavilhão Expoville (1967)

Fonte: Acervo Rubens Meister

Figura 32: Chicago Convention Hall

(1953). Disponivel em: < http://www.

moma.org>. Acesso em: 18.jan.2019
A observação de Meister vai além de uma simples análise de uma obra de Mies, ela é um princípio que guiou o seu pensamento arquitetônico e de muitos outros arquitetos modernos. Os ideais da racionalização da construção permeavam seus projetos nas mais diversas escalas. Entretanto, ainda engatinhava a indústria brasileira possuindo insuficiente abastecimento para os pressupostos da arquitetura moderna nos anos 1950 e 1960. Frente a essa realidade, os arquitetos brasileiros buscavam alternativas a partir das tecnologias disponíveis. 0 ainda tímido processo de industrialização permitiu, no entanto, o desenvolvimento dessa nova arquitetura sem necessariamente desvinculá-la de seu valor artístico. Sobre este aspecto, é importante destacar um projeto fora de Curitiba, o Pavilhão da Feira de Amostras de Santa Catarina (Expoville) (1967) (figura 31) de Joinville, e relacioná-lo ao Chicago Convention Hall (Mies van der Rohe, 1953) (figura 32): a estrutura da treliça como expressão plástica é muito semelhante entre os projetos. Os pontos de apoio em concreto são arrematados nas quinas da edificação no Pavilhão da Expoville, enquanto Mies os recua meio módulo estrutural, onde faz o arranque da treliça. Em seus estudos, Mies veda o pavilhão, entre os perfis das treliças, com dois tipos de mármores. Meister fecha-os com uma trama intercalada em dois sentidos de tijolos maciços e aparentes.

A funcionalidade de seus projetos assim como a classificação dita racionalista não embute necessariamente ao artefato uma redução de valores alheios à sensibilidade e juízo estético. Como salienta Segawa (2012, p. 46), ao falar sobre o rigor técnico da obra do arquiteto Oswaldo Bratke: "Não se pode associar a sua obra ao radicalismo da pura técnica, mas entender que a técnica apurada tem o seu potencial expressivo". Sob diferentes formas, o valor universal destas obras também é reforçado a partir das suas coerentes adaptações modernas às realidades e culturas locais, o que Ihes conferem "sentido e consistência", como afirma Hélio Piñón:

"Ao se tratar de identificar e reconhecer os atributos que garantem qualidade da obra de arte - sentido e consistência - aparece 
como inevitável a noção de juízo estético, ação que não deve ser entendida como sanção ou qualificação do objeto por parte de uma autoridade indiscutível, senão como reconhecimento dos atributos formais e culturais que Ihe conferem identidade. (...) Essa identidade

é o resultado da síntese dos requisitos do programa, do sistema construtivo e dos critérios estéticos que oferece a história, por meio

da forma."

(PIÑÓN, 2006, p.84)

Outro ponto importante é o sentido urbano dos edifícios em altura de Meister, desde a sua relação com o solo urbano à sua presença na paisagem. As torres, concebidas a partir da adoção de índice de aproveitamento do solo alto, foram tratadas como um volume prismático puro (no caso dos projetos apresentados, apenas o Edifício Lydio Paulo Bettega não se encontra em um lote exíguo). O contato com o chão é claro e sem "alardes", ou seja, os acessos e as barreiras entre o público e privado são bem definidos, estando geralmente limitados próximos à projeção da edificação.

Nos mesmos moldes que havia realizado na Rodoviária de Joinville (1968), Meister projetou a Estação Rodoferroviária de Curitiba (1969)17 (figura 33) que viria a suprir a demanda da antiga, também de sua autoria. O constante aperfeiçoamento e raciocínio projetual do engenheiroarquiteto pareceu apontar para o desenvolvimento de um vocabulário próprio no final dos anos 1960, o qual foi, em certa parte, atribuído ao complexo de 32.000,00 m² e que resultou em um de seus projetos mais expressivos e reconhecidos pelos estudiosos de sua obra.

A Agência do Banco Bamerindus (1969) (figuras 34 e 35), localizada na esquina da Rua XV de Novembro com a Avenida Marechal Floriano Peixoto, é mais uma edificação que demonstra a importância de Rubens Meister no cenário urbano construído da capital paranaense mesmo
Figura 33 (acima): Rodoferroviária de Curitiba (1969). Fonte: Acervo do autor.

Figura 34 (abaixo): Agência do Bamerindus (1969) . Fonte: Acervo do autor.
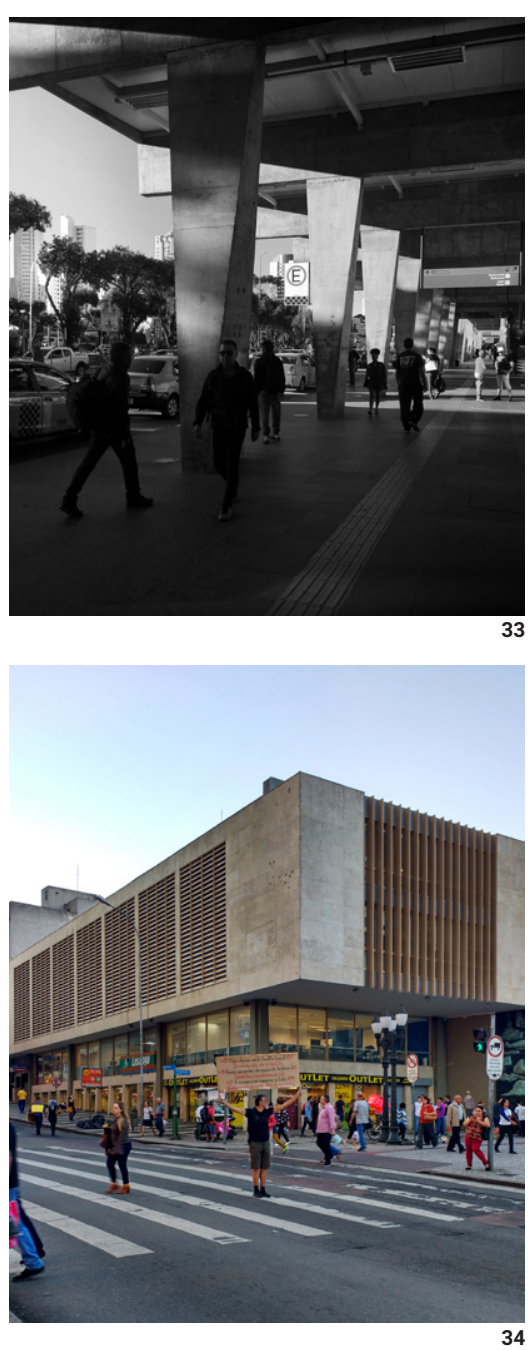


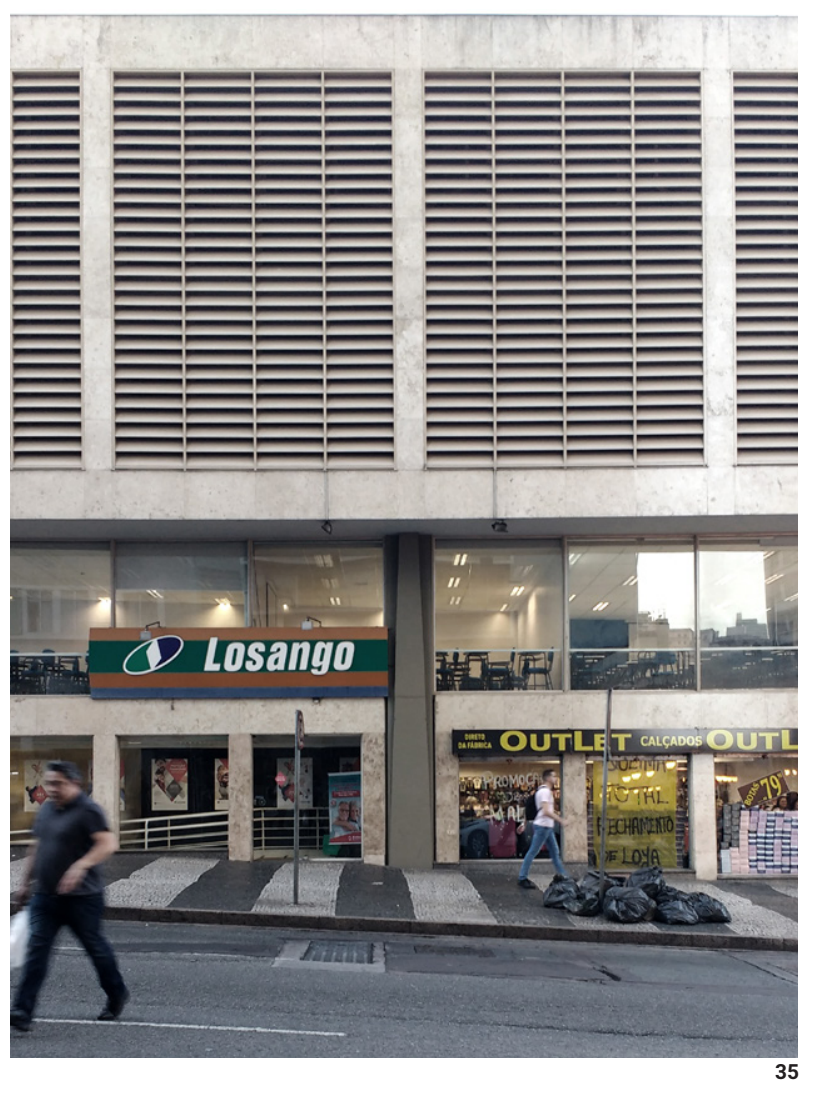

Figura 35: Agência do Bamerindus (1969)

Fonte: Acervo do autor: que em um edifício baixo. O volume puro dos dois últimos andares se apresenta como uma massa (paginada pelo mármore travertino que reveste a fachada) que se apoia sobre pilares com secção em cruz, os quais ampliam-se e adquirem secção de um quadrado regular ao toca o solo. A reverberação das medidas na fachada é mais discreta nos dois últimos pavimentos da agência e o destaque vai para a expressividade plástica dos elementos que compõem o térreo e o $1^{\circ}$ pavimento

Estes dois últimos projetos trazem à tona o período de transição que estava por se desenrolar no pensamento arquitetônico de Meister. O modo como trabalhou a visualidade da estrutura, a manipulação e relação entre os materiais evoca um olhar direcionado a um novo horizonte arquitetônico. 


\section{Uma arquitetura moderna e orgânica}

"Naturalmente precisamos evoluir e os projetos de hoje se diferenciam das fases anteriores. A tendência, penso ser mais no

sentido orgânico e de diversificação." (MEISTER in ZEIN, 1986, p.43)

A partir da criação do Curso de Arquitetura e Urbanismo (CAU) da UFPR em 1962 e a chegada de profissionais de diferentes partes do Brasil para compor o quadro de docentes, algumas transformações aconteceram no cenário arquitetônico de Curitiba. O brutalismo e a arquitetura paulista passaram a exercer grande influência no cenário paranaense. Meister, apesar de cada vez mais ter se utilizado dos materiais em sua forma natural nas obras, acabou sendo um dos profissionais que buscou se distanciar dessas linguagens. Conforme passava a década de 1970, seus projetos se mostravam cada vez menos parecidos com os exercidos pelos novos profissionais situados em Curitiba, conhecidos como Grupo do Paraná18.

"Não me agradava a ideia brutalista de expor as entranhas dos edifícios, as tubulações, os encanamentos. Meu argumento era simples. Se Deus fosse brutalista, estaríamos com as artérias, as tripas e os miolos à mostra. Mas Deus nos fez simétricos e pegou toda aquela confusão do corpo humano e fez uma composição 


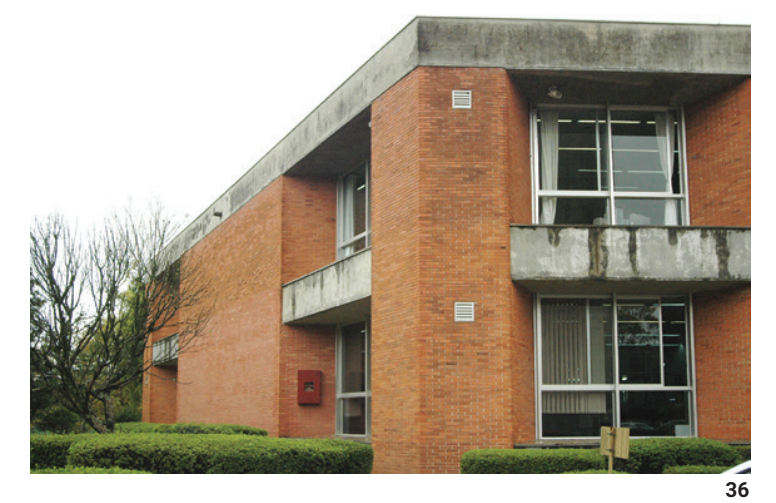

simétrica. Então eu acho que o revestimento é, às vezes, necessário."

(MEISTER, 1995 apud SUTIL; GNOATO, 2005, p. 10)

Em 1972, associou-se ao arquiteto uruguaio Elias Lipatin Furman. Foi por volta deste momento que Meister começou a trabalhar naquilo que veio a ser uma mudança estrutural em sua arquitetura"19 segundo Salvador Gnoato: "uma aproximação maior com Frank Lloyd Wright" (SUTIL; GNOATO, 2005, p.83). Esteve atento à questões que fugiam ao meramente figurativo, por exemplo, ao utilizar amplamente o módulo triangular como base da estrutura, traço que Meister adotou pela primeira vez no projeto para a Vila Residencial de Itaipu de 1974 (CARVALHO; BATISTA; CHIESA, 2019, p.303) no lugar da malha ortogonal, inerente à sua obra até então.

O material "à mostra", sem revestimento, passou a assumir um protagonismo visual em suas edificações, sendo utilizado de forma criteriosa e respeitosa às diferentes funções.

"Para resolver meus edifícios, observo a natureza. Se uma parede é de pedra, não precisa de proteção, porém existem casos em que o revestimento é necessário. Se uma árvore tem cerne mole, sua casca é grossa; por outro lado, se o cerne é duro, sua casca é fina.

Deus não fez o homem com seus intestinos à mostra". (MEISTER, 1995 apud SUTIL; GNOATO, 2005, p.10)

A leveza proporcionada por soluções de projetos que se utilizam de juízos visuais modernos, a abstração pautada pela lógica construtiva, a modulação refletida na composição da fachada e a clareza da solução estrutural - amplamente vistas na arquitetura moderna dos anos 1950 - 
deixaram de sintetizar uma estética em Meister. Passaram a ser substituídas por outros critérios, o que resultou em uma nova expressão arquitetônica: houve uma valorização da matéria e Meister passou a utilizar como volume - ou massa - na resultante plástica do artefato, e não mais no delineamento dos planos.

Os arquétipos de formas puras desmembraram-se de uma unidade regular e passaram a adquirir tipologias mais variadas, com blocos hexagonais por vezes juntos a blocos retangulares. Estes, como pode-se observar em edifícios como a Sede Administrativa do Banco Banestado (1975) (figura 36) e o Sesc da Esquina (1980) (figuras 37 e 38), tornaram-se menos definidos em proporção e clareza da forma. As esquinas não eram mais locais de expressão dos pontos de apoio e de diferenciação entre as soluções estruturais e vedações externas. Em muitos casos passaram a obter soluções que suavizam as arestas através do módulo triangular, o qual gerava ângulos de 120 graus, e estavam associados à utilização de materiais aparentes como o bloco cerâmico maciço e no tratamento cauteloso de sua paginação. Os núcleos de circulação vertical e infraestruturas passaram a buscar formas fora da edificação, como um corpo independente, seguindo os princípios do beat the box ${ }^{20}$, de Wright. Quando não deslocadas, a estas peças atribuiu-se algum destaque que identificava o seu uso.

Apesar da grande quantidade de projetos que envolviam o seu escritório, esta foi a fase em que Rubens Meister menos esteve à frente de obras que se consolidaram como referência no cenário urbano de Curitiba. A última consistiu na Readequação do Palácio Avenida (1985), na Rua XV de Novembro, em que o projeto esteve limitado a uma reforma na porção interna do edifício, o qual abrigou a sede do Banco Bamerindus.

O menor envolvimento com obras públicas o manteve mais atrelado a projetos de residências particulares. Nestas, as soluções similares às propostas por Wright aparentavam

20 Beat the box - "superar a caixa" na tradução do autor - foi um termo utilizado por Frank Lloyd Wright ao tratar a forma com que trabalhou o núcleo de escadas fora da edificação, como um corpo livre e individual, no seu projeto para o Larkin Building (1906) e também no espaço contínuo da Robie House (1909). WRIGHT, Frank Lloyd. The Destruction of the Box, 1952 in KAUFFMAN, Edgar, Frank Lloyd Wright: Writings and Buildings. Plume, 1974
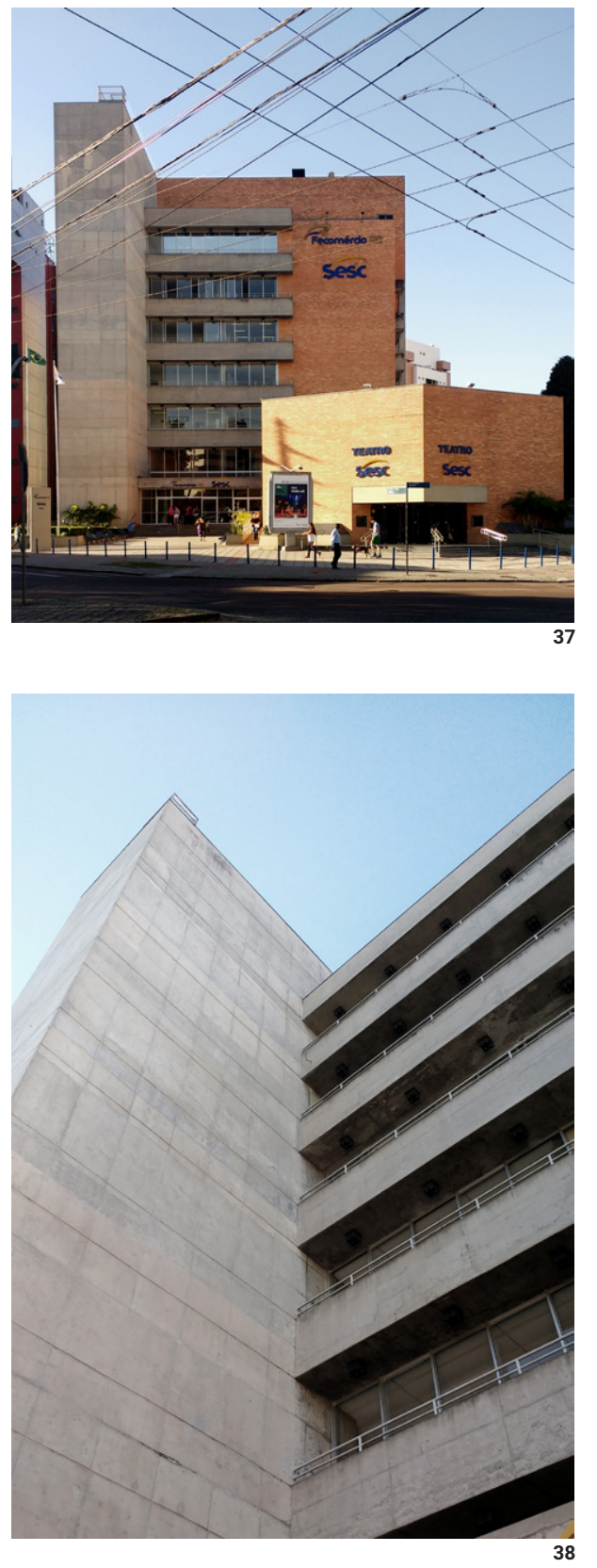


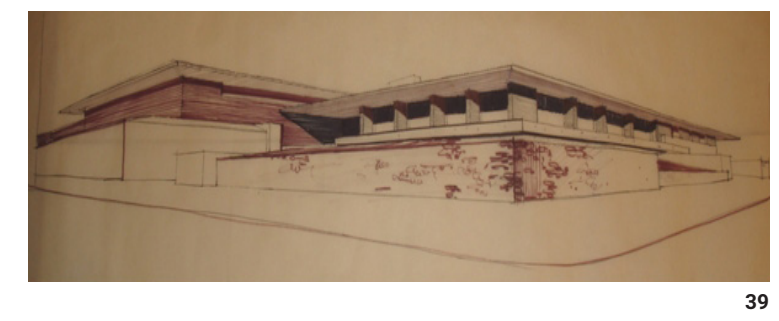

Figura 37 (na página anterior, acima): Seso da Esquina (1980). Fonte: Acervo do autor

Figura 38 (na página anterior, abaixo): 0 núcleo de circulação vertical no Sesc da Esquina (1980). Fonte: Acervo do autor.

Figura 39 (nesta página, acima): Estudo para a Casa Rosenmann (1974). Fonte Acervo Salvador Gnoato. ter uma grande aceitação estética pelos clientes: a cobertura em telhas cerâmicas, os tijolos maciços aparentes, o forro e caixilharia em madeira e os muros em pedras foram de utilização corriqueira em suas concepções (figura 39). Mas o que o conduziu nessa nova fase foi uma maior valorização da matéria e o reconhecimento dos vínculos entre arquitetura e natureza, sabedoria que lhe permitia evitar tentativas de reproduções estilísticas.

O Engenheiro-civil Rubens Meister trabalhou como arquiteto por aproximadamente 45 anos. Associando-se ao engenheiro Osiris Lepca, ao arquiteto Elias Lipatin Furman e com a constante colaboração do desenhista Erich Nissen, manteve seu escritório em funcionamento até o início da década de 1990. Além da prática, teve relação direta com o mundo acadêmico, sobretudo através da Universidade Federal do Paraná: estudou e graduou-se engenheiro, foi assistente de disciplinas após formado, sua obra mais importante - o Teatro Guaíra (1948-1951) - situa-se em frente ao prédio histórico da universidade, desenvolveu três projetos para a instituição, tornouse professor e foi o principal agente na criação do curso de Arquitetura e Urbanismo.

Anteriores a ele, as obras de Frederico Kirschgässner estabeleceram-se no prelúdio do movimento moderno paranaense e foram seguidas pelas pontuais realizações de Vilanova Artigas. Apesar de condutores dos primeiros manifestos, o pioneirismo do movimento, segundo Ruth Verde Zein (1986, p.40-47), compete a Meister . Como explicação, pode-se tomar os dizeres do arquiteto e historiador Carlos Lemos ao tratar do surgimento da modernidade paulista. Ele afirma que "o pioneirismo pressupõe uma sequência, um desenvolvimento, uma sucessão de ações influenciadoras, enfim, uma concatenação em cuja extremidade inicial se acha a matriz, o início do raciocínio, o elemento catalisador de uma série de ações em cadeia." (LEMOS, 1972).

A importância de Meister na construção de Curitiba foi além dos seus edifícios. Presidiu instituições, comissões e encabeçou atos em prol da arquitetura enquanto mantinha as atividades do escritório. Já afastado da profissão há alguns anos, continuou concedendo palestras e entrevistas, vindo a falecer no dia 29 de julho de 2009 em Curitiba, com 87 anos de idade. 


\section{Linha do tempo}

Currículo oficial de Rubens Meister e outros projetos que possuem informação de data.
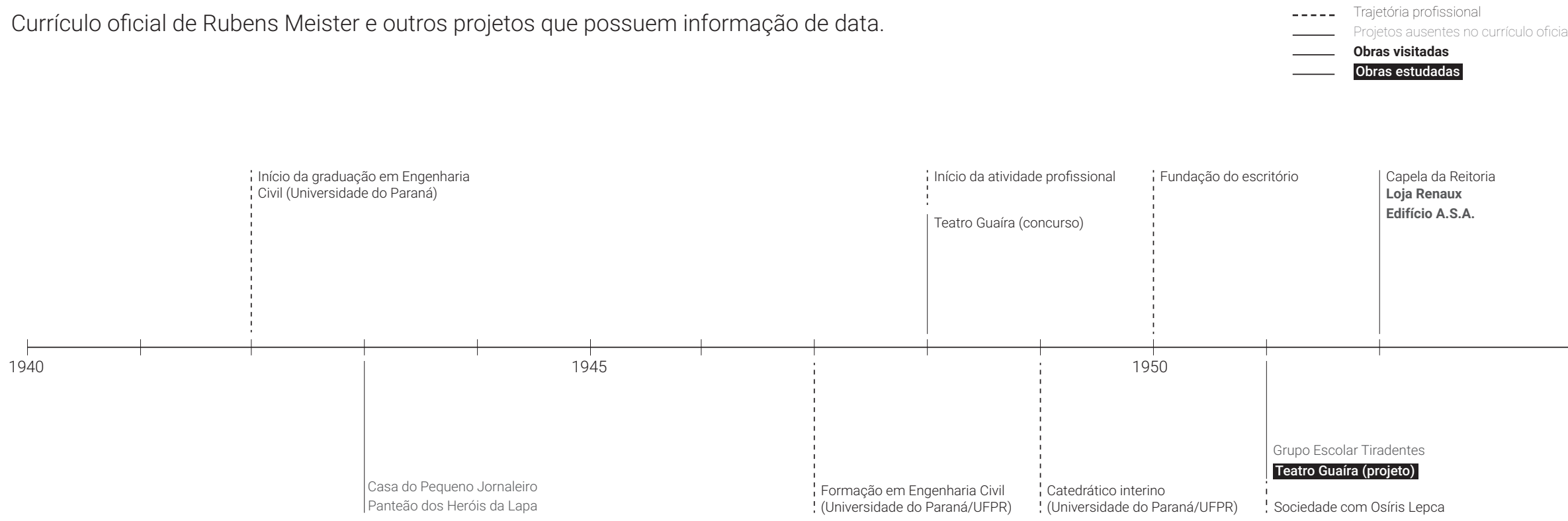

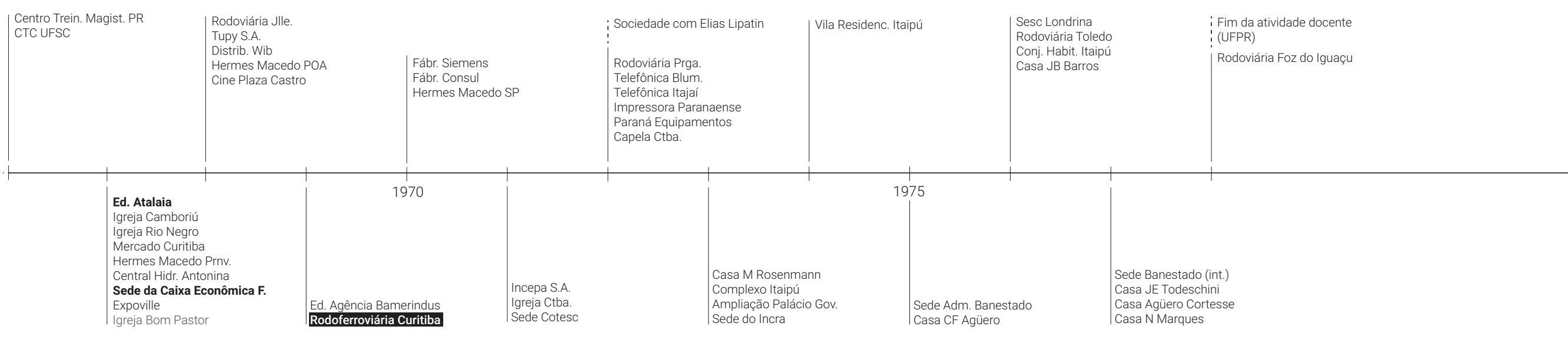




\begin{tabular}{|c|c|c|c|c|c|c|c|c|c|c|}
\hline | Inst. Eng. do PR & \multicolumn{2}{|c|}{$\begin{array}{l}\text { Presidência da Comissão } \\
\text { de criacãao do Curso de } \\
\text { Arquitetura da UFPR } \\
\text { Centro Politécnico UFPR } \\
\text { Rodoviária (Guadalupe) } \\
\text { Cine Hotel Colón }\end{array}$} & \multicolumn{2}{|c|}{\begin{tabular}{|l} 
Colégio em Rio Negro \\
Ed. Barão Rio Branco \\
Hermes Macedo Ctba \\
Móveis Cimo \\
Conj. Residencial \\
Casa L. Bório
\end{tabular}} & \multicolumn{2}{|c|}{\begin{tabular}{|l} 
Palácio 29 de Março \\
Olsen S.A. \\
Hermes Macedo Blum
\end{tabular}} & \multicolumn{2}{|c|}{$\begin{array}{l}\text { Hotel Curitiba } \\
\text { Ed. Lydio Bettega (FIEP) } \\
\text { Est. Figueira P. Grossa } \\
\text { Ed. Agência Villares } \\
\text { Hermes Macedo POA } \\
\text { Hermes Macedo P. Grossa } \\
\text { Ed. Avenida } \\
\text { Escritórios Ctba. } \\
\text { Cine Marrocos } \\
\text { Casa C. Schneider }\end{array}$} & \multicolumn{2}{|c|}{\begin{tabular}{|l} 
Paço Municipal de Toledo \\
Sede Celepar \\
Calfibra S.A. \\
Hermes Macedo CM \\
Mercado Ctba.
\end{tabular}} \\
\hline 195 & 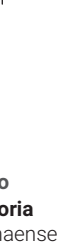 & \begin{tabular}{|l} 
Lumière \\
Ed. Mar
\end{tabular} & doro & \begin{tabular}{|l} 
Asso \\
Sena \\
Casa
\end{tabular} & La Lond. & $\begin{array}{l}\text { Conj. } \\
\text { Igreja }\end{array}$ & $\begin{array}{l}\text { Iguaçu } \\
\text { ell. }\end{array}$ & \begin{tabular}{|l} 
\\
\\
Forpasa \\
Igreja Cth \\
Catter Pil \\
' Presidên \\
? de Engen
\end{tabular} & $\begin{array}{l}\text { stituto } \\
\text { Paraná }\end{array}$ & \begin{tabular}{|l} 
Calfibra - Hidratador \\
Catter Pillar Lond. \\
Ag. Banestado Lond. \\
Vila Operadores Copel
\end{tabular} \\
\hline
\end{tabular}

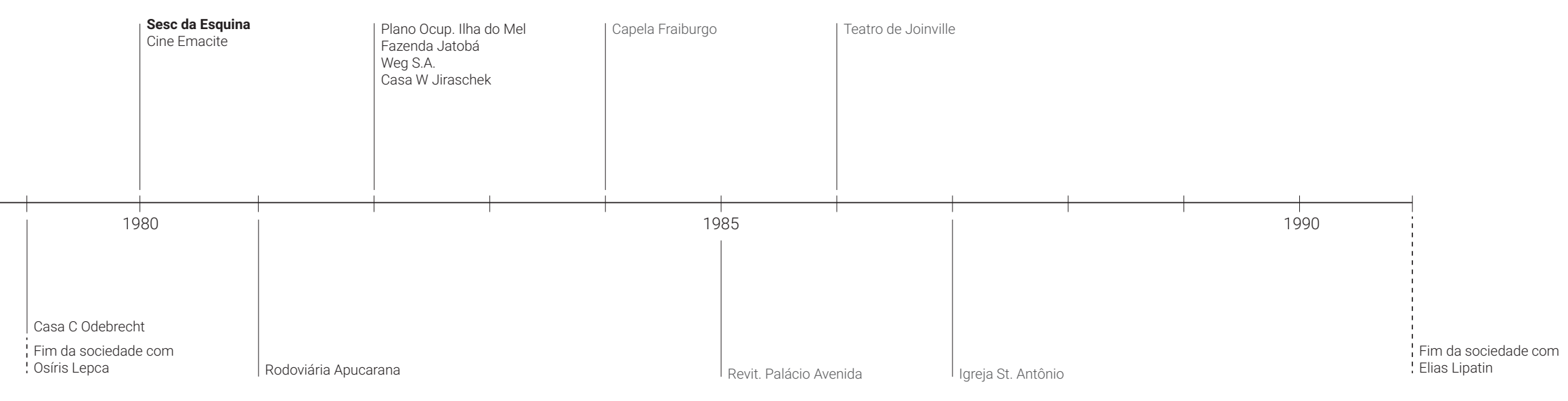




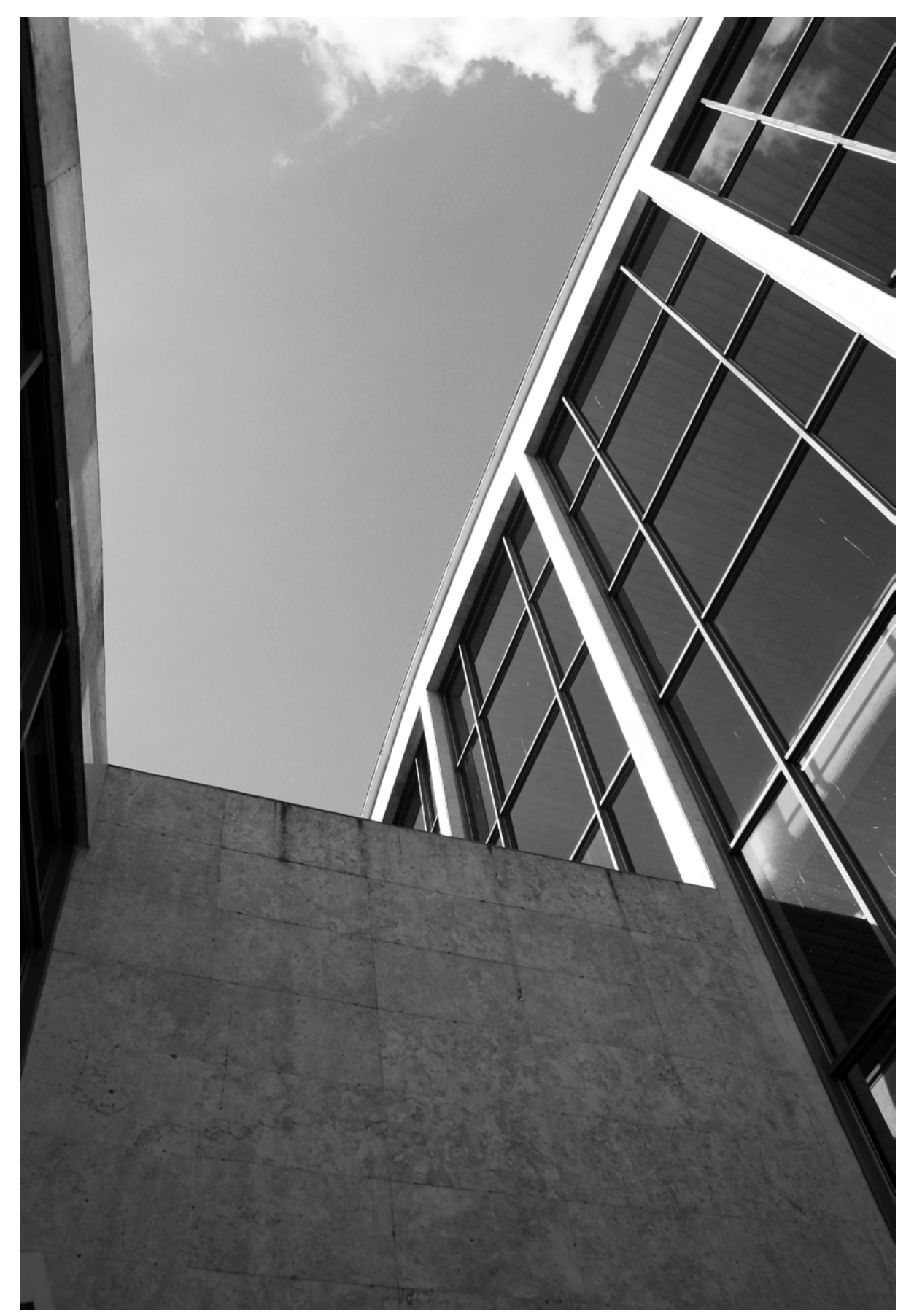




\section{Área}

$20.000,00 \mathrm{~m}^{2}$

\section{Localização}

Rua Conselheiro Laurindo, 175

Curitiba, PR

\section{Cliente}

Governo do Estado do Paraná

\section{Ano de projeto}

1948 (concurso) 1951 (projeto)

\section{Ano de construção}

1952-1974

\section{Gabarito}

5 pavimentos

\section{Colaboradores}

Eugênio Grandinetti, João Lessi, Romeu Paulo da Costa, Osiris Lepca, Erich Nissen, Lauro Meister, Rody Jans, Oswaldo Siqueira, Lothário Seifert, Ario Dergint, José Neto Sperandio, Venevério da Cunha, Joaquim Pontes, Akemi Fukuda e Véspero Mendes

\section{Dados de tombamento estadual}

Inscrição do Tombo 147 - ||

Processo número 06/01

Data da inscrição: 18 de dezembro de 2003 


\section{Introdução}

Formado em engenharia há apenas um ano, Rubens Meister alcançou a sua primeira premiação em um concurso nacional de arquitetura como profissional em 1948. Como estudante, havia recebido o primeiro lugar com o projeto do concurso nacional para o Panteão dos Heróis da Lapa em 1943. Apesar do terceiro lugar no Concurso do Teatro Oficial do Estado do Paraná, o projeto de Meister foi o construído, as razões serão apontadas no decorrer deste capítulo.

Coube então ao jovem engenheiro-arquiteto a responsabilidade de materializar um teatro, espaço que funciona como um cartão de visitas cultural de uma cidade. Em meio a problemas e atrasos com a obra, o Teatro Guaíra esteve sob responsabilidade de Meister por 23 anos, do projeto até a sua inauguração em 1974. Isso equivale a aproximadamente metade da sua longeva vida profissional. O conhecimento adquirido e especialização no assunto (além do gosto pessoal por teatros e óperas) reverberou além do Guaíra: desenvolveu a "Morfogenia dos CineAuditórios", tese realizada no exame para professor titular da Universidade Federal do Paraná em 1957. Esta tese foi apresentada num encontro da Society of Motion Television Engineers no Canadá em 1965, tendo Meister como o representante latino-americano. No âmbito profissional, essa especialização também retornou em forma de projetos: após o Teatro Guaíra desenvolveu o Auditório da Reitoria da UFPR (1955), o Cine Hotel Colón (1956) em Joinville, o Cine Plaza (1958) em Castro, o Cine Emacite (1960) em Mafra, o Cine Marrocos (1962) em Lages, o Auditório do Edifício Lydio Paulo Bettega (FIEP) (1962), o Auditório do SESC da Esquina (1980), o Teatro de Joinville (1986) e o Teatro de Blumenau²1. 


\section{Análise de projeto}

\subsection{IMPLANTAÇÃO E RELAÇÃO COM A CIDADE}

\section{Contexto}

O antigo teatro oficial da cidade de Curitiba, o Theatro São Theodoro, foi inaugurado em 1884 e ocupava um terreno na Rua Dr. Muricy, onde hoje encontra-se a Biblioteca Pública do Estado do Paraná (figura 46). Em 1894 teve as suas apresentações artísticas paralisadas: a Revolução Federalista 22 alcançou Curitiba e utilizou a estrutura do teatro como prisão para os rebeldes que rumavam ao norte. Em 1900 o edifício voltou com suas atividades originais com o nome de Theatro Guayra ${ }^{23}$ (figura 41). Quase quatro décadas depois, Aluízio França, que governou Curitiba por apenas 48 dias, demoliu o teatro em 1937 alegando "precariedade nas instalações" (CARVALHO; BATISTA; CHIESA, 2019, p.81). O prefeito residia em frente ao local e, católico e conservador, via-se incomodado com as atividades do teatro (NISSEN et al., 2016, p.82). Além do mais, "relatos da época trazem ainda amargas lembranças de quando o teatro foi usado como cadeia, durante a Revolução Federalista, e que suas dependências foram palco de execuções." (NISSEN et al., 2016, p.82).

Após a demolição, em 1940, a Academia Paranaense de Letras iniciou uma campanha para a construção de um novo teatro oficial, sob liderança do presidente Ulisses Vieira. Em 1948, o governador Moisés Lupion promoveu um concurso nacional de anteprojeto para o novo Teatro Oficial do Estado do Paraná a ser construído na Praça Rui Barbosa, centro de Curitiba.

22 A Revolução Federalista foi uma guerra civil que aconteceu nos três estados do sul do Brasil entre 1893 e 1895. Foi disputada entre federalistas (maragatos) e republicanos (pica paus) logo anós a proclamação da República, sendo uma das mais sangrentas revoltas travadas no sul do Bras

23 Um dos significados de guá-y-rã é "não passarás adiante! o nome foi colocado por pressão de intelectuais de Curitiba. (NISSEN, 2016, p. 78)

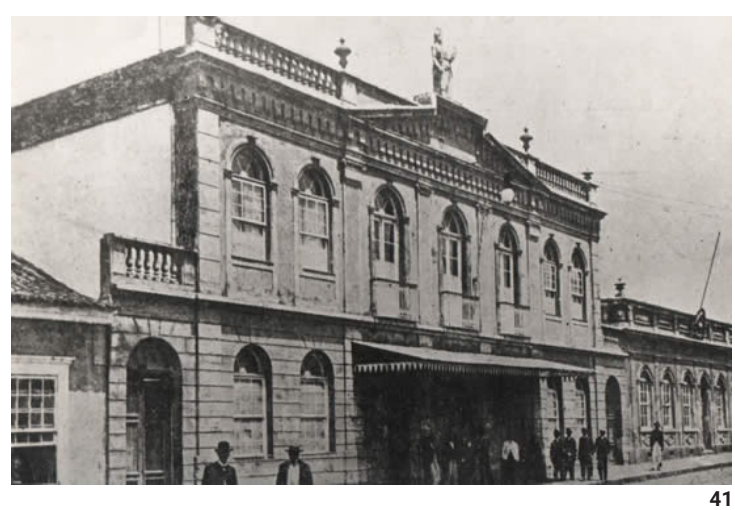

Figura 41. O Theotro Guayra no inicio do século XX. Fonte: site oficial do Teatro Guaira. Disponivel em: http://www.teatroguaira.pr.gov.br/arquivos/Image/auditofios/cctg/02.jpg. Acesso em' 12 out 2019.

$$
41
$$



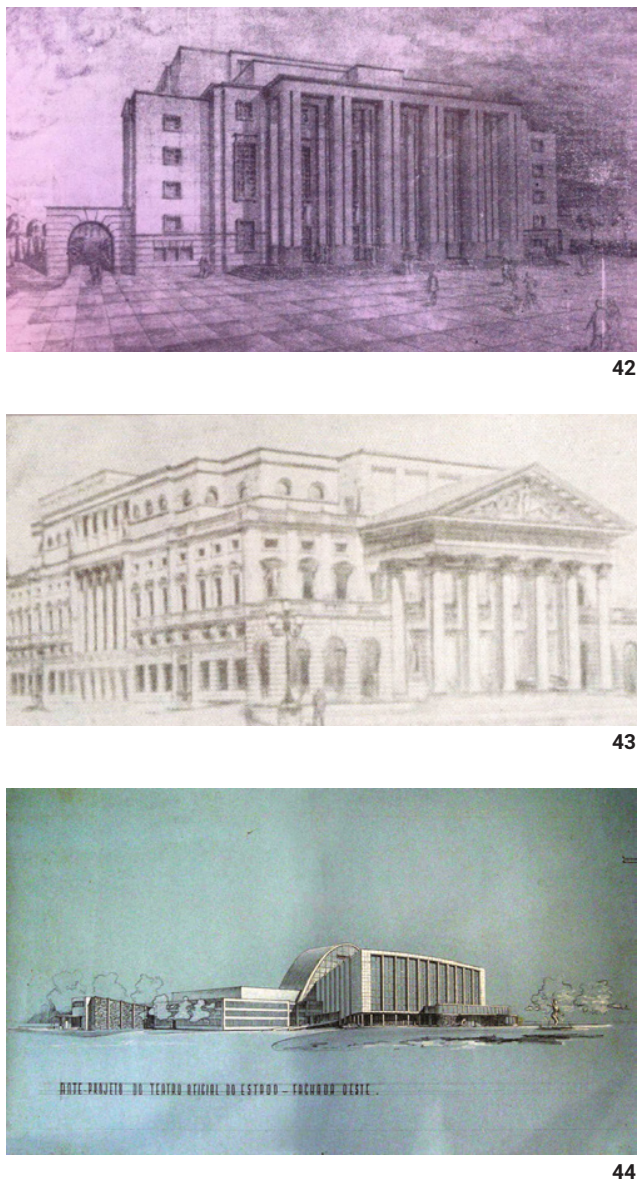

Figura 42 (acima): 0 primeiro colocado no concurso. Disponivel em: <https://www. gazetadopovo.com.br/haus/arquitetura/ teatro-guaira-deveria-ter-outra-cara-projeto-vencedor-considerado-antiquado/>

Acesso em: 12.jan. 2020.

Figura 43 (meio): O segundo colocado no

concurso Fonte: CARVALHO BATISTA.

CHIESA, 2019, p. 93

Figura 44 (abaixo): 0 terceiro colocado no

concurso. Fonte: acervo Rubens Meister,
"Foram entregues dezessete trabalhos, os quais foram apreciados e expostos à visitação pública. A comissão julgadora, de tendência

predominantemente conservadora, demorou-se por mais de um mês discutindo as proposições e escolheu um projeto, de linguagem

neoclássica, como o primeiro colocado, um de linguagem eclética inspirado na Ópera de Paris (de Charles Garnier), para o segundo lugar e, um modernista, para o terceiro colocado"

(NISSEN et al., 2016, p. 84)

O primeiro lugar ficou com a empresa Construtora Nacional do Rio de Janeiro (figura 42), o segundo lugar com a empresa Müller e Caron (figura 43) e o terceiro com Rubens Meister (figuras 44 e 45).

"A oposição estética tomou forma nos jornais" (MEISTER in VIANNA et al., 1999, p. 9) e não demorou para que o diretor da Escola de Música e Belas Artes do Paraná e um dos membros da comissão julgadora do concurso, Fernando Corrêa de Azevedo, se utilizasse de uma página inteira de um jornal em defesa ao projeto "Alceste", nome de identificação escolhido por Rubens Meister e Eugênio Grandinetti.

"Se, no entanto, esses quatro ante-projetos poderiam ser construídos, há, entre eles, um que deverá ser construído. Trata-se do ante-projeto "Alceste", de Rubens Meister e Eugênio Oswaldo Grandinetti, colocado em terceiro lugar. (...) O teatro de Curitiba passaria a ser citado e apontado em todo o mundo, como obra de originalidade ímpar, aliada ao máximo que a técnica moderna pode oferecer em conforto e perfeição no interior. (...) Porque os monumentos devem ser reflexo do seu tempo. Não se pode 
conceber que construamos hoje imitando o que os gregos fizeram na antiguidade helênica, os romanos, os renascentistas, os artistas de outras eras. Triste atestado estaríamos dando a nossa falta de imaginação, espírito e imitação e incapacidade criadora. Não. Nós

temos uma arquitetura típica, que representa o século XX. Uma arquitetura surgida do cimento e de uma mais nítida noção de conforto. Bonita ou feia, é ela fruto de uma época, característico de uma idade, e deverá ficar como representante de um período novo na

arte arquitetônica."

(AZEVEDO, 1949 apud DUDEQUE, 2001, p. 415-418)

Em 1951 Bento Munhoz da Rocha ${ }^{24}$ assumiu o governo do estado. Os ecos do paranismo (movimento regionalista que buscava trazer identidade e novos significados à cultura paranaense após a emancipação do estado) do início do século XX voltaram à tona alimentados pela crescente economia, expansão do território e pelo falecimento de Romário Martins (fundador do movimento) em 1948. O ano de 1953 se aproximava, e com ele o Centenário de Emancipação Política do Paraná. A comemoração dessa importante data não passaria desapercebida por Munhoz da Rocha enquanto as manifestações paranistas saíam do mundo das artes para tomarem um tom mais ufanistas e de maiores proporções, junto às comemorações oficiais do estado.

O governo tinha como meta desenvolver as Obras de Comemoração do Centenário de Emancipação Política do Paraná, utilizando-se da arquitetura e do urbanismo como expressão de um estado moderno e vislumbrando a materialização de Curitiba como capital políticoadministrativa de relevância no cenário nacional. Logo, a argumentação de Fernando Corrêa

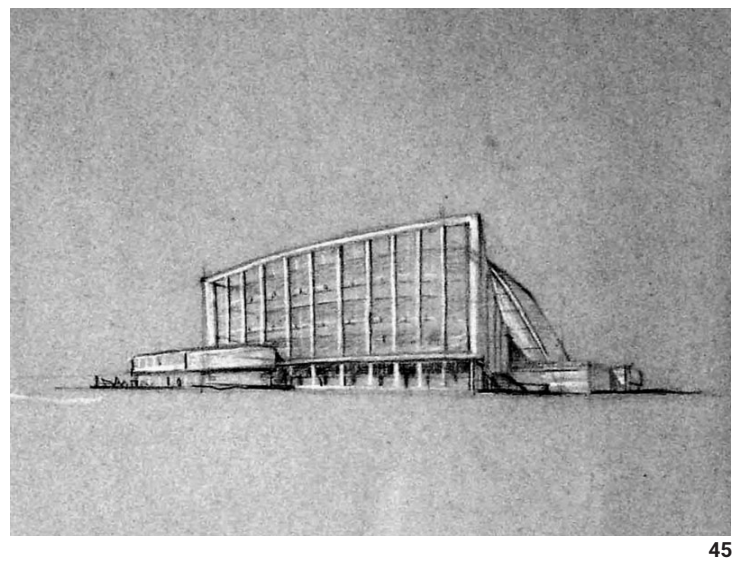



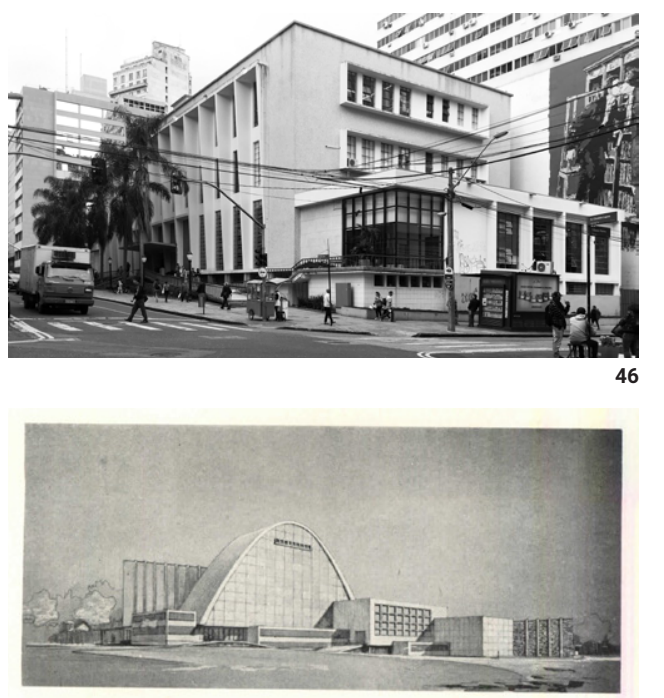

CLRITBa, BRAZIL, PLANS "OFFICLL" THEATER The second prize winner in a competifion sponsored by the government of the Sitote
of Porana in Brozil will be constructed in the ufficial theater, following a hot public debate precipitoted by the chicico of sores troditionol design to receive first prize. The proiect to be buil lophotogrophs of frenderings
obove and belowl was designed by Rubens Meister, professor of orchitecture in the

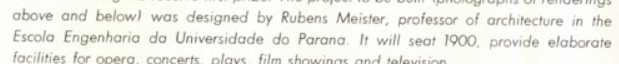

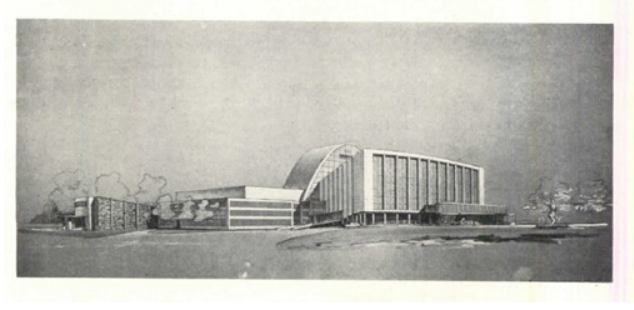

Figura 46 (acima): A Biblioteca Pública do Paraná (1951) de Romeu Paulo da Costa no terreno onde estava situado o antigo

Theatro Guayra. Fonte: Acervo do autor.

Figura 47 (abaixo): Publicação do Teatro Guaira na revista Architectural Record

de 1951. Disponivel em: <https://www

architecturalrecord.com/articles/13598-ar-

chitectural-record-archives>. Acesso em:

29.jan.2019. de Azevedo sustentada pelo zeitgeist ${ }^{25}$ e a postura adotada em favor de uma nova arquitetura teve fundamental influência sobre o novo governador que optou por não acatar o resultado do concurso, demonstrando interesse em construir o projeto de Meister e Grandinetti.

"Ele me chamou, queria ver o meu projeto, conversou e depois ficou meu grande amigo. (...) o Munhoz da Rocha não influiu em nada. Só pediu que eu aumentasse o número de lugares de 1900 para 2300. Queria fazer o maior possível para reduzir o custo da entrada. Então

eu estudei essa alteração até onde foi possível, porque o teatro

poderia ser ainda maior."

(MEISTER in VIANNA et al., 1999, p.10)

Como previsto por Corrêa de Azevedo, a escolha pelo projeto de Meister culminou em uma ampla divulgação por parte da imprensa, revistas e jornais. Atingiu o seu ápice ao ser o primeiro registro da arquitetura paranaense nos periódicos internacionais, sustentando parte de uma página da revista norte-americana Architectural Record (dezembro de 1951, p.14) (figura 47).

Originalmente projetado para a Praça Rui Barbosa, o terreno do teatro foi alterado para a Rua Conselheiro Laurindo, em frente da Praça Santos Andrade, a pedido de Munhoz da Rocha (figuras 50 e 51). Menor e mais regular, o espaço previsto ainda mantinha uma quadra inteira e era originalmente ocupado por um clube de tiro, o Tiro Rio Branco (NISSEN et al., 2016, p.44) (figura 48 e 49).

"O teatro deveria ser construído na Praça Rui Barbosa. Bento Munhoz da Rocha não quis usar a praça, porque era coisa sagrada. Gottfried Herder e remonta às características culturais e intelectuais de um determinado período 
Ao invés de ser feito lá, foi escolhido o local onde está agora, que era o local do antigo Tiro Rio Branco. Um terreno menor, mas possível de ser feito o Teatro, e em frente à Universidade do Paraná, e assim

ficariam o clássico e o moderno se confrontando. A ideia era boa." (MEISTER,1995 in BERRIEL; SUZUKI, 2012, p.58)

O projeto executivo teve início no escritório que funcionava no próprio canteiro da obra (NISSEN et al., 2016, p. 88) e as questões técnicas envolvendo um teatro eram um desafio para um jovem engenheiro que atuava como arquiteto em uma cidade pequena e em crescimento. O aprendizado com este trabalho foi relevante na sua formação, desde a experiência em obra e gestão até o domínio construtivo.

"Havia alguns teatros modernos na Suécia. Na Alemanha, o primeiro teatro moderno começou a ser construído só em 1955, em Colônia. Para os europeus, um teatro não deveria ser tão grande, para eles um teatro de mil lugares já é imenso. Então nós não tínhamos

elementos para estudar. (...)A parte técnica de cenografia é muito complicada. Recorri a vários livros mas não pude visitar teatros que já existiam. Mas éramos uma província. Achava-se que viagem era sinônimo de distração ou vadiagem. Acabei não saindo do Brasil para

conhecer outros teatros."

(MEISTER in VIANNA et al., 1999, p.8 e 10)

Os problemas de acústica e visibilidade foram estudados a partir de livros estrangeiros e tiveram auxílios remotos do arquiteto alemão Ben Schlanger (GNOATO; SUTIL, 2005, p. 65), Rino Levi que havia projetado o Teatro Cultura Artística (1942) e o do engenheiro italiano e cenógrafo
Figura 48 (acima): Tiro Rio Branco no terreno do Teatro Guaíra e entorno em 1935 Disponivel em: <http://www.curitibaantiga com/fotos-antigas/232/Praça-SantosAndrade-em-1930.html >. Acesso em: 06.out.2019.

Figura 49 (abaixo): Praça Santos Andrade e aos fundos o Tiro Rio Branco no terreno cada de 1930. Fonte: Fundação Cultural de Curitiba (FCC) Casa da Memória.
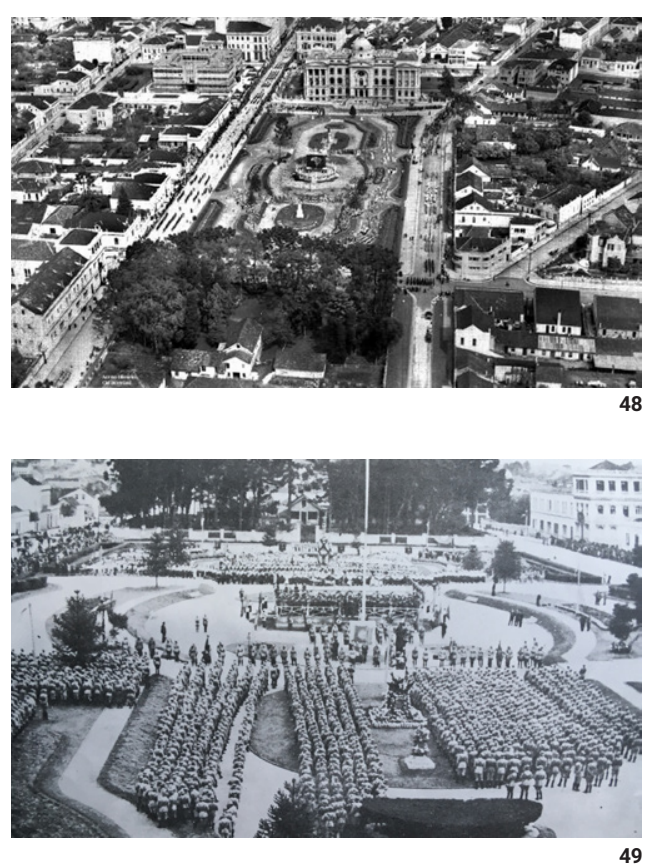
Figura 50 (à esquerda): Situação do centro e arredores de Curitiba em 1952 . Fonte Instituto de Pesquisa e Planejamento Urbano de Curitiba (IPPUC) e editado pelo autor

Figura 51 (à direita): Situação do centro e arredores de Curitiba 2018 Fonte: Google Earth e editado pelo autor

(

... Eixo da Rua XV de Novembro

1 Tiro Rio Branco / Teatro Guaira (1951) 2 Passeio Público

3 Praça Tradentes | Generoso Marques 4 Theatro Guayra I Biblioteca Publica (1952) 5 Praça Rui Barbosa

6. Centro civico do Estado do Parana (1951)
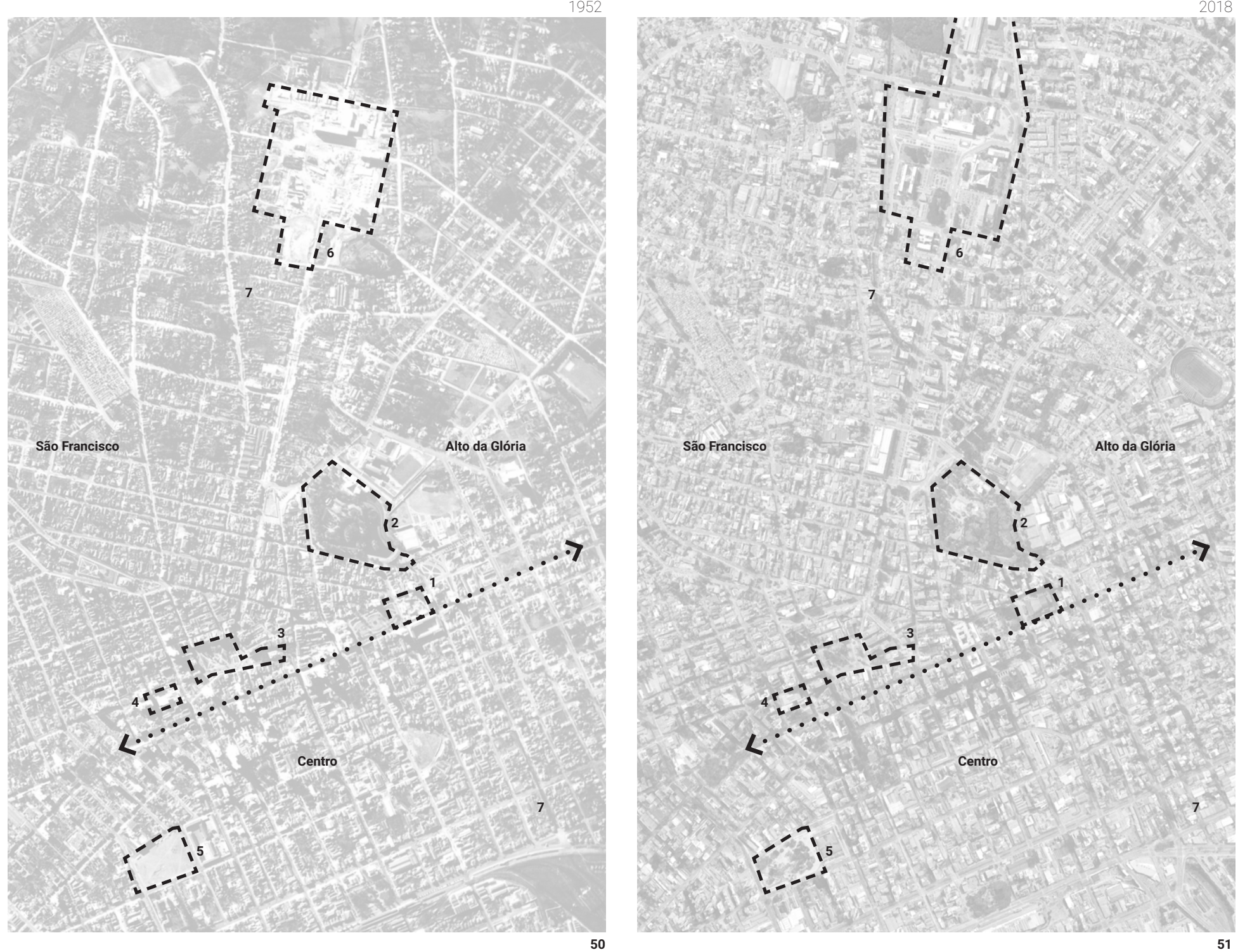
do Teatro Alla Scala de Milão, Pericle Ansaldo (MEISTER in VIANNA et al., 1999, p.13).

As obras começaram em 1952, sendo que dos três auditórios (grande auditório, médio e miniauditório) o de porte médio, Salvador Ferrante (popular "Guairinha”), ficou pronto em 1954 com 504 lugares. A paralisação das obras dos demais setores do Teatro Oficial do Estado foi deveras regional: as safras de café (um dos principais componentes da economia paranaense junto à erva-mate) foram atingidas por severas geadas nos anos de 1954 e 1955 (DUDEQUE, 2001, p. 175). A obra foi paralisada em seguida e retomada somente em 1966. Outros projetos públicos, como o Centro Cívico (1951), também sofreram com a crise no estado.

"De civilizador, Munhoz da Rocha transmigrou-se num faraó sonhador amaldiçoado pela praga da geada: (...) Por muitos anos, as ossadas estruturais dos edifícios do Centro Cívico jazeram inúteis, emolduradas pelo capinzal. O mesmo aconteceu com o Teatro Guaíra. O auditório menor, conhecido como Guairinha, foi inaugurado logo após o centenário. O auditório maior acolheu, em bancos improvisados, o público que assistia à Orquestra Sinfônica Brasileira, na festa do centenário do Paraná. Depois dos acordes finais, as obras foram interrompidas, iniciando uma rotina de paradas e reinícios que culminaria com um incêndio em 1970." (DUDEQUE, 2001, p.177)

Em 1970, próximo da conclusão, houve um incêndio de grandes proporções e o grande auditório, Bento Munhoz da Rocha Netto, foi inaugurado apenas em dezembro de 1974 com 2.173 lugares. O terceiro e último auditório, o Glauco Flores de Sá Brito, foi inaugurado em 28 de agosto de 1975 com 113 lugares, completando os 16.900 metros quadrados de área construída e os 2.790 lugares totais do complexo
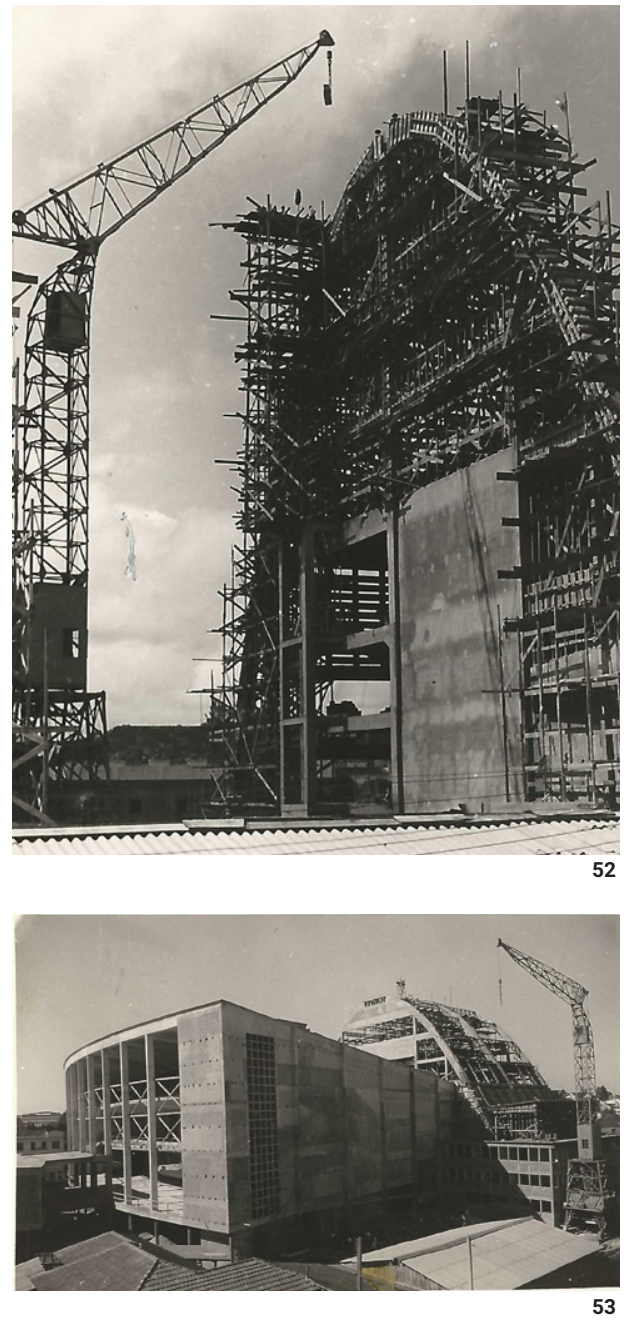

Figura 52 (acima): A concretagem de um arco nas obras do Teatro Guaira. Fonte: Acervo Rubens Meister

Figura 53 (abaixo): Obras do Teatro Guaíra em meados da década de 1950. Fonte: Acervo Rubens Meister 
Figura 54 (acima): Panorâmica mostrando Q Teatro Guaíra à direita e a Universidade Federal do Paraná à esquerda (1959) Fonte: Fundação Cultural de Curitiba

Figura 55 (abaixo): Imagem aérea mostrando a relação do teatro com a universidade (2018). Fonte: Google Earth Acesso em: 22.nov.2019.
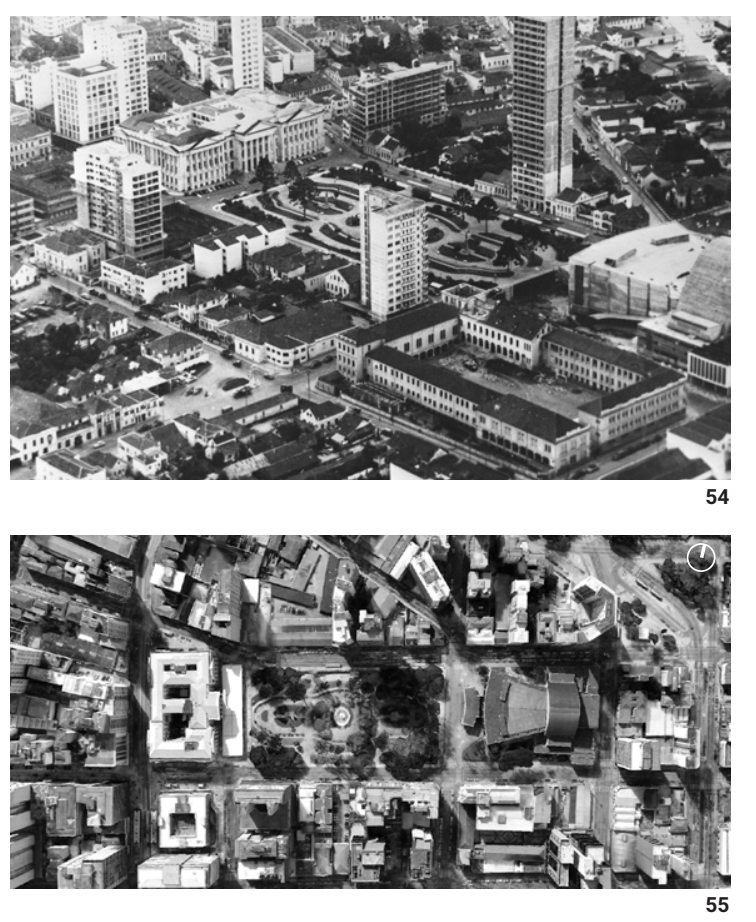

Decorrente deste período, a arquitetura moderna passou a ser assumida como linguagem oficial nas obras do estado e alguns projetos acabaram se tornarando novos marcos referenciais urbanos. Dentre eles, as obras feitas para as comemorações do centenário: o Centro Cívico do Estado do Paraná (David Xavier Azambuja, Sérgio Rodrigues, Olavo Reidig de Campos e Flávio Régis do Nascimento, 1951), o Grupo Escolar Tiradentes (Rubens Meister, 1951), os painéis e esculturas da Praça 19 de Dezembro (Erbon Stenzel e Poty Lazzarotto, 1951), o Teatro Guaíra (Rubens Meister, 1951), a Biblioteca Pública do Paraná (Romeu Paulo da Costa, 1951) (figura 46) e o Hipódromo do Tarumã (Edmir D’ávila, 1952).

Essas obras marcaram a afirmação deste novo movimento na capital até então dominada pela arquitetura eclética. Para a realização das mesmas, foi criada a Comissão Especial de Obras do Centenário (CEOC) que tinha como objetivo a execução dos projetos durante a gestão.

Com o aval do poder público à arquitetura moderna nas ações de comemoração do centenário de emancipação política do Paraná, Curitiba começou a configurar, a partir da década de 1950, um sítio propício para jovens arquitetos desenvolverem e materializarem propostas inovadoras e originais. Inicialmente pouco aceito, o desenho moderno ao longo do tempo foi crescendo e tendo reconhecimento pela opinião pública, derivando, em grande parte, de uma ideia de futuro e progresso da sociedade.

\section{Relação com a paisagem urbana}

Conforme comentado por Rubens Meister, a mudança do local de projeto permitiu que um projeto moderno pudesse enfrentar um projeto clássico, no caso, o teatro viria a contrapor o prédio histórico da Universidade Federal do Paraná (figuras 54 e 55). Em meio a isso, o principal palco cívico da cidade de Curitiba, a Praça Santos Andrade. Até o início das obras, a praça possuía uma vegetação de baixo porte, preenchida por gramados e arbustos. O vazio aéreo - em decorrência da ausência de árvores maiores - permitia uma maior compreensão desta relação entre o novo e o antigo, entre uma linguagem arquitetônica que era dominante nos 


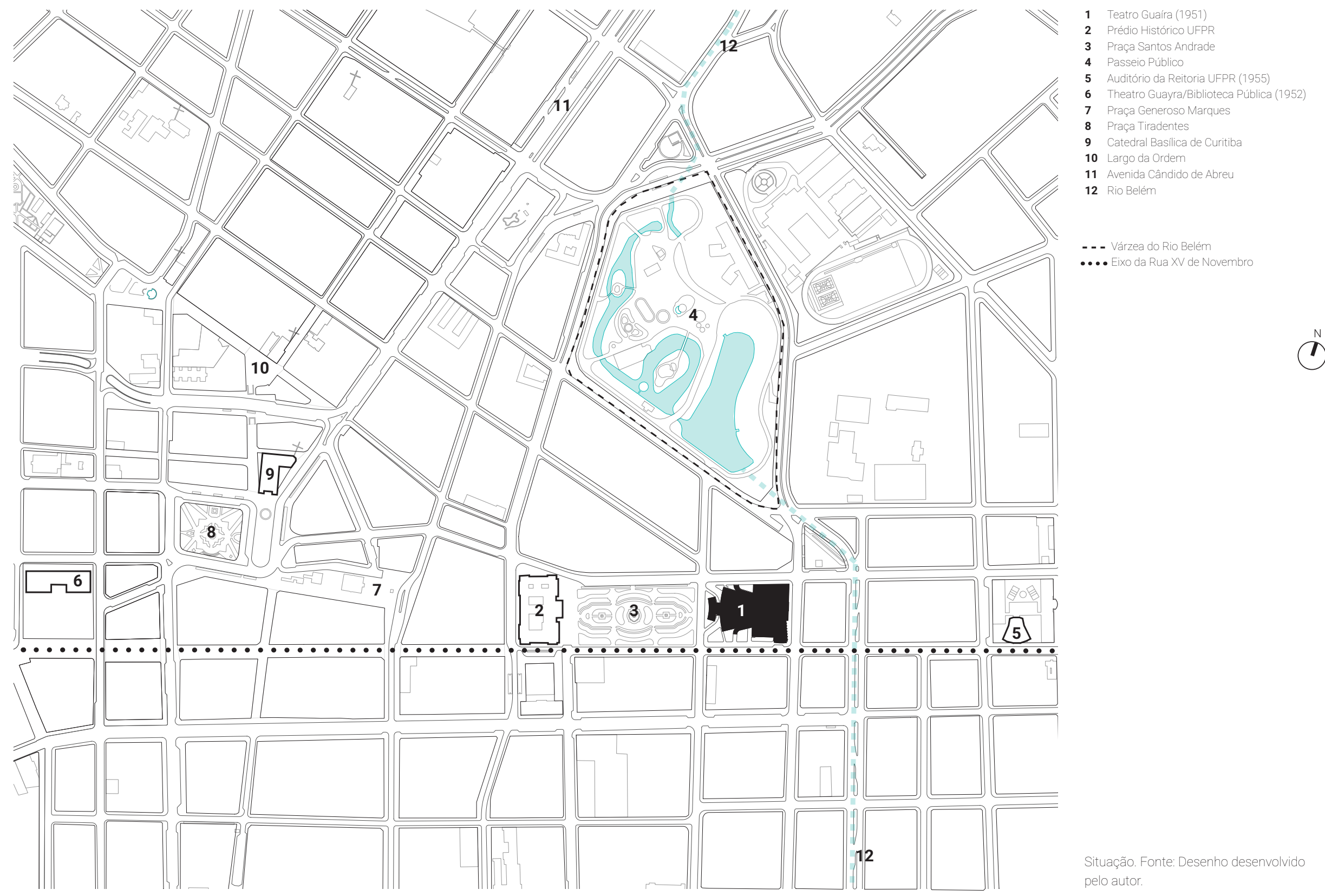



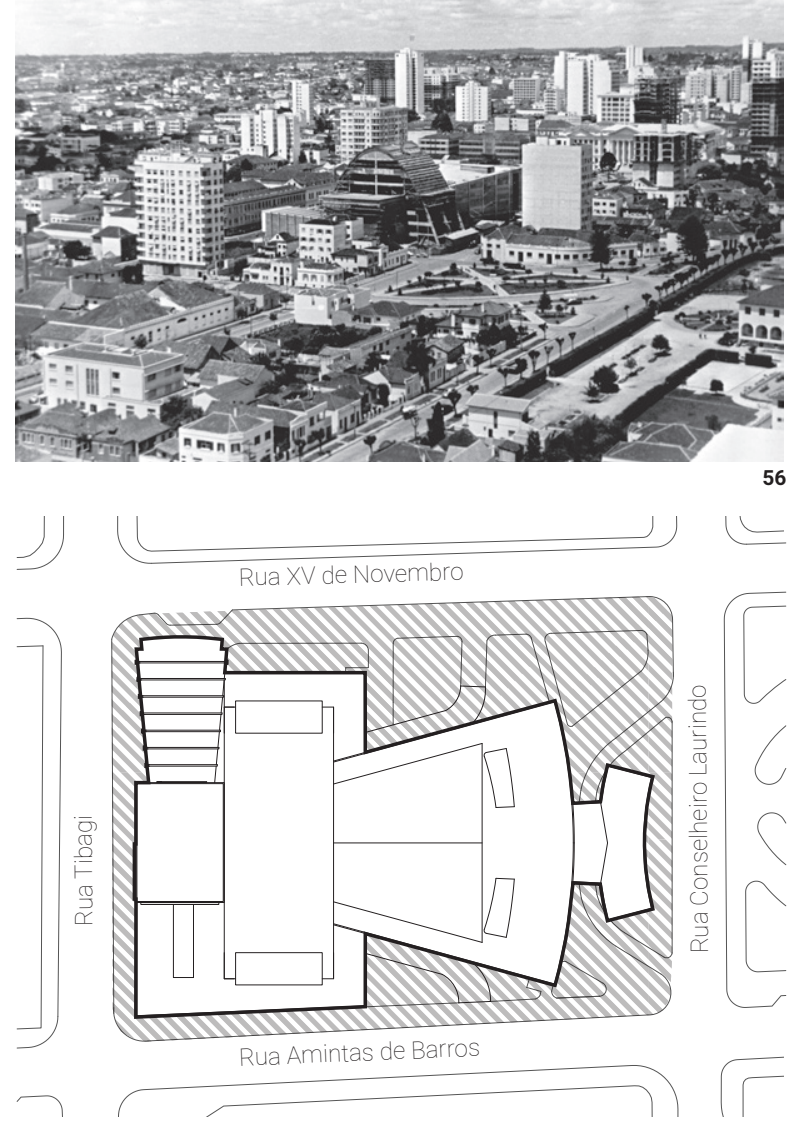

$(1$

Figura 56 (acima): A inserção do Teatro Guaíra no contexto central de Curitiba em meados da década de 1950. Fonte: Fundação Cultural de Curitiba.

Abaixo: Relação do teatro com o terreno Fonte: Desenho desenvolvido pelo autor À direita: Esquema de implantaçoes do teatro na Praça Rui Barbosa (1948) e em frente à Praça Santos Andrade (1951). Fonte: Desenho desenvolvido pelo autor.

prédios públicos de Curitiba e uma que viria a ser a partir de então.

A rua $X V$ de Novembro, importante artéria histórica e cultural da cidade, limita o terreno à sul-sudeste. A leste-nordeste está a Rua Tibagi e no cruzamento entre ela e a Rua Amintas de Barros a norte, encontra-se o Largo Bittencourt, sendo este limítrofe ao Passeio Público, espaço de lazer e o mais antigo parque de Curitiba e idealizado para sanear uma várzea do Rio Belém. No limite a oeste-sudoeste, a Rua Conselheiro Laurindo separa a fachada principal do teatro da Praça Santos Andrade, que por sua vez limita-se, no lado oposto, com o prédio histórico da Universidade Federal do Paraná. O Teatro Guaíra, dessa forma, destacou-se no contexto urbano ao se posicionar entre três importantes espaços públicos da cidade (planta de situação na página anterior e figura 56).

\section{Relação com o terreno}

Adaptado do projeto para o concurso na espaçosa Praça Rui Barbosa e transferido para a nova quadra, o teatro ocupa quase todas as extremidades do terreno. De sobreposições de blocos que aproveitavam o espaço e condicionadas ao formato trapezoidal da praça, a implantação passou a ter um desenho diferente, com destaque para os blocos de apoio ao uso do teatro e para o auditório médio. Este último ficou menos destacado e solto do complexo e foi orientado à Rua XV de Novembro. Esta aglutinação fica mais evidente ao se comparar as implantações das duas propostas (esquema de implantação abaixo).

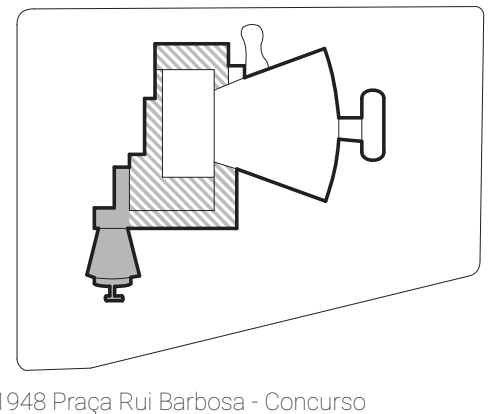

1948 Praça Rui Barbosa - Concurso

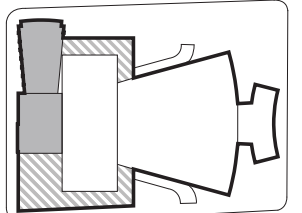

951 Praça Santos Andrade - Projeto 


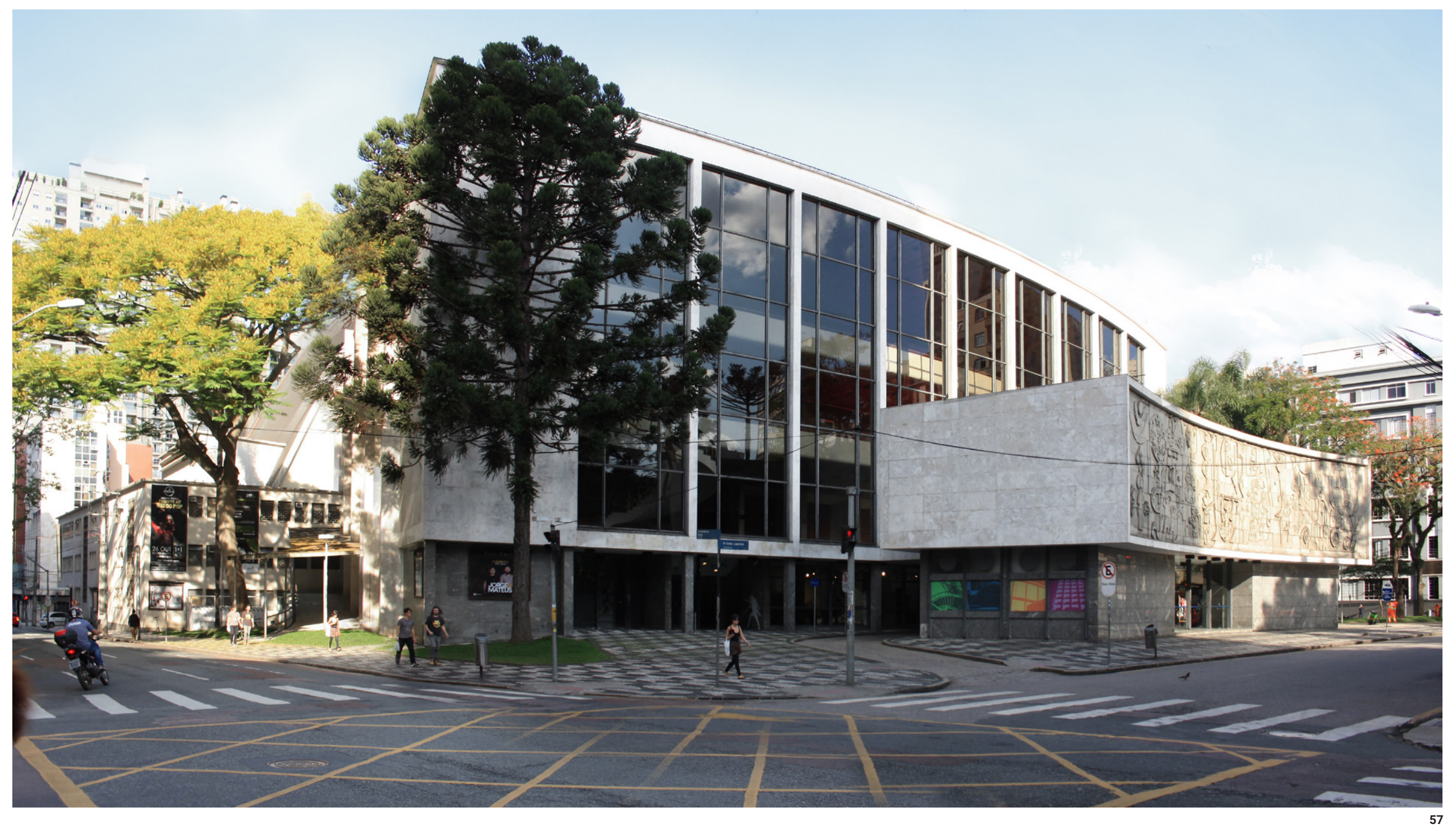




\section{$\infty_{N}$}

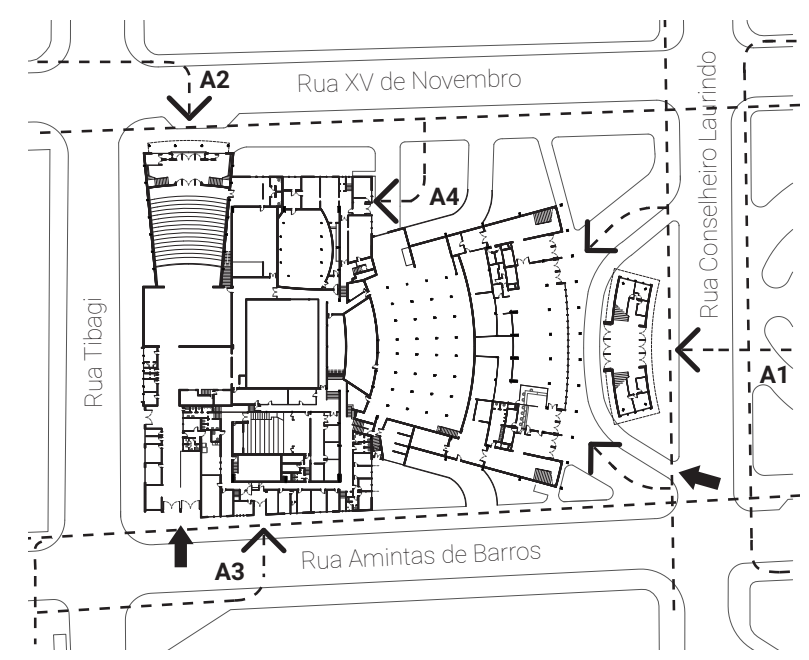

- - - Percursos

4- - Acesso pedestre

— Acesso veículo

Figura 57 (página anterior): Teatro Guaíra Fonte: Acervo do autor.

Nesta página: Percursos e acessos. Fonte: Desenho desenvolvido pelo autor.
O "núcleo duro" do projeto, correspondente ao grande auditório (foyer, plateia e palco), sofreu alterações em menores proporções e, sendo também o acesso principal de pedestres e desembarque de veículos, foi orientado à praça em frente.

O paisagismo, composto essencialmente por desenhos de pisos e canteiros, ocupa os espaços laterais do terreno da frente até aproximadamente o meio da quadra. Em frente à fachada principal havia inicialmente uma proposta que contemplava espelhos d'água que não chegaram a ser construídos.

\section{Percursos externos e acessos}

Pode-se chegar ao Teatro Guaíra a partir de quatro esquinas e pela Praça Santos Andrade. $\mathrm{Na}$ esquina norte, para quem chega pelo Largo Bittencourt, observa-se um pequeno e discreto acesso que leva ao miniauditório, o Flores de Sá Brito.

A partir da esquina leste, no cruzamento das ruas XV de Novembro e Tibagi, o bloco correspondente ao auditório médio (Auditório Salvador Ferrante) ganha protagonismo na cota mais baixa do terreno. A distinção do setor ao restante do complexo é imediata e o acesso ao saguão e foyer é claro e convidativo.

A fachada principal mostra-se como um grande marco a partir das esquinas sul (entre as ruas XV de Novembro e Conselheiro Laurindo) e oeste (entre as ruas Conselheiro Laurindo e Amintas de Barros) e, principalmente, quando observada do meio da Praça Santos Andrade. O eixo da praça e do prédio da Universidade Federal do Paraná ganha o reforço da simetria da fachada principal do teatro. 0 acesso é central, voltado à frente (pedestres) e à parte de trás (embarque e desembarque de veículos), e distribuído lateralmente pelas escadas a partir de um bloco do saguão, solto ao volume do foyer elevado. No térreo, sob esse volume maior, estão as bilheterias, localizadas atrás do acesso principal. 0 painel em frente, de Poty Lazzarotto ${ }^{26}$,

26 Napoleon Potyguara Lazzarotto (1924-1998), ou Poty Lazarrotto, foi um muralista, gravurista, desenhista e ceramista paranaense. Formou-se em 1945 na Escola Nacional de Belas Artes do Rio de Janeiro e autor de importantes murais como o da Casa Brasil (Paris, 1950) e de paineis como o do Memorial da América Latina (São Paulo, 1988) e do Centro Politécnico da UFPR (1956), entre outros. 

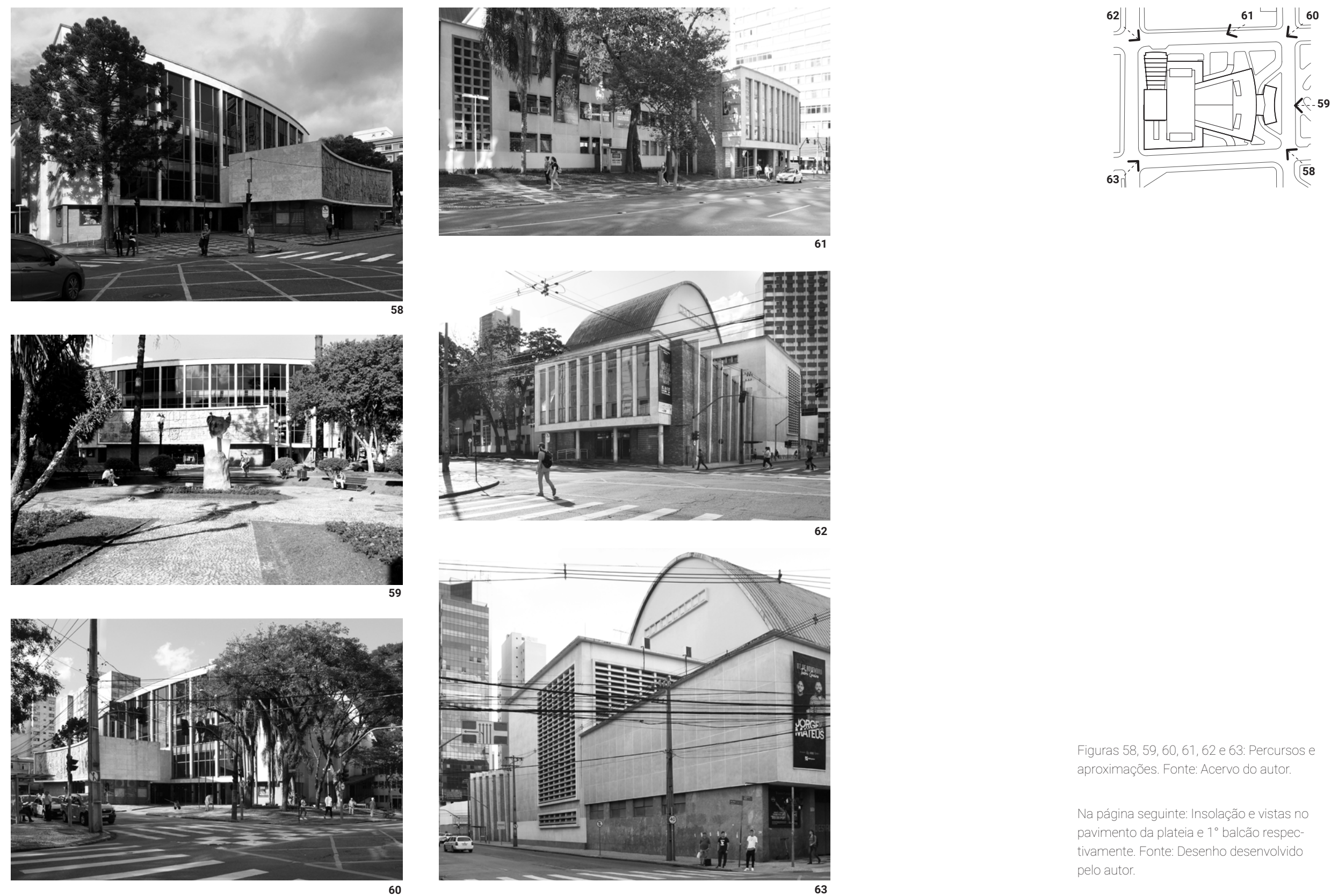

Fiquras 58, 59, 60, 61, 62 e 63: Percursos e aproximaç̃os. Fonte: Acervo do autor.

Na página seguinte: Insolação e vistas no pavimento da plateia e $1^{\circ}$ balcão respectivamente Fonte: Desenho desenvolvido pelo autor 


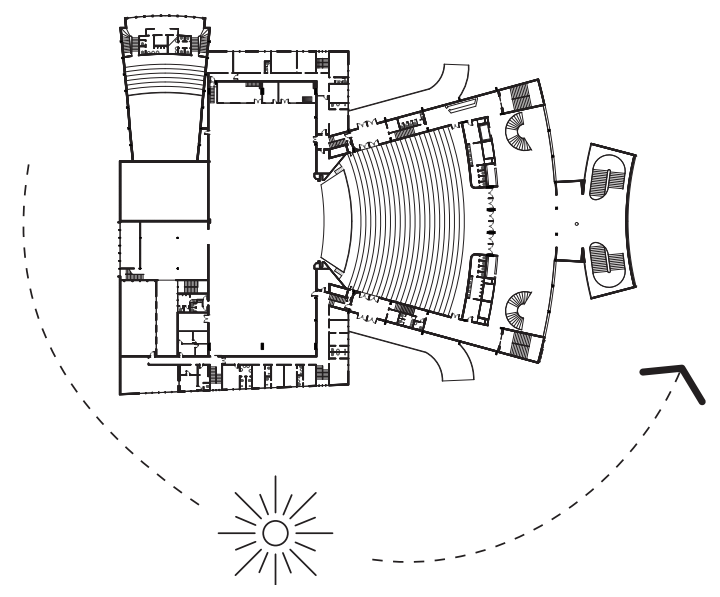

funciona como um monumento que leva arte à praça.

As sobreposições dos blocos tentam comunicar visualmente os diferentes usos do complexo, entretanto, a compreensão do todo não é simples tendo em vista as distintas fachadas. 0 adensamento do entorno não permite um afastamento que pudesse facilitar a legibilidade. A praça seria o espaço que proporcionaria um território observável da fachada principal, e assim foi. No entanto, a vegetação ao longo dos anos tomou boa parte do espaço visual da praça.

\section{Orientação, insolação e vistas}

O projeto partiu de uma premissa muito clara: voltar o teatro para a Praça Santos Andrade.

$\kappa$

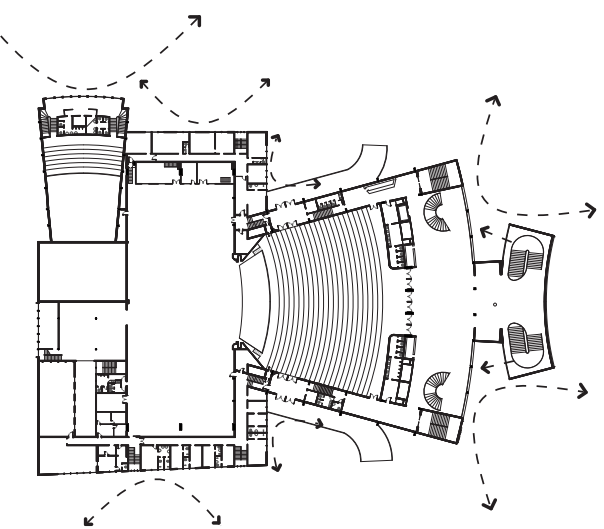

(1)

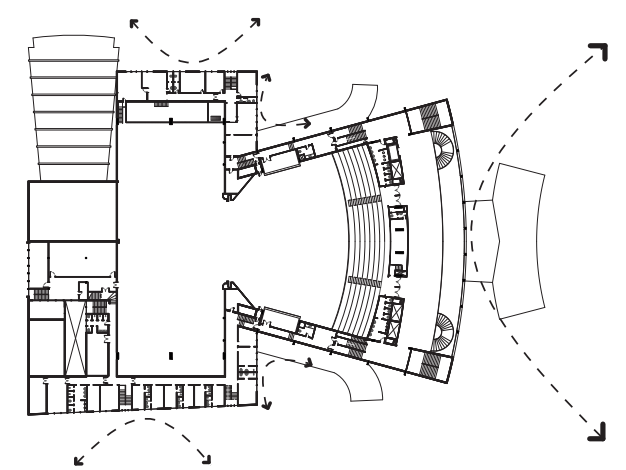

Se as questões de conforto e insolação não foram critérios na implantação da edificação e das aberturas envidraçadas, as vistas para a cidade e praça o foram. Nota-se, entretanto, que mesmo quando o projeto ainda estava situado à Praça Rui Barbosa o desenho da elevação frontal pouco se alterou. A orientação dessa fachada principal era a mesma, oeste-sudoeste. A vista que se tinha era de uma pequena porção de espaço público com tratamento paisagístico no próprio terreno, fruto da proposta de Meister, somada de perspectivas para a Rua 24 de Maio. Pode-se afirmar então que Meister tinha como objetivo maior integrar visualmente o foyer com a cidade em sacrifício do controle térmico de uma fachada banhada pelo sol da tarde. Com a mudança, estas vistas internas a partir dos balcões voltaram-se às copas das árvores da Praça Santos Andrade e à fachada principal do edifício da Universidade Federal do Paraná.

Situação semelhante e em menor escala possui o acesso ao auditório médio. Voltada a sulsudeste, a fachada de aberturas generosas relaciona o andar superior à Rua XV de Novembro.

As demais vistas ocorrem através de esquadrias modestas e sem proteções, localizadas nos dois blocos mais baixos, um de cada lado do arco. Estão elas voltadas à diferentes orientações, para as ruas XV de Novembro e Amintas de Barros, e possuem os mesmos tratamentos e dimensões. É valido destacar que aqui novamente a incidência solar não foi adotada como critério de projeto. 


\subsection{FORMA, ESPAÇO E PROGRAMA}

\section{Setorização e programa}

O relacionamento entre o uso e geração de forma permitiu dividir o Teatro Guaíra em três setores que delineiam a sua geometria: Grande Auditório (Auditório Bento Munhóz da Rocha Netto), Auditório Médio (Auditório Salvador Ferrante ou "Guairinha") e setor administrativo/ apoio. Apesar de ser acessado através deste último setor, o Miniauditório (Glauco Flores de Sá Brito) está incorporado ao Grande Auditório por sua estrutura situar-se abaixo da caixa cênica. A nomenclatura por pavimentos seguirá a classificação adotada por Rubens Meister nas plantas originais: subsolo, térreo, plateia, $1^{\circ}$ balcão e $2^{\circ}$ balcão.

O maior e principal setor, que corresponde ao grande auditório, pode ser fragmentado em cinco subsetores: saguão, exposições, foyer, plateia e caixa cênica. À exceção da área expositiva, todos os demais subsetores estão direcionados a atender a programação do palco principal.

No subsolo e em partes do térreo abaixo da plateia, o programa ramifica-se em salas de apoio ao teatro. Esse setor abrange também toda a área em volta do arco do palco principal, com destaque para os camarins nos pavimentos plateia e $1^{\circ}$ balcão. No subsolo e térreo, além do auditório menor, há uma concentração maior de salas de ensaio bem como apoio técnico aos palcos e salas administrativas. Nos pavimentos superiores estes usos localizam-se em pontos específicos.

O auditório médio divide-se em saguão, foyer, plateia e caixa cênica. Internamente, as caixas cênicas dos dois auditórios estão centralizadas, sendo que ambas se conectam aos apoios de palco e salas de ensaio. O palco do Auditório Salvador Ferrante possui, no entanto, seus camarins voltados aos fundos da edificação

O corte longitudinal confirma uma organização vertical de usos e não segmentada por pavimentos. O setor administrativo/apoio ocupa todos os níveis dos blocos em volta do palco principal, do subsolo e de uma porção do térreo abaixo do grande auditório.
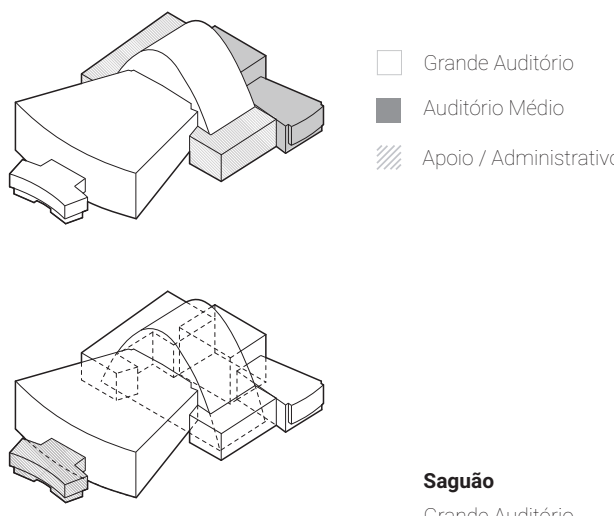

Saguão Grande Auditório

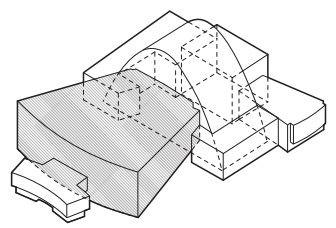

\section{Foyer / Plateia}

Grande Auditório

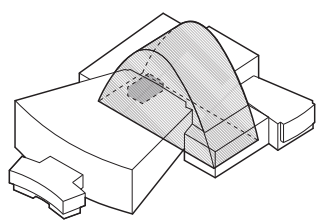

Caixa cênica

Grande Auditório

Miniauditório (abaixo)

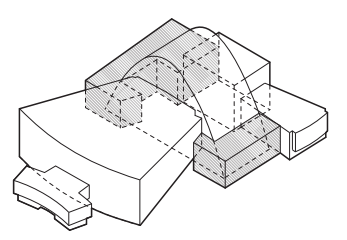

Apoio técnico / Camarim Ensaios / Administração

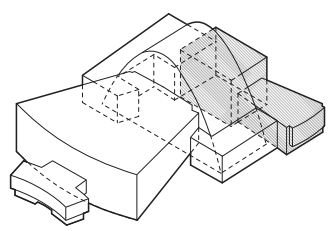

Plateia / Caixa cênica Auditório médio (Guairinha) 


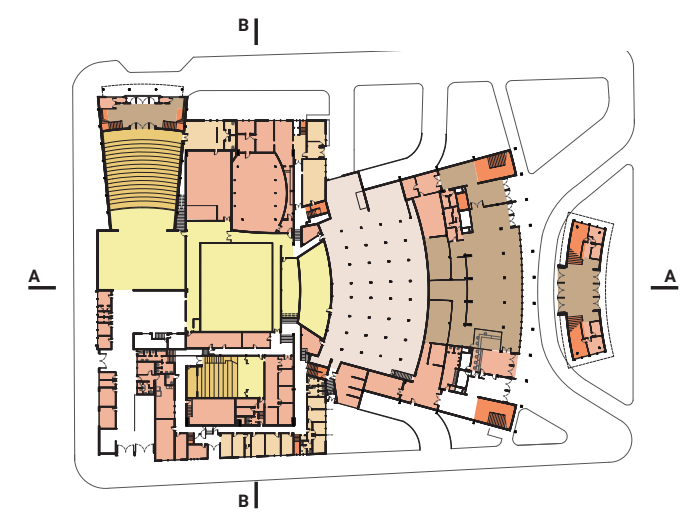

Térreo

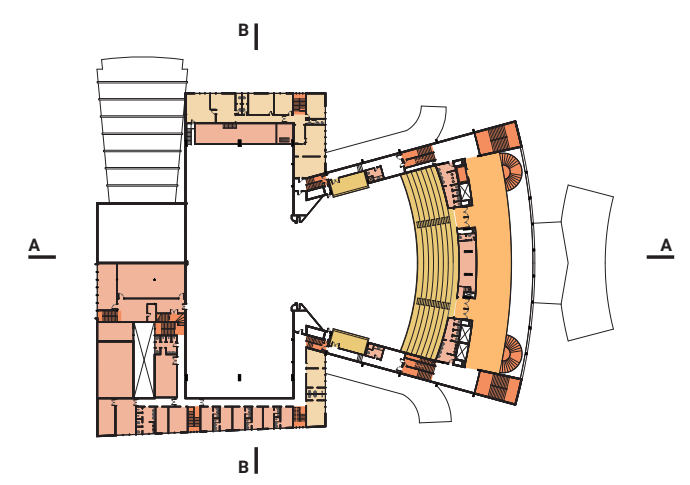

$7^{\circ}$ balcão

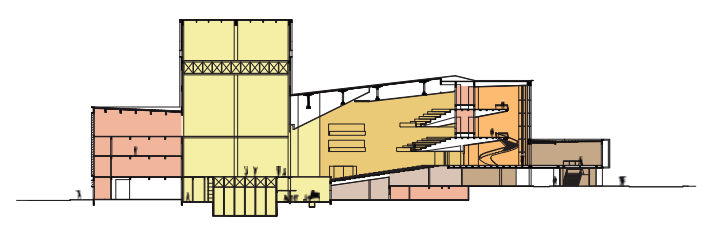

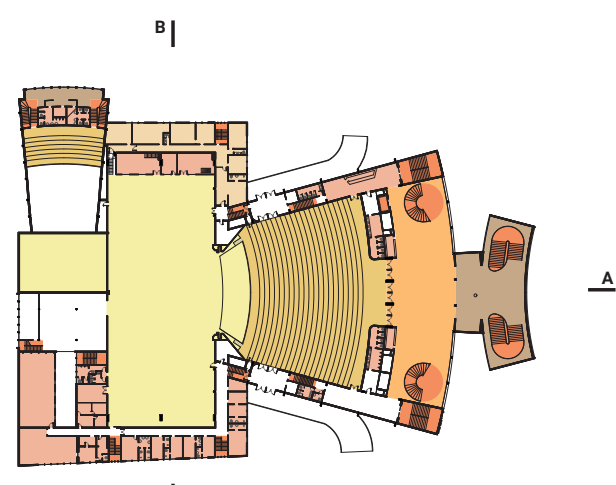

в।

Plateia

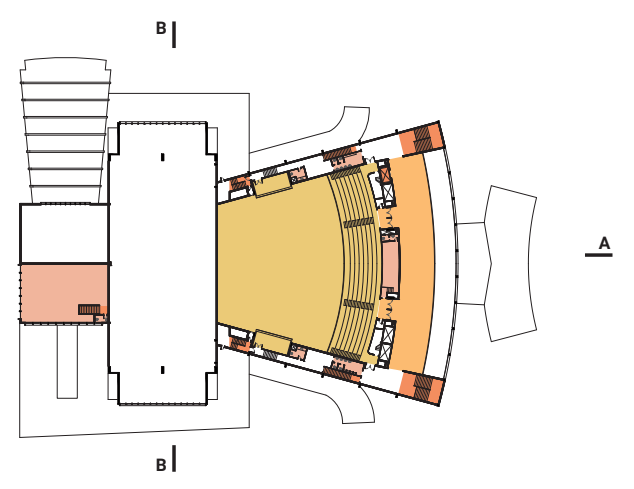

$2^{\circ}$ balcão

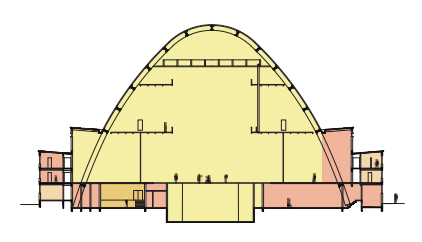

Corte BB - Transversal
Administrativo

- Plateia

Apoio (Camarins, Ensaios, Técnico)

- Circulação vertical

Foyer

Palco / Caixa cênica

- Saguão/Exposiçōes

Estacionamento

Zona pública

W//, Zona privada

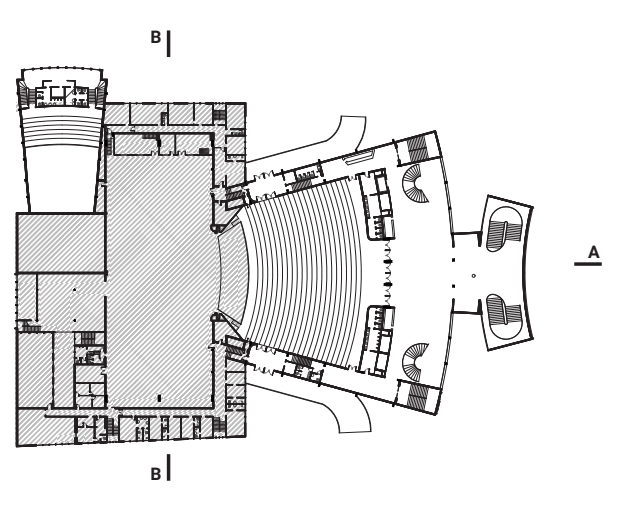

Planta

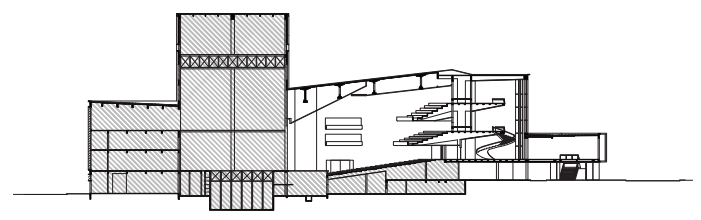

Corte 

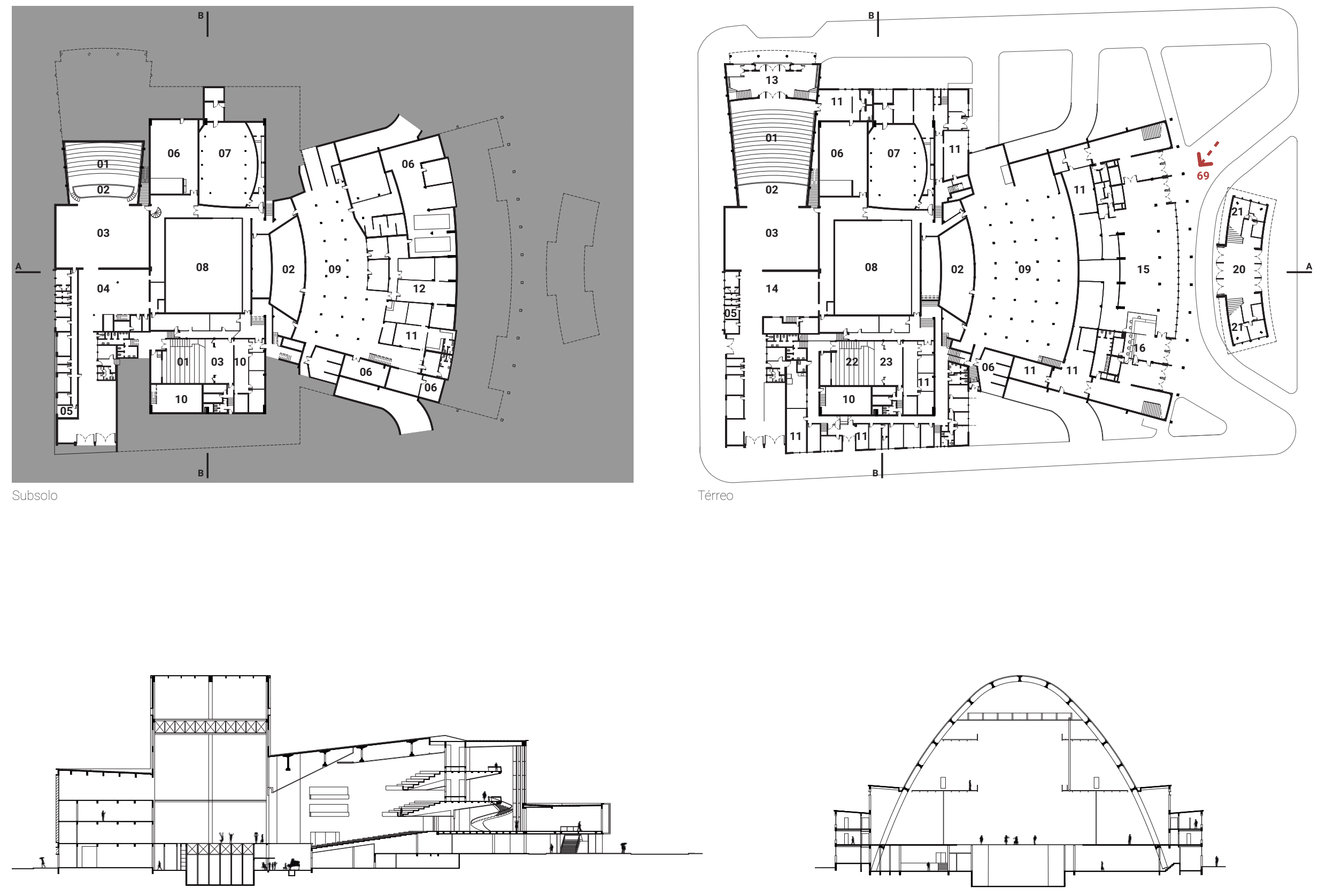
${ }^{8}$
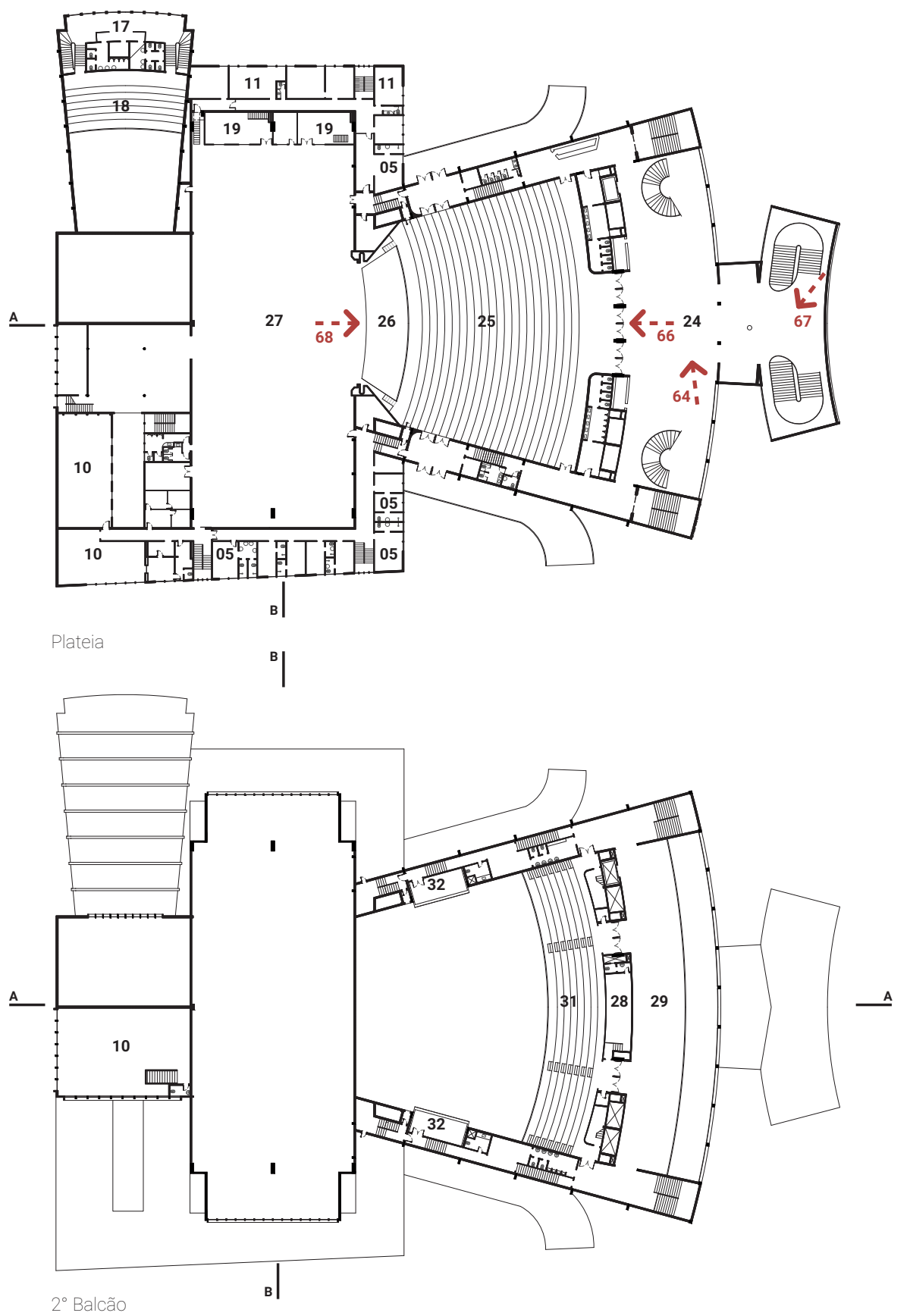

${ }^{8}$

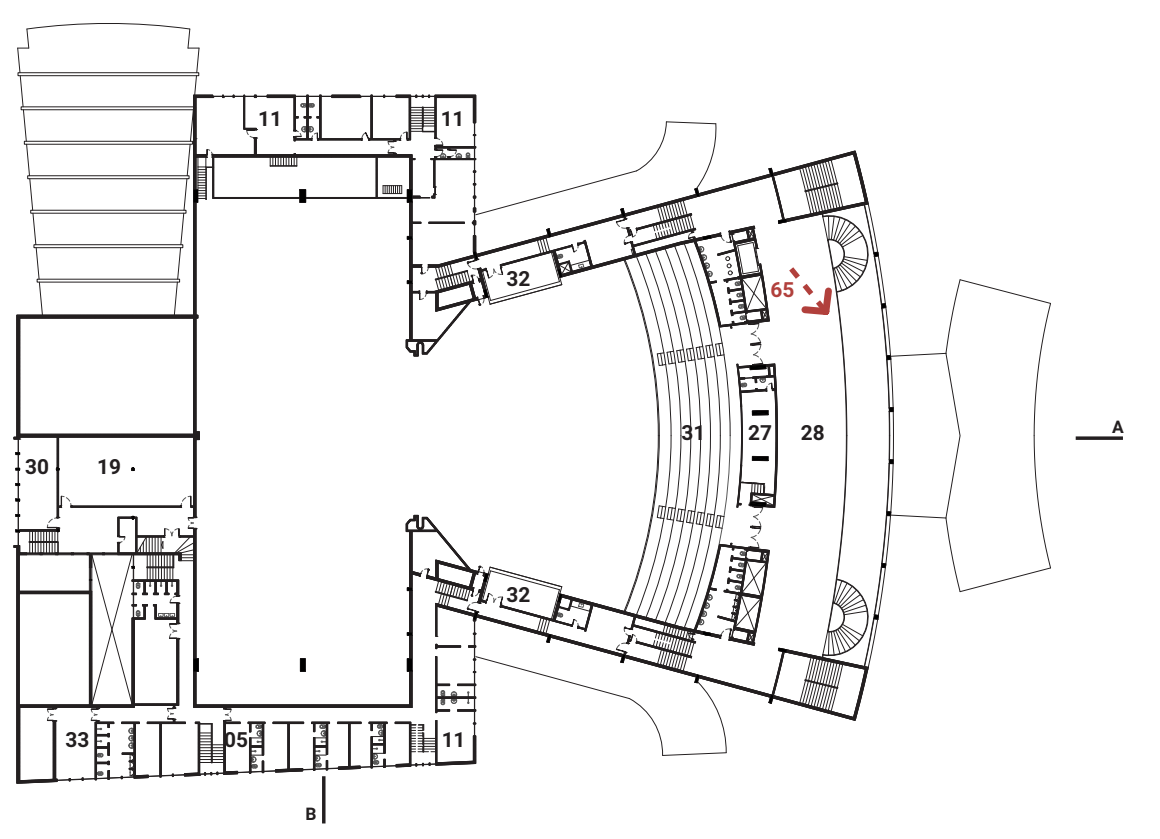

$1^{\circ}$ Balcão

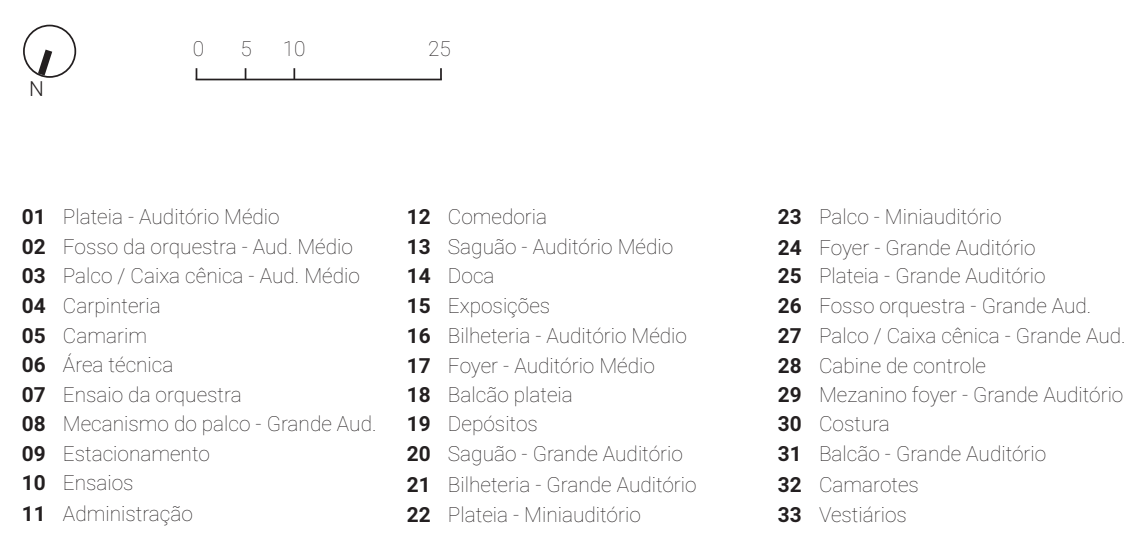




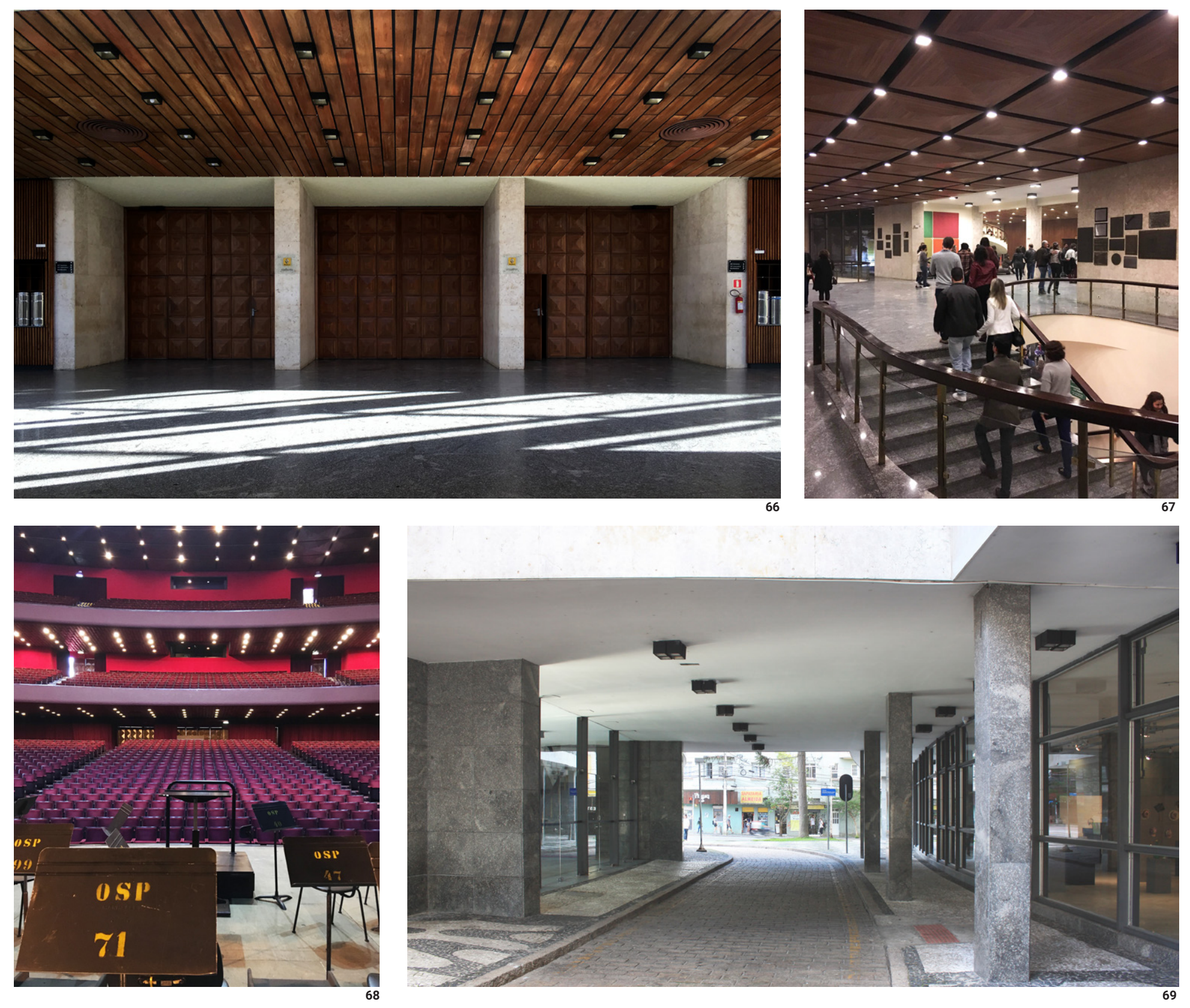


\section{Circulações e percursos internos}

O percurso de maior evidência, a partir do grande auditório, busca cumprir seu objetivo principal: a distribuição do público em três pavimentos e sua evacuação pelas laterais. Do acesso principal, sobe-se um pavimento através de duas escadas periféricas que desembocam no saguão, conduzindo o usuário ao foyer novamente pelo centro da edificação. Funciona este nível como um piano nobile, no qual a entrada para a plateia também é centralizada com o foyer e saguão. 0 acesso ao pavimento acima ( $1^{\circ}$ balcão) é feito através de escadas helicoidais, uma em cada extremidade do foyer. Para o $2^{\circ}$ balcão o acesso se dá através das escadas localizadas nas duas empenas cegas do maior volume. Um elevador, dos quatro previstos em projeto, acessa todos os pavimentos desde o térreo

O auditório médio segue uma lógica semelhante, porém mais enxuta. O acesso central leva diretamente ao foyer e plateia enquanto duas escadas laterais conduzem ao balcão superior. Os fundos do palco deste auditório e o mecanismo da plataforma, que conduz ao palco do grande auditório, estão interligados - nos pavimentos subsolo e térreo - com as docas (carga/descarga), carpintaria/montagem, depósitos, camarins e ensaios da orquestra.

Chega-se ao miniauditório através da circulação oriunda do acesso pela Rua Amintas de Barros (A3). No lado oposto desta circulação (nas laterais do arco) os percursos visam conectar (após os lances de escada) os camarins até o palco através de dois pavimentos (plateia e $1^{\circ}$ balcão) e as áreas técnicas e de apoio aos fundos do palco do grande auditório. O acesso pela Rua XV de Novembro (A4) conduz às salas administrativas nos pavimentos térreo, plateia e $1^{\circ}$ balcão e a um camarim ao lado do palco no pavimento plateia.

\section{Relações entre espaços internos e externos}

No grande auditório (Auditório Bento Munhóz da Rocha Netto) a relação visual entre os balcões do foyer e o espaço externo é a mais evidente e explícita do conjunto. Ela encontra-se em espaço nobre e está presente em toda a fachada principal, ausente de filtros ou quebra-sóis.
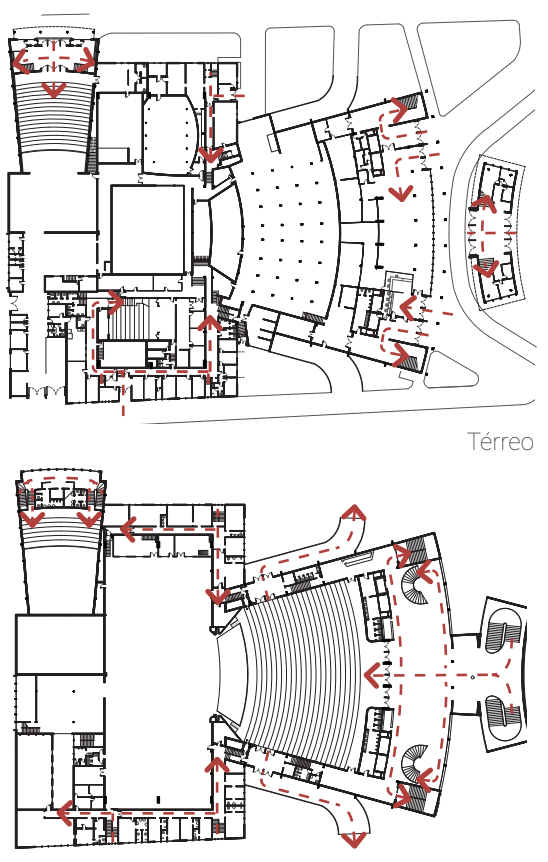

Plateia

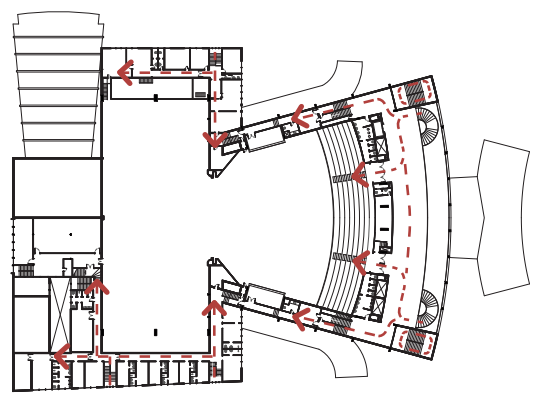

$1^{\circ}$ Balcão

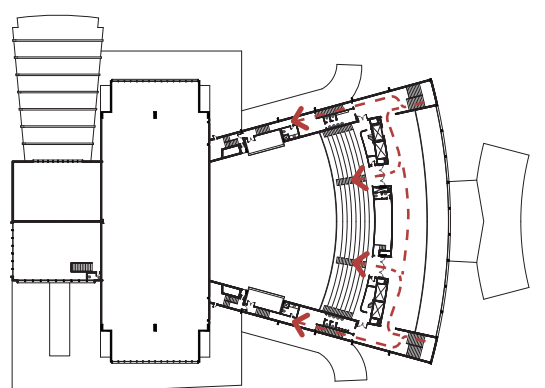


Acima: Relações visuais no foyer. Fonte Desenho desenvolvido pelo autor.

Figuras 70 e 71 (abaixo): Relações visuais entre o interno e externo. Fonte: Acervo do autor
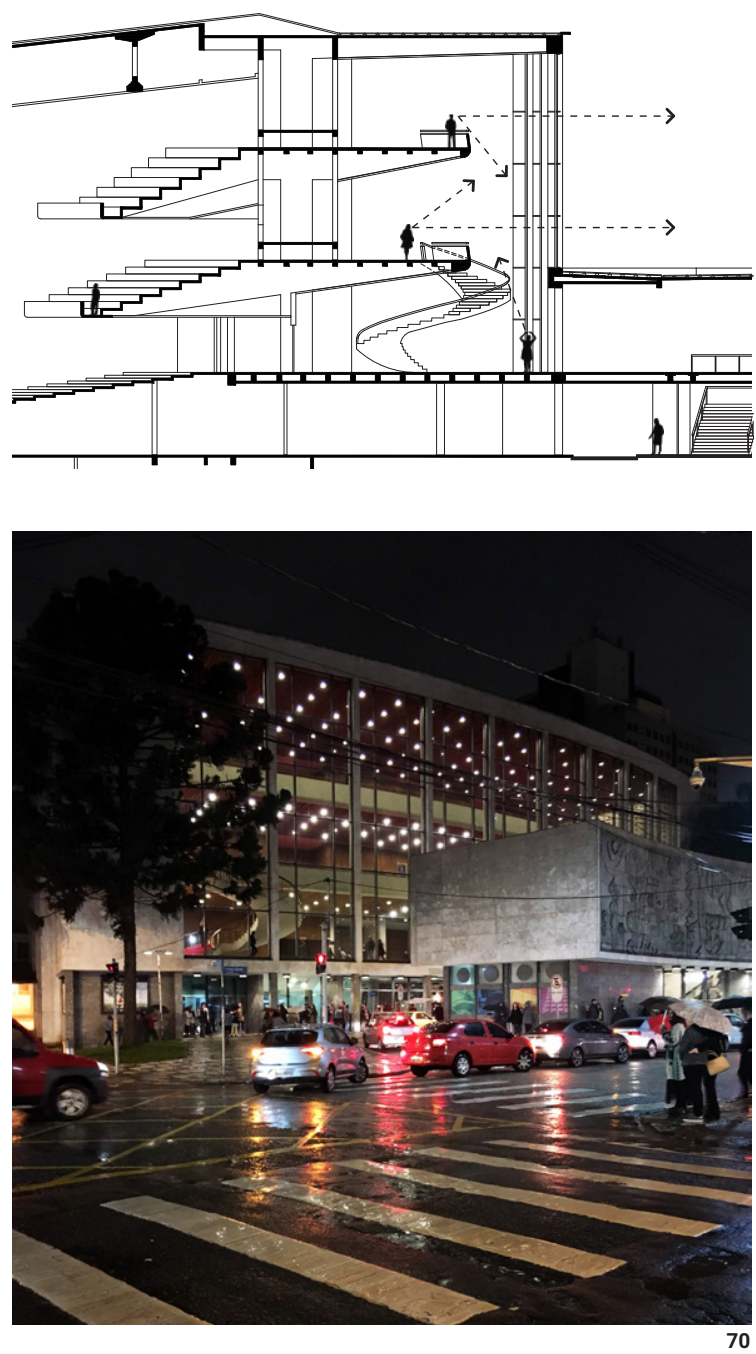

Sem necessidade de descobrimentos ou aberturas pontuais, ela se abre para a Praça Santos Andrade em sua totalidade. Apesar do teatro estar levemente deslocado do eixo de simetria da praça e do prédio da Universidade Federal do Paraná (por uma questão de implantação que envolve o auditório médio), podem ser observados diferentes enquadramentos, através do $1^{\circ} \mathrm{e}$ $2^{\circ}$ balcão

Como relatado anteriormente, o diálogo visual do edifício com a cidade foi uma solução adotada desde o início do projeto (figura 70 e 71), quando havia previsão de implantação em outra localidade. Tendo em vista esta igualdade de propostas para sítios distintos, é válido afirmar que uma das intenções de Meister, com essa fachada, era também de estabelecer uma conexão visual com o interior a partir do exterior. Se para um observador de fora da edificação a percepção do funcionamento do foyer em períodos diurnos não é tão clara, nos noturnos é muito evidente (figura 70). O teatro muda de feição, e o seu funcionamento torna-se um espetáculo à parte para a cidade

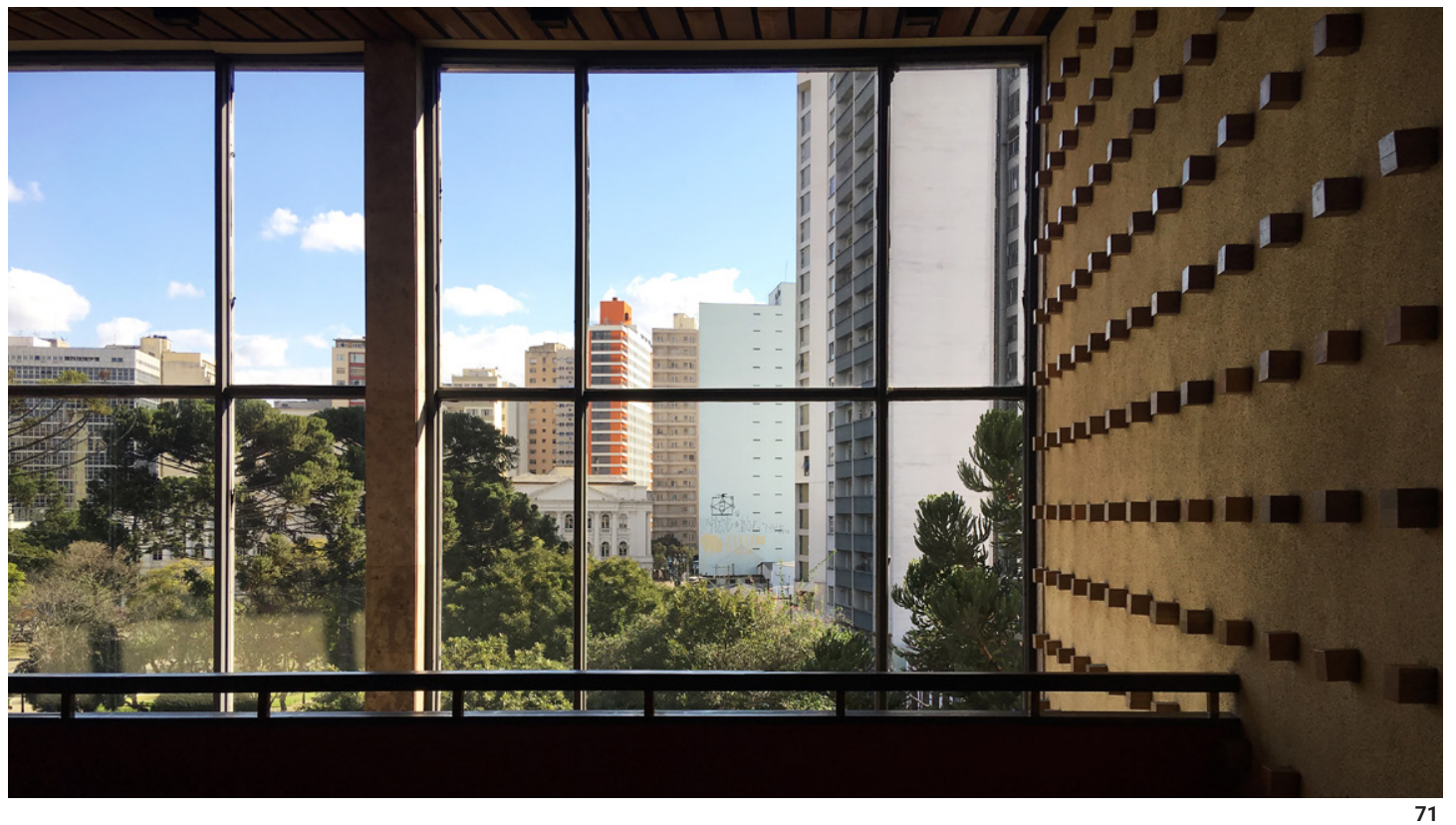





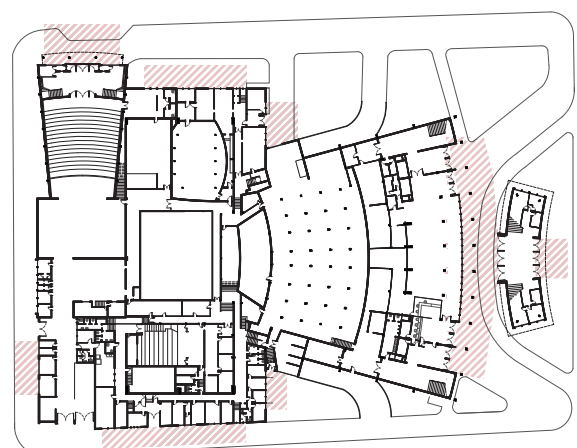

Térreo

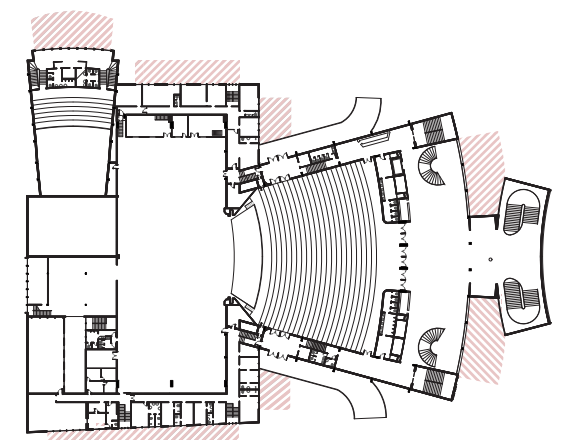

Plateia

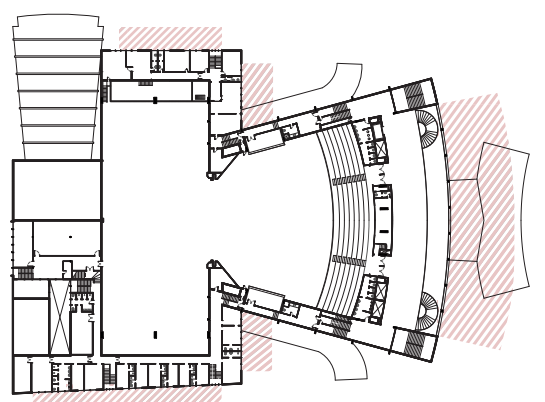

O auditório médio (Auditório Salvador Ferrante) também possui aberturas voltadas à rua em seu pavimento superior. Os planos transparentes são mais verticais e limitados em tamanho, mas que ainda conseguem transmitir a vida interna ao exterior. As circulações verticais nos blocos periféricos limitam-se à cidade a partir de cobogós presentes nas fachadas. As demais transparências ocorrem repetidamente através das janelas que iluminam as áreas administrativas e de camarins.

\section{Iluminação natural}

Com relação ao acesso ao foyer, Meister optou por generosos planos translúcidos que banham estes ambientes (figura 72). No médio e grande auditório, a incidência da luz neste ambiente é total. Estabelece-se relações nos planos horizontais e verticais que podem ser bem observadas em planta e corte.

No restante dos espaços o edifício é, em geral, concebido de forma independente à competência solar. Os camarins e áreas administrativas recebem boa incidência de luz a partir da fachada externa, ao contrário dos ambientes de apoio dispostos ao centro do complexo, sacrificados ante à densidade do programa.

Nas elevações, a luz cria nuances nas curvas da fachada principal e no mural acima do acesso central (figura 73). Nas demais fachadas, as sobreposições dos blocos funcionam como elementos que jogam entre sombra e luz (figura 74). A edificação, trabalhada como volumes e formas, possui algumas reverberações modulares externas na fachada principal e nas empenas laterais de ambos os teatros. Tais soluções exprimem os arranjos estruturais de parte do projeto e configuram, com auxílio da luz e da sombra, matizes às elevações. 

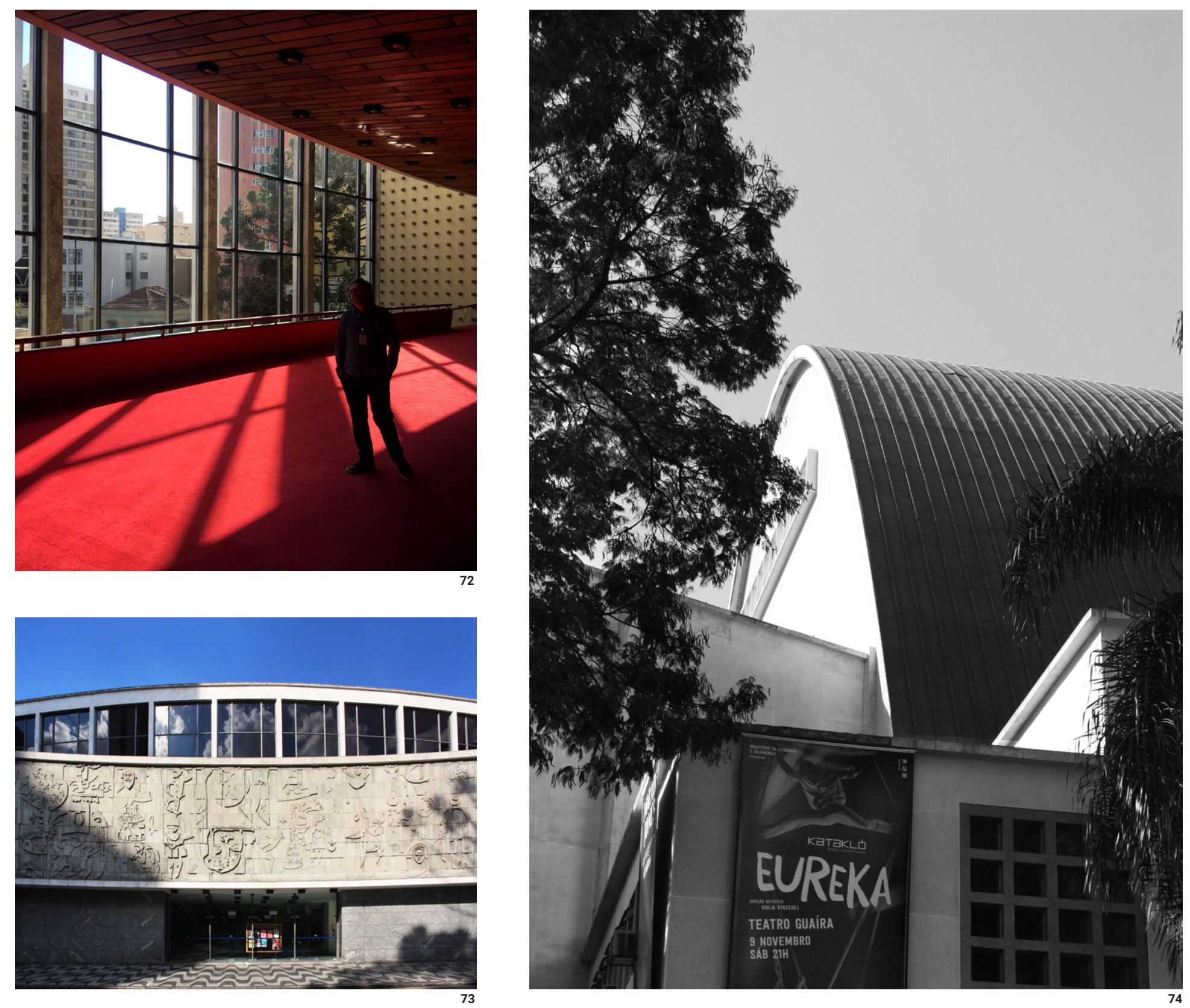

Figura 72 (à esquerda acima): A fuminação natural no foyer do grand auditorio. Fonte: Acervo do autor

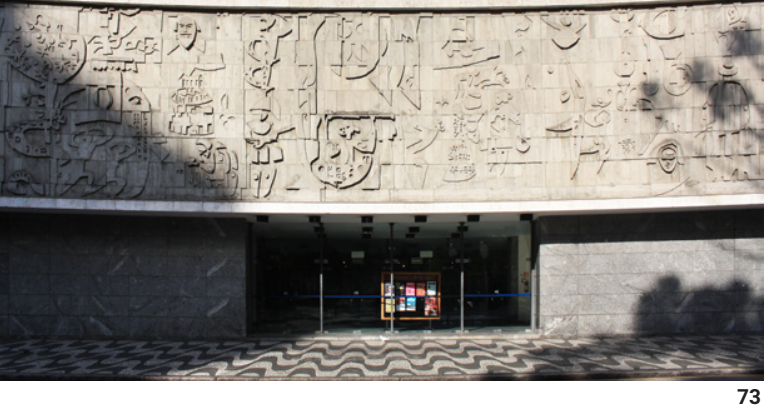




\subsection{MODULAÇÃO, ESTRUTURA E EXPRESSÃO}

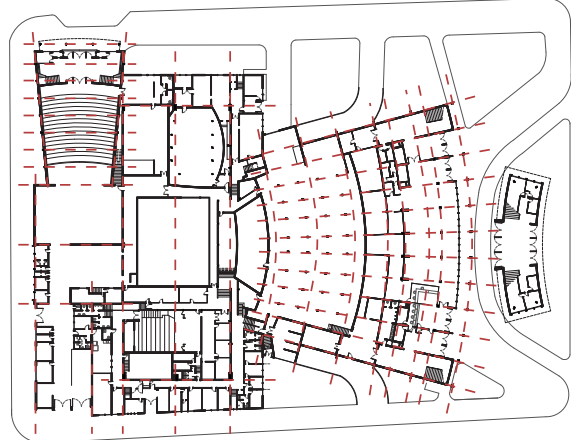

Térreo - Eixos estruturais

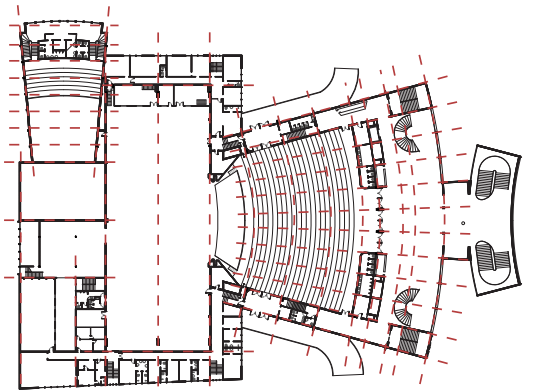

Plateia - Eixos estruturais

\section{Organização espacial}

O edifício se ordena a partir da dimensão do palco e da visibilidade do mesmo. Os eixos de organização do desenho do auditório partem radialmente do centro, ao fundo do palco, até o final da plateia. Abre-se uma estrutura modular radial (com centro à 49,82 metros atrás do centro do palco) a partir das extremidades da plateia que, ao final, na fachada principal, possui dimensões de 5,33 metros. Este módulo corresponde tanto à largura das empenas laterais como da distância entre os nove módulos de esquadrias da elevação do foyer. Radialmente, essas dimensões organizam todos os acessos do foyer à plateia, os módulos de elevadores e as cabines centrais de projeção e controle. Os revestimentos e as posições dos componentes de iluminação artificial também são pautados por esta malha modular concêntrica.

As estruturas transversais acompanham a redução do volume da plateia em direção à caixa cênica e distanciam-se num módulo de 7,93 metros, medida que organiza as escadarias, banheiros e camarotes nessas áreas. Treliças metálicas vencem o vão sobre a plateia. No auditório médio, a estrutura comporta-se de forma semelhante através de sucessivos pórticos a cada 3,60 metros, que diminuem o seu vão ao aproximar-se do palco.

Os três arcos que estruturam o vão máximo de 56 metros do palco principal, distanciam-se de 11 metros e possuem uma altura máxima de 41 metros quando medida do nível do mecanismo do palco, no subsolo. Partindo dos arcos, tirantes sustentam plataformas 10 metros acima do palco. Este nível de apoio às atividades de cena, percorre todo o perímetro do arco com exceção da boca de apresentação. Nas demais áreas perimetrais, os ambientes organizam-se através das dimensões derivadas do próprio arco (11 por 56 metros)

\section{Composição geométrica e desenho da estrutura}

É possível ler o Teatro Guaíra como um complexo que abriga um conjunto de variadas formas 
independentes, porém justapostas. Dessa forma, pode-se dizer que esta é uma obra única na trajetória de um engenheiro-arquiteto que priorizou formas mais regulares e monolíticas ao longo da carreira. A influência da arquitetura carioca é percebida em projetos como o Grupo Escolar Tiradentes (1952) principalmente através dos arcos estruturantes e do volume do auditório, que não chegou a ser executado. No Auditório da Reitoria da UFPR (1955) há possibilidades de se traçar paralelos com o Teatro Municipal de Belo Horizonte (1943) de Oscar Niemeyer através do uso da estrutura porticada, solução também utilizada no bloco do Guairinha. No entanto, a diferença é que são blocos dispostos separadamente na escola e um monobloco no auditório da reitoria. No Guaíra, a relação das formas e suas conexões trabalham de modo compositivo e funcional ao mesmo tempo. Tanto a disposição volumétrica como a utilização do arco parabólico podem ter sofrido influência do Palácio dos Soviets (Le Corbusier, 1931) (GNOATO, 2009, p.116) Todavia, é através da projeção em duas dimensões da implantação que as propostas mais se aproximam, principalmente quando analisada uma das versões preliminares pensada por Le Corbusier (figuras 75 e 76)

"O uso de arcos parabólicos para vencer grandes vãos encontrase entre as conquistas tecnológicas promovidas pelos engenheiros

no início do século XX, como se observa no Hangar para Aviões (1916) em Orly, de Eugène Freyssinet (1879-1963). A transposição do desenho de grandes estruturas para outros programas era uma atitude comum para os arquitetos do Movimento Moderno, como aconteceu com Le Corbusier e Meister." (SUTIL; GNOATO, 2004, p.61)

Não se pode afirmar, no entanto, que as relações dos volumes possuem vínculos matemáticos de proporção entre si. As dimensões do complexo, reduzidas e mais apertadas no novo terreno,
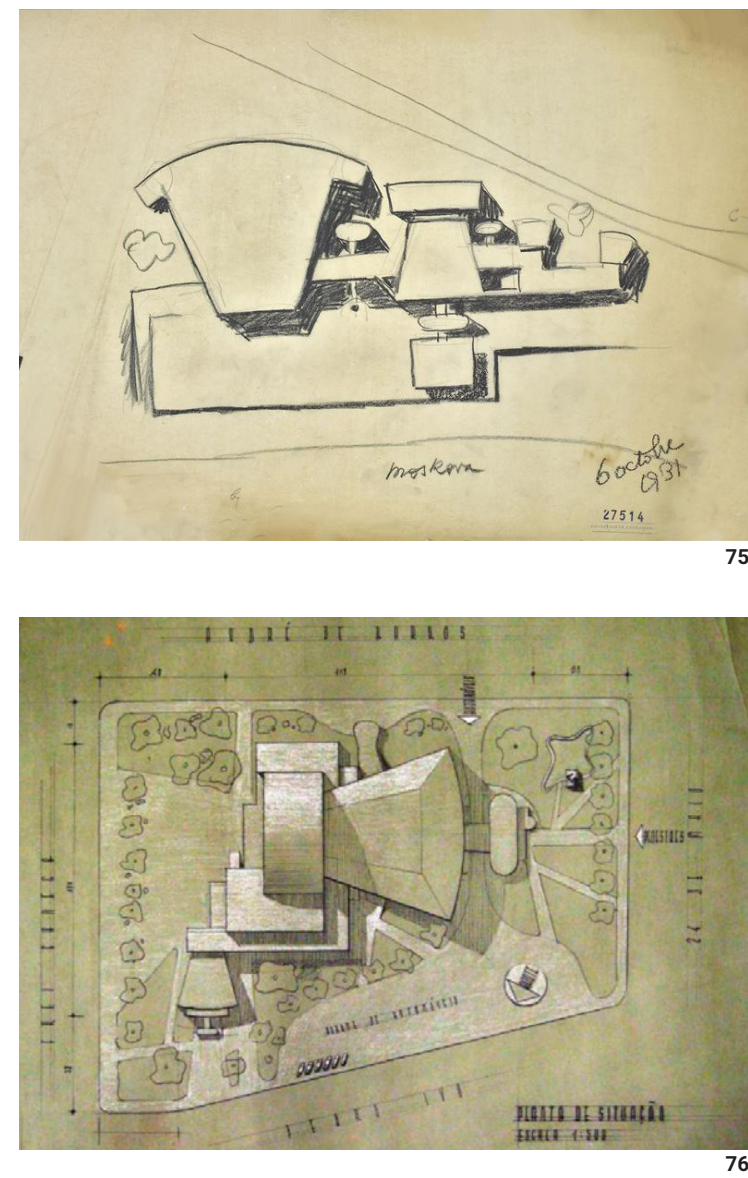

Figura 75 (acima): Uma des variacões de implantação do Palácio dos Soviets (1931) de Le Corbusier. Disponivel em: <https:// thecharnelhouse.org/tag/palace-of-the-soviets>. Acesso em: 14.out.2018

Figura 76 (abaixo): Implantaç̃o do Teatro Guaíra em 1948 Fonte: Acervo Rubens Meister. 
Figura 77 (acima): 0 arco de uma das extremidades da caixa cênica em concreto e o central em aço travados transversal mente pelas treliças metálicas. Fonte: Acervo Rubens Meister.

Figura 78 (abaixo): Prancha do projeto executivo com o detalhamento do arco central. Fonte: Acervo Rubens Meister.
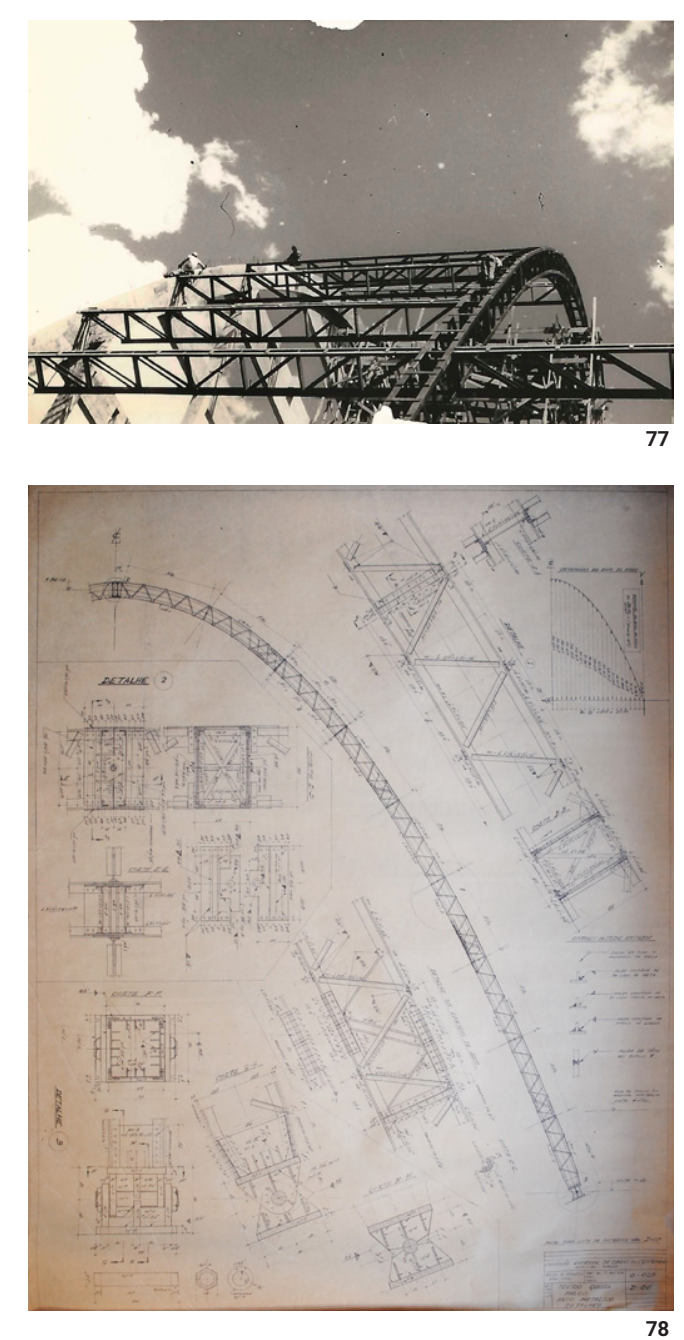

são guiadas pela caixa cênica. É este bloco em arco parabólico o de maior destaque do complexo. Com uma sucessão de três arcos estruturais (dois das extremas em concreto e o central metálico triarticulado e revestido por concreto) travados por vigas treliçadas metálicas (figura 77 e 78), o volume projeta-se com uma altura máxima de 41 metros e 32 metros a parti do piso palco, que possibilitam um vão de 56 metros, profundidade de 22 metros e uma boca de cena com 18 metros de largura. "Embaixo é inteiramente livre, ou seja, na hora em que eu quiser introduzir a mecanização do palco pode-se usar o que tiver, o que for mais compatível com a época." (MEISTER in VIANNA et al., 1999, p.10). O arranque do arco central foi desenvolvido em cima de uma dobradiça que "assenta e supre a movimentação da estrutura em relação ao solo" (NISSEN et al., 2016, p.61).

"As principais dificuldades de construir o teatro foram: o terreno ruim - um verdadeiro banhado, as fundações que deram muito trabalho e a estrutura do arco central. (...) O maior desafio foi sem dúvida a base do arco central do grande auditório, pois a concentração de carga do palco é imensa. As tubulações, as dobradiças e armação eram coisas extraordinárias para a época.”

(LEPCA, 2016 apud NISSEN et al., 2016, p.127)

Tanto o sistema foyer/plateia do grande auditório (Bento Munhoz da Rocha Netto) como do médio (Salvador Ferrante) são abrigados em volumes que possuem suas dimensões reduzidas conforme aproximam-se do palco. No caso dos dois auditórios, o centro do raio está condicionado à visualidade do público, o qual guia as dimensões dos balcões da plateia e do foyer. Os demais volumes periféricos ao da caixa cênica principal são ortogonais e regulares somados de uma inclinação na direção da esquina norte para ganho de área. Tangenciando internamente o arco parabólico, a caixa cênica do Auditório Salvador Ferrante se sobressai 


$$
\text { Solos nos }
$$



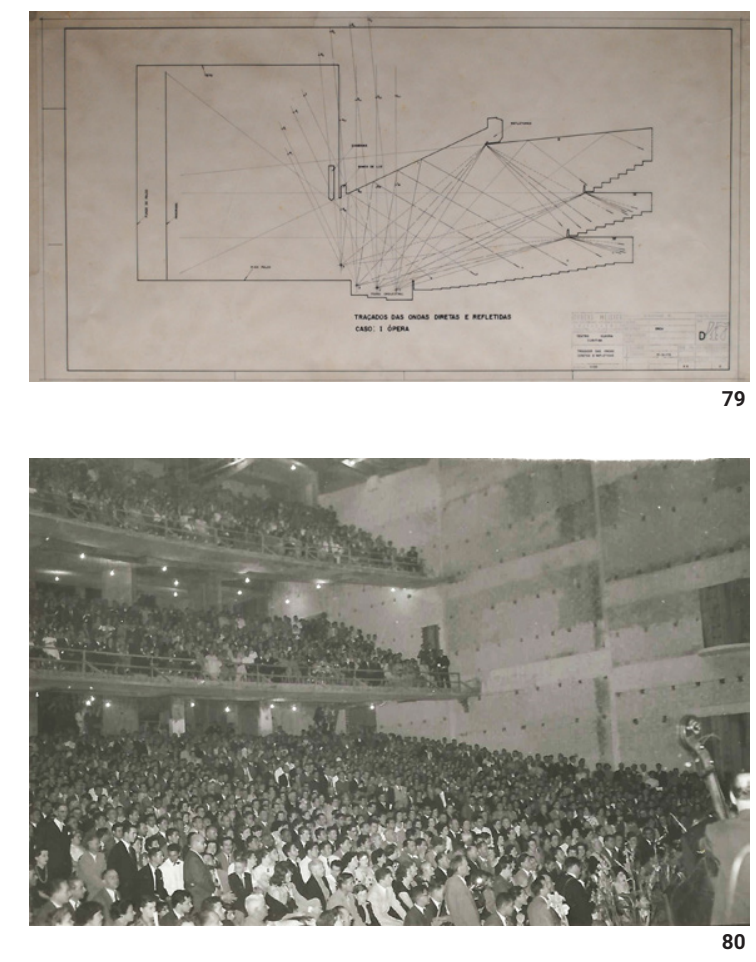

Na página anterior: As formas justapostas que compõem plasticamente o complexo. Fonte: Desenho desenvolvido pelo autor

Figura 79 (acima): Estudos de Rubens Meister dos traçados das ondas acústicas no grande auditório. Fonte: Acervo Rubens Meister.

Figura 80 (abaixo): Orquestra Sinfônica. Brasileira se apresentando com o grande auditório do Teatro Guaira ainda em obras em 1954. Fonte: Acervo Rubens Meister. verticalmente aos fundos do complexo. Essa disposição em setores permitiu que o "Guairinha" (auditório médio) pudesse ser inaugurado antes do grande auditório (que viria a sofrer pela falta de recursos para finalização da obra) e funcionasse independentemente do restante.

O formato e a disposição interna do grande auditório também foram projetados tendo em vista as questões acústicas, estudadas minuciosamente por Meister (figura 79). Antes mesmo da aplicação dos materiais internamente, o teatro já apresentava uma sonoridade satisfatória. Ela foi atestada pelo arquiteto durante o concerto da Orquestra Sinfônica Brasileira feita nas Comemorações do Centenário de Emancipação Política do Paraná (figura 80).

"A obra estava na estrutura, não tinha cadeira, estava só no concreto. (...) No concerto com a orquestra sinfônica, havia só concreto, e a acústica estava boa. Mandei alisar todas as paredes do auditório de concreto e deu resultado." (MEISTER in VIANNA et al., 1999, p.12 e 13)

\section{Materialidade}

Os materiais e texturas são, neste projeto, instrumentos essenciais da composição. A forte presença do mármore no revestimento externo ganha suporte da luz natural e evidencia as volumetrias circulares das fachadas principais.

O teatro apresenta-se externamente como uma "carapaça" clara de interiores "quentes". O mármore branco sofre algumas rupturas: no painel O Teatro e o Mundo (1969) de Poty Lazzarotto na fachada do volume do saguão de acesso principal (figura 81), no arenito das empenas do Auditório Salvador de Ferrante e no quente da madeira transmitido através das esquadrias - em aço cinza e vidros translúcidos - que conectam o foyer aos espaços externos. No térreo, os pilares e alvenarias também são revestidos por um mármore cinza escuro (por vezes polido, por vezes bruto) que soltam os volumes superiores. Os blocos regulares de apoio/administração 
são revestidos em aglomerados tipo granilite em duas tonalidades próximas às cores dos mármores. Essa gama de revestimentos transparece o uso e nobreza de cada setor e separa o conjunto em distintas unidades, que se erguem em meio a jardins gramados e passeios desenhados por pedras portuguesas.

Internamente, o foyer no pavimento plateia possui o piso revestido pelo mesmo mármore cinza da fachada enquanto os balcões superiores são em carpete vermelho, o mesmo utilizado no interior dos auditórios. As paredes laterais do foyer são em massa texturizada e preenchidas por cubos em madeira (originalmente murais estavam previstos para cada uma das paredes) O acesso para a plateia ocorre em meio à pilares revestidos com mármore branco e ripados de madeira no sentido vertical. Os tetos do saguão e da plateia do grande auditório são acabados por placas em madeira intercaladas por fiadas de luminárias, pautadas pelo módulo radial e inclinadas conforme o tratamento dado às ondas acústicas neste último. No foyer os forros são em tabuas de madeira (cortadas em "quatro águas") intercaladas e dispostas no sentido longitudinal. Abaixo dos balcões. nos dois auditórios, os forros são em tábuas madeira lisas e planas. As paredes laterais são em concreto alisado e pintadas na cor terracota. Atrás do palco uma viga de concreto na mesma largura da boca de cena, sustenta uma porta corta-fogo suspensa que veio a receber pintura de Poty Lazzarotto.

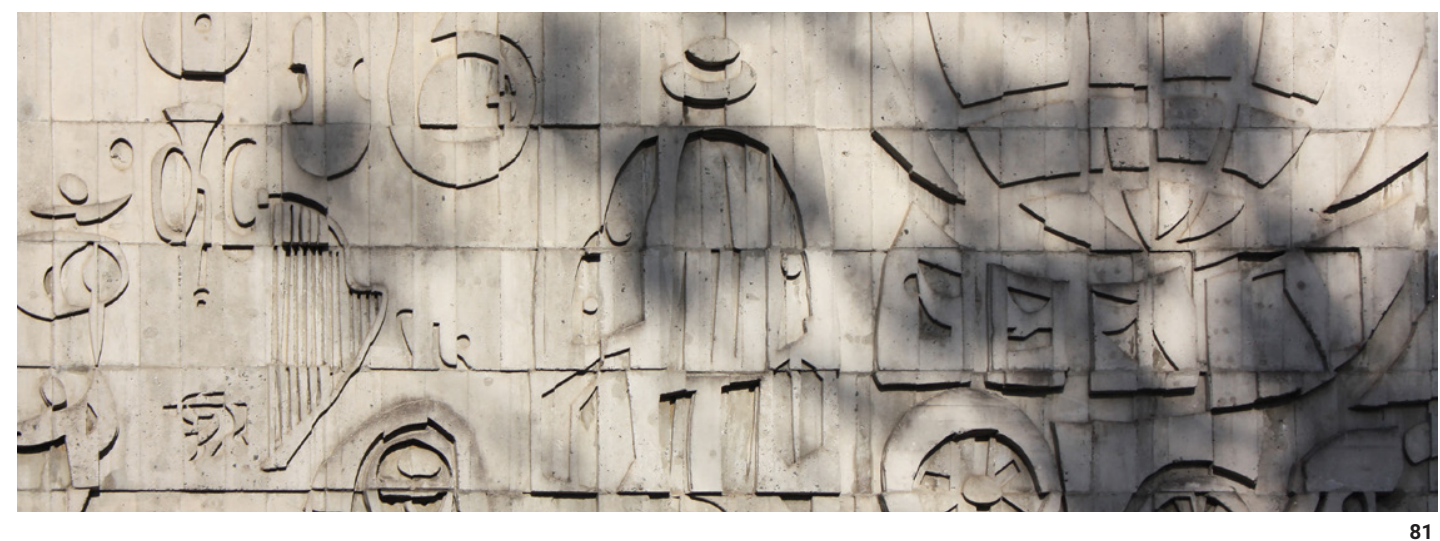

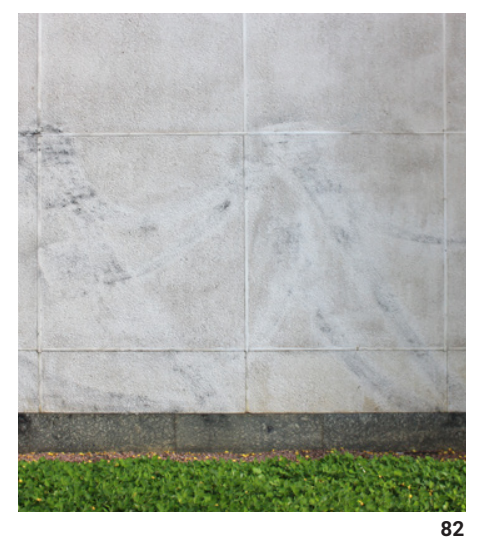

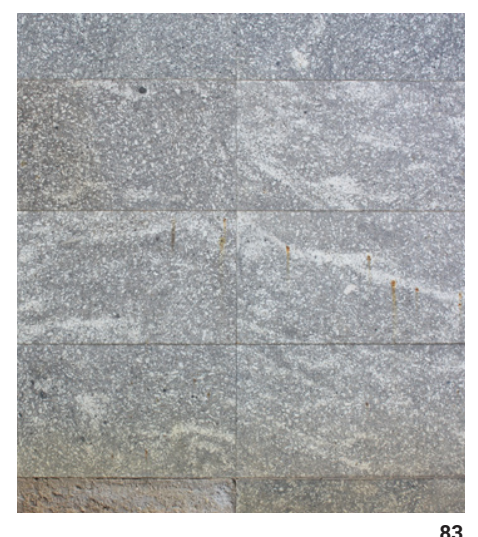

83

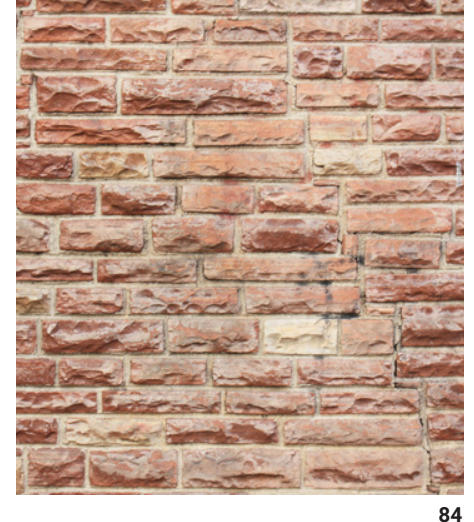

Figuras 81, 82, 83 e 84: A materialidade aplicada às fachadas do teatro. 0 mural de concreto de Poty Lazzarotto, o mármore branco, o mármore escuro e o arenito respectivamente. Fonte: Acervo do autor

Figuras 85, 86, 87,88 e 89 (página seguinte): A relação entre os materiais e texturas nas fachadas e foyer do grande auditório. Fonte: Acervo do autor. 

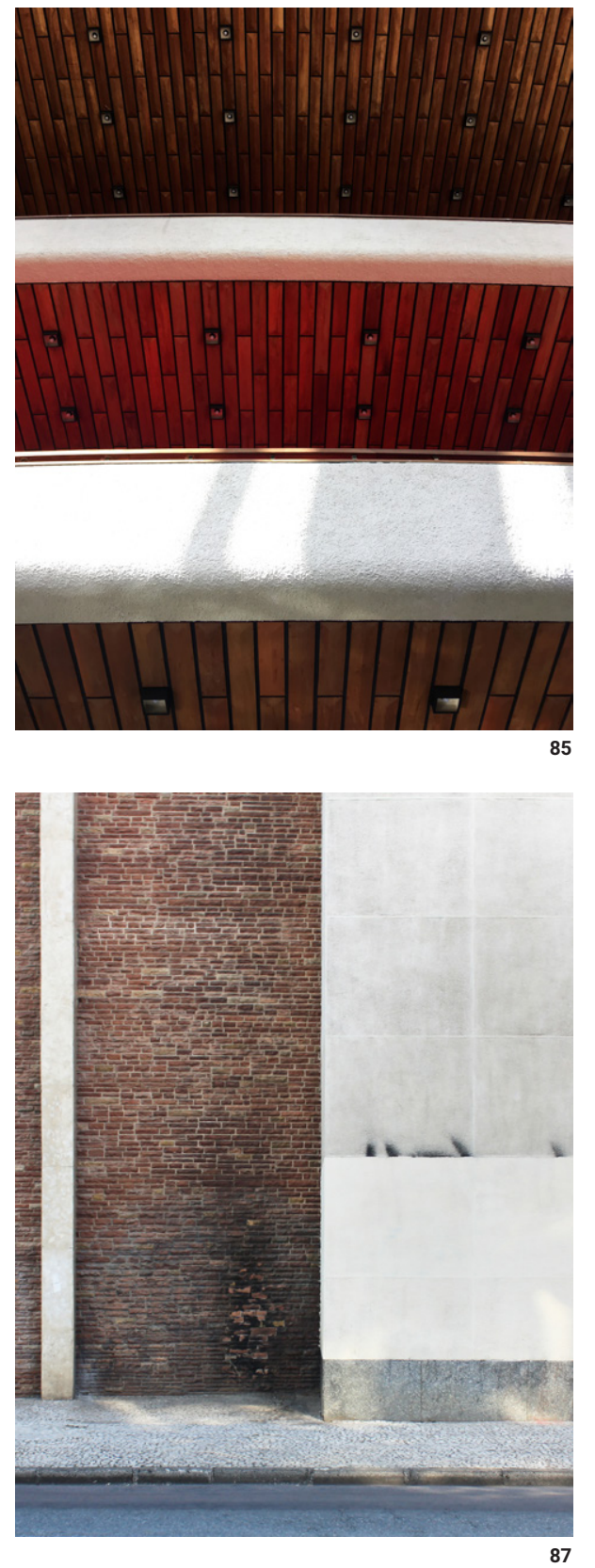
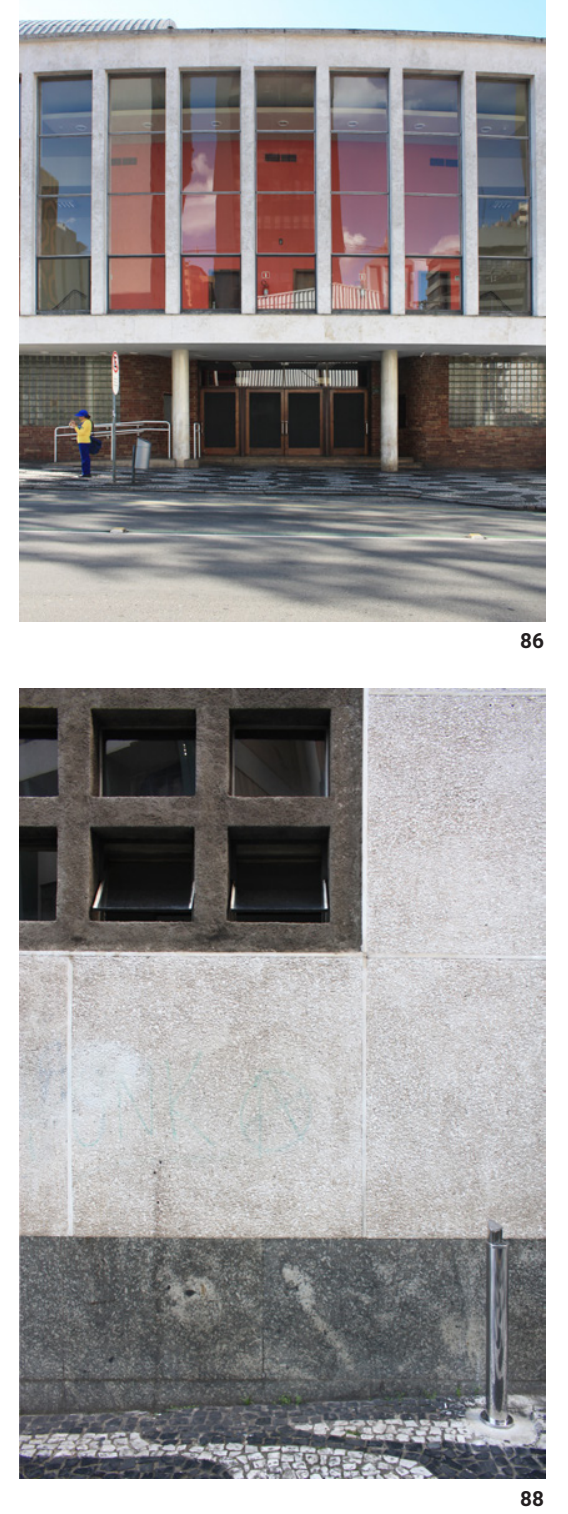

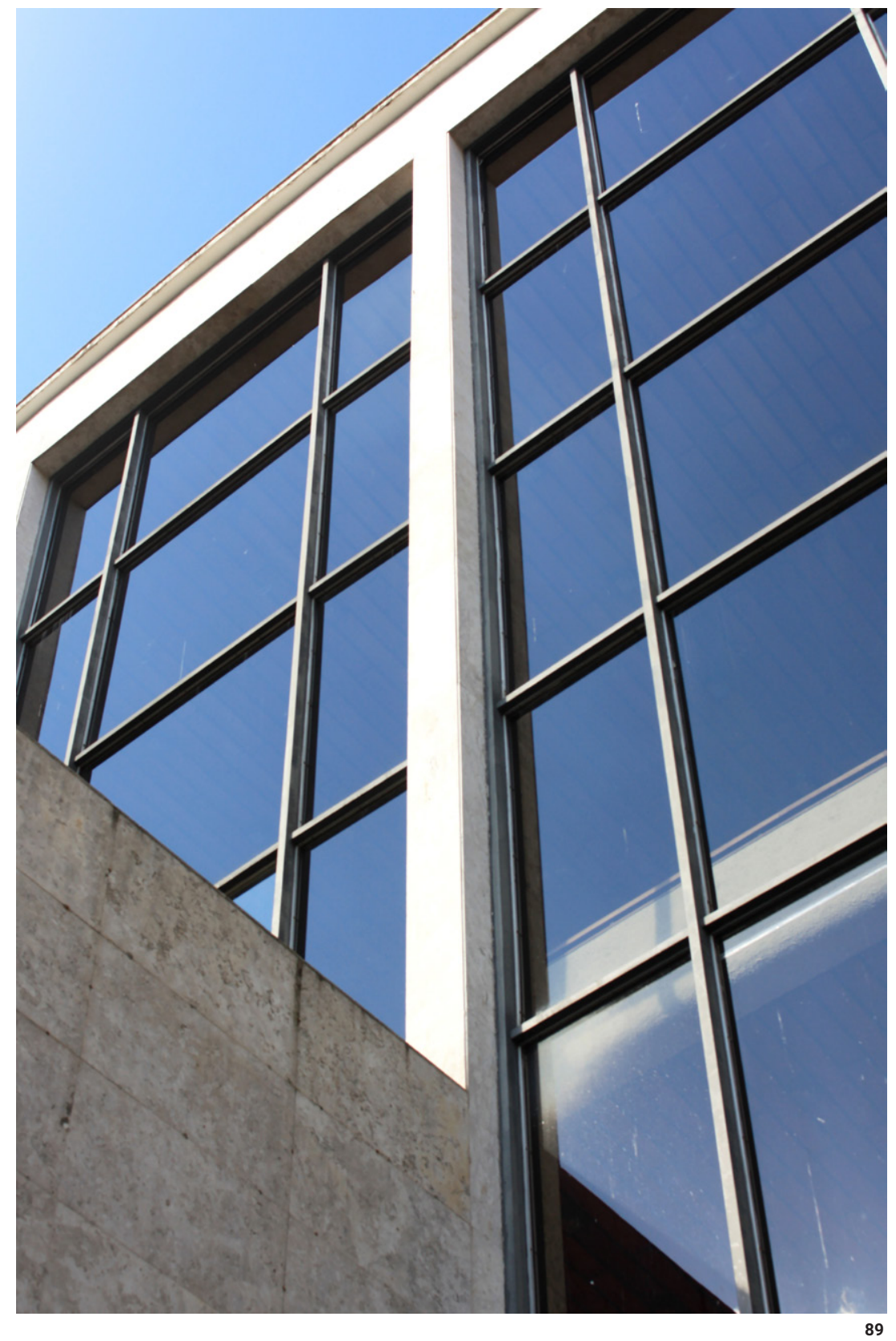




\section{Conclusões}

No contexto geral da carreira de Rubens Meister, o Teatro Guaíra é a pedra fundamental. $\mathrm{O}$ desenho do prédio traz à tona um arquiteto ainda com olhos fortemente voltados para Le Corbusier e o Rio de Janeiro, algo que durou pouco na sua trajetória. Ainda assim, o Teatro Guaíra é a obra que traduz Meister e que, ao mesmo tempo, mostra muito dos seus princípios norteadores, presentes até o final da sua vida profissional. É uma edifício que representa parte da cultura de Curitiba e do Paraná e uma parte importante da história do seu autor. Seu escritório funcionou lá por alguns anos, estudou na Universidade do Paraná (em frente ao teatro) e em certo momento, morou na Praça Santos Andrade durante as obras (NISSEN et al., 2016, p.96).

"Eu tive muitas alegrias, eu não sei qual é a maior. O Guaíra inaugurado, talvez... Quando se vence um concurso é uma grande alegria, uma obra concluída que funciona bem, uma satisfação não

só estética."

(MEISTER in VIANNA et al., 1999, p.19)

Meister estabeleceu, com este projeto, um diálogo de aproximação e distanciamento do contexto. Adaptou-o do concurso que previa o projeto em outro sítio e o voltou para a Praça Santos Andrade e para o prédio histórico da Universidade Federal do Paraná. Manteve a simetria e criou uma relação de contraste gerando, assim, um equilíbrio ao contrapor diferentes linguagens.

Quanto aos princípios compositivos, Meister deu espaço a formas curvas em seu primeiro projeto como profissional ante à ortogonalidade característica dos períodos subsequentes. Ainda assim, desenvolveu vínculos diretos com a estrutura e questões técnicas sem cair no 
figurativo. A forma está aqui vinculada às condicionantes do problema arquitetônico, como síntese do programa, da estrutura, da técnica e do local.

A concepção de um teatro incorpora diversos aspectos técnicos, os quais exigiram constantes pesquisas e aprofundamentos de um jovem engenheiro-arquiteto "isolado" em uma cidade ainda provinciana. A estrutura, a funcionalidade, as circulações, a acústica e visibilidade adaptam-se às diversas categorias de apresentações, sendo que para cada uma delas há um espaço de apoio respectivo. Todas estas questões buscam propiciar bom desempenho e conforto para as atividades que ali ocorrem. Estes espaços são, sobretudo, envoltos pelas formas e soluções construtivas através de uma estrutura relacional que servem à sua finalidade e conferem identidade ao episódio arquitetônico.

O valor desta obra é reconhecido e de grande relevância para a arquitetura moderna paranaense, sendo a mesma tombada em 2003 pelo Patrimônio Cultural do Estado do Paraná sob a seguinte justificativa:

"Com sua construção iniciada no contexto das obras que fizeram em Curitiba por ocasião da comemoração do centenário da Emancipação Política do Paraná, o Teatro Guaíra veio a compor, juntamente com a Biblioteca Pública do Paraná, o Centro Cívico, a Praça Dezenove de Dezembro e o Colégio Estadual do Paraná, talvez o que se possa qualificar como o mais importante conjunto arquitetônico da histórica paranaense. Significam também o momento em que o Paraná se insere nos debates sobre a grande arquitetura moderna brasileira, marcando o ponto inicial de um debate entre o moderno e o tradicional que influenciaria os caminhos da arte no Paraná.

Iniciado em 1952, com seu primeiro auditório - Salvador de 
Ferrante - inaugurado em 19 de dezembro de 1954, o Teatro Guaíra, tem como autor de seu projeto Rubens Meister. Construído em fases, considera-se que sua conclusão deu-se em 1974, quando da inauguração de seu grande auditório - Bento Munhoz da Rocha

Neto.

O tombamento do Teatro Guaíra significa o reconhecimento

de sua indiscutível qualidade arquitetônica, de sua concepção singular, e de sua importância, no rol das edificações voltadas às artes cênicas, que transcende os limites do Paraná. Também é, com certeza, uma bela homenagem, a todos os paranaenses, pelos 150

anos de emancipação."

(Secretaria da Comunicação Social e da Cultura - Patrimônio

Cultural do Estado do Paraná, 2003)

O Teatro Guaíra é a materialização dos pressupostos modernos que estavam sendo difundidos pelas vanguardas arquitetônicas em diferentes partes do globo. Esses ideais estavam nas revistas, nos livros e também no olhar atento de Rubens Meister. Em 1950, Curitiba tinha em torno de 180.000 habitantes morando em pequenas chácaras, casas, sobrados e raras edificações acima de dois pavimentos que eram dotados de uma linguagem arquitetônica bem familiar. Foi um risco tomado pelo engenheiro recém formado e pelo governador Bento Munhoz da Rocha. Aos moldes das primeiras aparições de Kirschgässner e Artigas, mas dotado de maior relevância e expectativa, o teatro oficial do estado ergueu-se a partir de uma arquitetura que ainda era desconhecida ou não compreendida pelo público. Um risco certeiro, que logo passou da estranheza e desconfiança para a aceitação e, com o tempo, para o orgulho. 


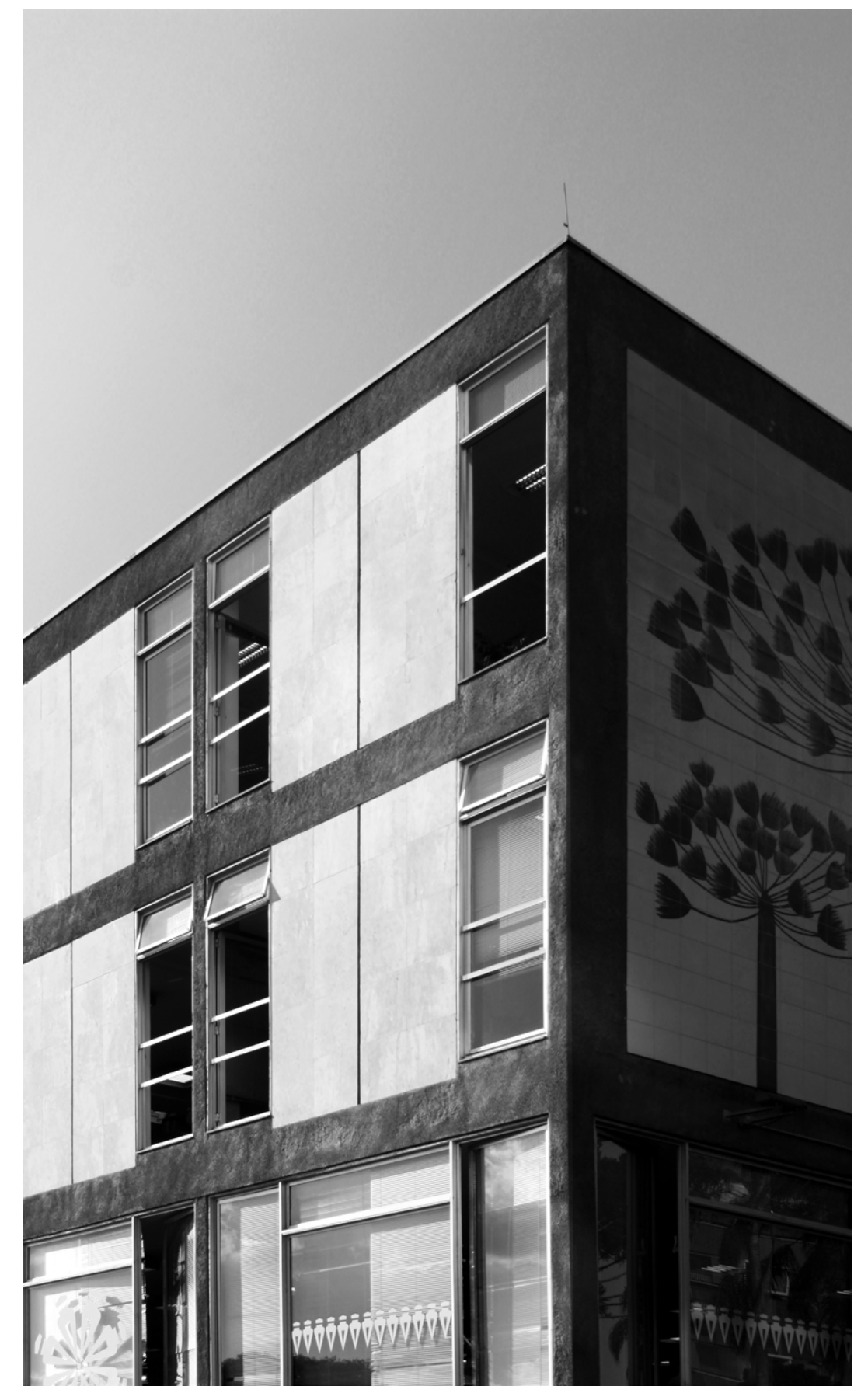


Palácio 29 de Março 


\section{Introdução}

Após a participação no concurso para o Teatro Guaíra em 1948 e o desenvolvimento do projeto a partir de 1951, Rubens Meister ganhou notoriedade como projetista de edificações para os governos municipais e estaduais. O poder púlico, no período, respaldou-se na prerrogativa de transmitir uma visão de progresso e modernidade através de novas obras. Meister, dessa forma, tornou-se um dos principais agentes na transformação desse cenário.

O Palácio 29 de Março surge com a necessidade da Prefeitura Municipal de Curitiba de expandir e unificar as suas atividades em uma nova sede, localizada em um terreno anexo ao novo e moderno Centro Cívico do Estado do Paraná. Até então, o que se tinha como ideia de espaço físico relacionado ao poder municipal, encontrava-se materializado em uma edificação eclética, no centro histórico da cidade.

A precisão, clareza e a eficiência são características intrínsecas à obra do engenheiroarquiteto, especialmente na primeira metade de sua aitividade profissional. O poder público tinha como ideal transmitir qualidades como estas aos habitantes de Curitiba e encontrou na arquitetura de Rubens Meister a melhor forma de exprimi-las.

Dentre os projetos públicos realizados até o Palácio 29 de Março (1960), além do Teatro Guaíra, destacam-se: o Panteão dos Heróis da Lapa (1943), o Grupo Escolar Tiradentes (1951), o Auditório da Reitoria da UFPR (1955), o Centro Politécnico da UFPR (1956) e a Rodoviária de Curitiba (1956). Sendo que apenas este último estava vinculado ao poder municipal. 


\section{Análise de projeto}

\subsection{IMPLANTAÇÃO E RELAÇÃO COM A CIDADE}

\section{Contexto}

A sede da Prefeitura Municipal de Curitiba, que ocupava o edifício do atual Paço da Liberdade desde 1916 (figura 91) na praça Generoso Marques, localizava-se no centro histórico e a menos de duas quadras da Praça Tiradentes (Marco Zero de Curitiba) e da Catedral Basílica (figura 95, 96 e 97$)$

A cidade contou com um intenso crescimento nos anos 1950. Com a necessidade de ampliação e de concentração dos departamentos e serviços do poder municipal (na época muitos dos órgãos estavam situados em diferentes edifícios) o prefeito, General Iberê de Matos, entrou em contato com Rubens Meister para vislumbrar uma nova sede da prefeitura nas imediações do novo Centro Cívico do estado do Paraná (1951), naquele momento parcialmente executado.

O terreno escolhido para implantação, que previa a instalação de um quartel general (XAVIER, 1985, p.10), localizava-se a norte da área central de Curitiba e foi pensado para que fosse agregado ao projeto do Centro Cívico, numa quadra deslocada à sul e no eixo urbano de conexão com a Praça Tiradentes (figura 96 e 97).

"O Plano Agache pretendia situar o palácio para o governo do estado defronte à prefeitura, a 1.800 metros de distância. A prefeitura do Plano Agache não seria construída. O Centro Cívico recebeu outro projeto." (DUDEQUE, 2010, p. 102)

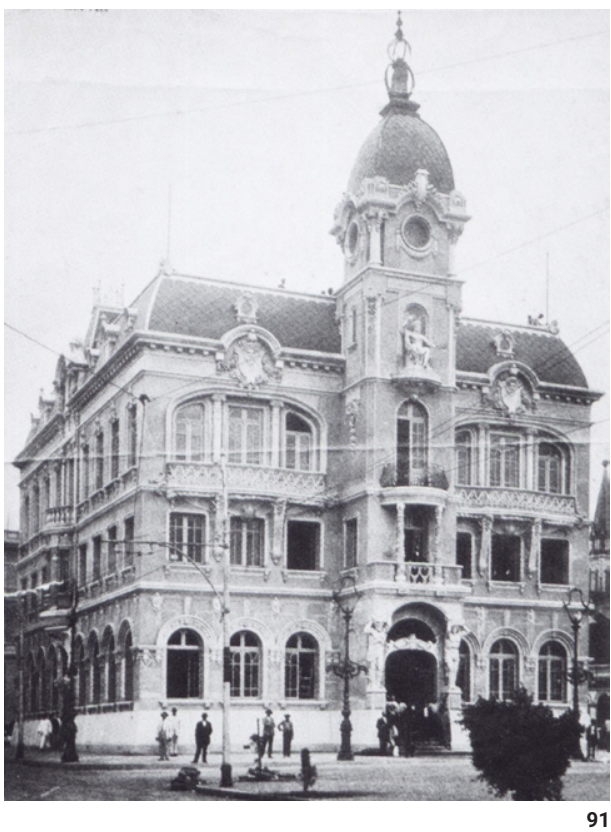

Figura 91: O Paço da Liberdade, onde funcionou a Prefeitura Municipal de Curitiba localizado na Praca Generoso Marques. Data desconhecida. Fonte: Instituto de Pesquisa e Planejamento Urbano de Curitiba (IPPUC) 
Figura 92: A proposta do Plano Agache (1943) para o setor do Centro Cívico do Estado do Paraná. Fonte: CASTRO, 2011 p.42.

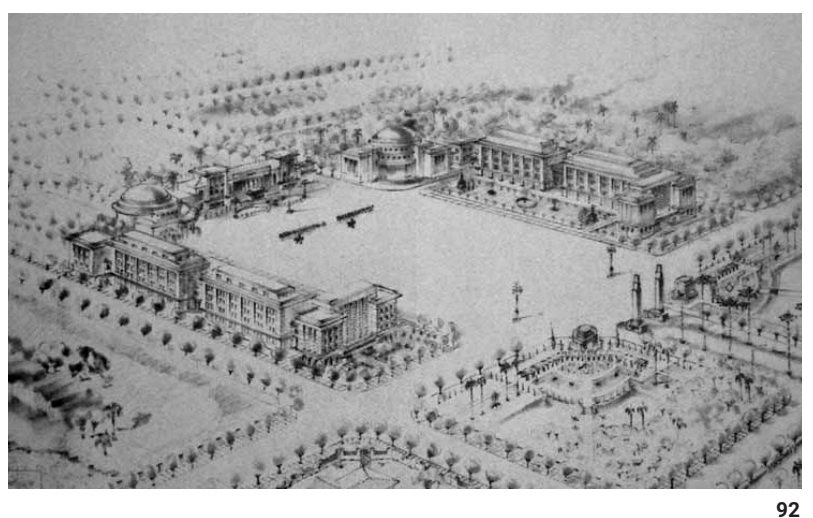

O local e projeto do Centro Cívico foi proposto primeiramente pelo urbanista Alfred Agache no seu plano para Curitiba (Plano Agache 1943). O estudo foi retomado em 1950 sob uma nova ótica, a pedidos do governador Bento Munhoz da Rocha, visando as Comemorações do Centenário de Emancipação Política do Paraná (1953).

Foi criada a Comissão Especial de Obras do Centenário (CEOC) e Munhoz da Rocha convidou o arquiteto David Xavier Azambuja que, junto a Olavo Redig de Campos, Sérgio Rodrigues e Flávio Regis do Nascimento desenvolveram um novo projeto arquitetônico e urbanístico. A nova proposta, seguiu alguns pensamentos de Agache para o local, onde o urbanista previa uma praça cívica envolta de edificações de estilo eclético com o edifício do governo estadual em seu centro (figuras 92 e 93). Apesar da transformação para uma versão moderna, a praça central e a localização da sede do governo, prevista no plano, foram mantidas. O projeto, no entanto, sofreu diversas modificações em sua execução, desde as edificações até o desenho do espaço público. A Avenida Cândido de Abreu, que possui seu início na Praça Tiradentes (Marco Zero de Curitiba), foi continuada e executada sobre a praça cívica antes pensada por Agache (e David Azambuja), acabando em frente ao Palácio Iguaçu (1951) e dividindo o espaço público em dois.

O território, previamente dominado por residências, fazia parte do bairro Ahú (loca conhecido como Ahú de Baixo) o qual esteve, em 1952, com o início das obras, sob o efeito das transformações para uma nova e moderna realidade. É interessante observar na figura 96, a concomitância na construção do Centro Cívico do Estado do Paraná (1951) e do Teatro Guaíra $(1948 / 1951)$

Novas áreas e edifícios foram, com o tempo, incorporadas ao plano do Centro Cívico do Estado Do Paraná. Dentre elas, uma faixa à norte, que compreende a região do Edifício Castello Branco/Museu Oscar Niemeyer (1971/2001) e outra à sul, onde situa-se o Palácio 29 de Março. Em 1977 foi realizado um projeto paisagístico por Roberto Burle Marx em que a praça cívica era recuperada, sendo que o desenho compreendia todo o limite territorial do plano original somado dessas áreas anexas (GNOATO, 2009, p. 75). 

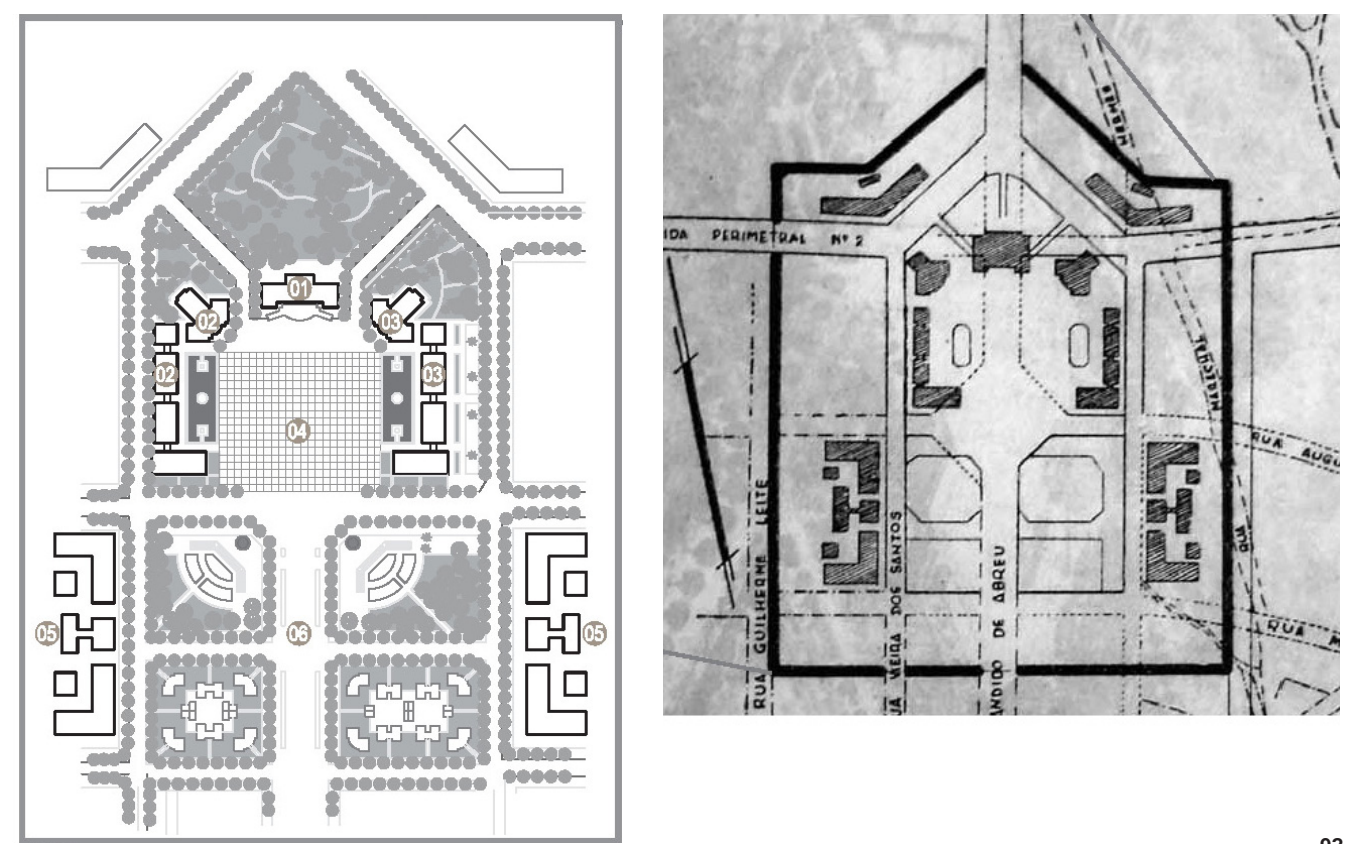

(1)

93
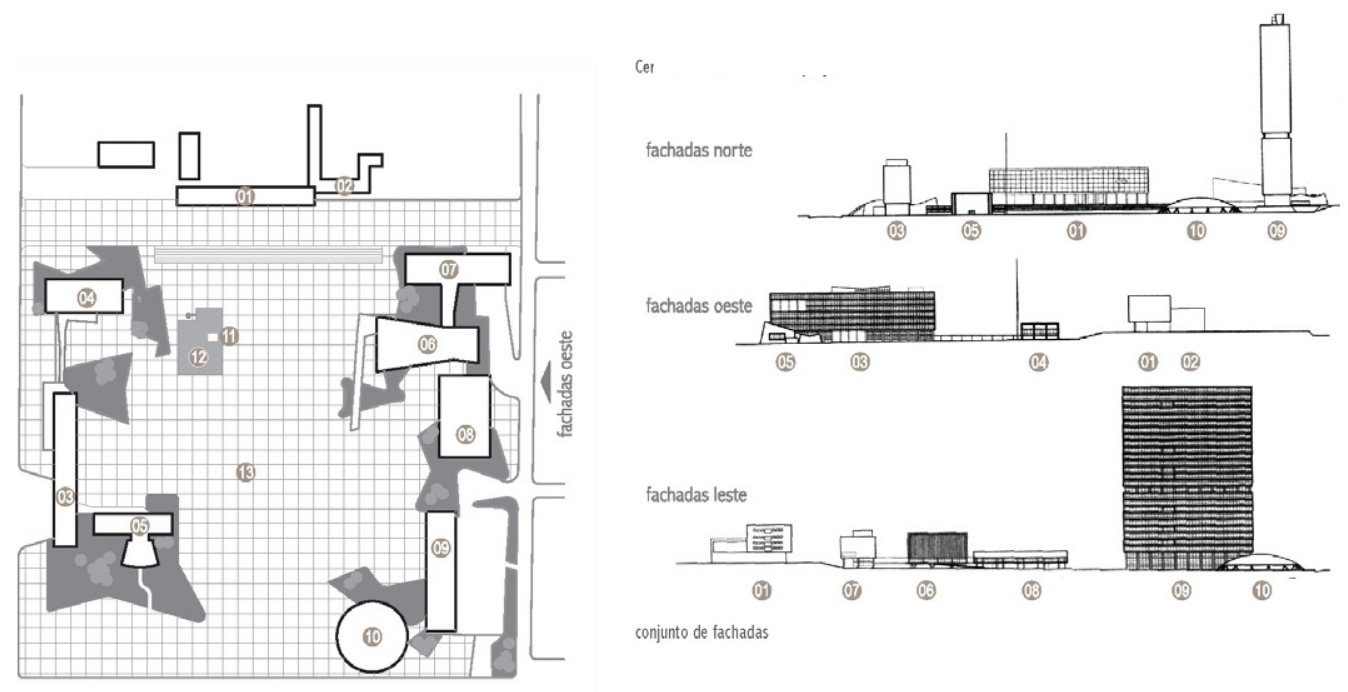

conjunto de fachadas

13 Praça
Centro Cívico - Plano Agache 1943

01 Palácio do Governo

02 Poder Legislativo

03 Poder Judiciário

04 Praça

05 Secretarias

06 Avenida Cândido de Abreu

Fiqura 93 (nesta página acima): A propos ta do Plano Agache (1943) para o setor do Centro Cívico do Estado do Paraná. Fonte CASTRO, 2011, p. 42

Figura 94 (nesta página abaixo): 0 projeto de David Azambuja e equipe (1951). Fonte CASTRO, 2011, p. 4

01 Palácio

02 Residência do Governador

03 Palácio da Justiça

04 Tribunal Eleitoral

05 Tribunal do Júri

06 Plenário da Assembleia

07 Secretaria da Assembleia

08 Comissões da Assembleia

09 Secretarias de Estado

10 Pagadoria e Recebedoria

11 Monumento ao Centenáric

12 Espelho d’água

Fiqura 95 (página seguinte à esquerda): Vista aérea parcial de Curitiba em 1935 Fonte Acervo do inst tuto de Pesqusa e Planejamento Urbano de Curitiba (IPPUC) e editado pelo autor.

Figura 96 (página seguinte ao centro) Vista aéree parcial de Curitiba em 1952 destacando a construç do Centro do Centro Civico do Estado do Paraná. Fonte: Acervo do Instituto de Pesquisa e Planejamento Urbano de Curitiba (IPPUC) e editado pelo autor.

Figura 97 (página seguinte à direita): Vista aérea parcial de Curitiba em 2018 Fonte: Google Earth e editado pelo autor 


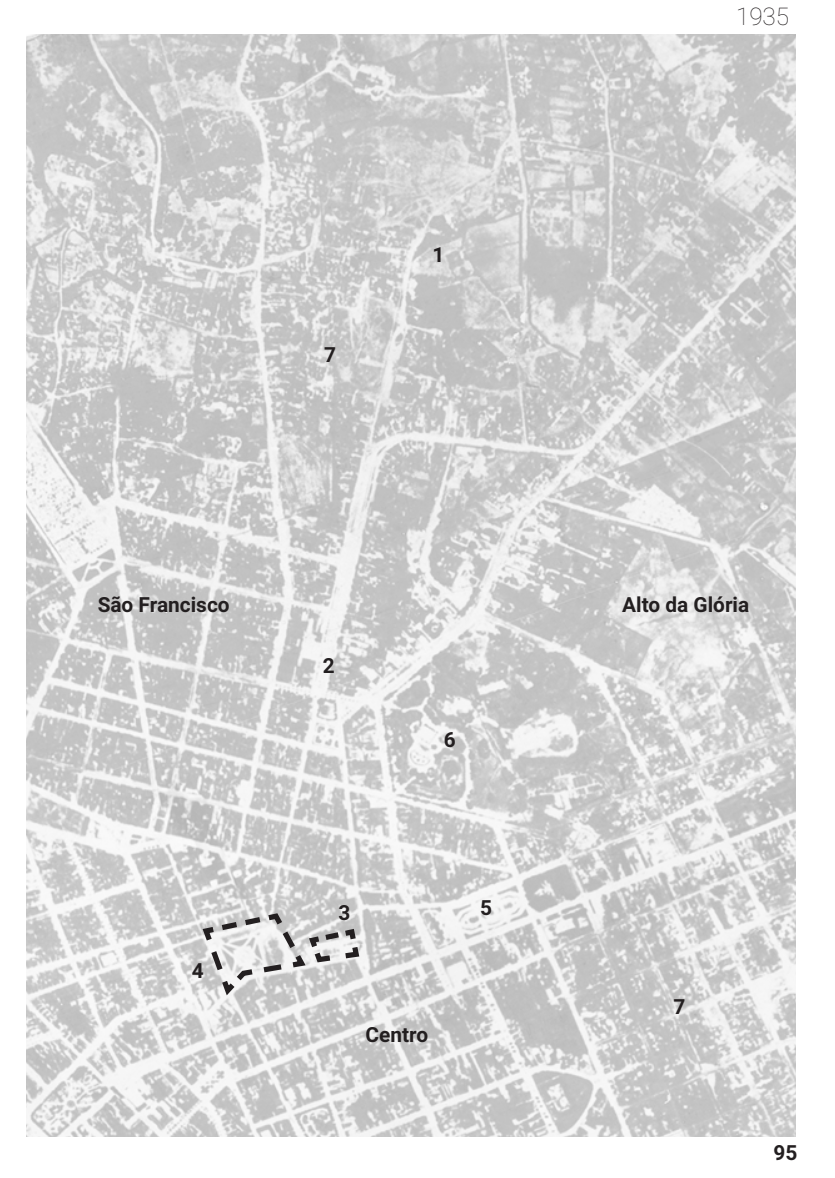

1 Centro Cívico do Estado do Paraná (195-

2 Eixo da Avenida Cândido de Abreu

3 Praça Generoso Marques Paço Municipal de Curitiba (1916-1969)

4 Praça Tiradentes | Catedral Basilica de Curitiba

5 Praça Santos Andrade

6 Passelo Public

8 Palácio 29 de Março

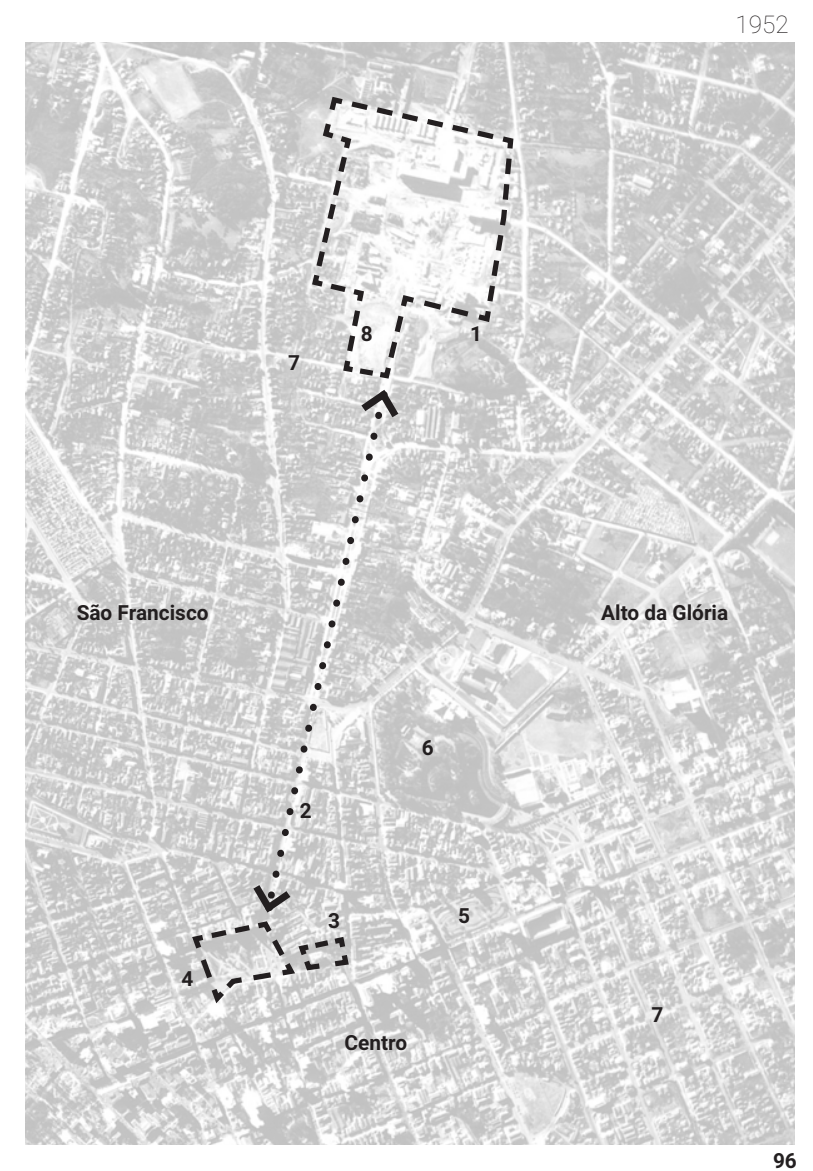

96

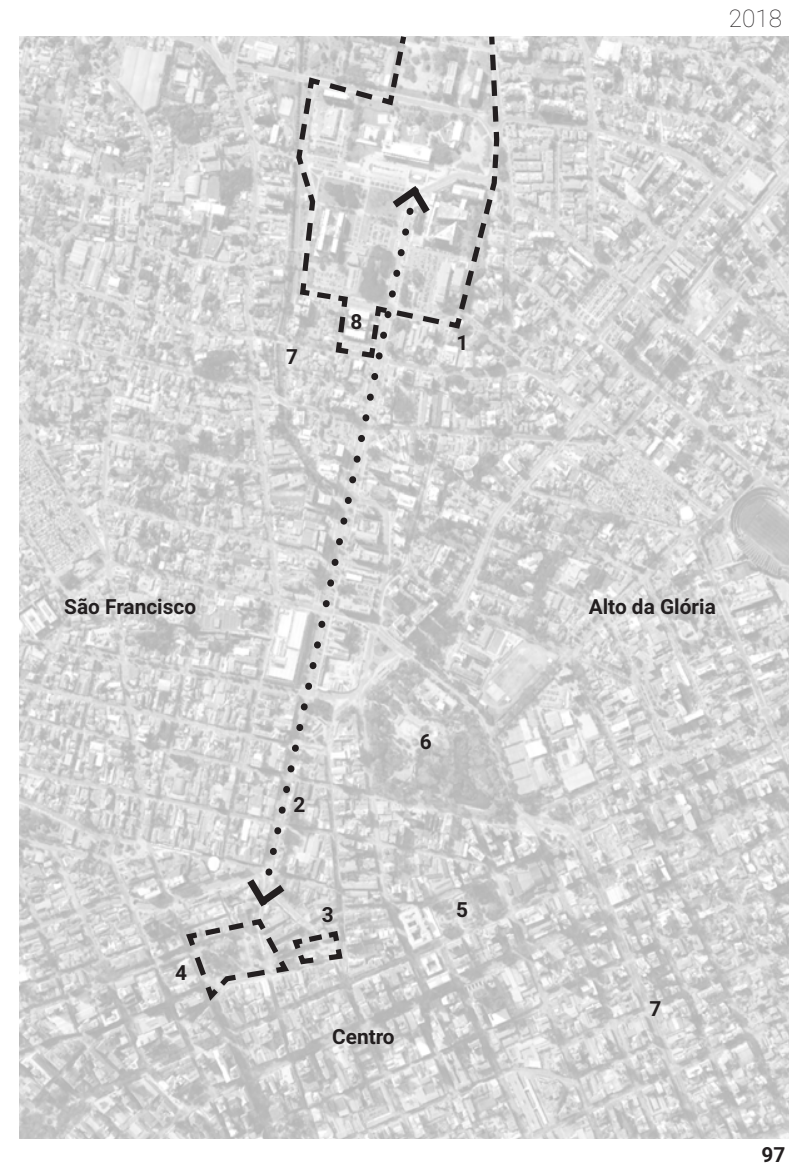

( 
As obras do Palácio 29 de Março tiveram início em 1961 e o edifício foi inaugurado em 1969. O título atribuído ao edifício corresponde ao aniversário da cidade de Curitiba. Assim como boa parte dos edifícios que compõem o plano proposto por Azambuja, o palácio está voltado para a Avenida Cândido de Abreu (figura 98), principal eixo visual e de comunicação entre o centro da cidade e o Centro Cívico (figura 99).

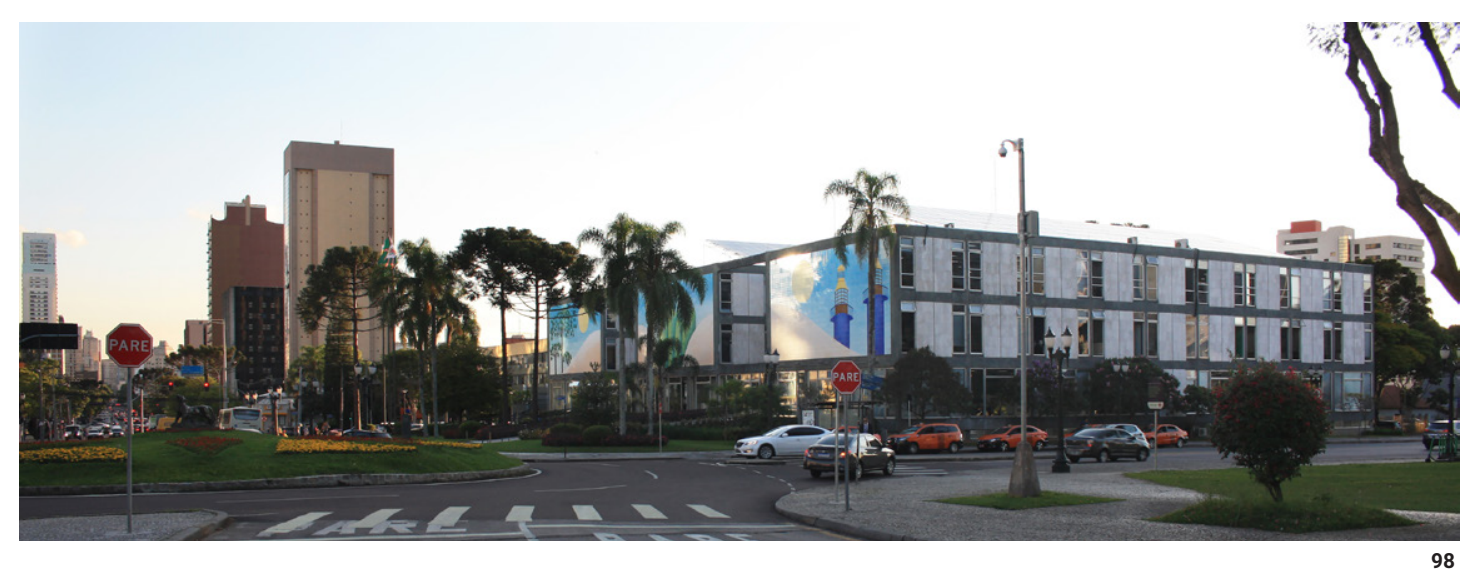

Relação com a paisagem urbana

O terreno destinado ao Palácio 29 de Março consiste em uma quadra retangular de 85 por 98 metros. A oeste, na Rua Papa João XXIII, há pequenas casas - em lotes previamente consolidados ao plano do Centro Cívico - dominadas em sua maioria por pequenos comércios. A sul, do outro lado da Rua Lysimaco Ferreira da Costa, encontram-se edificações de uma agência bancária, um centro judiciário e um edifício residencial de baixo gabarito. No terreno à leste, também na Avenida Cândido de Abreu, localiza-se o prédio do Poder Judiciário e, ao norte, a Praça Nossa Senhora de Salete, limitada pela Rua Ernâni Santiago de Oliveira e localizada no centro do projeto do Centro Cívico.

O projeto de Meister, junto às demais edificações do plano, formam um conjunto que se destaca em meio ao território construído dos espaços urbanos limítrofes (figura 100).
Figuras 98 (esquerda): 0 Palácio 29 de Março e o eixo da Avenida Cândido de Abreu. Fonte: Acervo do autor. Fiqura 99 (acima à direita): O Palácio Iguaçu no final do eixo da Avenida Cândido de Abreu. Fonte: Acervo do autor. Figura 100 (abaixo): Vista aérea do Centro Cívico Disponivel em < <ttp://curitiba. pr.gov.br> e editado pelo autor.
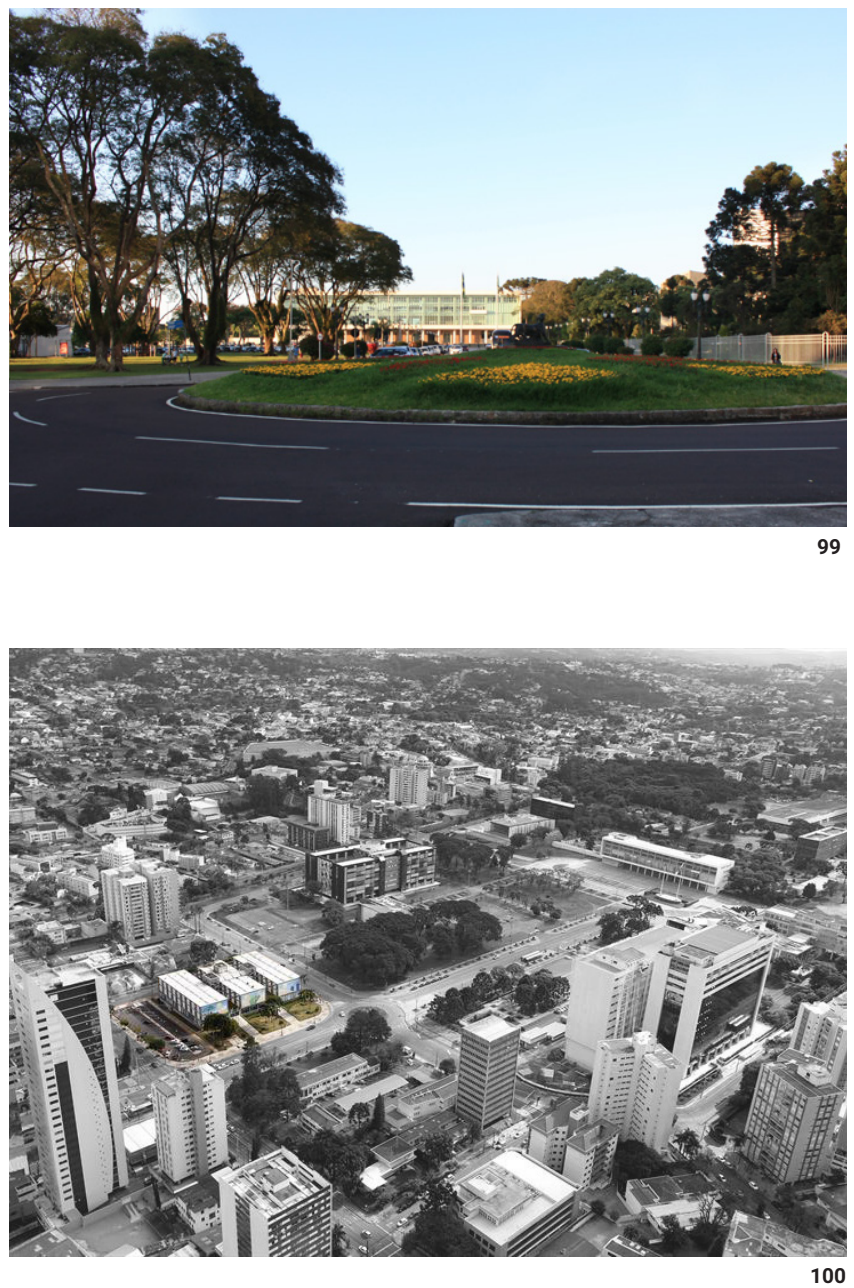
3 Tribunal de contas do Estado

4 Palácio Iguaçu

5 Praça do Rio Iguaçu

6 Secretaria da Assembleia Legislativ

7 .

8 Anexo da Assembleia Legislative

10 Palácio das Araucárias

11 Tribunal do Júri

12 Palácio da Justiça

13 Palácio 29 de Março

14 Rio Belér

— Eixo da Avenida Cândido de Abreu

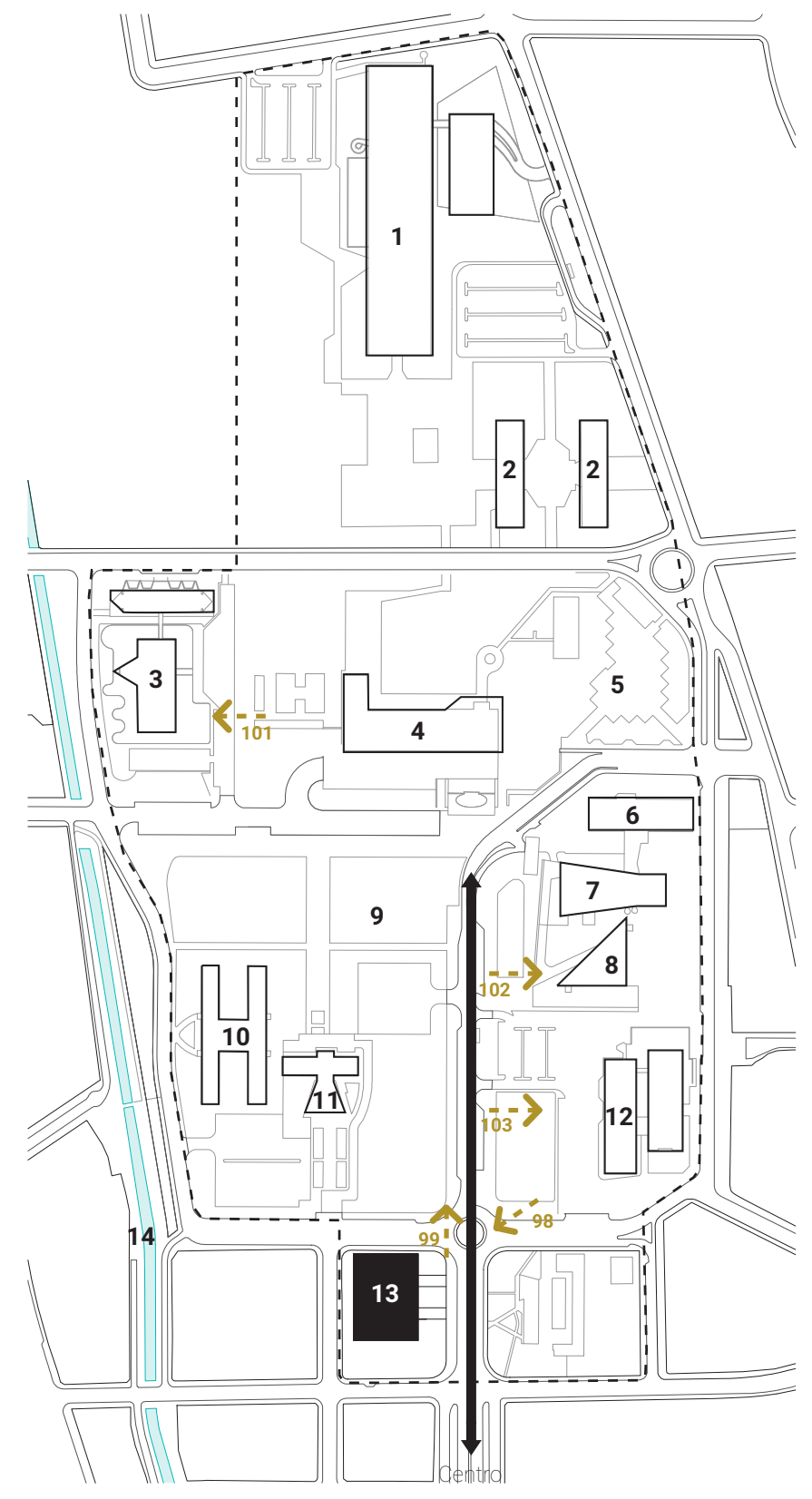

A direita: Situação atual do Centro Cívico do Estado do Paraná e suas edificacões: a relação do eixo da Avenida Cândido de Abreu com o plano e com o Palácio 29 de Março marcado pelo numero 13. Fonte Desenho desenvolvido pelo autor.

Figura 101, 102 e 103 (abaixo): Tribunal de Contas do Estado, Anexo da Assembleia Legislativa e Palácio da Justiça respectivamente. Fonte: Acervo do autor.
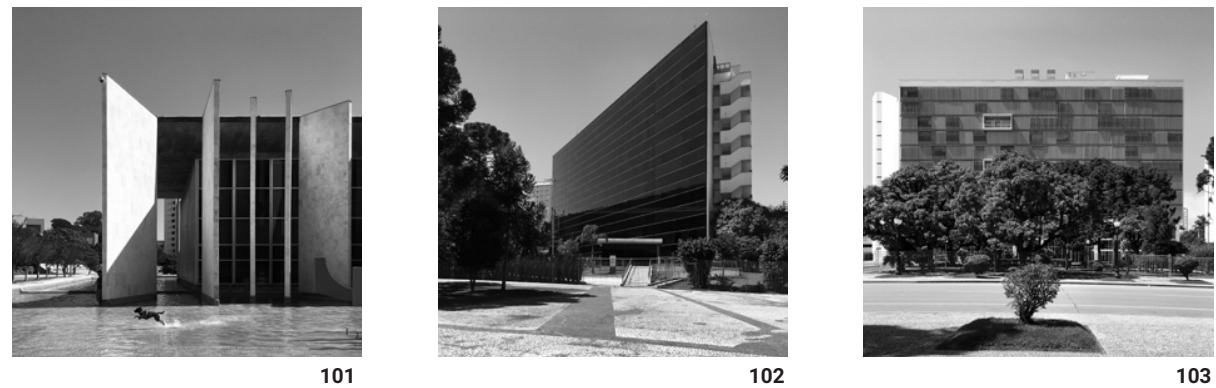


\section{Relação com o terreno}

O edifício foi implantado paralelamente aos passeios públicos e ligeiramente encostado na quina noroeste da quadra, o que possibilitou um afastamento do seu acesso principal ao passeio correspondente ao da Avenida Cândido de Abreu, em frente ao lote. Este distanciamento conecta o prédio à calçada através de largas rampas que, somado à suave elevação do térreo e à largura da avenida, contribui na valorização do aspecto monumental da edificação. Esse modo moderno de concepção pode ter uma leitura fortalecida ao levar-se em conta que durante boa parte das versões do projeto, Meister considerava a utilização de um espelho d'água em frente ao invés de um jardim. O desenho da implantação previa a sul uma torre de dez pavimentos correspondente a uma segunda etapa de projeto, hoje ocupado por um estacionamento.

\section{Percursos externos e acessos}

Chega-se ao Palácio 29 de Março pela Avenida Cândido de Abreu. Durante a aproximação, vêse a amplidão do espaço e a compreensão do todo é rápida. A simetria e axialidade provenientes da edificação fortalecem essa sensação.

Os vazios nos andares superiores, assim como as caixas de escadas ao fundo, funcionam como elementos que assinalam as portas de entrada do edifício. No nível do pedestre esta demarcação também ocorre como guia do percurso através das rampas e jardins. Tanto pelo seu uso mais próximo dos habitantes quanto pelo cuidado do desenho, é digna de observação a gentileza urbana proveniente do projeto e a sua relação com o entorno.

Do outro lado, a simetria acaba sendo suavizada pelo desnível do terreno. O subsolo aflora em muro revestido por pedras e um acesso de veículos para o estacionamento interno rompe a volumetria deste elemento, o que também ocorre na fachada sul.

Todo as vistas comunicam bem o projeto e a primeira percepção que se tem é contemplativa. O afastamento é grande e a leitura facilitada. Diante do prédio, gradualmente passa-se da compreensão visual para a sensorial ao subir pela rampa entre os jardins e araucárias.

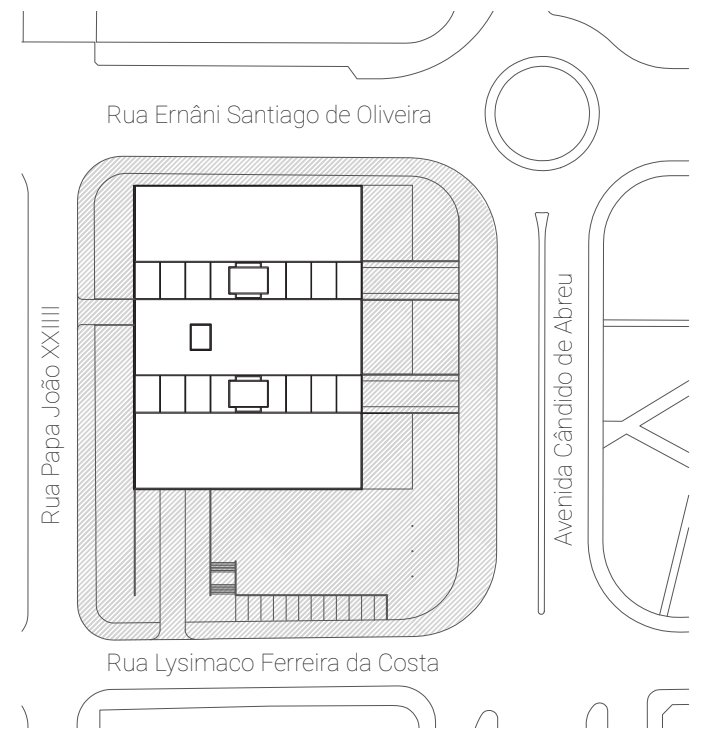

- - - Percursos

\&-- Acesso pedestre

$\leftarrow$ Acesso veículo (subsolo)

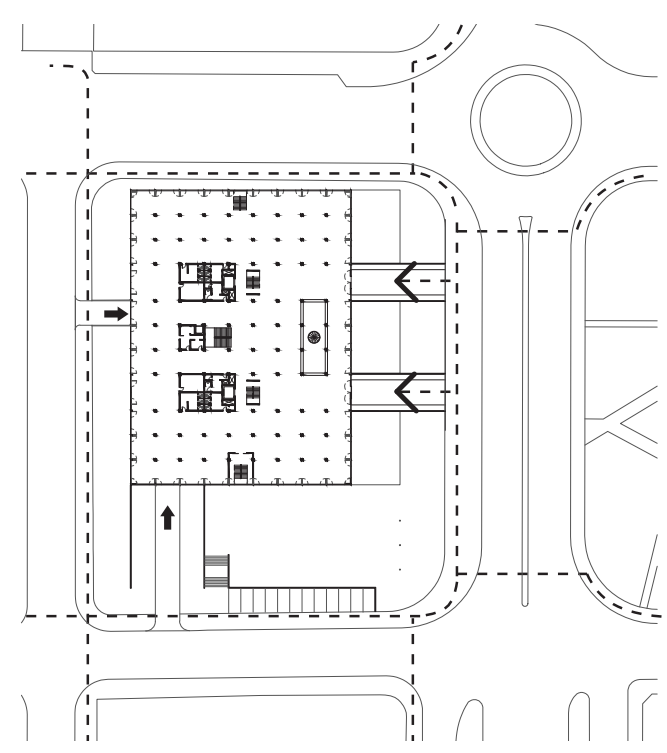


Na página anterior acima: A relação da

edificação com o terreno. Fonte: Desenho

desenvolvido pelo autor

Na página anterior abaixo: Percursos

externos e acessos Fonte: Desenho desen

volvido pelo autor.

Nesta página acima: A marcação dos

acessos na fachada principal. Fonte

Desenho desenvolvido pelo autor

Figs 104, 105, 106, 107, 108 e 109: Per-

cursos externos e aproximações. Fonte

desenho desenvolvido pelo autor

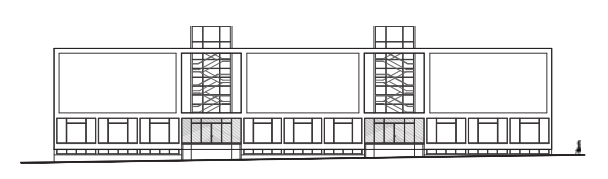

(1)

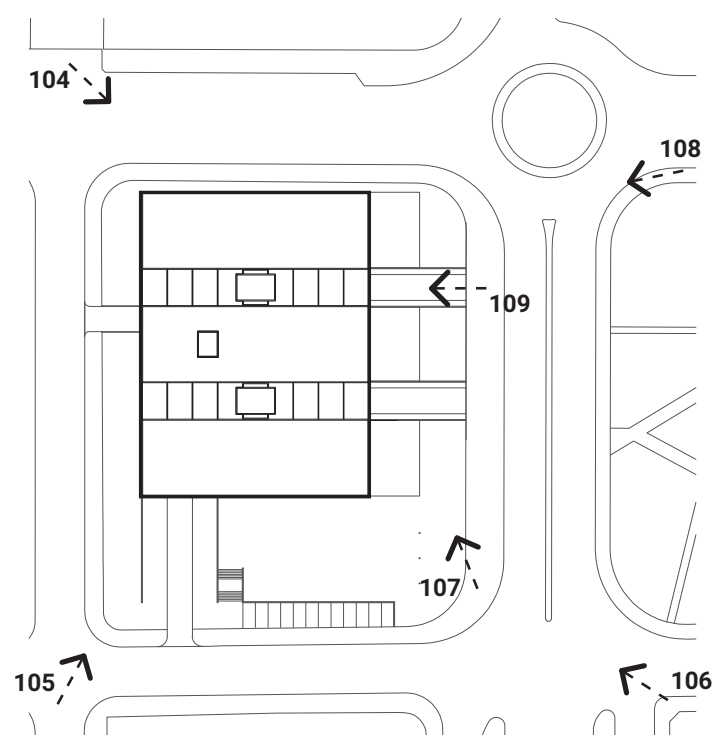

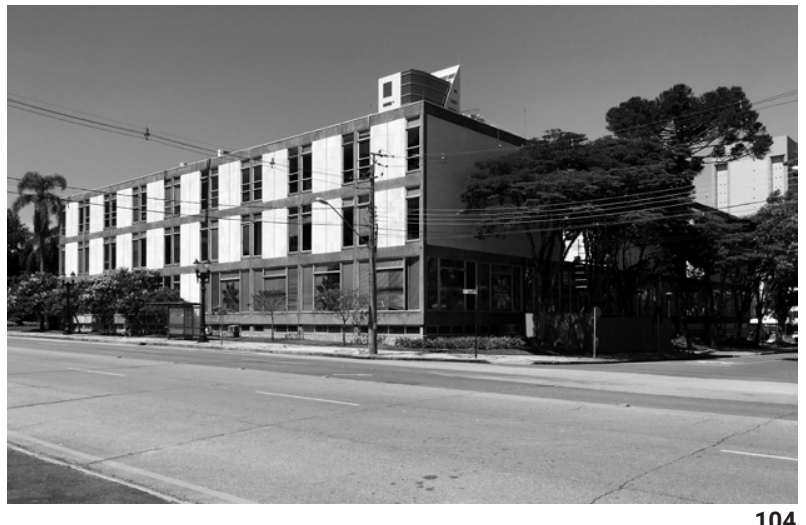
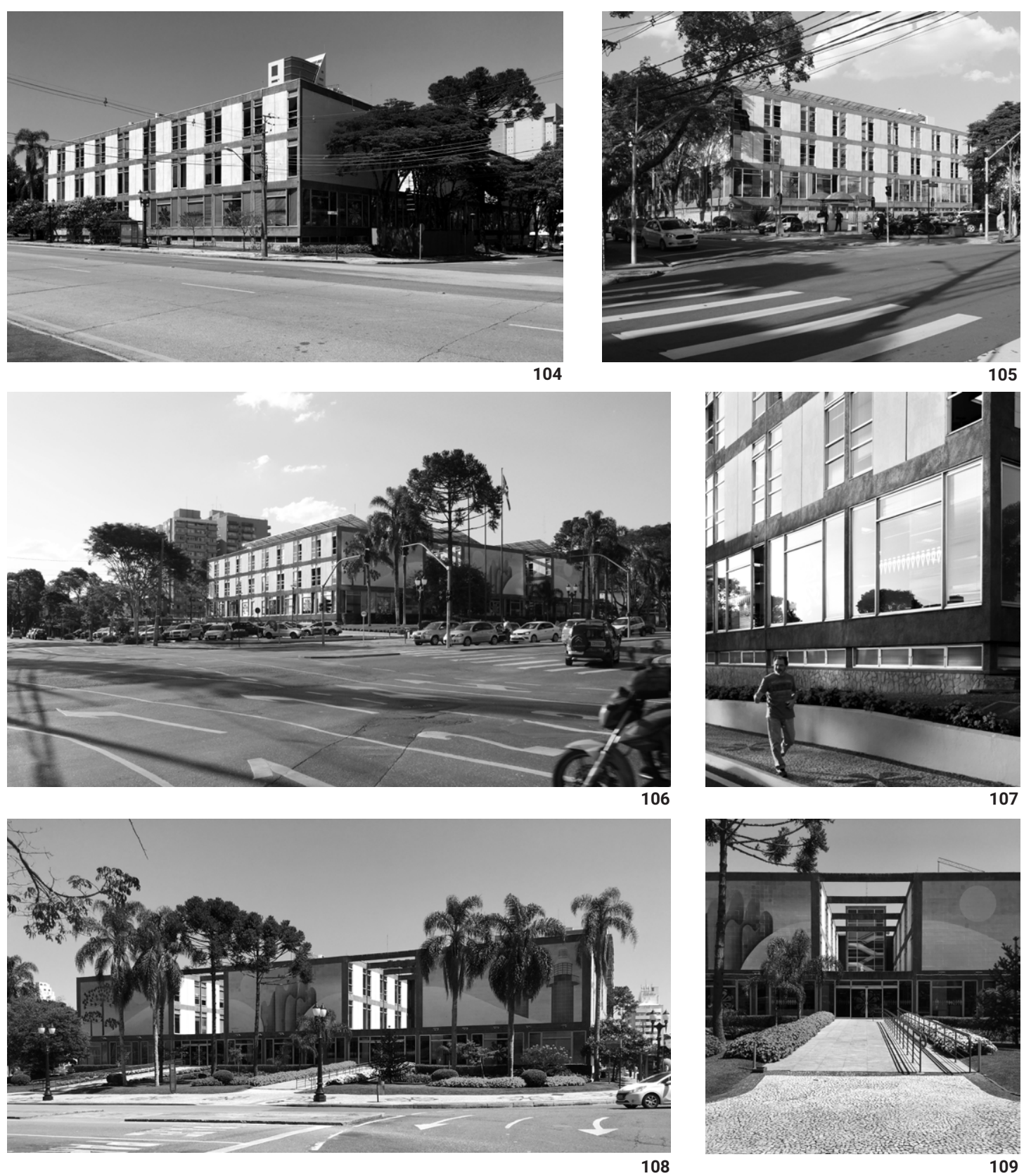


\section{Orientação, insolação e vistas}

Não se pode afırmar que a insolação tenha sido um critério na orientação da edificação. A geração da forma e a disposição dos planos transparentes demonstram ter partido de questões relacionadas à estrutura e à disposição programática. As aberturas nos dois pavimentos de trabalho estão presentes em todas as fachadas norte e sul e foram pensadas em planos menores entre os módulos estruturais, entretanto, sem um anteparo externo de filtro solar. Os jardins dos terraços abrem-se como soluções para que o sol e a luz adentrem estes pavimentos As esquadrias, nesses vazios, são todas de mesma dimensão e estão dispostas de forma equivalente nas fachadas. Os ambientes voltados à sul saem-se prejudicados pela baixa incidência solar e pelo sombreamento da própria edificação. O gabinete do prefeito assim como os salões de eventos, estão localizados no bloco central, ou seja, possuem aberturas apenas para aqueles terraços internos. São os ambientes mais privativos e controlados

No pavimento térreo as visuais externas se abrem em todas as orientações, principalmente na fachada junto à Avenida Cândido de Abreu (figura 110). A porção central é carente de sol e luz tendo em vista que os jardins internos dos terraços não atendem a este nível.

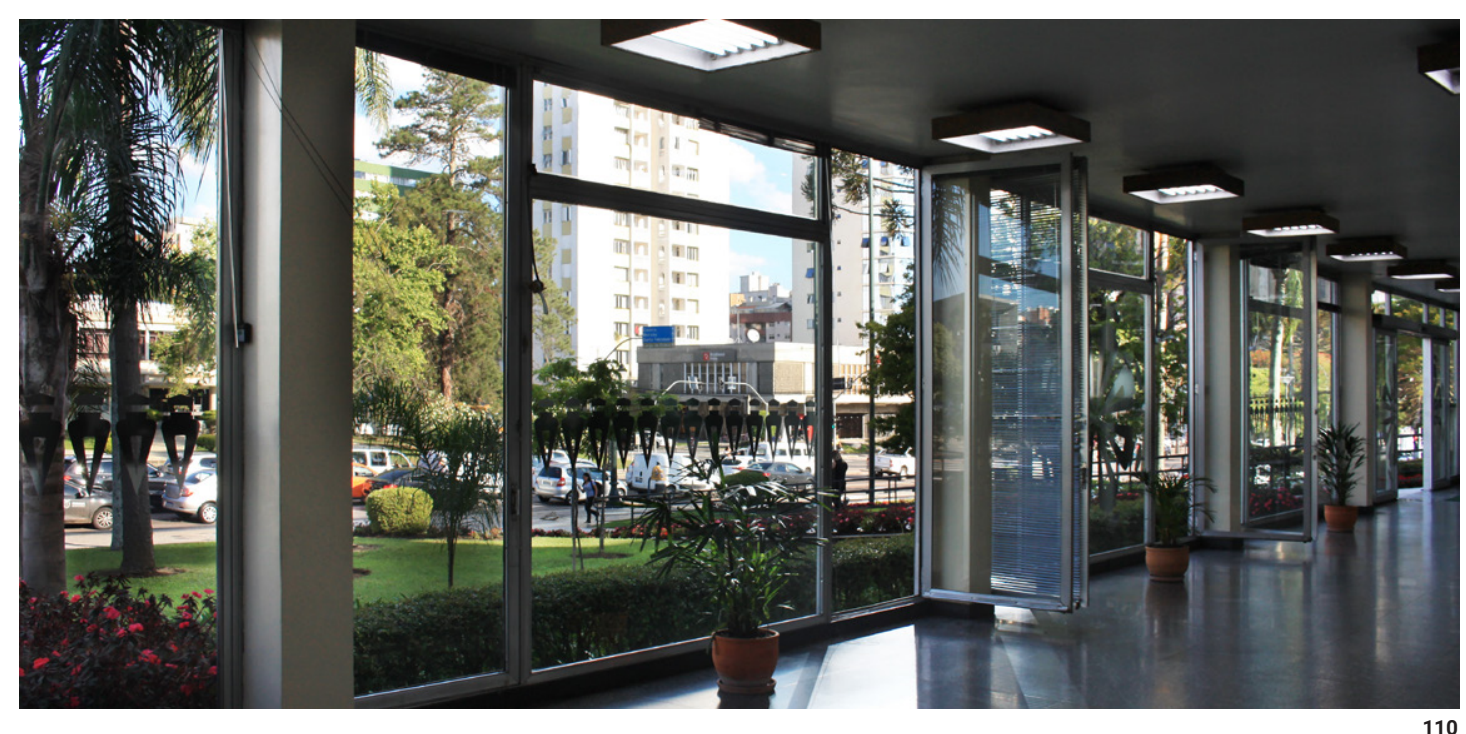

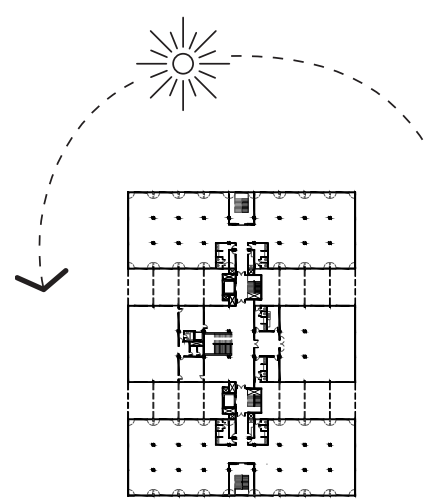

A primeira planta representa a trajetória solar no período de inverno, Fonte: Desenho desenvolvido pelo autor.

A segunda e a terceira planta representam as relacõos visuais noplano horizontat no téreo nos pavimentos superiores, e nos pavimentos superiores, respectivamente. Fonte: Desenho desenvolvido pelo autor.

Figura 110 (abaixo): Visual externa da Avenida Cândido de Abreúa partir do povimento térreo Fonte. térreo. Fonte Acervo do autor

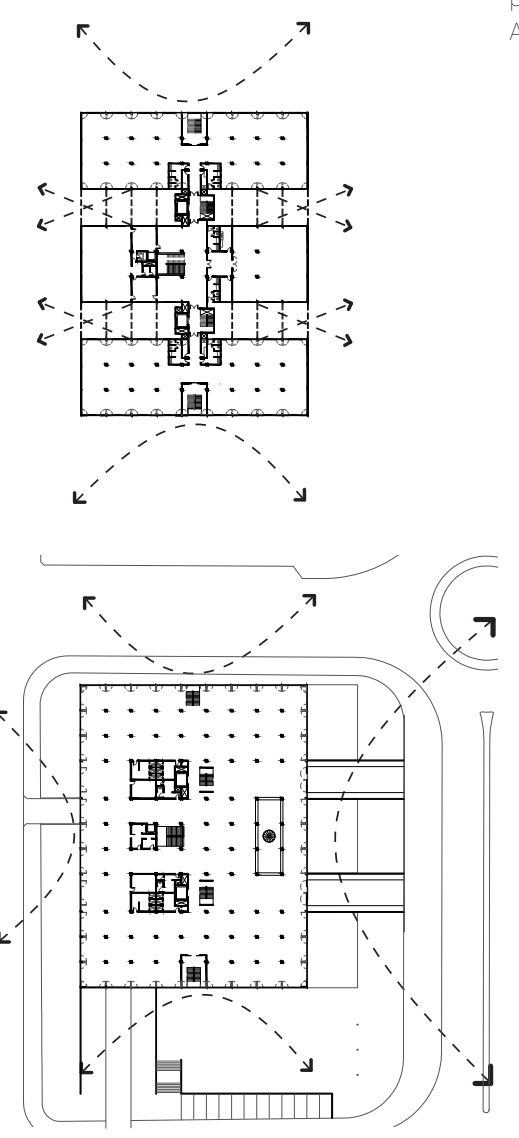



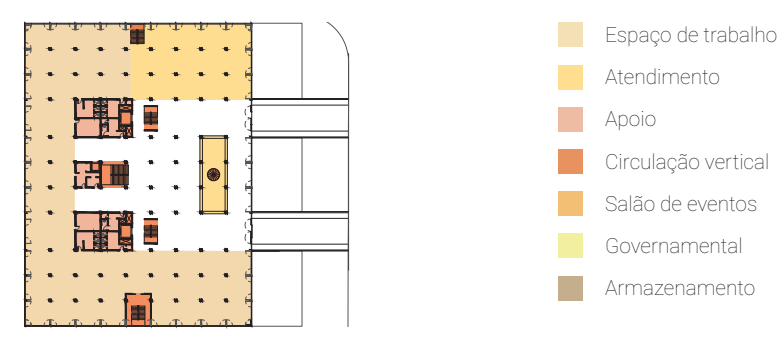

Térreo

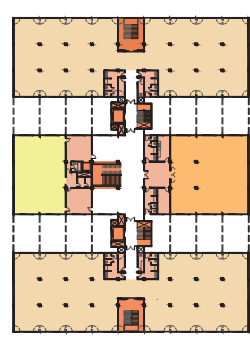

$1^{\circ}$ pavimento

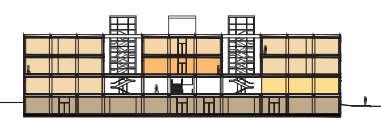

Corte Longitudina

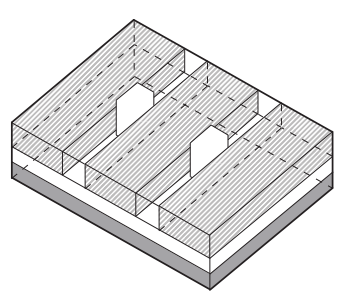

\subsection{FORMA, ESPAÇO E PROGRAMA}

\section{Setorização e programa}

Para o projeto do edifício, Rubens Meister partiu da distribuição de usos por pavimento em decorrência da relação com a população - acesso e funções - e das atividades mais internas ao governo do município. Sendo assim, procurou vincular um térreo livre e aberto ao público, dotado de locais para espera, atendimentos e exposições, enquanto destinou funções administrativas e da esfera governamental para os dois pavimentos superiores. Para o subsolo destinou uso de estacionamento, infraestrutura, almoxarifado e apoio.

Através dos desenhos de plantas e cortes ao lado pode-se perceber que a setorização clara e a disposição dos acessos permitem fácil leitura e orientação ao usuário. No pavimento térreo, localiza-se ao centro da planta um espaço de exposições e balcão de informações, um setor à norte se ocupa do atendimento ao público através dos guichês, sendo os demais espaços utilizados por áreas de trabalho, apoios e circulações verticais. O subsolo é ocupado essencialmente por serviços de apoio às atividades da prefeitura. No primeiro pavimento, as duas barras extremas também setorizam os trabalhos, enquanto a barra central abriga o setor governamental (gabinete do prefeito) no lado oeste, em posição central e de destaque, e um salão de eventos no lado leste. No segundo pavimento o todo é replicado, sendo que a barra central, nesse caso, também abriga as áreas de trabalho dos departamentos. Essa distribuição dos usos por pavimentos configura uma organização estratificada do programa por níveis bem como uma divisão vertical de acesso público e privado (diagrama à esquerda). 

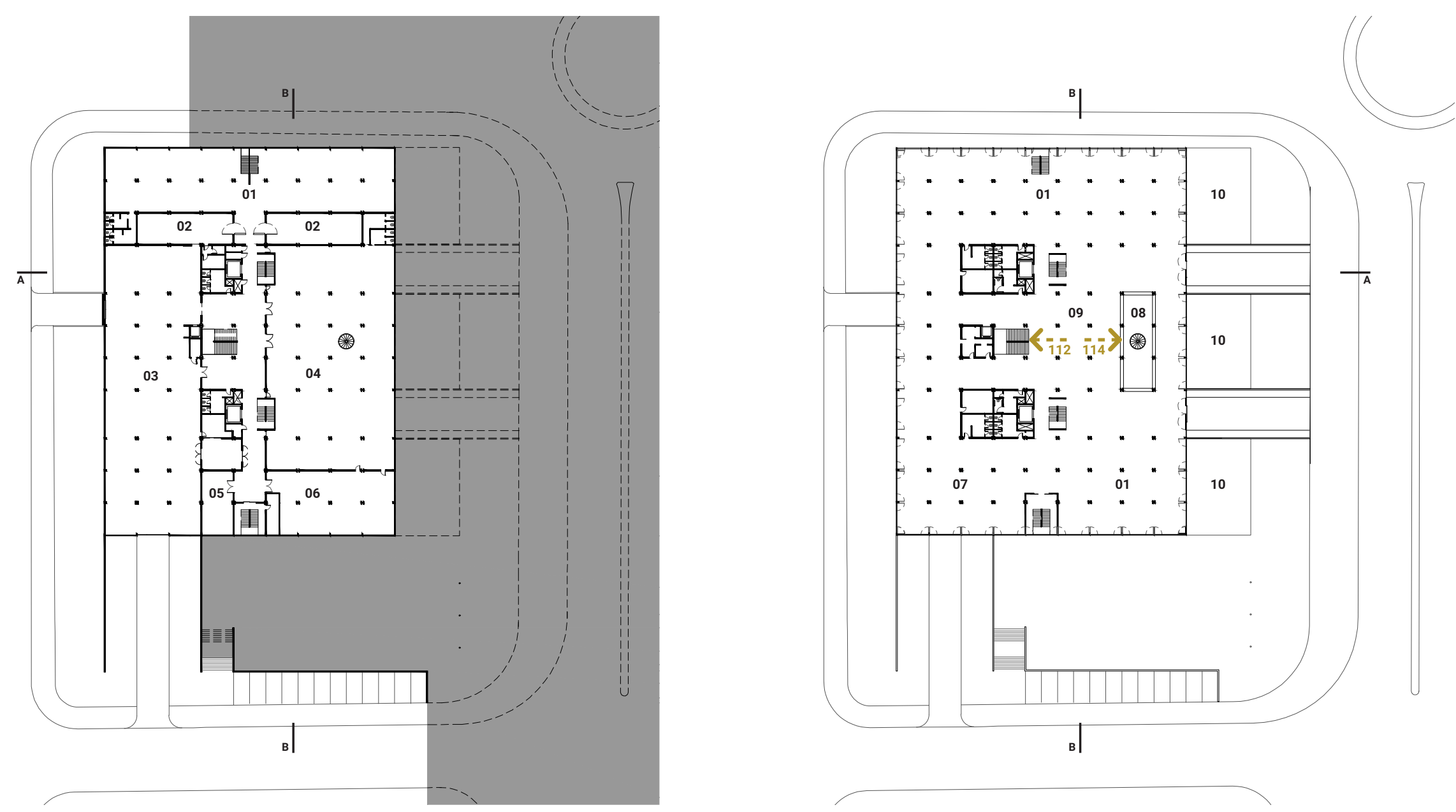


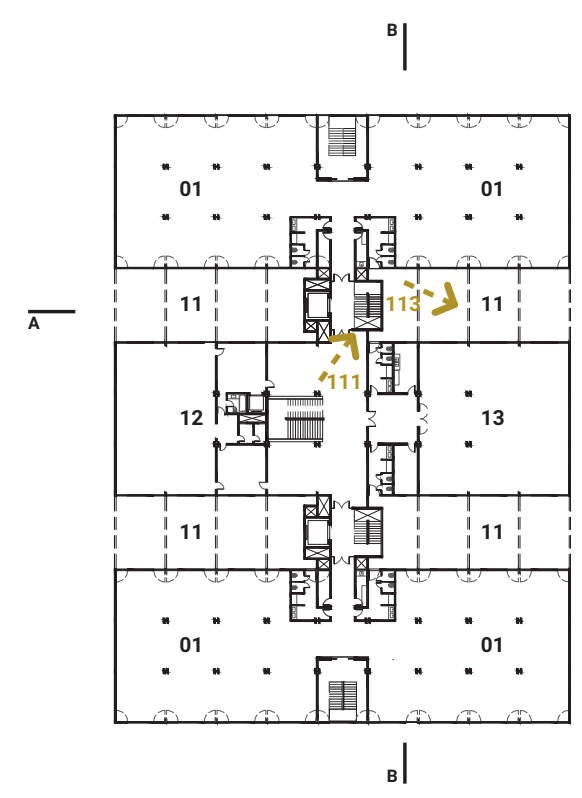

$1^{\circ}$ pavimento

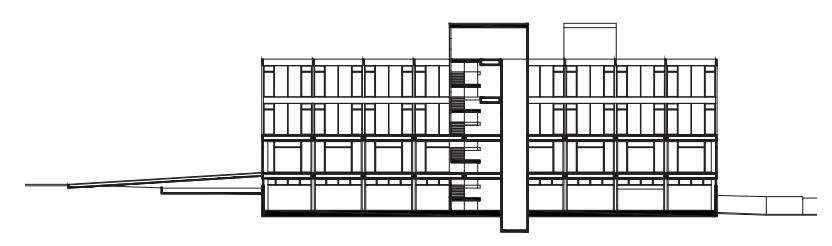

Corte AA

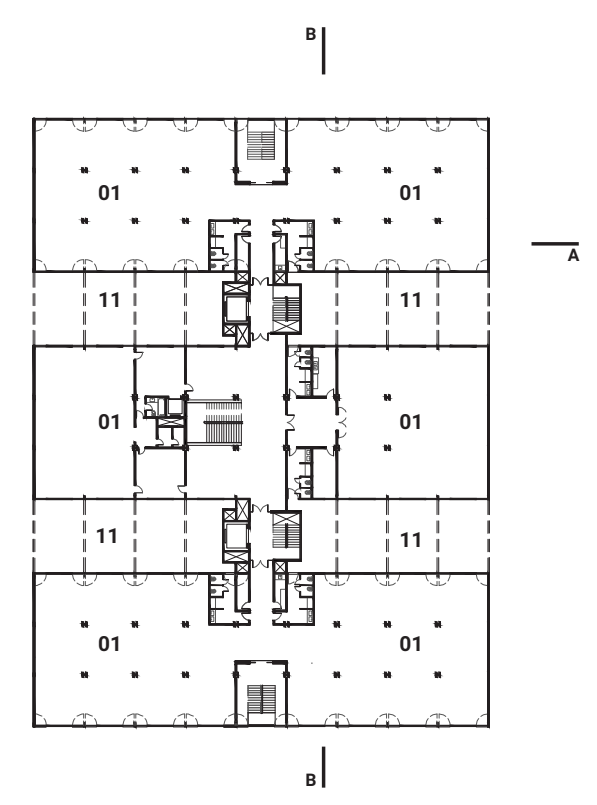

$2^{\circ}$ pavimento

(1)

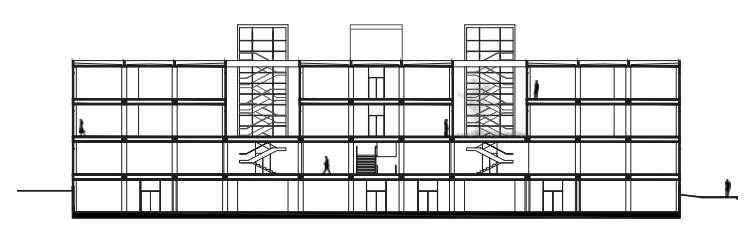

Corte BB

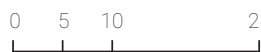

01 Departamentos

02 Caixa-forte

03 Estacionamento

04 Arquivo

05 Almoxarifado

06 Manutençăo

$\begin{array}{ll}07 & \text { Divida ativa } \\ 08 & \text { Informacōes }\end{array}$

09 Exposiçōes

11 Terraço jardim 

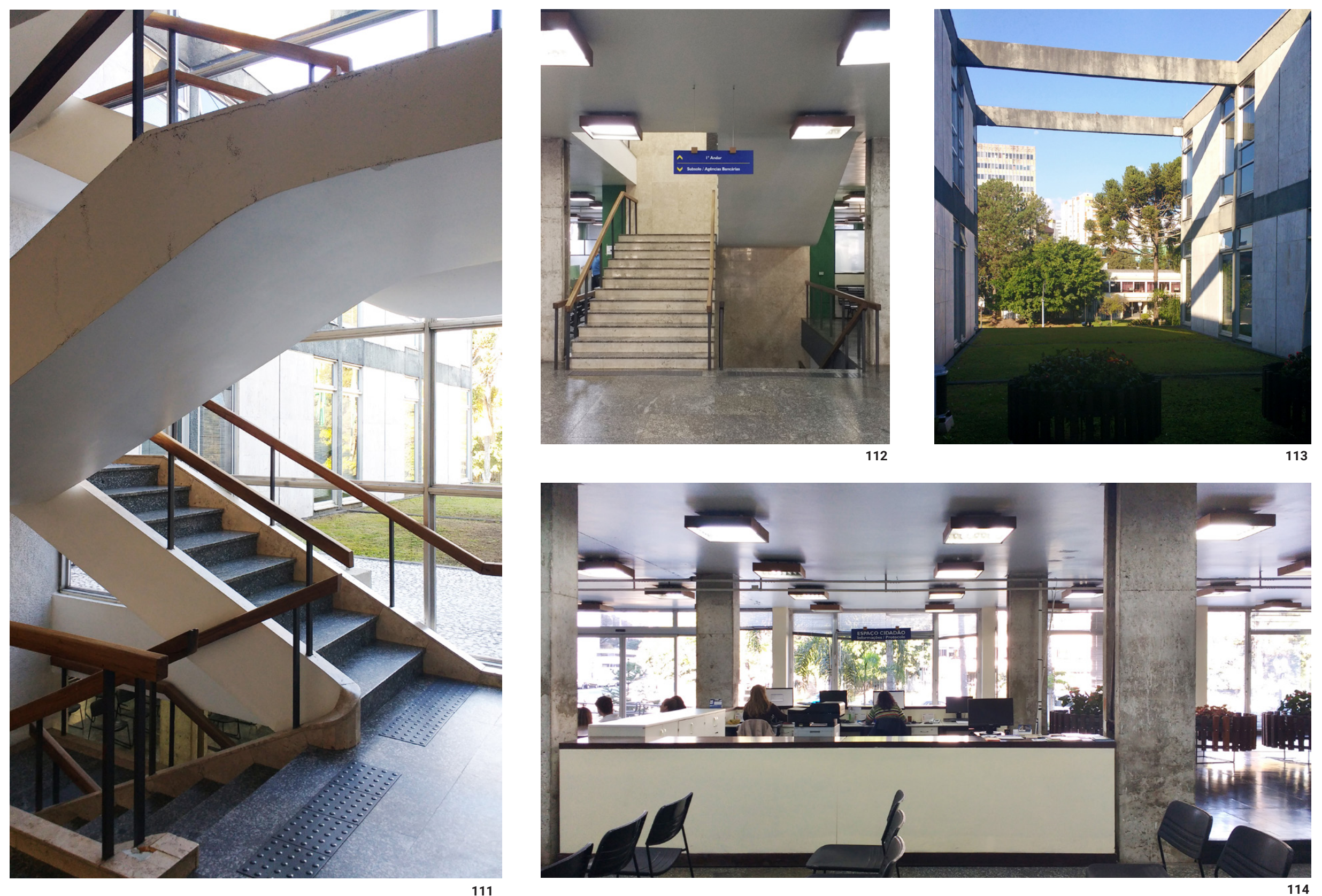


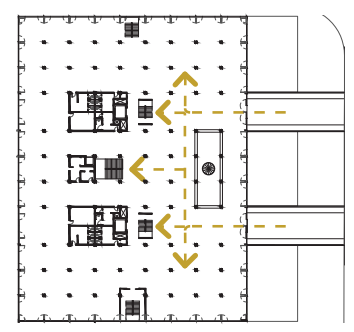

Térreo

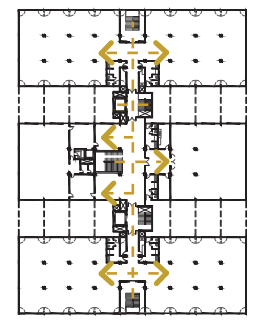

$1^{\circ}$ pavimento

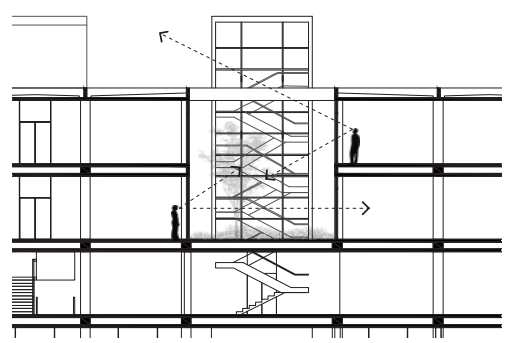

\section{Circulações e percursos internos}

As circulações internas, formalizadas por corredores em pontos específicos, são claras e adequadas à ortogonalidade, simetria e organização da planta.

O percurso em busca do atendimento ao público é rápido e eficaz por estar prontamente relacionado aos setores no pavimento térreo. Os funcionários, que possuem sua base de trabalho no subsolo ou nos pavimentos superiores, dirigem-se às escadas e elevadores alinhados com os acessos e distribuídos de forma bastante funcional entre os planos de trabalho. A escadaria central apresenta uma forma clássica ao centro do saguão e em frente à área de exposição. A partir dela acessa-se as circulações que levam aos departamentos do $2^{\circ}$ pavimento e ao salão de eventos e gabinete do prefeito no $1^{\circ}$ pavimento. Este último possui também acesso privativo através de elevador desde o estacionamento no subsolo.

As escadas opostas norte e sul realizam uma distribuição restrita às atividades do corpo interno da Prefeitura de Curitiba. De uma ponta a outra, principalmente nos dois pavimentos superiores, pode-se observar uma coluna central que transmite eficiência e equivalência na distribuição dos setores (plantas ao lado). Da parte interna e central do balcão de informações, uma escada circular tem acesso direto ao almoxarifado do edifício

\section{Relação entre espaços internos e externos}

As transições entre as espacialidades internas e externas são maiores no pavimento térreo. As ligações visuais partem das áreas de atendimento, departamentos e espera e alcançam, em primeiro plano, um jardim entre a edifıcação e o passeio e por fım, o cenário da cidade. A continuidade é reforçada através de planos translúcidos que vão do piso ao teto. Em fragmentos menores e encaixadas ao módulo estrutural, as esquadrias nos pavimentos superiores também seguem a lógica de quadros ininterruptos no plano vertical. Essa relação mais sutil, repetidamente interrompida pelas vedações opacas em alvenaria, leva maior privacidade às atividades destes pavimentos ao contrário do maior uso público do térreo. 


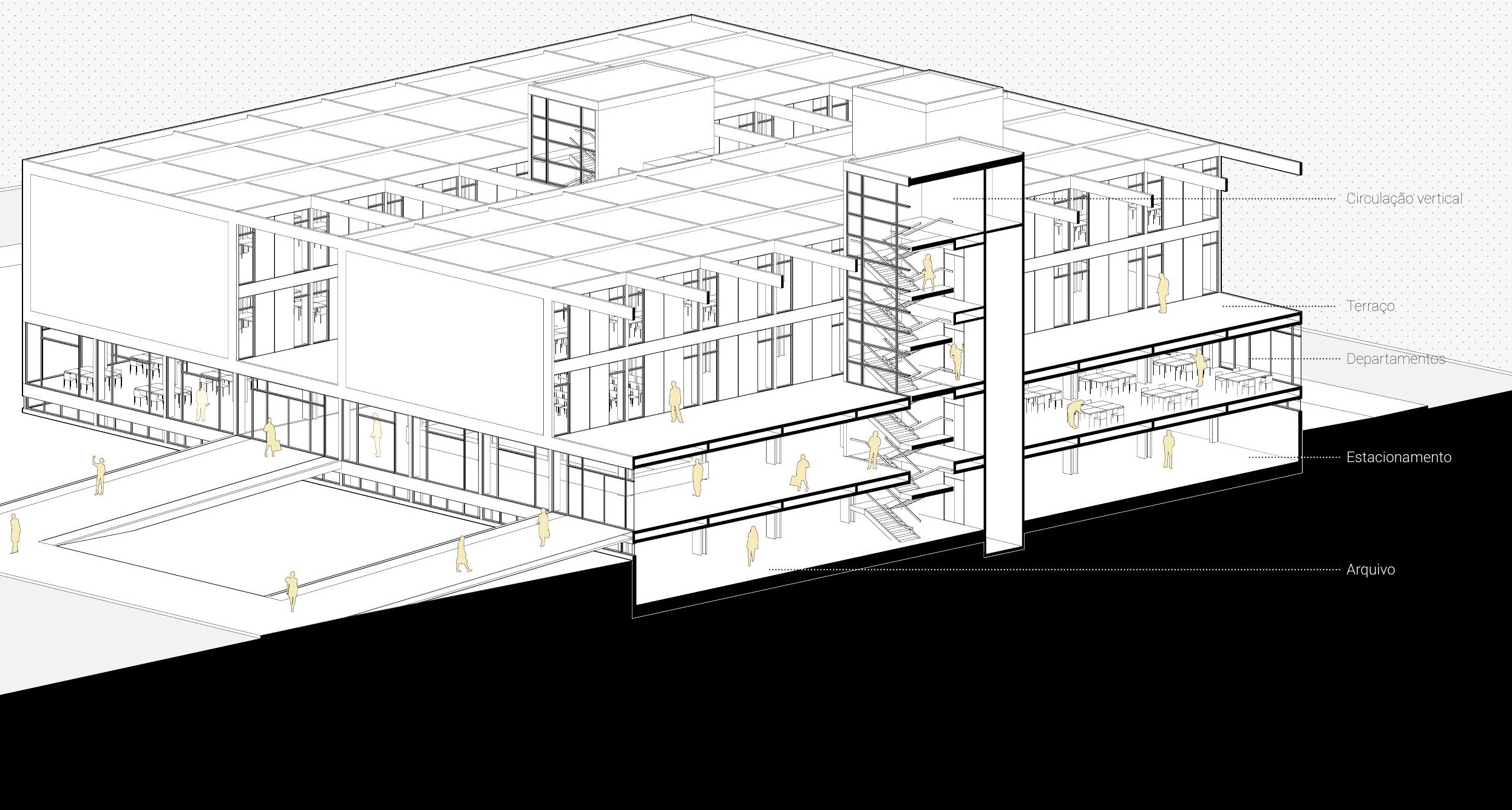


A relação destes espaços através das porções translúcidas é explícita e não possui elementos intermediários de proteção solar como brises ou beirais. Cadenciados nas estações de trabalho, os planos de vidro tornam-se novamente inteiriços - como no térreo - nas fachadas das duas escadas voltadas aos terraços.

\section{Iluminação natural}

Ao contrário da orientação solar, pode-se afirmar que a iluminação natural tenha sido critério adotado por Rubens Meister na concepção das espacialidades internas. Os padrões adotados nas relações entre elevações, composições dos planos opacos translúcidos e atividade interna denotam que esta abordagem não foi tratada isoladamente no projeto.

No plano horizontal é notada a equivalência na entrada de luz pela fachada, porém de forma distinta entre os pavimentos. O pavimento térreo, maior e com espaços mais abertos, é cercado pela incidência de luz externa. A porção central, no entanto, é carente desta iluminação tendo em vista que os jardins internos dos terraços não atendem este nível. De forma insuficiente, o subsolo conta com aberturas perimetrais menores e com maior segmentação interna dos ambientes. Os pavimentos superiores possuem uma entrada da luz natural mais equilibrada e melhor distribuída nos espaços de trabalho. A disposição das barras e terraços cumprem um papel fundamental nesse aspecto mesmo possuindo esquadrias de dimensões reduzidas.

Os momentos em que se observam uma relação da iluminação no plano vertical ocorrem nas faixas correspondente aos terraços. O contínuo plano translúcido das duas escadas voltadas à área aberta e "controlada" pela continuação das vigas estruturais da cobertura, obtém na luz um importante elemento nas relações dos espaços entre os dois pavimentos superiores. 


\subsection{MODULAÇÃO, ESTRUTURA E EXPRESSÃO}

\section{Organização espacial}

A diretriz adotada por Rubens Meister neste projeto é a sua rigorosa regularidade a partir da malha ortogonal. A medida identificada e que dá o arranque à edificação é a de 16 centímetros: notado nos degraus da escada (16 centímetros de espelho por 32 centímetros de piso) e no tijolo das alvenarias e pilares da fachada. A derivação dessa dimensão se estende pelo edifício em sua totalidade. A altura do sistema laje + piso é de 64 centímetros, ou seja, o desenho da estrutura no plano vertical corresponde a um terço do desenho das vigas no plano horizontal. A largura das esquadrias é de 112 centímetros, a travessa da bandeira possui 64 centímetros de altura e o entrepiso 384 centímetros (3,84 metros)

A malha estrutural proposta para abrigar o programa (essencialmente em planta livre) e a área necessária contém 9 módulos de 5,12 metros na largura do edifício e no comprimento três sequências de 3 módulos de 5,12 metros intercalados de um módulo de 7,68 metros em meio a eles, ocupado pelos terraços e núcleos de circulação. Esta mudança no módulo, corresponde ao primeiro e segundo terço na proporção da edificação, separando os dois pavimentos superiores em três barras transversais de tamanhos idênticos, equidistantes e, ao mesmo tempo, criando jardins entre as mesmas, alinhados aos núcleos de circulações verticais. A largura de cada barra corresponde a dois terços do distanciamento entre elas sendo que os dois acessos principais do térreo e suas respectivas rampas encontram-se alinhados a este distanciamento e entre a modulação de 7,68 metros.

Na porção do bloco central referente aos salões de eventos, Meister optou por retirar os dois pilares centrais correspondentes ao segundo e o penúltimo eixo estrutural na largura da edificação, conferindo uma espacialidade mais ampla nos gabinetes e uma flexibilidade no uso do salão.

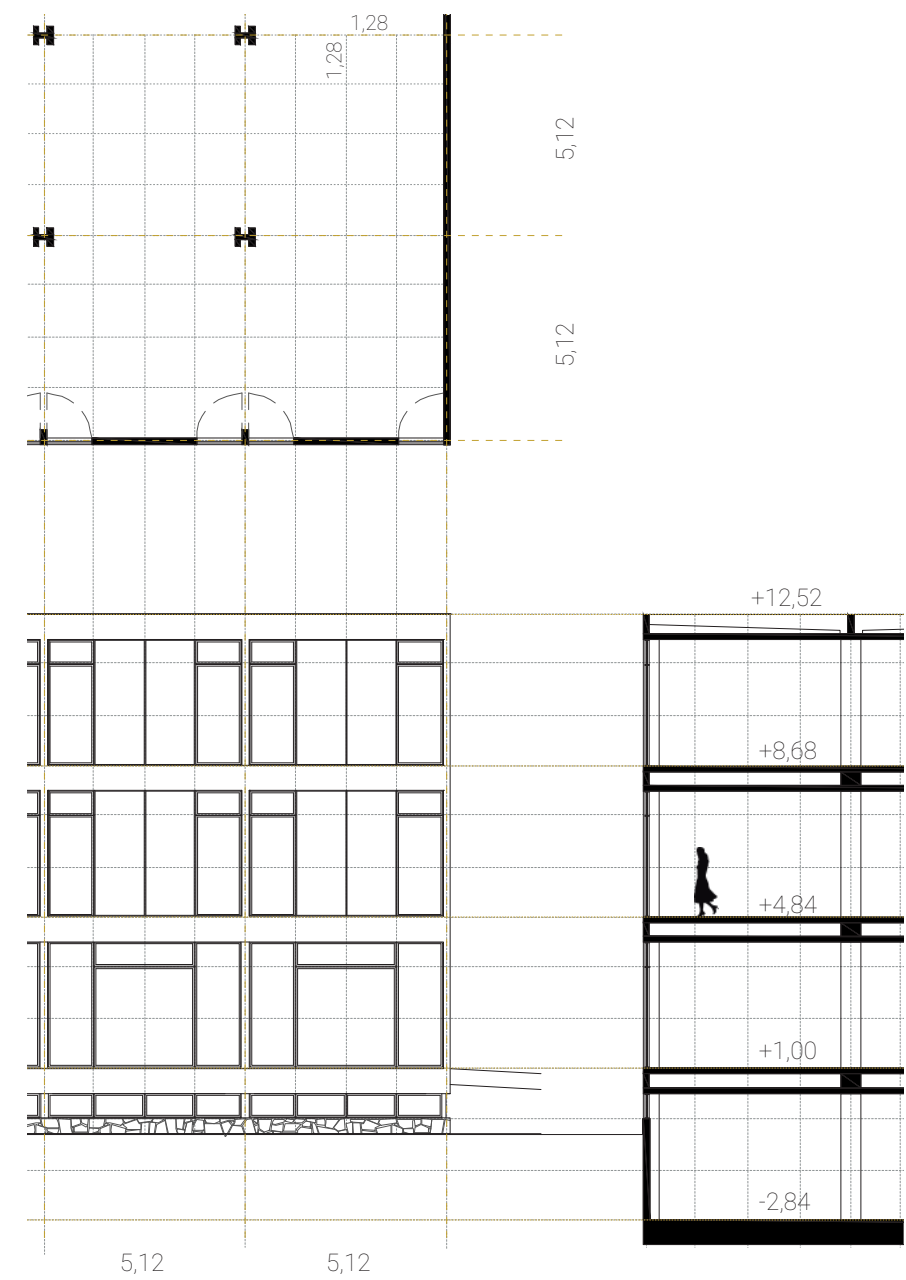

Acima: o emprego do módulo e o seu desdobramento externo. Fonte: desenho desenvolvido pelo autor 
Acima: o emprego do módulo estrutural Fonte: Desenho desenvolvido pelo autor

Figura 115 (abaixo): A continuação das vigas estruturais entre os blocos e sobre o terraço. Fonte: Acervo do autor.
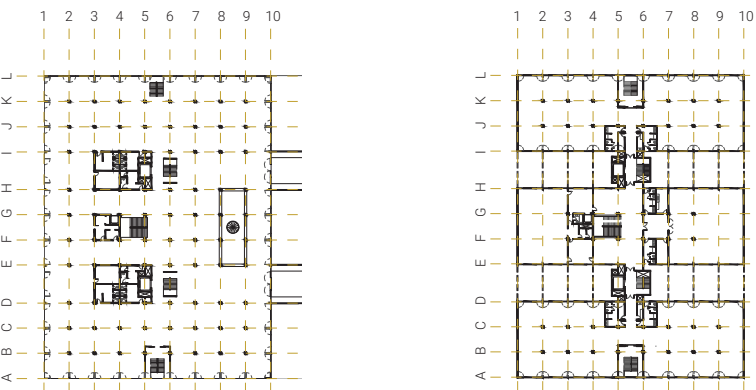

Térreo

$1^{\circ}$ pavimento

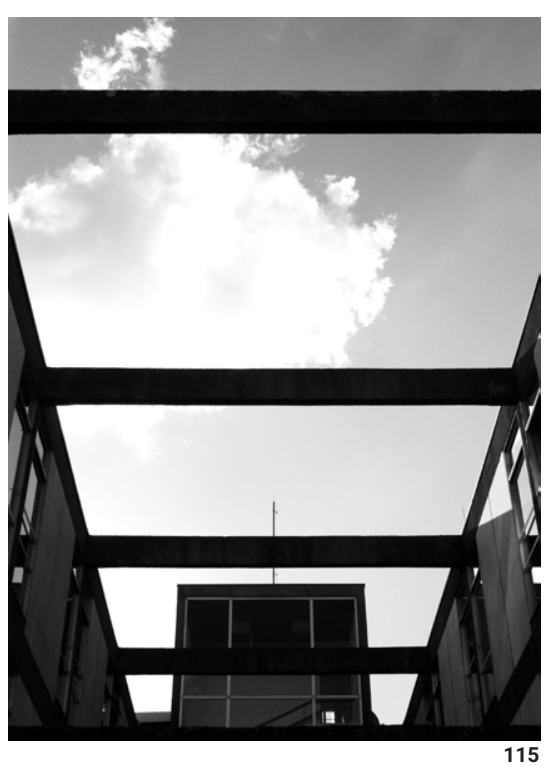

\section{Composição geométrica}

Para as relações visuais internas à edificação, Rubens Meister optou por utilizar os mesmos 3,20 metros de pé-direito para todos os pavimentos. A medida, utilizada por Mies van der Rohe em suas residências, possui metade do valor corresponde a altura média da visão do observador, possibilitando-o compreender o espaço a partir do ponto central e simétrico da perspectiva.

"Uma outra estratégia, complementar, estará ligada à percepção do espaço e a recursos puramente compositivos. Como já observado por Robin Evans, Mies van der Rohe substitui a simetria vertical clássica por uma outra, horizontal, que induz o olhar e seu movimento a um novo plano de simetria. Para isso, excepcionalmente, fixará a altura do pé-direito em uma dimensão próxima a 3,20 metros, situando o ponto

de vista em um plano simétrico em relação ao piso e ao teto, num elementar, mas sutilismo, mecanismo compositivo que determinará

uma completa reorganização visual e espacial."

(ÁBALOS, 2003, p.31)

As três barras que funcionam visualmente como edificações independentes, são incorporadas ao todo através da continuação do desenho da estrutura (figura 115). A fim de amarrá-las não apenas estruturalmente, mas também visualmente, Meister conferiu unidade e forma clara e bem definida ao projeto (figura 117). O resultado consiste em um prisma de 46,24 metros de largura, 61,74 metros de comprimento e 13,20 metros de altura em sua fachada principal. Sem comprometer a pureza da forma, os núcleos de circulação, que contém as escadas e elevadores principais, projetam-se verticalmente e soam como corpos soltos nos pavimentos superiores, mas são incorporados definitivamente ao cerne da edificação no pavimento térreo.

Em uma leitura gráfica que busca separar as diferentes peças de composição, outras 

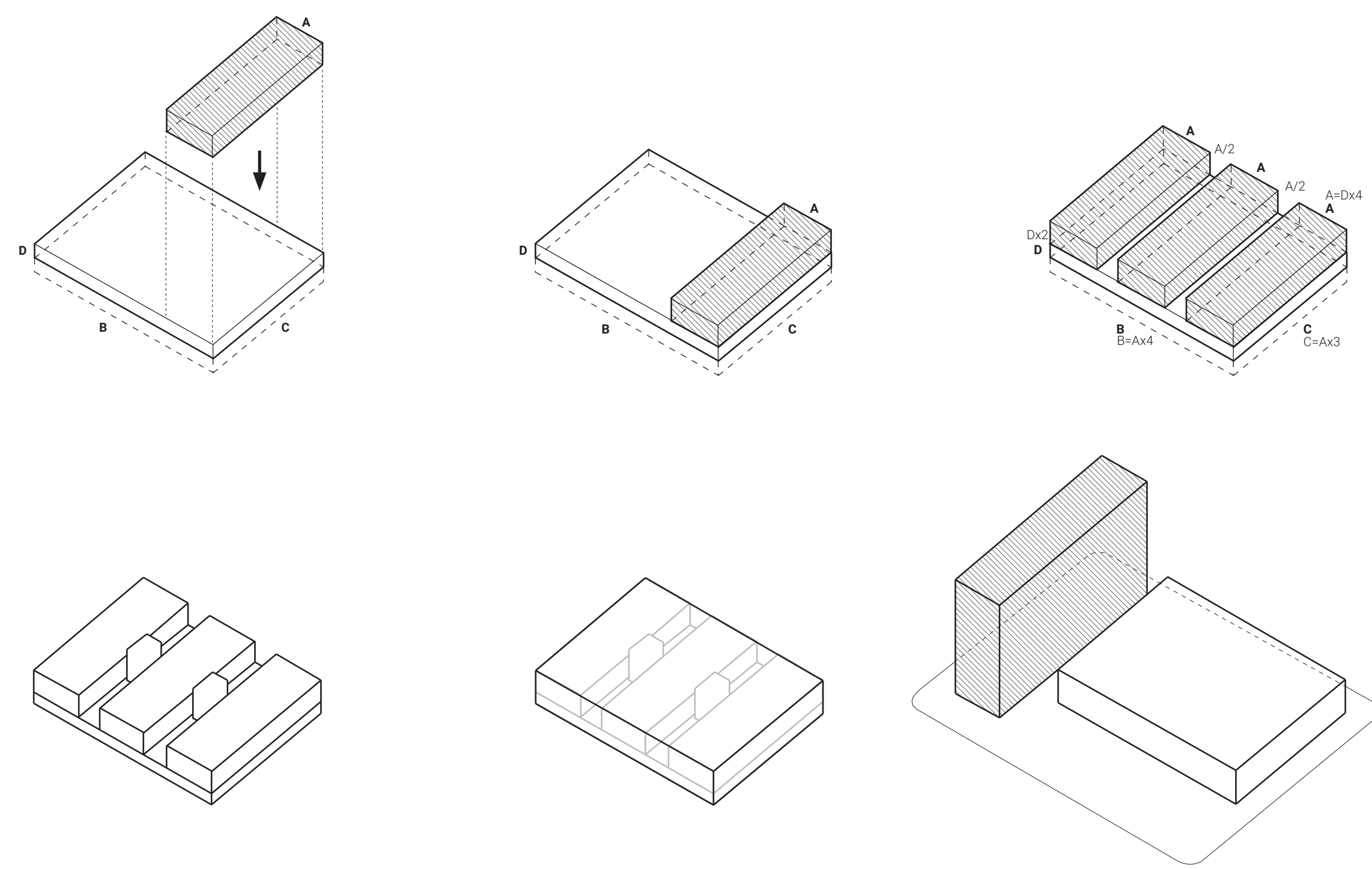


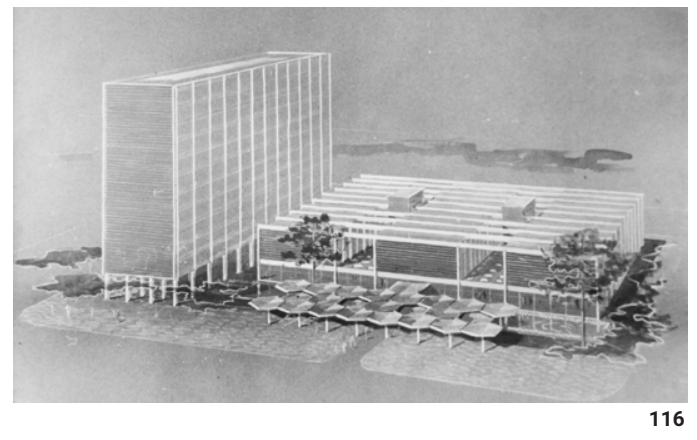

Na página anterior: Diagramas mostrando a relação dos diferentes elementos de composição do todo. Fonte: Desenho desenvolvido pelo auto

Figura 116 (nesta página acima): Desenho nardo Palácio 29 de har do Palacio 20 de Marco que contava com a torre anexa e uma marquise en módulos hexagonais. Fonte: Acervo Rubens Meister

Figura 117 (nesta página à direita): As três barras inseridas em meio ao "esqueleto" estrutural configurados en um volume único Foto da década de 1970 Fonte Acervo Rubens Meister. relações podem ser observadas (diagramas superiores na página anterior). As proporções 2x1 das barras, aqui representado por A e A/2, relacionam-se ao fator 4:3 de proporção da planta, onde o comprimento $B=A \times 4$ e a largura $C=A \times 3$. Em altura, o entrepiso $D=A / 4$ mantém o padrão no plano vertical, conferindo o mesmo critério ao todo.

Assumindo (a partir dos diagramas inferiores na página anterior) como estaria disposto o complexo, caso a torre anexa fosse executada, pode-se perceber em primeiro lugar que a localização da edificação construída mais próxima à quina da quadra faz mais sentido ao se considerar esta futura expansão. E em segundo lugar, a composição de volumetrias pretendida por Meister. O volume anexo, mais alto, distancia-se do mesmo espaçamento modular das demais barras do andar superior, 7,68 metros, e possui seus módulos internos alinhados a edificação existente seguindo a mesma configuração, 5,12 x 5,12 metros. Esta versão foi desenhada pelo engenheiro-arquiteto em versão preliminar do projeto (figura 116).

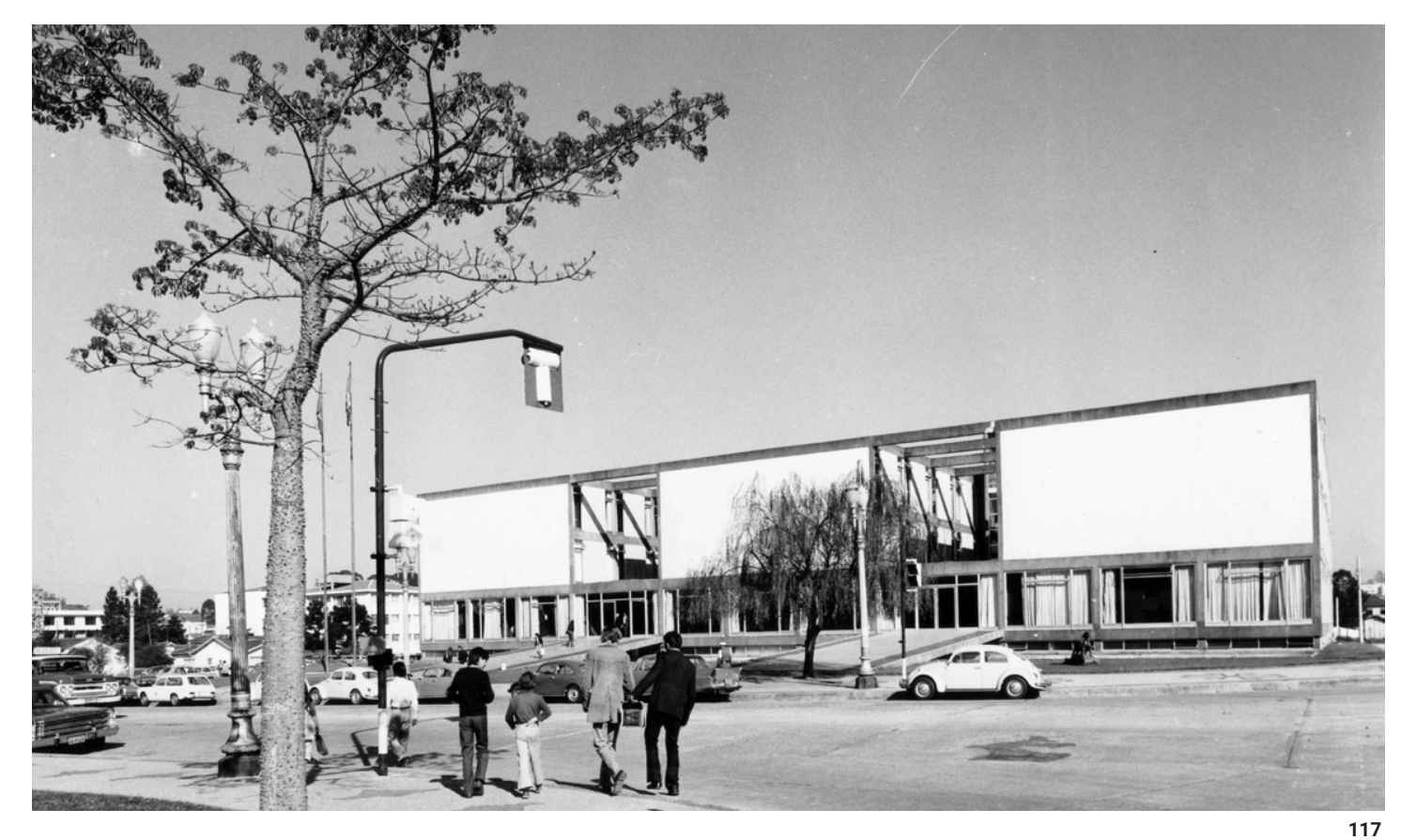



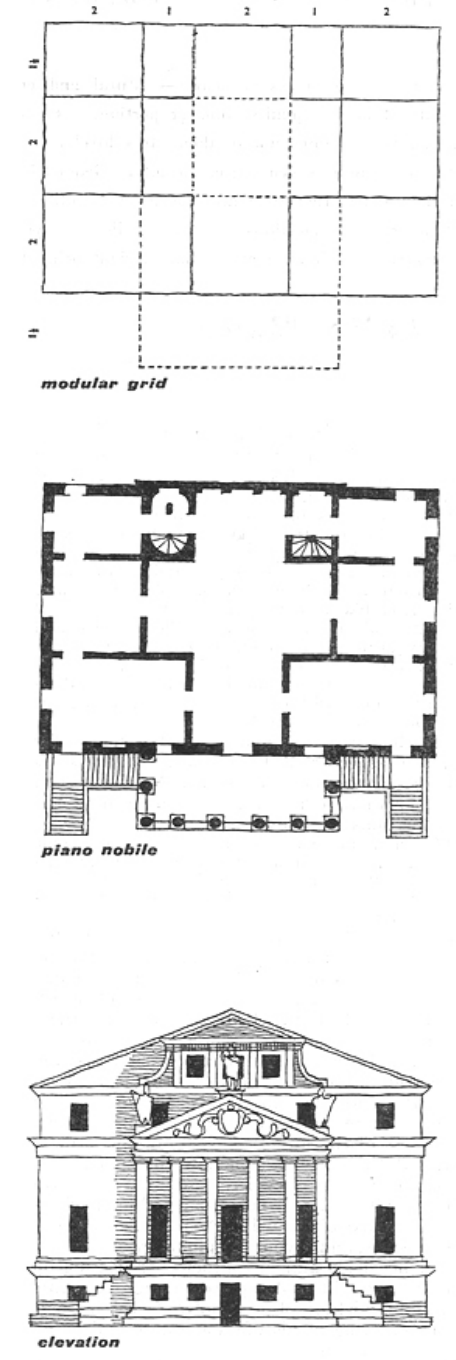
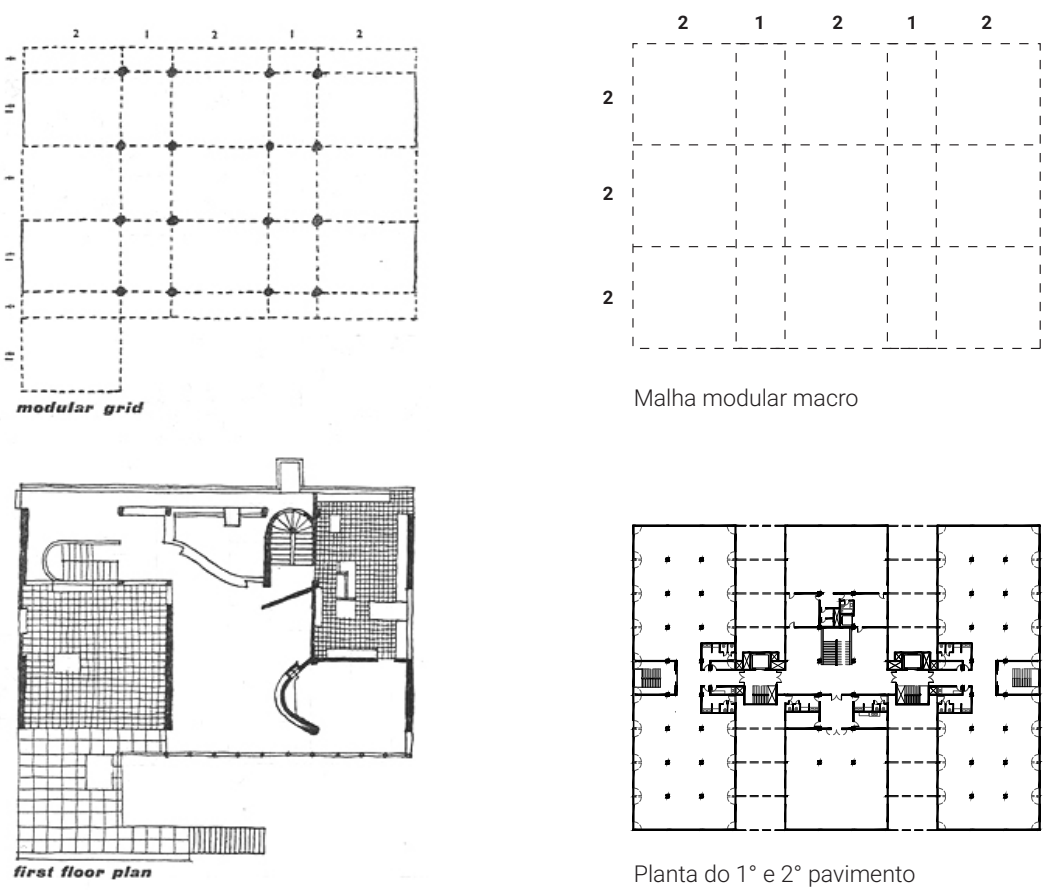

Planta do $1^{\circ} \mathrm{e} 2^{\circ}$ pavimento
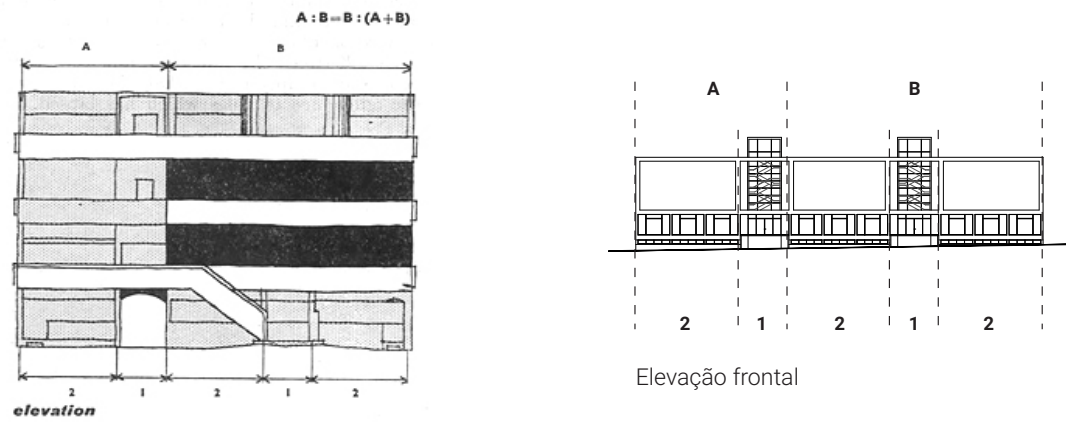

Fiqura 118: Leituras de Colin Rowe comparando a Casa Foscari de Palladio e a Casa Stein de Le Corbusier somado de um comparativo com o Palácio 29 de Março seguindo os mesmos critérios. Fonte: ROWE, Colin The Mathematics of the Ideal Villa and Other Essays; Massachusetts Institute of Technology Cambridge/London, 1976 p 9-33 Desenhos do Palácio 29 
Figura 119, 120 e 121 (nesta página): A caixilharia, estrutura e vedação na expressão plástica da fachada do Palácio 29 de Março, Edifício Lydio Bettega (1962) e Sede da Celepar (1964) respectivamente Fonte: Acervo do autor.

Figura 122 (na próxima página): A relação vertical entre os planos das esquadrias vedecão e estrutura Fonte: Acervo do autor
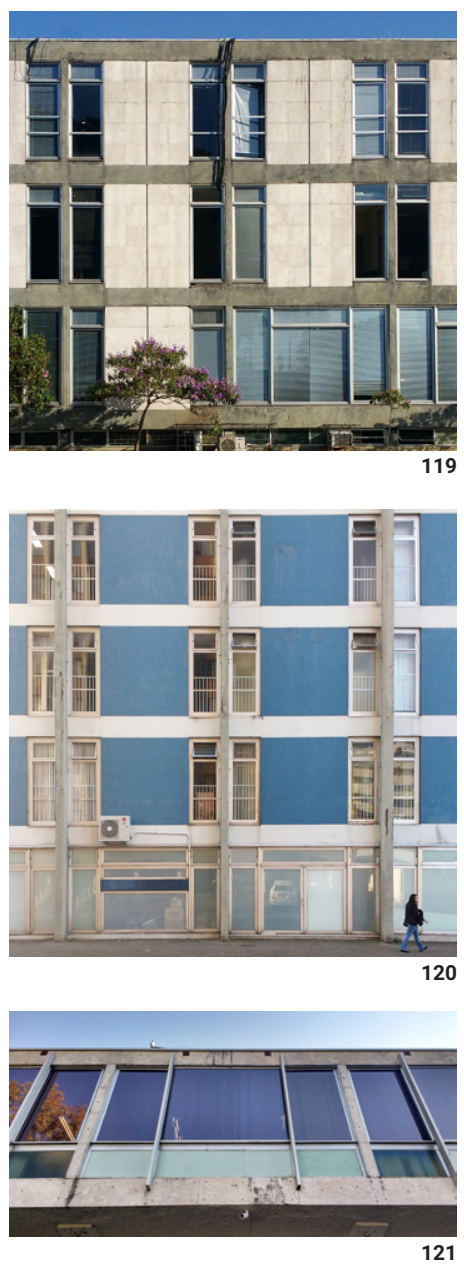

As relações dimensionais utilizadas no edifício estão diretamente vinculadas a uma finalidade estética. As proporções adotadas seguem os pressupostos considerados ideais matemáticos. Toma-se aqui como base a análise comparativa realizada por Colin Rowe para a Casa Foscari (1550-1560) de Palladio em Malcontenta, Itália, e a Casa Stein (1927) de Le Corbusier em Garches, na França (figura 118)

As análises aparentam "um pouco grotescas por terem tão poucos pontos de semelhança entre suas formas e evocações" (ROWE, 1976, p.11). Entretanto, dizem respeito à distribuição das coordenadas básicas em proporções estabelecidas matematicamente: "cada casa mostra um ritmo alternado de intervalos espaciais duplos e simples; e ambos, lidos de frente para trás, mostram uma distribuição tripartida comparável de linhas de suporte" (ROWE, 1976, p.11). A fim de facilitar a leitura, foi adicionado um ensaio semelhante no qual pode-se observar o mesmo critério utilizado por Meister para o prédio do Palácio 29 de Março, com diferenciações nas proporções para as fachadas norte e sul, que seguem regularidade fiel ao módulo (figura 118).

Nas fachadas laterais e internas aos terraços, os caixilhos piso-teto, encerram planos verticais em ambos os lados dos pilares (figuras 119 e 122). Desse modo, o desenho da estrutura é visualmente evidenciado pelas esquadrias que, pelo uso do vidro, durante o dia funcionam como vazios e a noite como cheios. Ao contrário acontece com os planos opacos no meio do vão. Em suma, o espaço da fachada entre estruturas é pautado e dividido verticalmente em quatro partes a partir do módulo, com tratamentos diferentes entre as soluções no térreo e nos demais pavimentos superiores. Tal solução foi amplamente utilizada por Meister em outros projetos, como por exemplo no Teatro Guaíra (1948), no Centro Politécnico da UFPR (1956), no Edifício Lydio Paulo Bettega/FIEP (1962) (figura 120) e Sede da Celepar (1964) (figura 121). Este princípio não apenas comunica a modulação à sua expressão plástica, mas confere continuidade ao espaço quando somado à padronização das soluções utilizadas internamente, como paginação de forros e pisos. 


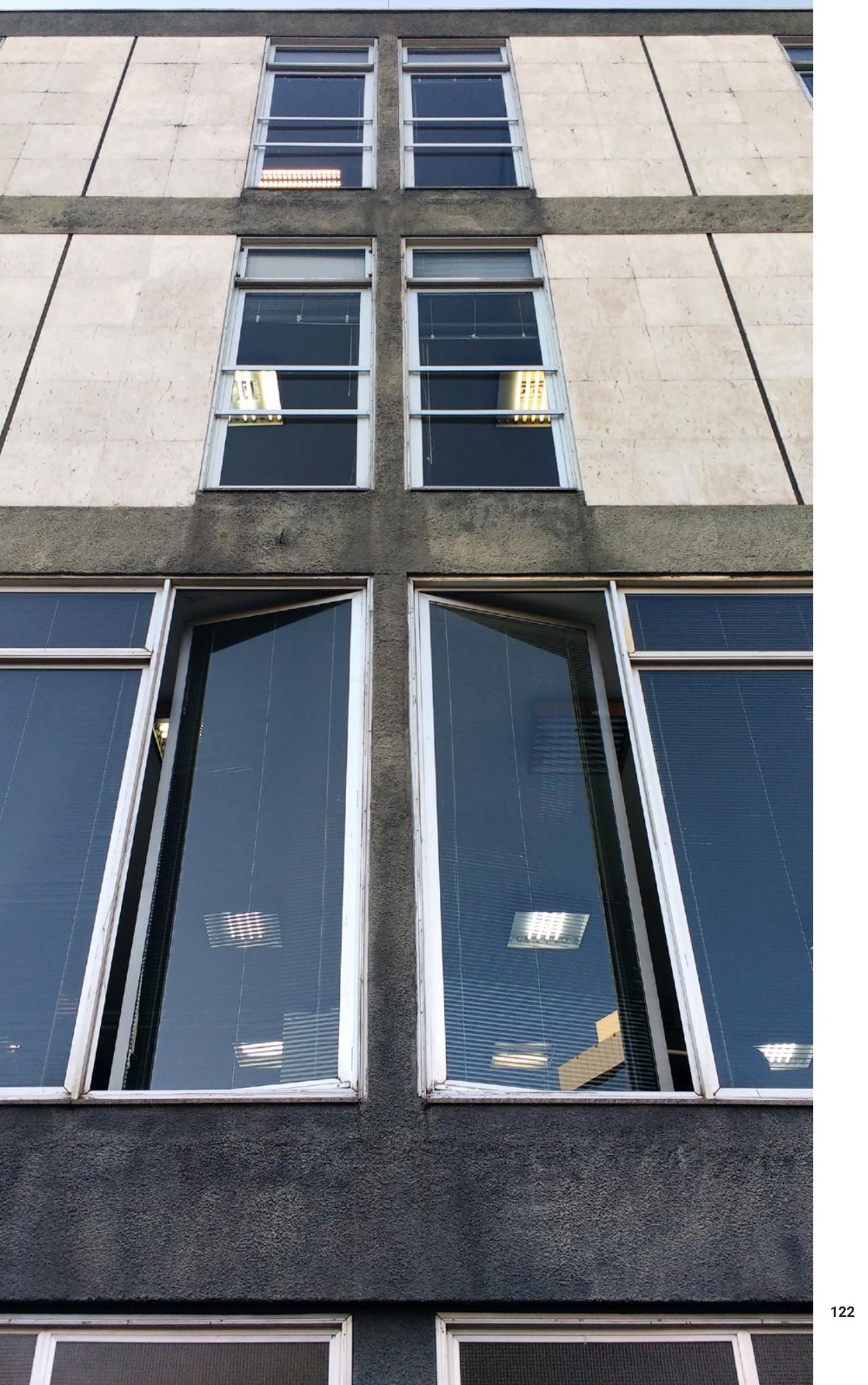


Figuras 123, 124, 125, 126 e 127: A

materialidade aplicada às fachadas do

Palácio 29 de Março. Da esquerda para a

direita' o concreto texturizado e pintado da

estrutura, o mármore travertino paginado

o revestimento em pedra do embasamen-

to, a pintura branca na fachada oeste (na

mesma posição do painel da fachada prin-

cipal) e o piso em granito do pavimento

térreo. Fonte: Acervo do auto

Figura 128 (página seguinte à esquerda): A relação entre os materiais e texturas nas fachada oeste. Fonte: Acervo do autor.

Figura 129 (página seguinte à direita):A conformação da materialidade na fachada sul nos planos em vidro translúcido, na estrutura em concreto escuro, nas esquadrias em aço natural, nos painéis em marmore travertino e no embasamento revestido em pedra. Fonte: Acervo do
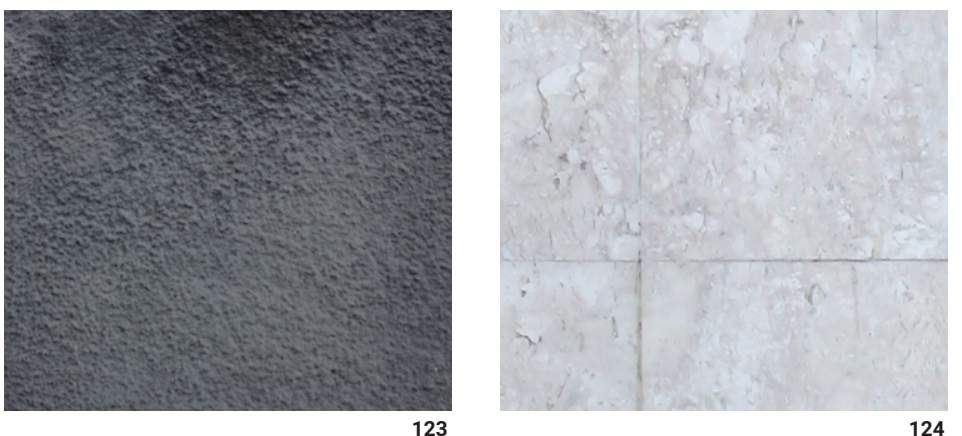

\section{Materialidade}

Os materiais empregados ao projeto são segmentados conforme sua função. O destacado e escuro "esqueleto" do prédio, presente em todas as manifestações estruturais do ponto de vista externo, é em concreto aparente que acabou adquirindo aspecto texturizado e foi pintado em sua execução. As esquadrias são em aço na cor natural, já internamente os pisos são em granilite no térreo e tacos de madeira nos pavimentos superiores e alguns lugares do subsolo. Os pilares dentro da edificação foram revestidos em lâminas de madeira, a mesma utilizada nas luminárias, desenhadas pelo próprio Rubens Meister. As vedações opacas das fachadas norte e sul são em placas de mármore, paginadas conforme o módulo, enquanto que nas empenas leste e oeste foram previstos painéis cerâmicos e pintura branca. Todo o edifício é sustentado por uma base de pedra que reveste as paredes externas afloradas do subsolo.

Prevendo aqui novamente a integração das artes, Meister reservou às empenas cegas das três barras voltadas à Avenida Cândido de Abreu a inserção de um painel artístico aos moldes do realizado por Poty Lazzarotto no Teatro Guaíra. Houve então um concurso logo após a finalização da obra em 1969, sendo o júri composto pelo próprio Rubens Meister, outros arquitetos como Leo Grossman e artistas como Erbon Stenzel. Por questões técnicas relacionadas à superfície da parede não houve escolha de uma proposta vencedora. A execução de um painel cerâmico só ocorreu 27 anos depois, quando em 1996 o poder público convocou a artista carioca Marília Kranz (1937 - 2017)
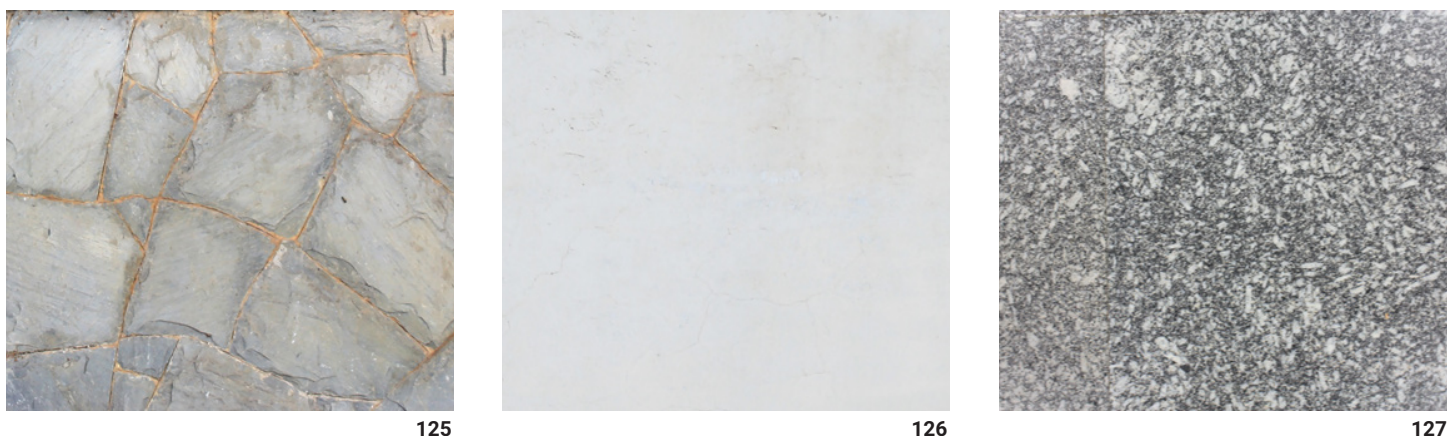

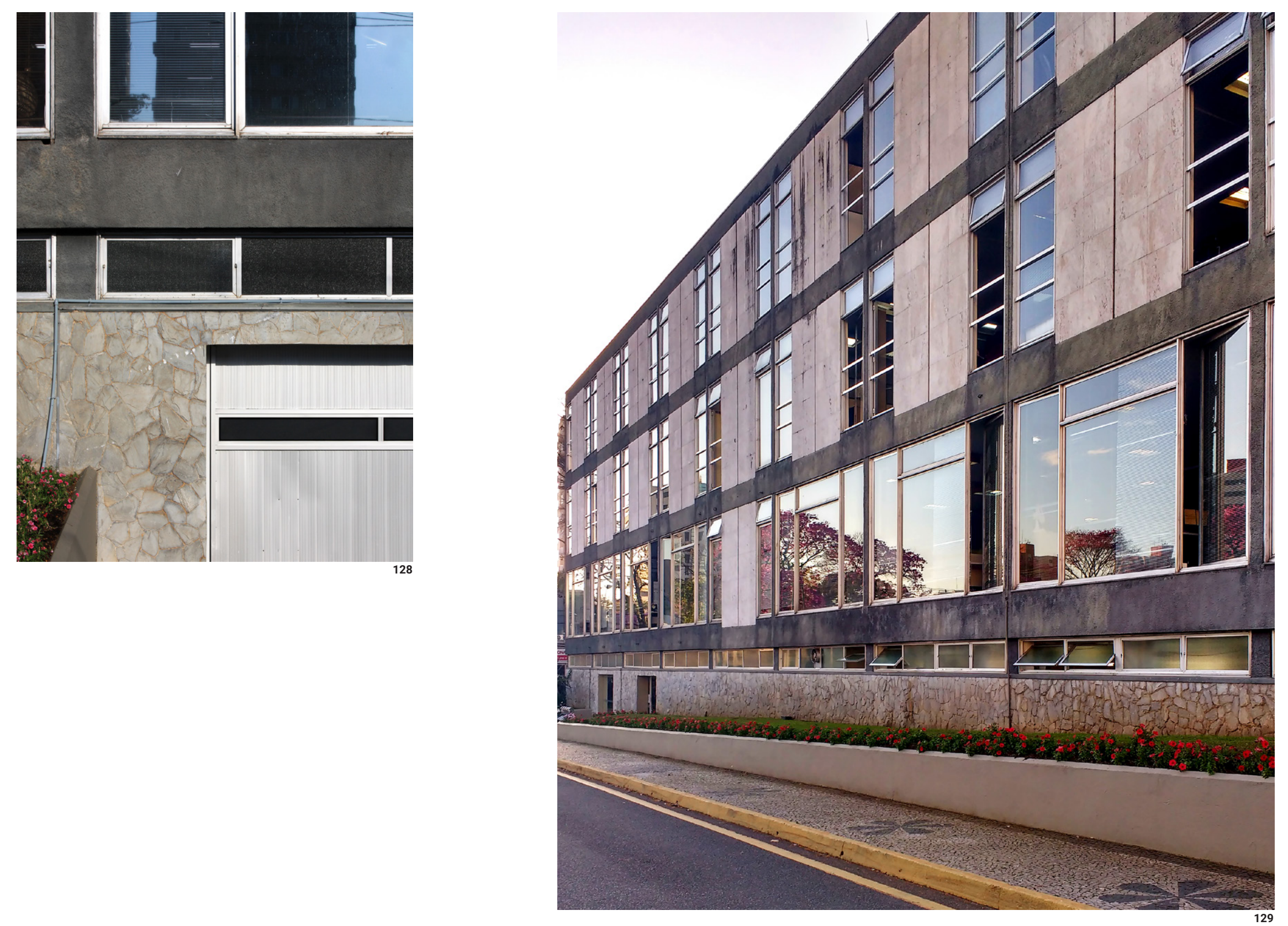


\section{Conclusões}

O Palácio 29 de Março é um franco exemplo de uma fase em que Meister buscava obter expressão arquitetônica máxima em suas obras através da lógica estrutural. A busca pelo belo a partir da técnica e os desdobramentos espaciais gerados a partir da singularidade do módulo apresentam-se de forma clara e explícita através das soluções mais variadas, cabendo aqui destacar o desenho da estrutura externa. O modo como a mesma é apresentada não se restringe apenas a valorização visual da solução estrutural em si, mas na sábia manipulação do seu desenho. As linhas do "esqueleto" amarram as diferentes peças criteriosamente dispostas entre os pavimentos e conferem uma unidade concisa e uma nova identidade ao artefato.

Há, no entanto, outras questões importantes: o poder municipal de Curitiba funcionava de forma desmembrada quando tinha sua sede no Paço da Liberdade e "somente de aluguéis a prefeitura pagava uma fortuna" (MORAES, 1969 apud CARVALHO; BATISTA; CHIESA, 2019, p. 187) para abrigar seus outros setores. A aglutinação era benéfica para as atividades internas $e$ era esperada uma resposta positiva vinda do público. A nova edificação, prevista para o Centro Cívico, traria uma cara nova e moderna à administração municipal. Virtudes como progresso, eficiência e transparência puderam ser transmitidas aos cidadãos através da arquitetura realizada, o que era prerrogativa do poder público.

A partir dos guardados de Meister referentes ao projeto para o Palácio 29 de Março têmse uma única versão anterior que contemplava a torre anexa de dez pavimentos como parte integral do projeto, sem novas etapas. Quanto à evolução da planta, ligeiras diferenças foram identificadas como na distribuição de núcleos de áreas molhadas e no acesso principal único e centralizado, abrigado por uma marquise de módulos hexagonais (como um experimento de um raciocínio projetual que viria a se concretizar nos anos 1970), destoante do restante do complexo. Contudo, os princípios norteadores do projeto mantiveram-se os mesmos. 


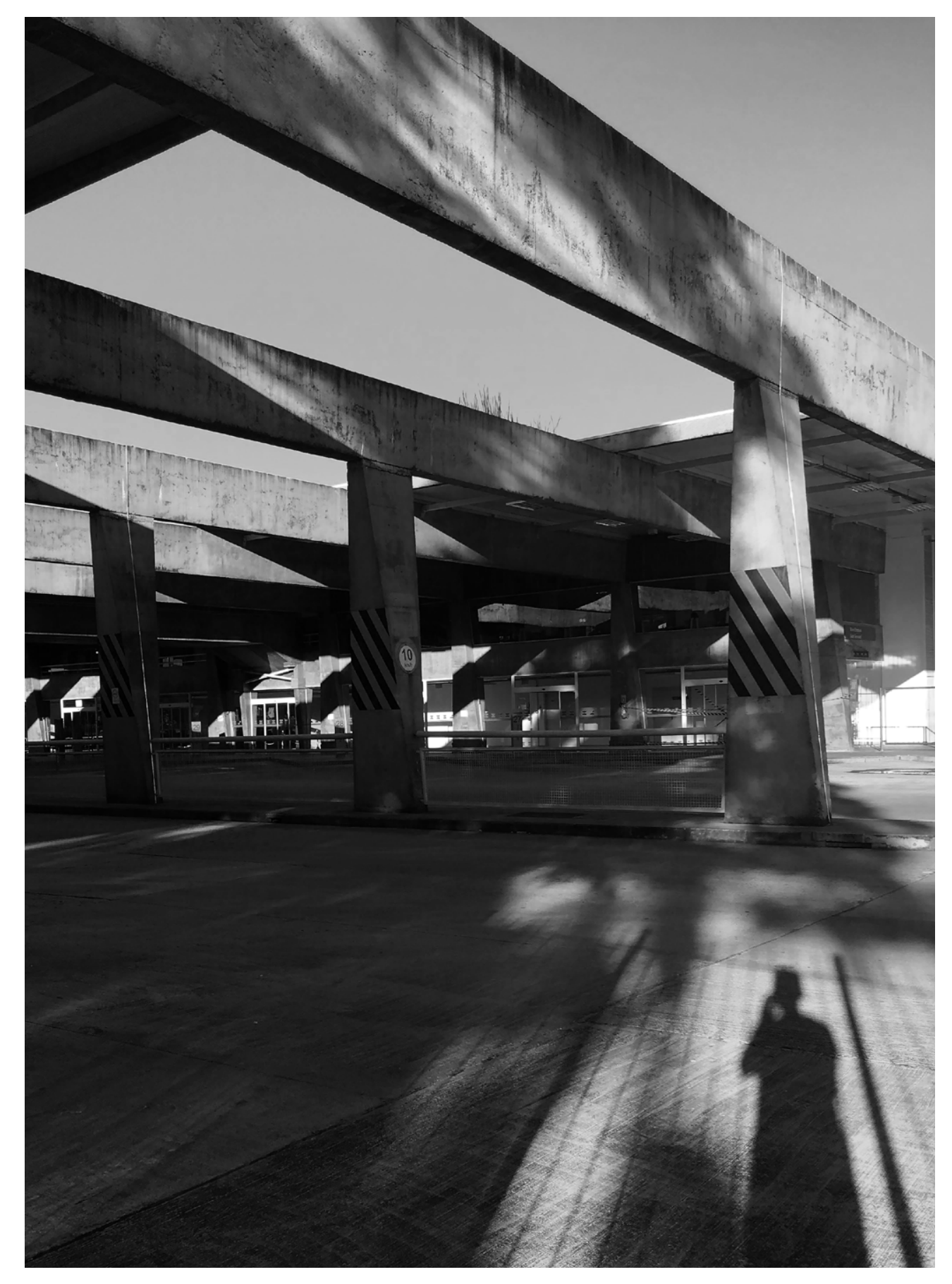




\section{Área}

Urbanização - $67.000 \mathrm{~m}^{2}$

Plano - $32.000 \mathrm{~m}^{2}$

\section{Localização}

Avenida Presidente Affonso Camargo, 330 Curitiba, PR

\section{Cliente}

Prefeitura Municipal de Curitiba

Rede Ferroviária Federal (RFFSA)

\section{Ano de projeto}

1969

\section{Ano de construção}

$1970-1972$

\section{Gabarito}

2 pavimentos

\section{Colaboradores}

Osiris Lepca, Erich Nissen 


\section{Introdução}

A Estação Rodoferroviária foi encomendada pelo então prefeito de Curitiba Omar Sabbag em 1969 com o objetivo de integrar os serviços de trens e ônibus que abasteciam a capital e substituindo as antigas estações. Rubens Meister não havia sido o primeiro a ser contactado e acabou sendo o terceiro profissional a elaborar um estudo para o local

O terreno do complexo está diretamente relacionado aos trilhos que cortavam a cidade de Curitiba a sul da região central. Encontra-se em área que anteriormente recebia o encontro de duas estradas de ferro, destinada ao pátio de manobras da Rede de Viação Paraná-Santa Catarina, em frente à Avenida Presidente Affonso Camargo.

Em 2014, ano da Copa do Mundo no Brasil, a obra sofreu intervenções pelo Instituto de Pesquisa e Planejamento Urbano de Curitiba (IPPUC) com projeto de autoria da arquiteta Celia Bim. A reforma visou melhorias em seu funcionamento, o que acarretou mudanças significativas em algumas soluções originais executadas, principalmente no terminal rodoviário: a caixilharia foi trocada, os guichês e alguns comércios mudaram de posição e escadas rolantes e forros foram adicionados

Rubens Meister havia elaborado outros dois projetos relacionados à infraestrutura de transportes em momentos anteriores: a antiga Rodoviária de Curitiba (1956) e a Rodoviária de Joinville (1968).

De notável relevância entre os projetos do engenheiro-arquiteto, a Estação Rodoferroviária de Curitiba é um dos poucos exemplares na temática de infraestrutura a aparecerem com frequência nas publicações de suas obras. 


\section{Análise de projeto}

\subsection{IMPLANTAÇÃO E RELAÇÃO COM A CIDADE}

\section{Contexto}

O transporte ferroviário no estado do Paraná teve surgimento em 1883 com o início da construção da estrada de ferro Curitiba-Paranaguá e da conclusão da estação de Curitiba em 1885. A posterior expansão com destino a Ponta Grossa em 1891 e consequente abertura ao interior representou o fim do isolamento de Curitiba com o restante do Paraná e posteriormente com outros estados. A primeira conexão interestadual ocorreu em 1910 através da estrada de ferro São Paulo-Rio Grande do Sul que passava por Ponta Grossa e permitiu acesso facilitado às cidades de São Paulo e Rio de Janeiro.

O terreno de implantação da Estação de Curitiba (figura 132) foi escolhido a sul da cidade, abaixo do encontro dos Rios Ivo e Belém, em ponto de rápido escoamento da madeira e ervamate para os navios em Paranaguá (figuras 134, 135 e 136)

"Em 1880, um dos responsáveis pelas obras da estrada de ferro, o engenheiro Antonio Ferucci, determinou o local para a ferroviária, num eixo que uniria o centro do edifício à rua em frente. (...)

(...) A partir da inauguração da ferrovia Paranaguá-Curitiba, em 1885, residências e comércios começaram a margear o eixo concebido por Antonio Ferucci."

(DUDEQUE, 2010, p.23-25)

A "rua em frente" à estação chamava-se Rua da Liberdade (figura 131), hoje Barão do Rio

Figura 131: Rua da Liberdade com a Estação de Curitiba ao fundo na recepção do Presidente Afonso Pena em 1909 Disponivel em: <http://especiais.gaze tadopovo.com.br/ferrovia-130-anos/estacao-de-curitiba>. Acesso em: 16.dez.2019.

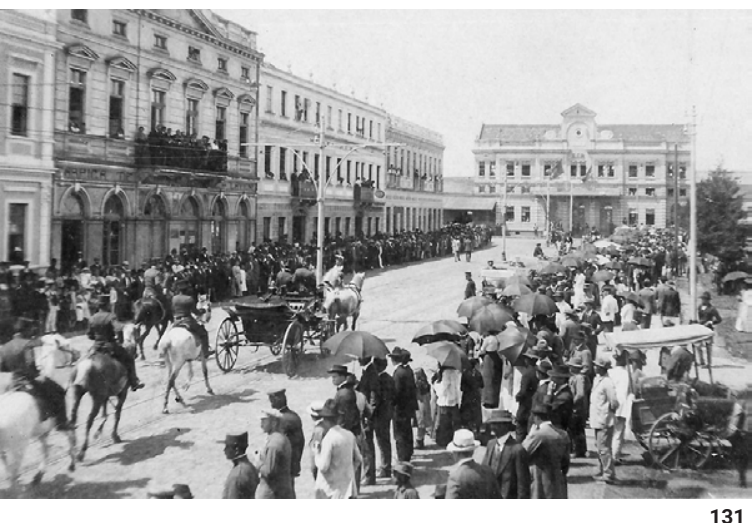


Figura 132 (acima): Estação Ferroviária de Curitiba em 1930. Disponivel em: <http:/ especiais.gazetadopovo.com.br/ferrovia-130-anos/estacao-de-curitiba>. Acesso em 16.dez.2019.

Figura 133 (abaixo): Rodoviária de Curitiba (1956), atual Terminal Guadalupe. Fonte: Acervo do autor
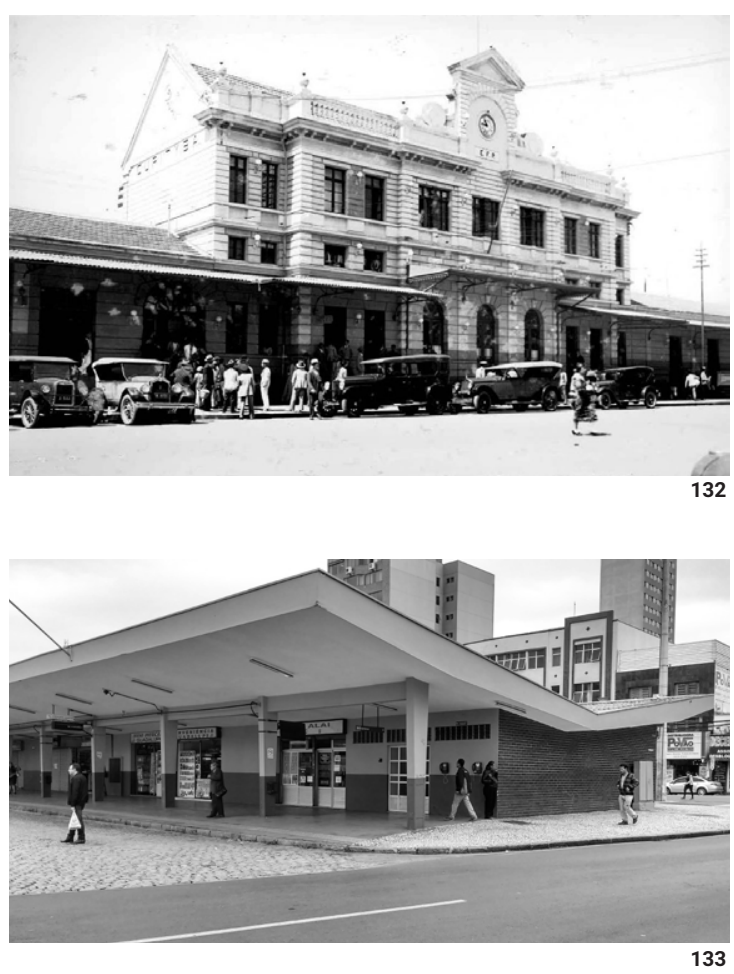

Branco, e tem sua origem na Praça Generoso Marques, local onde estava situado o Mercado Novo, principal ponto de comércio e troca de produtos na época. A partir da demolição do mercado, este importante eixo estrutural consolidou o seu papel cívico com a construção do Paço Municipal, sede da Prefeitura de Curitiba, em 1916 na mesma praça. Nessa rua funcionava desde 1890 a antiga sede do governo estadual, o Palácio da Liberdade (atual Museu da Imagem e do Som), e a Assembleia Legislativa do Estado do Paraná desde 1895, o Palácio Rio Branco (atual Câmara Municipal de Curitiba).

O local da estação, em um dos limites urbanos e de campos planos, acabou sendo propício para a formação de uma área industrial no bairro Rebouças, à sul e aos fundos do edifício, que veio a crescer consideravelmente nos anos seguintes (figuras 134, 135 e 136). O contrário ocorreu na direção sudeste, ponto de encontro entre as estradas de ferro (e também pátio de manobras) e do Rio Belém dentro do perímetro urbano.

"Nas décadas seguintes, os terrenos da ferrovia, as indústrias e o Rio Belém criaram uma barreira aos avanços urbanos."

(DUDEQUE, 2010, p.27)

Foi em 1972, com a conclusão da nova Rodoferroviária, que o último trem saiu da Estação de Curitiba para Paranaguá, sendo que em 1990 teve suas últimas conexões sobre trilhos (com a estrada de ferro para Ponta Grossa e com a própria Estação Rodoferroviária) desfeitas. Hoje a edificação encontra-se preservada, bem como os trilhos restantes em frente à plataforma, e funciona como o Museu Ferroviário de Curitiba. No entanto, o espaço perdeu importância como um marco visual na cidade com a construção de um grande shopping (no terreno ao lado e nos fundos, junto aos trilhos) no final dos anos 1990

Destino diferente teve antiga Rodoviária de Curitiba (figura 133), na Praça Senador Correia frente para a Rua João Negrão, projetada pelo próprio Rubens Meister em 1956 e finalizada 

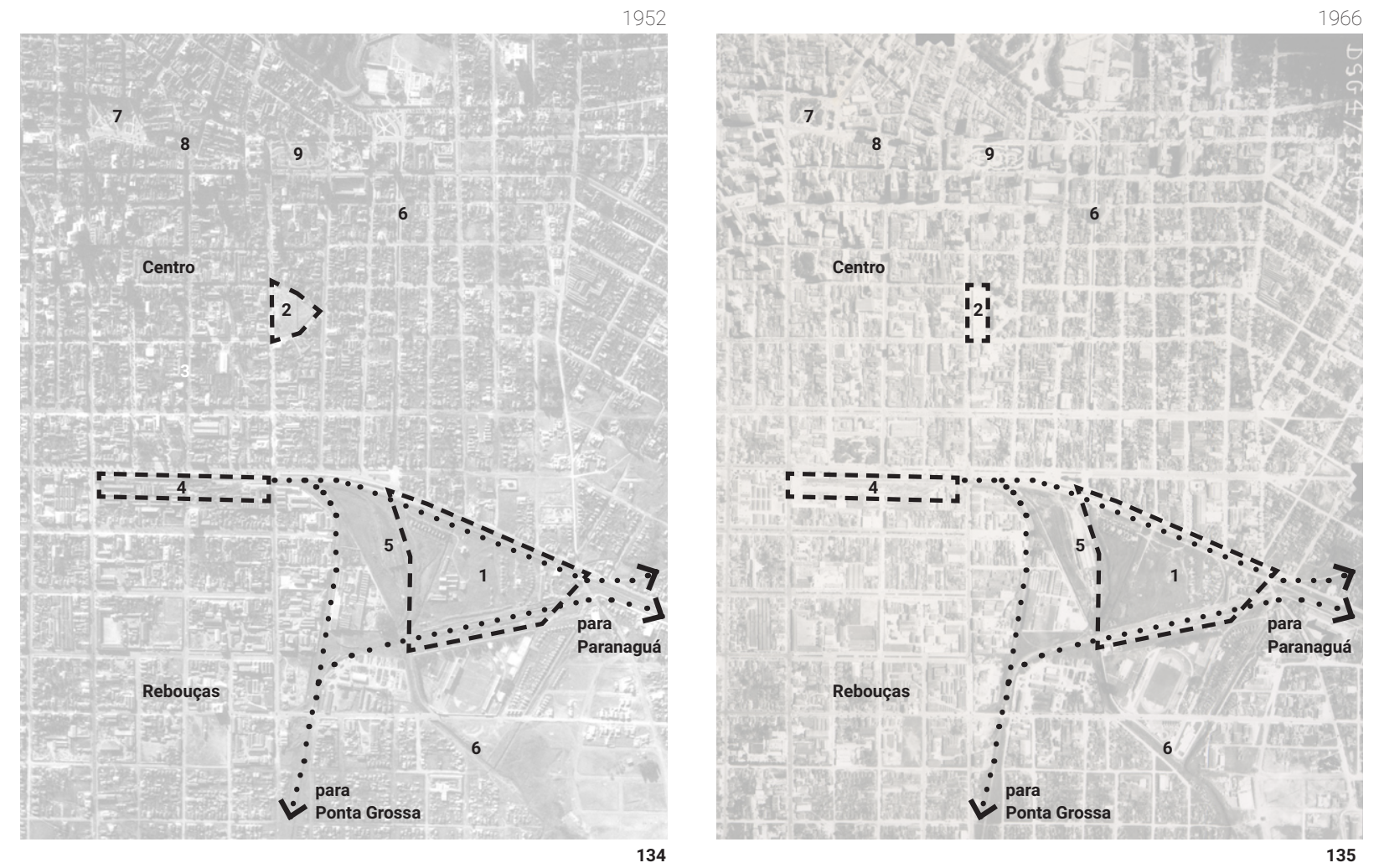

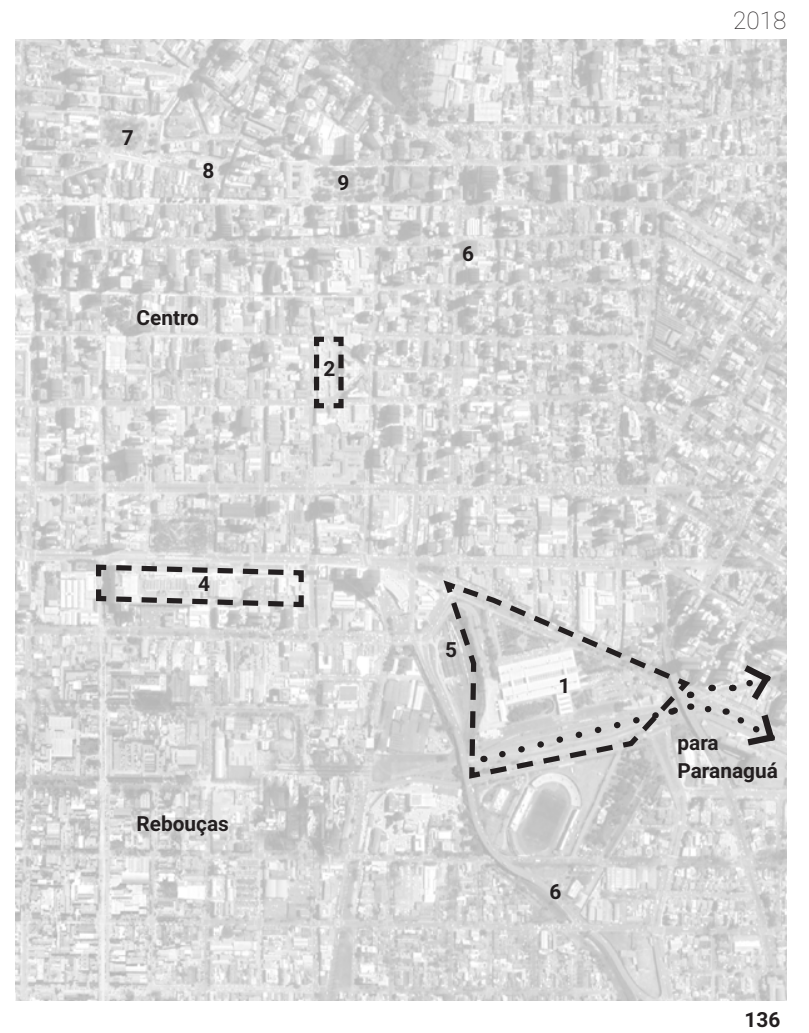

136

$0^{N}$

1 Pátio de manobras | Terreno Rodoferroviária

(ária (1956-1972)

3 Rua da Liberdade Rua Barão do Rio Branco

4 Estação Ferroviária Curitiba (1885-1972)

$\begin{array}{ll}\mathbf{5} & \text { Galpões } \\ \mathbf{6} & \text { Rio Belér }\end{array}$

7 Praça Tiradentes

8 Praça Generoso Marques 
Figura 134 (página anterior à esquerda): Vista aérea parcial de Curitiba em 1952 com destaque para o terreno da Estação Rodoferroviária. Fonte: Acervo do Instituto de Pesquisa e Planejamento Urbano de Curitiba (IPPUC) e editado pelo autor

Figura 135 (página anterior ao centro): Vista aérea parcial de Curitiba em 1966, quando já se haviam estudos para uma nova estação integrada. Fonte: Acervo do Instituto de Pesquisa e Planejamento Urbano de Curitiba (IPPUC) e editado pelo auto

Fiqura 136 (página anterior à direita): Vista aérea parcial de Curitiba em 2019. Fonte: Imagem de satélite do Google Earth e

editado pelo autor. em 1958. Em torno de apenas uma década após a sua construção, a cidade sentiu as demandas consequentes de um rápido crescimento que obrigou o poder público a pensar em uma alternativa em maior escala para os ônibus interestaduais e intermunicipais que saíam e chegavam na capital. A rodoviária esteve em funcionamento por 14 anos e, assim como a estação de trens, teve a sua função transferida para o novo complexo Rodoferroviário em 1972. Entretanto, o edifício acabou sendo adaptado ao sistema de ônibus metropolitano de Curitiba que conecta o centro às cidades vizinhas, hoje conhecido como Terminal Guadalupe.

A integração dos transportes ferroviários e rodoviários em um único equipamento e a sua localidade foram previstas no plano do urbanista Jorge Willheim junto ao Instituto de Pesquisa e Planejamento Urbano de Curitiba (Plano Willheim-IPPUC, 1965). A posição era estratégica, um lote grande à margem leste do Rio Belém, que já antes comportava uma considerável trama de trilhos e muito próximo à antiga Estação de Curitiba. A via de acesso, Avenida Presidente Affonso Camargo, possui conexão com cidades da região metropolitana e com a Rodovia Régis Bittencourt (BR-116, saída para o estado de São Paulo). A avenida se origina de uma inflexão da Avenida Sete de Setembro, importante eixo estrutural de transporte público da capital, formando um entroncamento junto do acesso à Avenida Comendador Franco (saída para o estado de Santa Catarina através da BR-376) e Avenida Prefeito Omar Sabbag (saída para o litoral do Paraná através da BR-277). A medida que a cidade foi se verticalizando nos arredores, o terreno entre as manobras dos trilhos permaneceu o mesmo por décadas (figuras 134, 135 e 136).

Anterior ao projeto de Meister outros dois estudos foram realizados para o complexo rodoferroviário, o de Sérgio Bernardes em 1967 (figura 137) e do próprio IPPUC em 1968 (figura 138), presidido por Jaime Lerner e que contava com Rafael Dely, Domingos Bongestabs e Joel Ramalho Jr. na equipe de arquitetos (CARVALHO; BATISTA; CHIESA, 2019, p.267). Ambas as propostas trabalhavam o terreno de diferentes maneiras: a de Bernardes consistia em um complexo inserido dentro de uma geometria circular e com uma torre de telecomunicações em seu centro, enquanto a do IPPUC propunha uma separação das estações em dois blocos, sendo 
um deles curvado (e côncavo perante a Avenida Presidente Affonso Camargo) próximo ao seu centro que concentrava um saguão de usos comuns aos dois terminais.

\section{Relação com a paisagem urbana}

Ligeiramente fora do eixo da Avenida Sete de Setembro, o lote compõe uma porção da cidade que se encontra no limiar das atividades fabris e das residências de baixo gabarito. Para este lado sul da avenida, a transformação vertical da cidade teve pouca interferência na paisagem urbana com o passar das décadas. Pode-se dizer que o contrário ocorreu nos eixos estruturantes da Avenida Sete de Setembro, a oeste, e na continuidade da Avenida Affonso Camargo em direção ao bairro Cabral, a leste.

Vista à distância e ao nível do pedestre, a Rodoferroviária possui uma presença discreta no cenário urbano e marca a paisagem apenas através da torre do relógio e reservatório, único elemento vertical ante a extrema horizontalidade do complexo. Este efeito parece ganhar força ao se observar a sua posição entre dois viadutos nos limites sudoeste e nordeste, encerrando duas das três pontas do terreno (figura 139). Esta percepção sofre uma abrupta inversão ao se observar o projeto em sua totalidade, especialmente sob uma perspectiva aérea

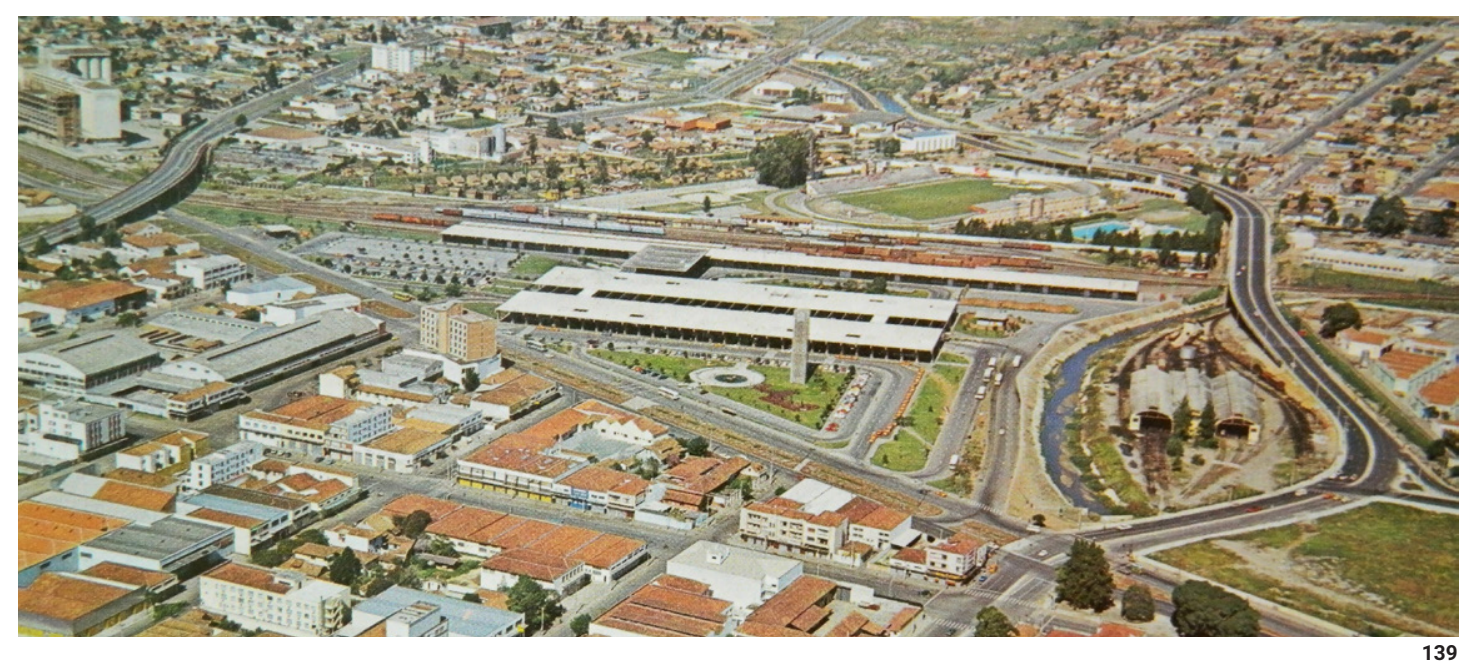

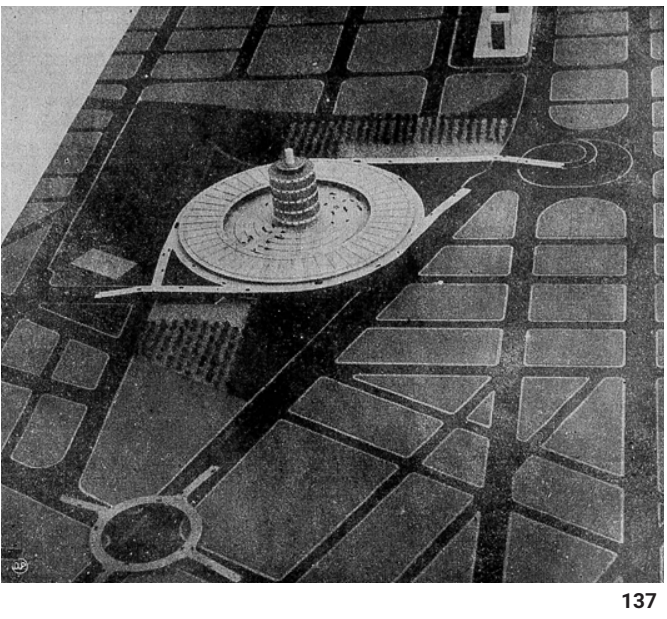

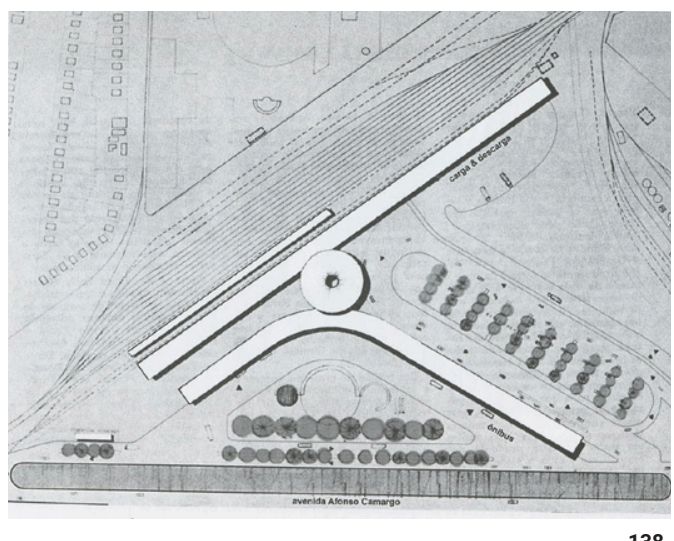

138

Figuras 137 e 138 (acima): Proposta de Sérgio Bernardes e a proposta do IPPUC para a Rodoferroviária. Fonte: CARVALHO BATISTA, CHIESA, 2019, p.266

Figura 139 (abaixo): A Rodoferroviária de Curitiba os viadutos limítrofes e o Rio Belém. Fonte: Acervo Rubens Meister 


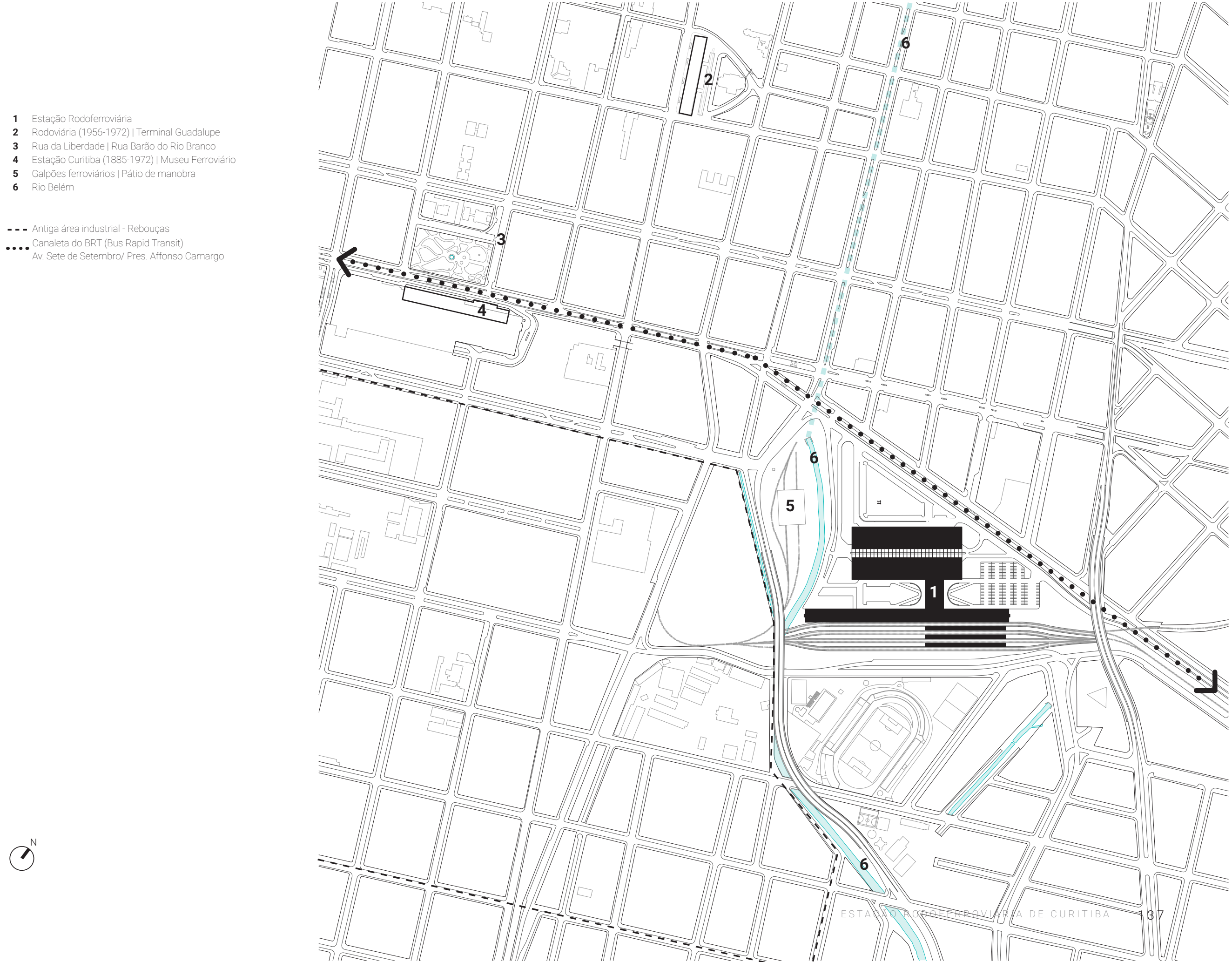




\section{Relação com o terreno}

Além dos limites irregulares do terreno, a condicionante que possivelmente norteou a solução de implantação foi a pré-existência dos trilhos e suas ramificações a sul, alinhados estes à passagem direta Paranaguá-Ponta Grossa e concorrente ao Rio Belém. Com a manutenção deste segmento e desativação do caminho que passava paralelo à Avenida Affonso Camargo, em frente ao lote, o posicionamento do terminal ferroviário parece estar em seu local mais adequado.

O bloco menor e intermediário serve como passagem na transição entre os modais. 0 terminal rodoviário, dividido em duas lâminas, possui dois setores: o setor sudeste, defronte o terminal ferroviário, corresponde ao bloco de conexão intermunicipal enquanto que o setor noroeste corresponde ao bloco que faz as conexões interestaduais.

A organização ortogonal e em barras distintas dos diferentes usos é atravessada por vias de circulação de ônibus e automóveis que precisam ou acessar ou deixar as estações separadamente. Entre as vias e no limite leste há bolsões de estacionamento e, junto à Avenida Presidente Affonso Camargo, foram reservados espaços verdes além de uma praça de chegada que abriga a torre do reservatório.

\section{Percursos externos e acessos}

Ao contrário do que se percebe no projeto do Palácio 29 de Março, a compreensão do todo na Estação Rodoferroviária não é imediata. É lenta e gradual. Em certos momentos e a partir da Avenida Presidente Affonso Camargo, principal via de acesso, não seria nenhum exagero confundir o espaço com um parque urbano tendo em vista a distância da edificação para uma das pontas do terreno e a massa arbórea presente na praça em frente (figura 141).

Logo, ao acessar os terminais de automóvel tem-se alcance direto a todas as plataformas a partir de acostamentos de embarque e desembarque, contando inclusive com uma rua subterrânea ("mergulhão") de conexão viária com o setor oeste do conjunto. Os acessos
Acima: A relação com o lote Fonte: Desenho desenvolvido pelo autor.

Figura 137 (meio): Vista aérea do complexo. Disponível em: <http://curitiba. pr.gov.br>. Acesso em: 22.jul.2018 Figura 138 (abaixo): Vista a partir da Avenida Presidente Affonso Camargo. Fonte Acervo do autor
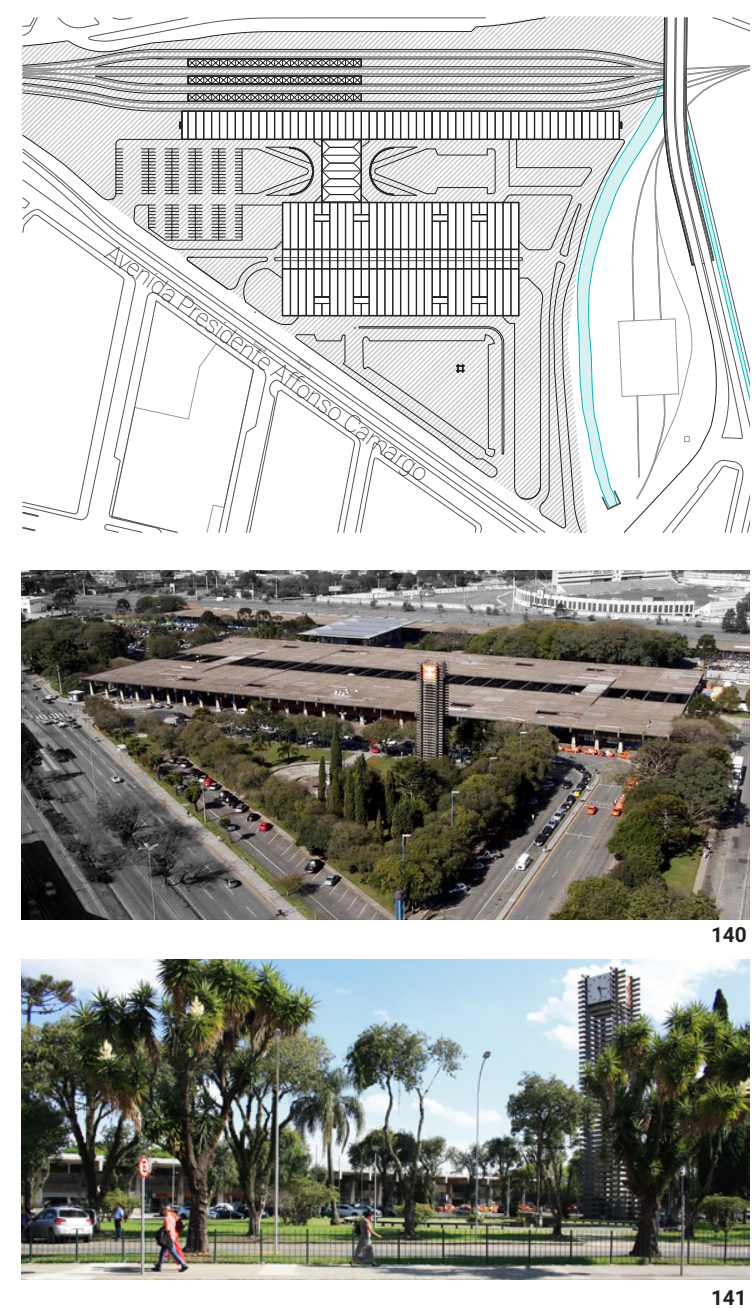
Figura 142 (à direita): Frente do bloco interestadual da Rodoferroviária na década de 1970. Fonte: Acervo Rubens Meister

Acima: Percursos e acessos à Rodofer

roviária Fonte: Desenho desenvolvido pelo autor

Abaixo: Sinalização das aproximações

Fonte: Desenho desenvolvido pelo autor.

Figuras 143, 144, 145, 146, 147, 148 e 149

(página seguinte) Vistas das aprox-

macõos. Fonte: Acervo do autor.

- . - Percursos

4-- Acesso pedestre

$\leftarrow$ Acesso automóveis

$\leftarrow$ Acesso ônibus
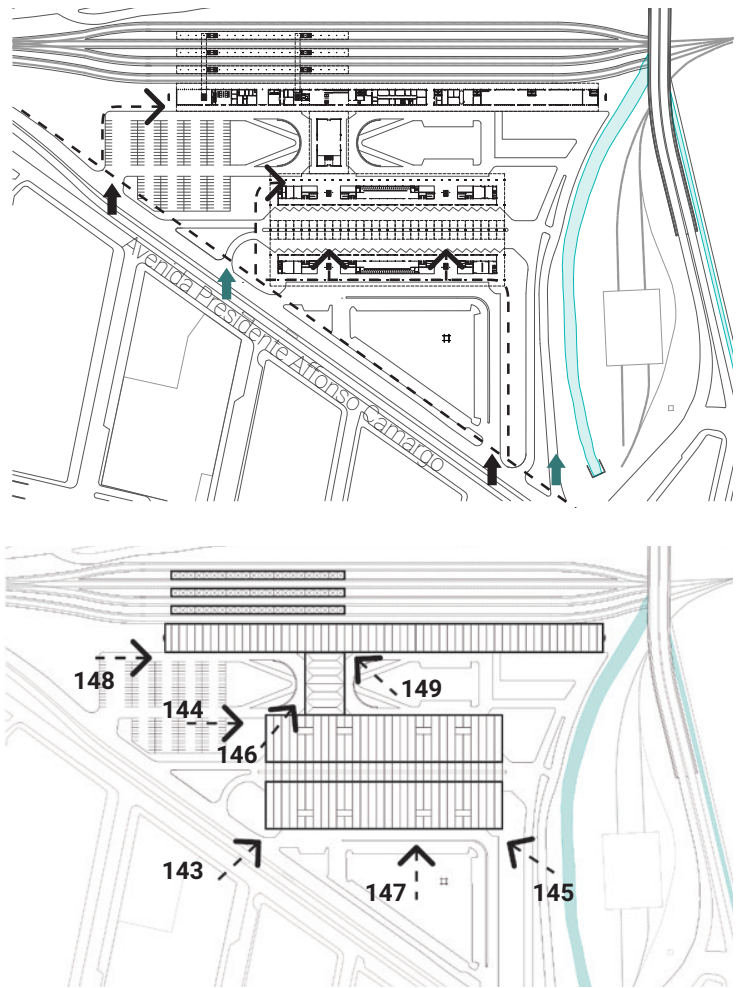

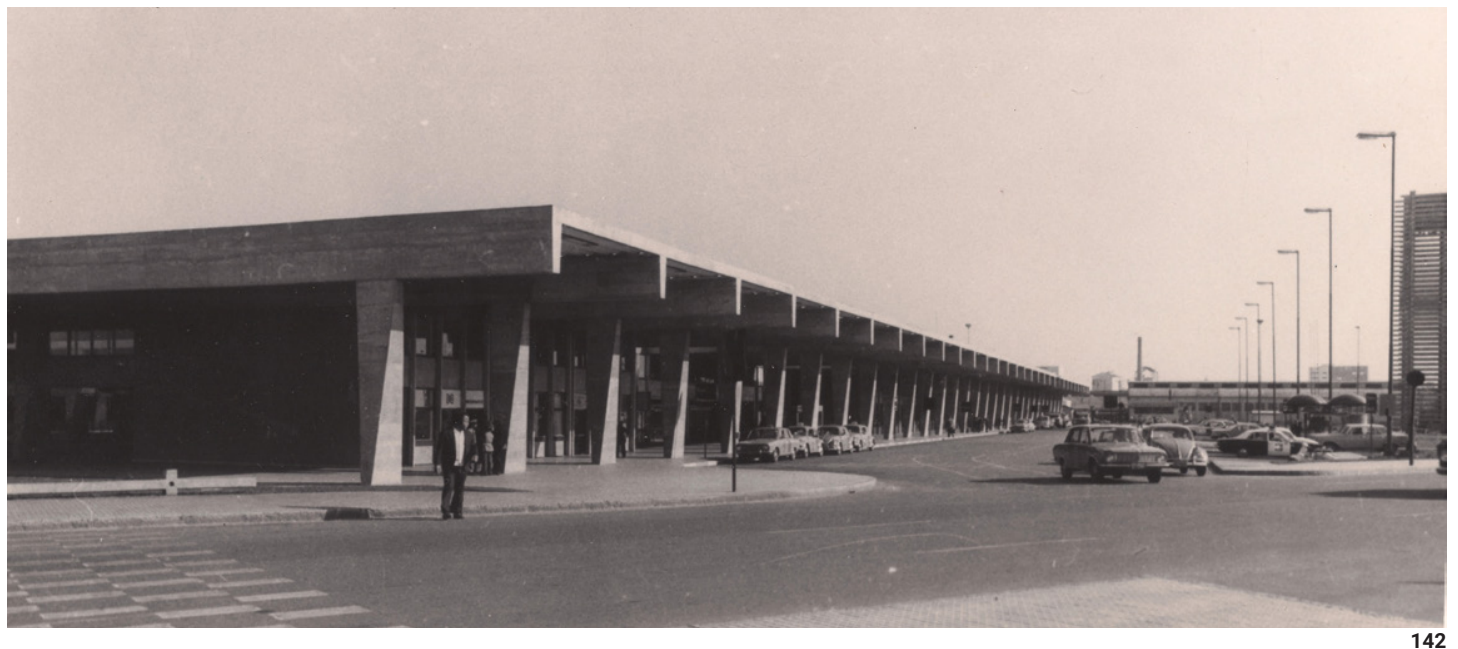

principais para o pedestre e para quem chega através do transporte público encontram-se essencialmente às pontas do bloco rodoviário interestadual e também próximo ao seu centro, com a praça em frente funcionando também como passagem.

Após uma aproximação pelas laterais, a sensação de infinitude dos pórticos da rodoviária toma grande protagonismo (figura 142). A marcação repetida das estruturas soltas das vedações confunde o acesso, caso a chegada não seja transversal ao edifício (figuras 143 e 145). Entendese aqui como "acesso" as duas passagens que levam ao interior do bloco rodoviário e também às travessias entre as partes interestaduais e intermunicipais. Compreende-se lentamente a localização destas entradas à medida que se aproxima do centro da edificação.

A travessia a nordeste do setor da rodoviária desemboca também em frente ao bloco intermediário de transição (figura 146). Ao centro deste bloco localiza-se um dos acessos que também podem ser realizados através de outras três portas, sempre ao centro de cada uma das fachadas. Esta edificação apesar de menor, é a mais alta do conjunto. A solução estrutural aqui permitiu beirais generosos que funcionam tanto como uma segura travessia de pedestres entre as estações, mas também como marquises de recepção das vias acima do "mergulhão" 

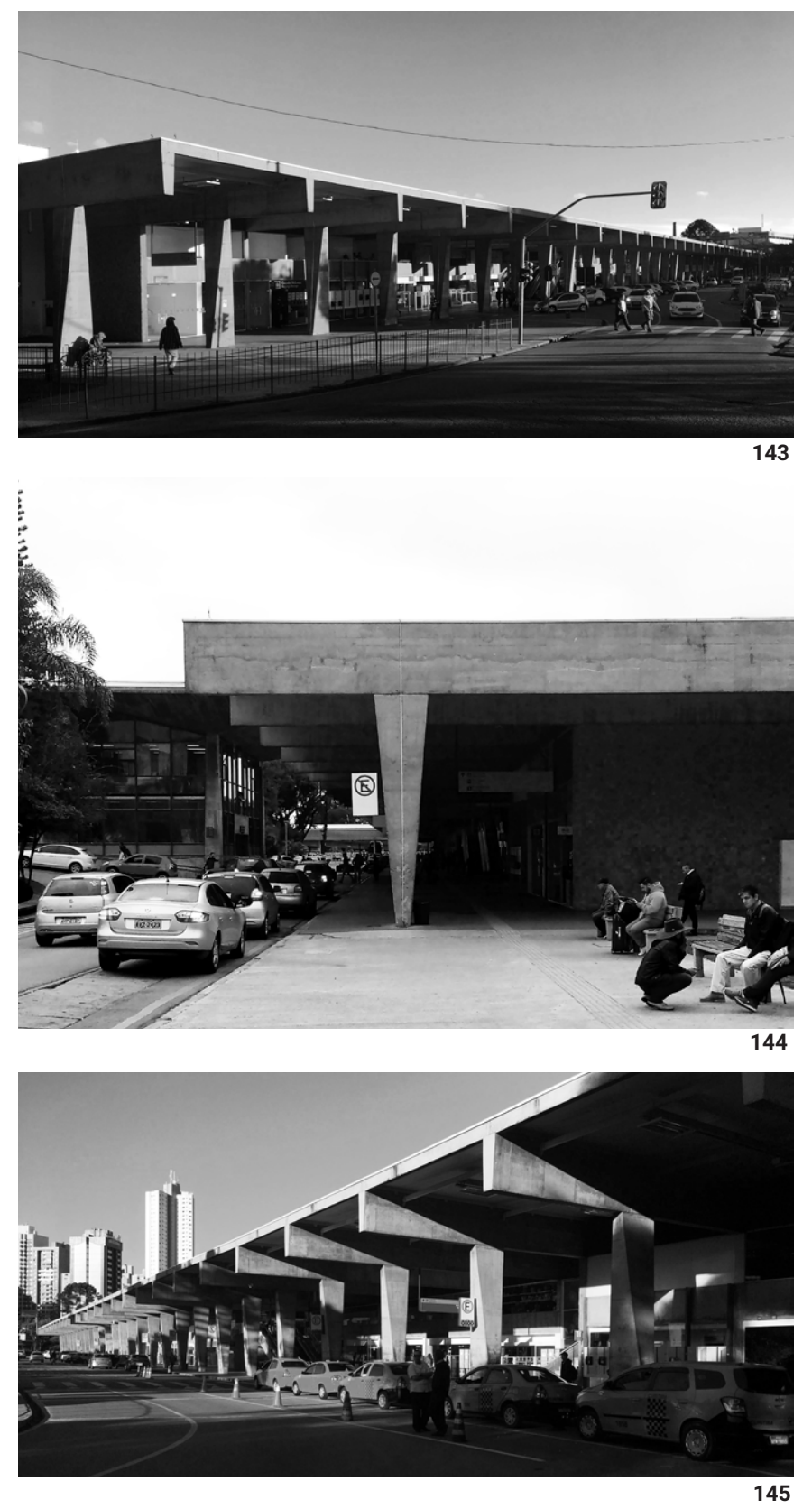
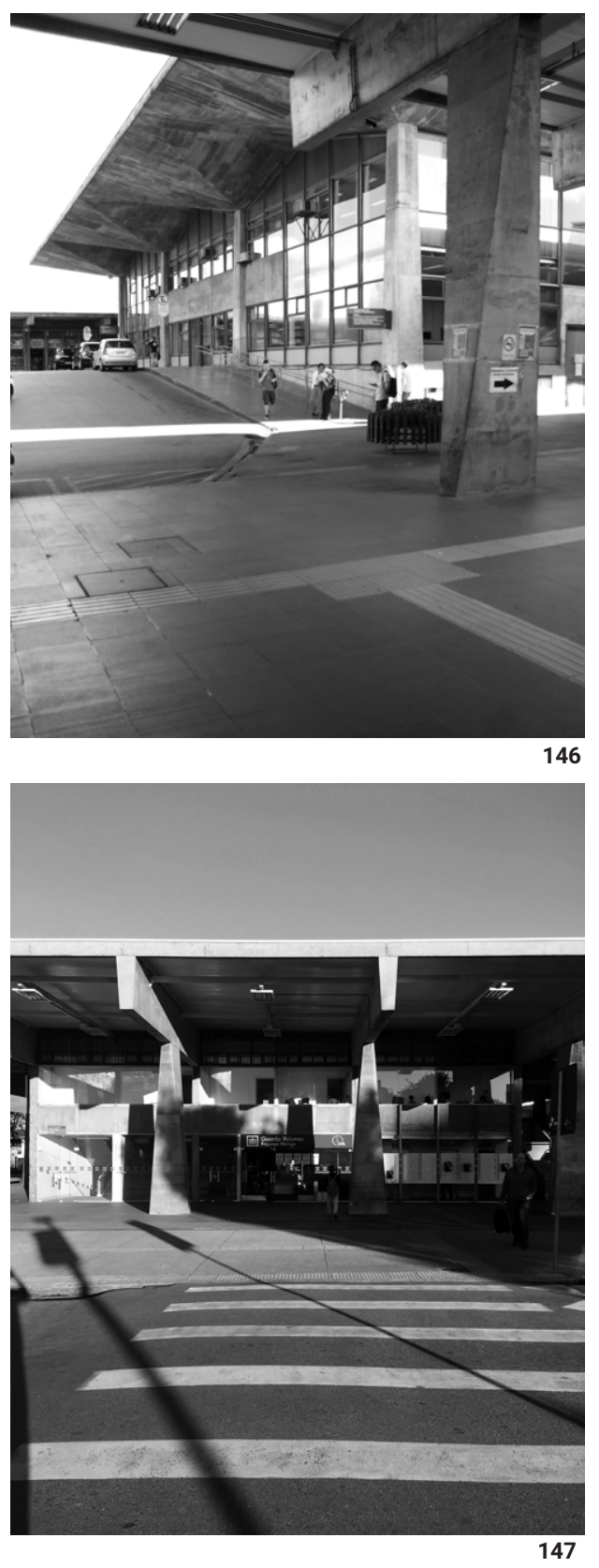
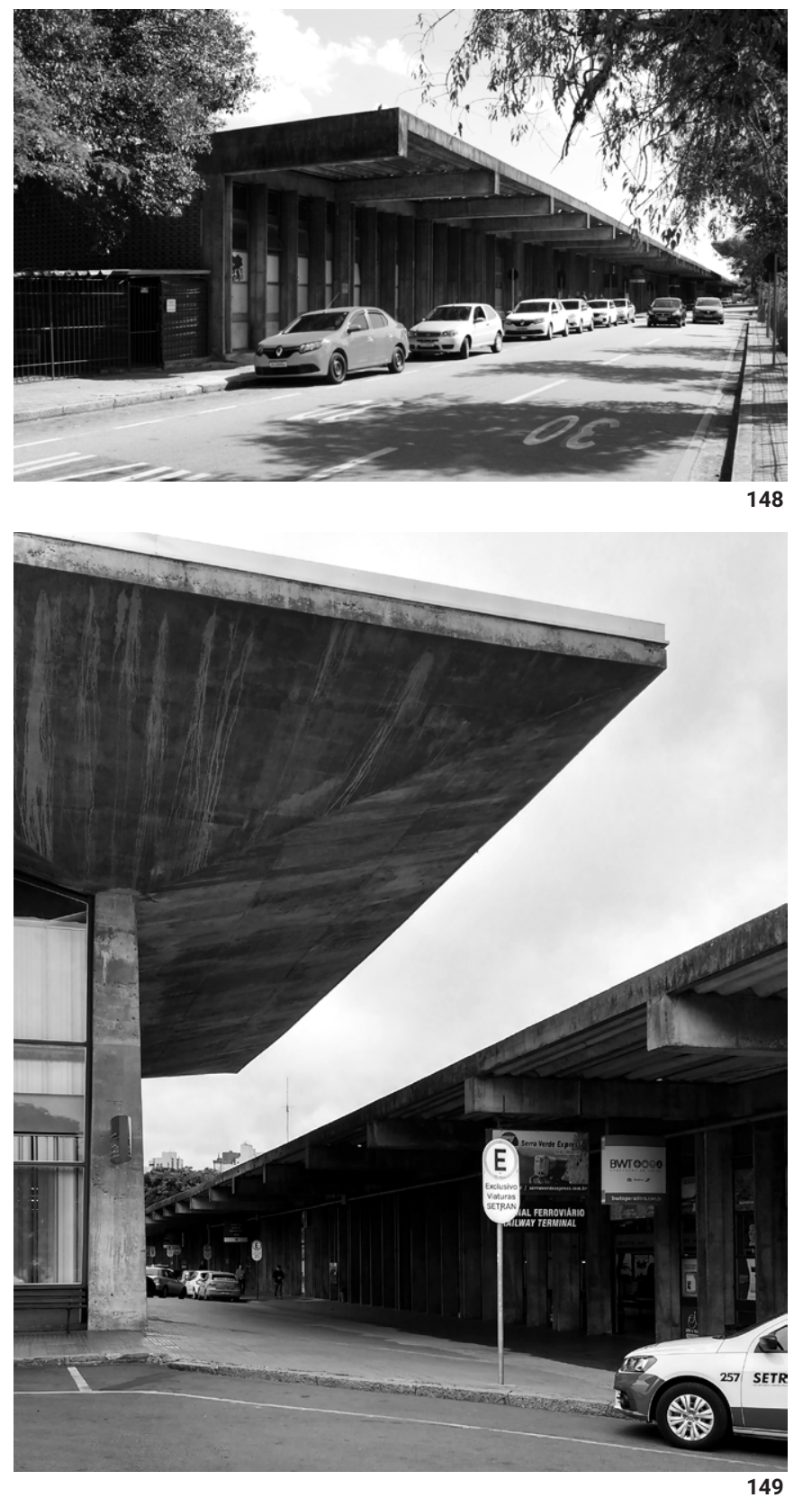
Planta acima: Trajetória solar sobre o

complexo. Fonte: Desenho desenvolvido

pelo autor

Plantas abaixo: Vistas externas no térreo

e primeiro pavimento respectivamente

Fonte: Desenho desenvolvido pelo autor
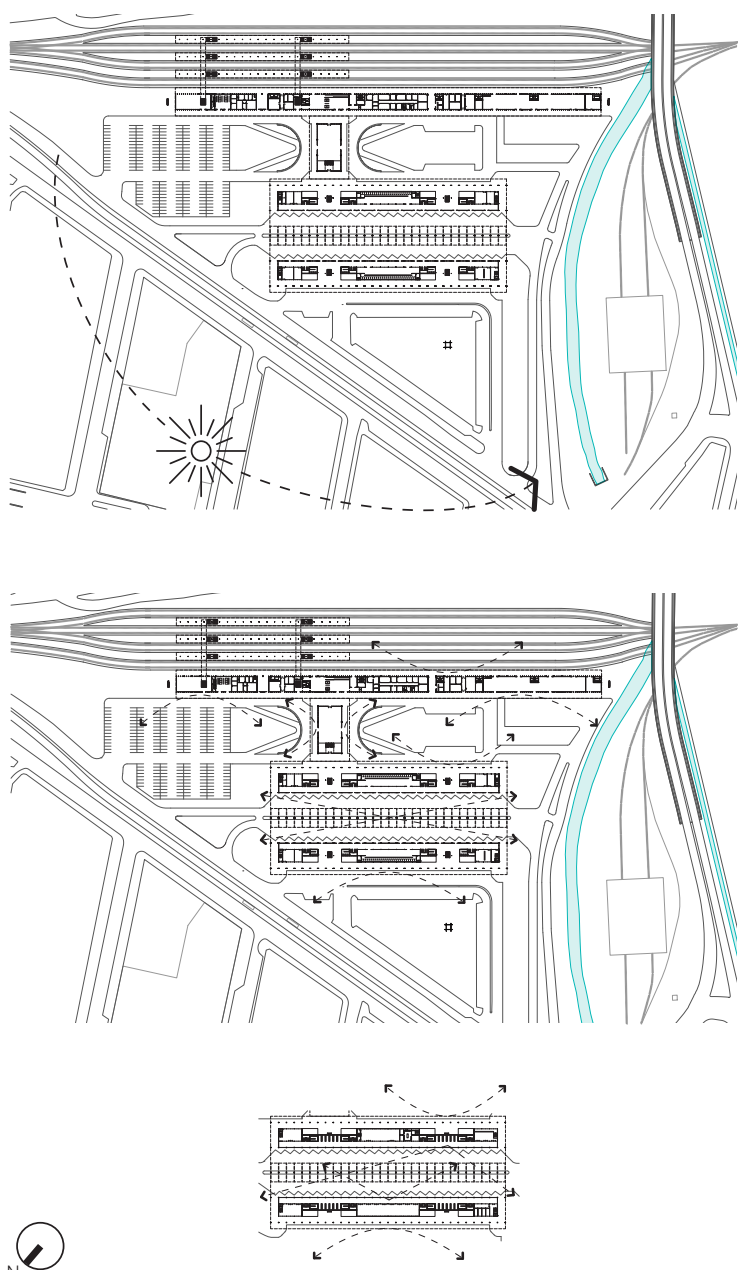

viário (figura 149)

O domínio visual do setor ferroviário é em partes comprometida pelo bloco intermediário, mas também pelo seu comprimento de 346 metros (figura 148). Há diferentes tipos de acessos para diferentes usos ao longo da barra, sendo todos abrigados pelo beiral estrutural dos pórticos de forma equivalente. Para estes, não há aqui uma rápida leitura e identificação.

O bloco intermediário se desenvolve como um elemento articulador entre as estações e funciona como uma espécie de marquise que organiza os fluxos e principais acessos. Encontrase ele em frente ao terminal ferroviário e também nos fundos do terminal rodoviário.

\section{Orientação, insolação e vistas}

A orientação da obra aparenta estar mais determinada pela organização das funções trilhos, plataformas de ônibus, embarques e desembarques - que pela posição solar ou das visuais externas. A estrutura porticada cria uma proteção solar discreta ao sol no centro das vias de abastecimento das plataformas de ônibus, em partes como funciona nos terraços-jardins do projeto para o Paço Municipal (1960). Os generosos beirais presentes nas três edificações protegem o usuário do tempo chuvoso e da insolação (figuras 144, 146 e 148), com exceção do sol poente nas fachadas voltadas à noroeste.

As vistas para o lado externo concentram-se mais nas plataformas de embarque e, em segundo plano, na área de desembarque dos veículos, principalmente para quem observa a partir do primeiro pavimento do terminal rodoviário. Nele, assim como no setor ferroviário, o programa organiza-se no sentido noroeste-sudeste e possui aberturas, translúcidas ou não, orientadas a estas fachadas. Pode-se destacar a preocupação de Meister em orientar as vistas sempre a uma massa arbórea em segundo plano, atrás das vias que circundam as edificações. A exceção fica por conta da orientação sudeste das plataformas da estação ferroviária. O encerramento destes blocos no sentido nordeste-sudoeste é opaco, com exceção do bloco intermediário que é equivalentemente aberto para todas as orientações. 


\subsection{FORMA, ESPAÇO E PROGRAMA}

\section{Programa e setorização}

Pode-se dividir o complexo em três setores: terminal rodoviário, setor de exposições e terminal ferroviário (diagrama baixo). o primeiro, dividido em duas alas (intermunicipal e interestadual), possui suas plataformas perimetrais externas voltadas ao embarque e desembarque de automóveis particulares e taxis, enquanto as plataformas internas são destinadas ao embarque e desembarque dos passageiros dos ônibus. Os programas posicionados nos quatro cantos abrigam serviços voltados aos usuários do terminal enquanto em seu centro localizam-se os guichês comerciais das companhias de ônibus voltadas à rua. Orientadas para o interior da edificação estão as salas de espera. Todo o pavimento térreo é destinado ao uso exclusivo de uma estação rodoviária enquanto o pavimento superior concentra o setor comercial, voltado ao usuário, como lojas e restaurantes.

O terminal ferroviário é dotado de uma fragmentação de uso um pouco mais acentuada tendo em vista a organização em uma barra longitudinal térrea. Os acessos à plataforma e salas de espera ficam próximos às travessias subterrâneas das outras três plataformas (duas delas previstas em uma segunda etapa, entretanto não executadas). Entre estes setores e ao centro da barra localizam-se as partes administrativas da rede ferroviária, enquanto no terço sudoeste situam-se funções de apoio como depósito e espaço para bagagens. Entre os terminais está o

Setor Ferroviário Setor Exposiçōes W///. Setor Rodoviário

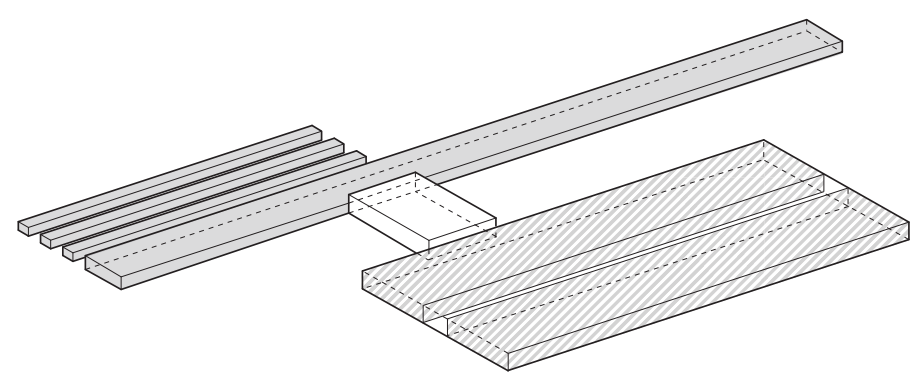

Figura 150 (acima): Circulação e cadeiras de espera em frente à plataforma de embarque do terminal rodoviário. Fonte: Acervo Rubens Meister

Figura 151 (abaixo): Plataformas de embarque do temrinal rodoviário. Fonte: Acervo Rubens Meister
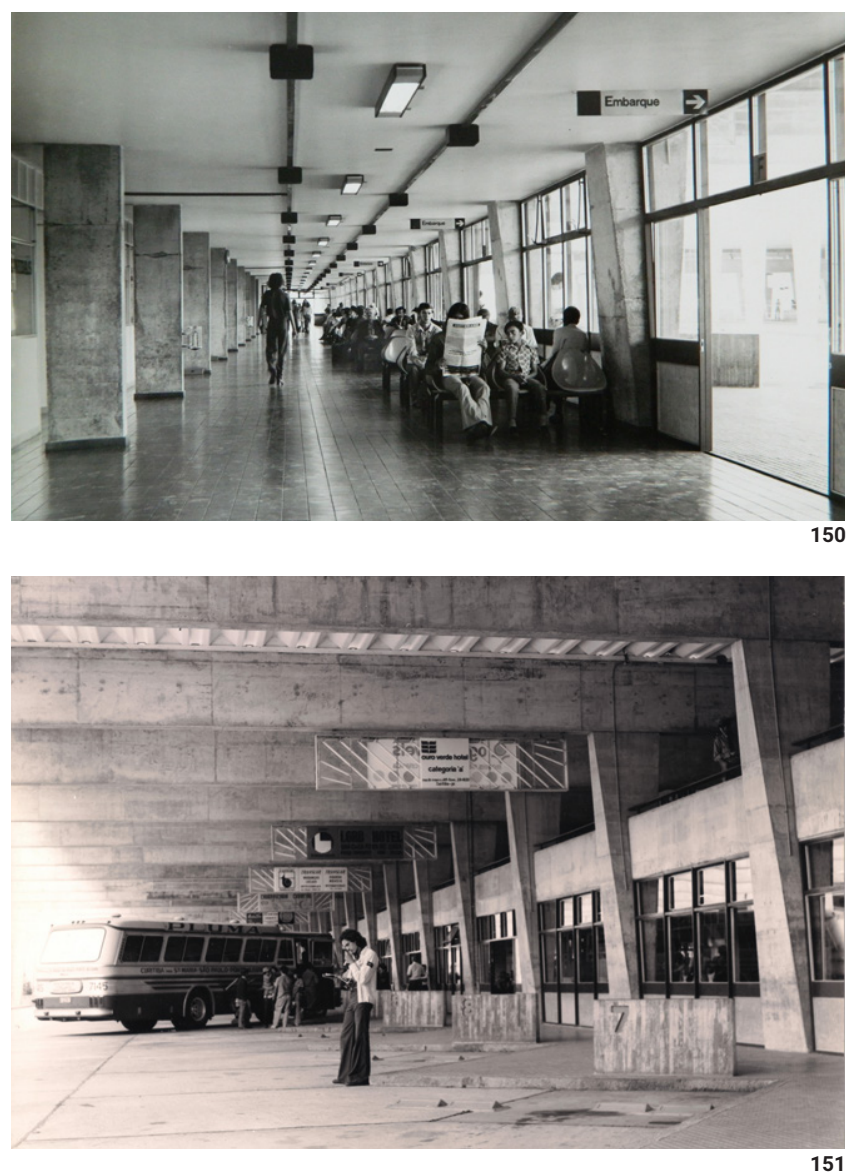
W//: Comércio

$\square$ Serviços de apoio

- Circulação/Travessias
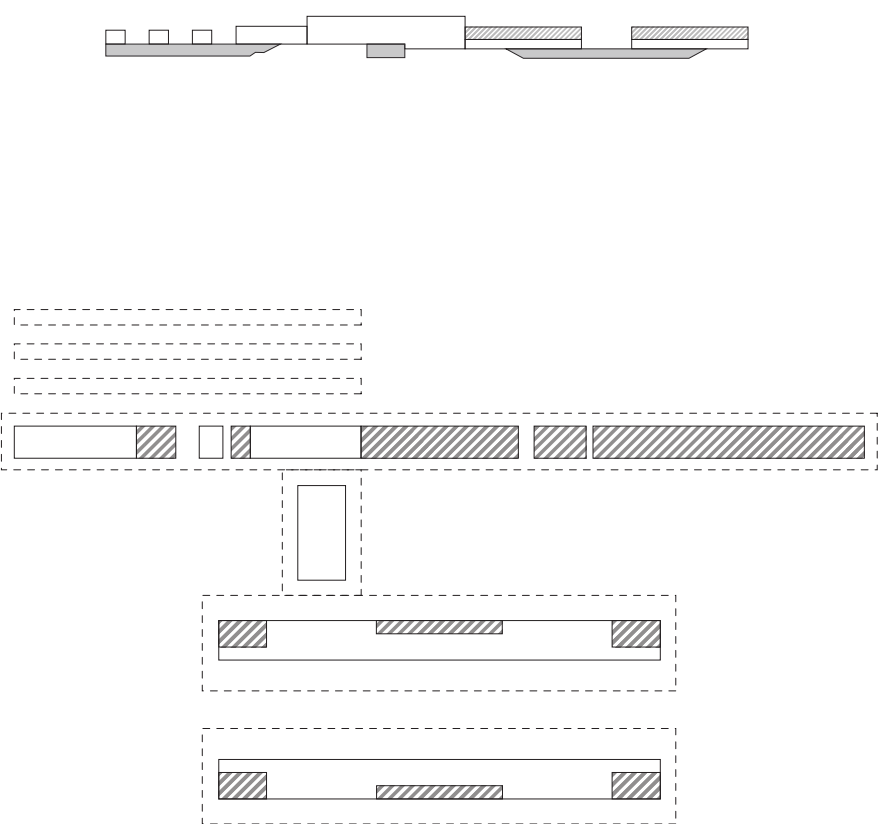

setor de exposições, dividido em subsolo, térreo e mezanino.

Em uma leitura do programa a partir do corte, pode-se dividir o subsolo como um setor de circulação/travessia, o térreo como serviços e apoio aos terminais e o primeiro pavimento como comércio

A permeabilidade proposta à edificação torna boa parte do espaço acessível ao público. Com exceção dos interiores ocupados por serviços, comércios, administração e alguns apoios, que podem aqui serem classificados como zona privada, o restante torna-se zona pública.
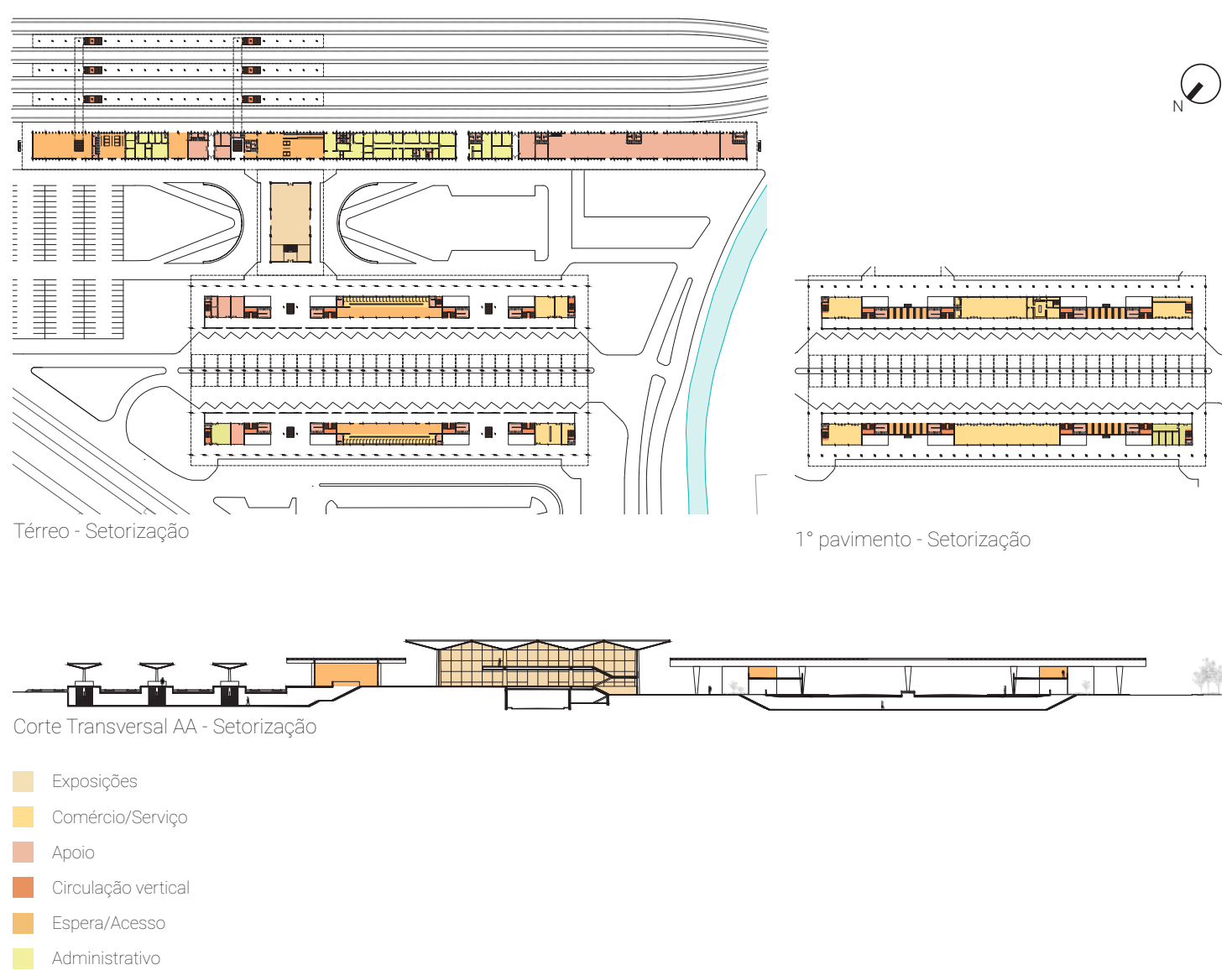
$1^{A}$

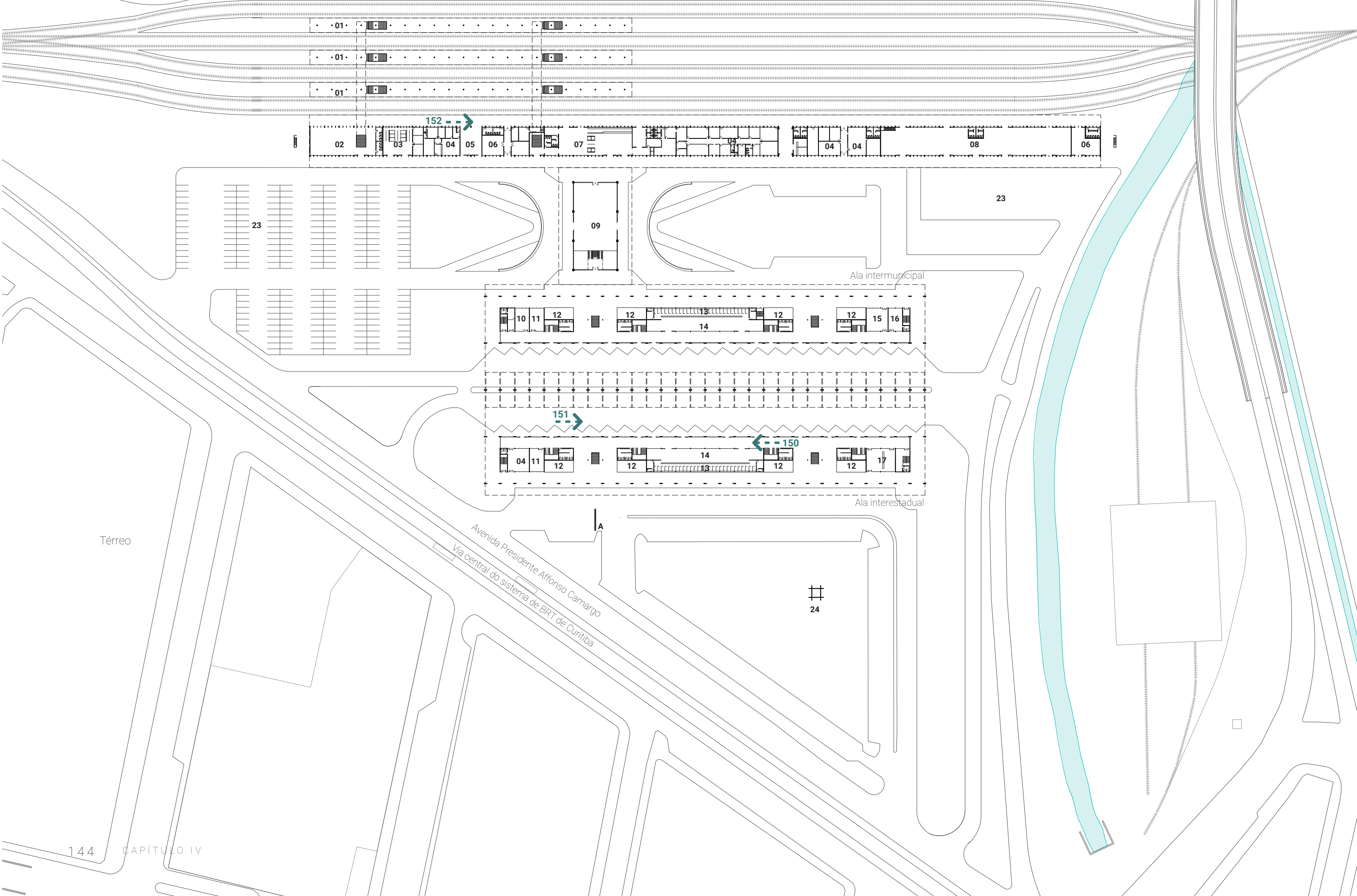



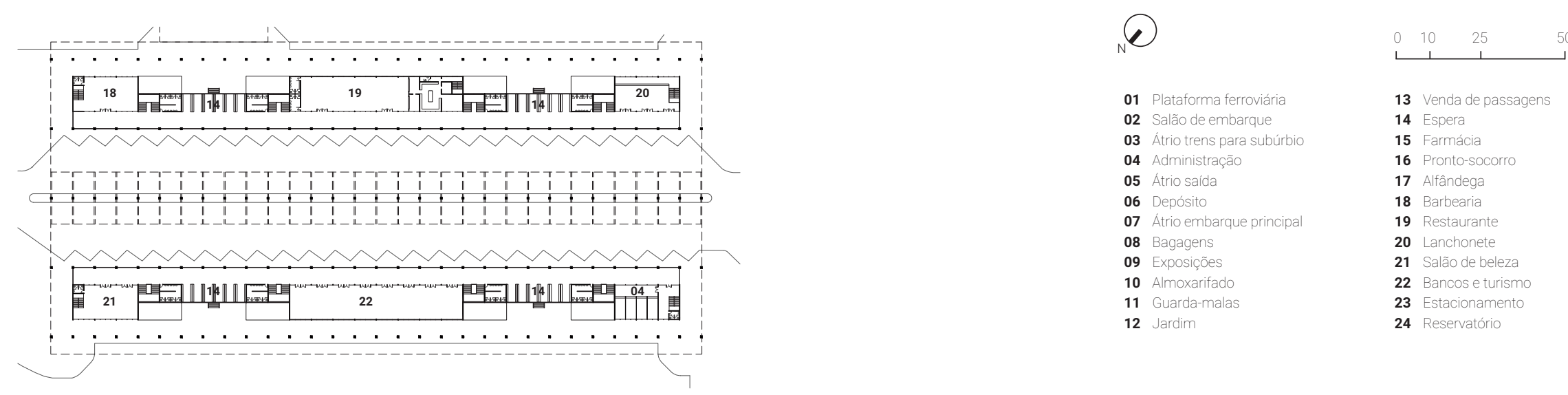

$1^{\circ}$ pavimento

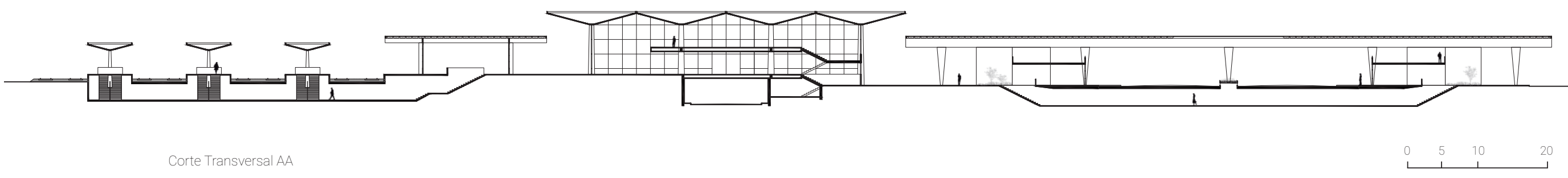




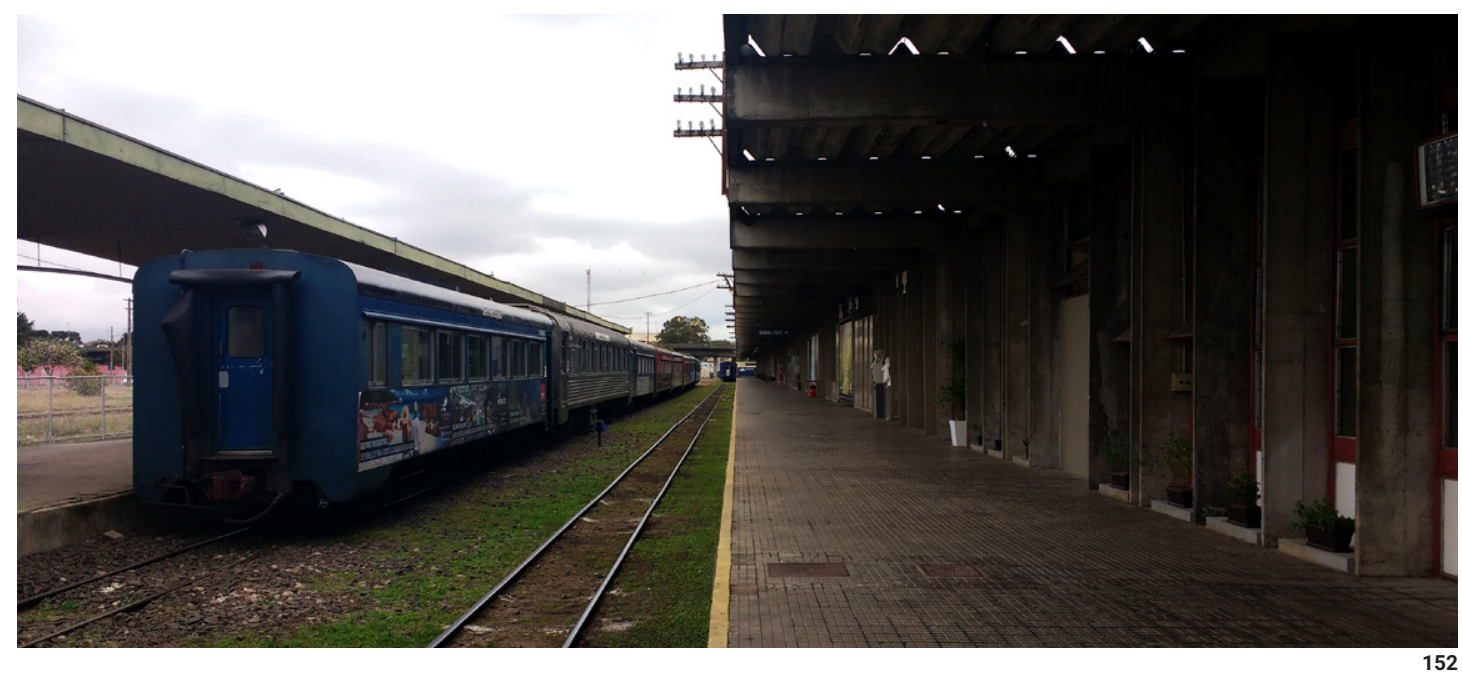

\section{Circulações e percursos internos}

As circulações verticais são distribuídas de forma equilibrada ao longo do programa, diminuindo os percursos horizontais dos usuários ${ }^{27}$. Assumindo uma chegada ao edifício através de automóvel, do acesso às plataformas de embarque ou salas de espera, a circulação é clara e eficaz. A ordenação dos elementos e usos junto às circulações verticais do terminal rodoviário criam um padrão "escada-banheiro-escada-banheiro-escada" nos finais do primeiro e terceiro quarto da barra, sendo que as duas escadas da extremidade são de acesso ao pavimento superior e a central, de travessia entre os blocos. As escadas das pontas estão vinculadas aos usos internos da edificação.

A pé ou a partir do transporte público, o acesso à ala intermunicipal e ao bloco intermediário e ferroviário está basicamente vinculado à passagem em um primeiro momento pela ala interestadual. O bloco intermediário de exposições faz a ponte de pedestres entre os terminais sendo que abaixo deste há uma passagem subterrânea de veículos que conecta à porção oeste

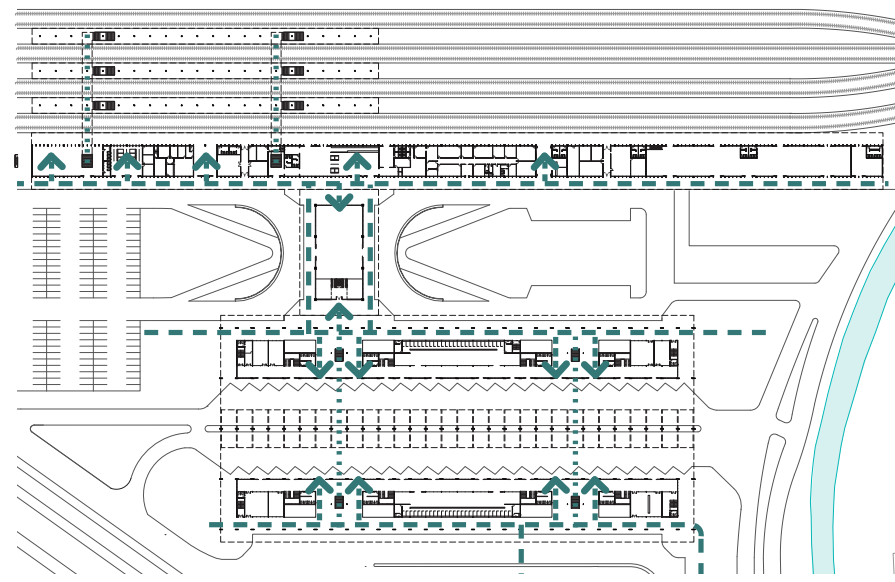

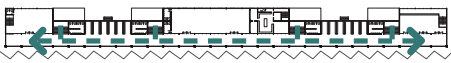

$$
\begin{aligned}
& \text { Dimphimin }
\end{aligned}
$$

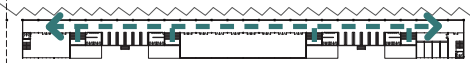


das duas estações. Neste caso, a distribuição é, ao contrário do Teatro Guaíra e Paço Municipal, desigual e não simétrico, ou seja, a travessia entre terminais não é centralizada ou de distância equivalente aos acessos.

Sobre os demais percursos que não estão vinculados às travessias ou circulações verticais pode-se observar que estes são essencialmente perimetrais aos usos internos.

\section{Relação entre espaços internos e externos}

São as projeções, ou beirais, do complexo que definem os espaços de transição nos três grandes setores. Delimitam os espaços de maneira convidativa e generosa principalmente nas perimetrais das duas alas rodoviárias, onde funcionam mais como uma circulação abrigada, tendo em vista os apoios externos da estrutura da cobertura.

O pé-direito baixo do pavimento superior, as grandes aberturas e a grande projeção da cobertura criam uma relação visual direta e interessante com o piso inferior e com os bolsões de vegetação pensados além da via de abastecimento do lado externo dos blocos. O bloco intermediário, quando não orientado às diferentes estações, também possui seus planos translúcidos voltados aos bolsões verdes em meio às vias internas. No caso do bloco ferroviário há um meio termo entre pátios de estacionamentos e massa arbóreas. Na porção central do bloco rodoviário a relação fica permeada entre pórticos que, estando abaixo, vê-se o céu e ao longo da perspectiva, deixa-se de enxergá-lo. Ao final, nas duas pontas, estas estruturas enquadram a massa vegetal entre vias de um lado e a composição verde do Rio Belém de outro.

A fruição entre usos é predominante neste projeto, desde a escala do complexo até os setores comerciais que possuem abertura, tanto para a circulação em frente à rodoviária quanto para o espaço de espera. Da chegada, pode-se ter uma considerável visão das plataformas de ambos os lados. A partir das salas de espera e comércios no $1^{\circ}$ pavimento há um domínio visual dos embarques e desembarques das alas interestaduais e intermunicipais, bem como dos acessos do lado oposto. pelo autor

Figura 153 (abaixo): Imagem mostrando a relação entre o espaço interno superior e externo inferior. Fonte: Acervo do autor.
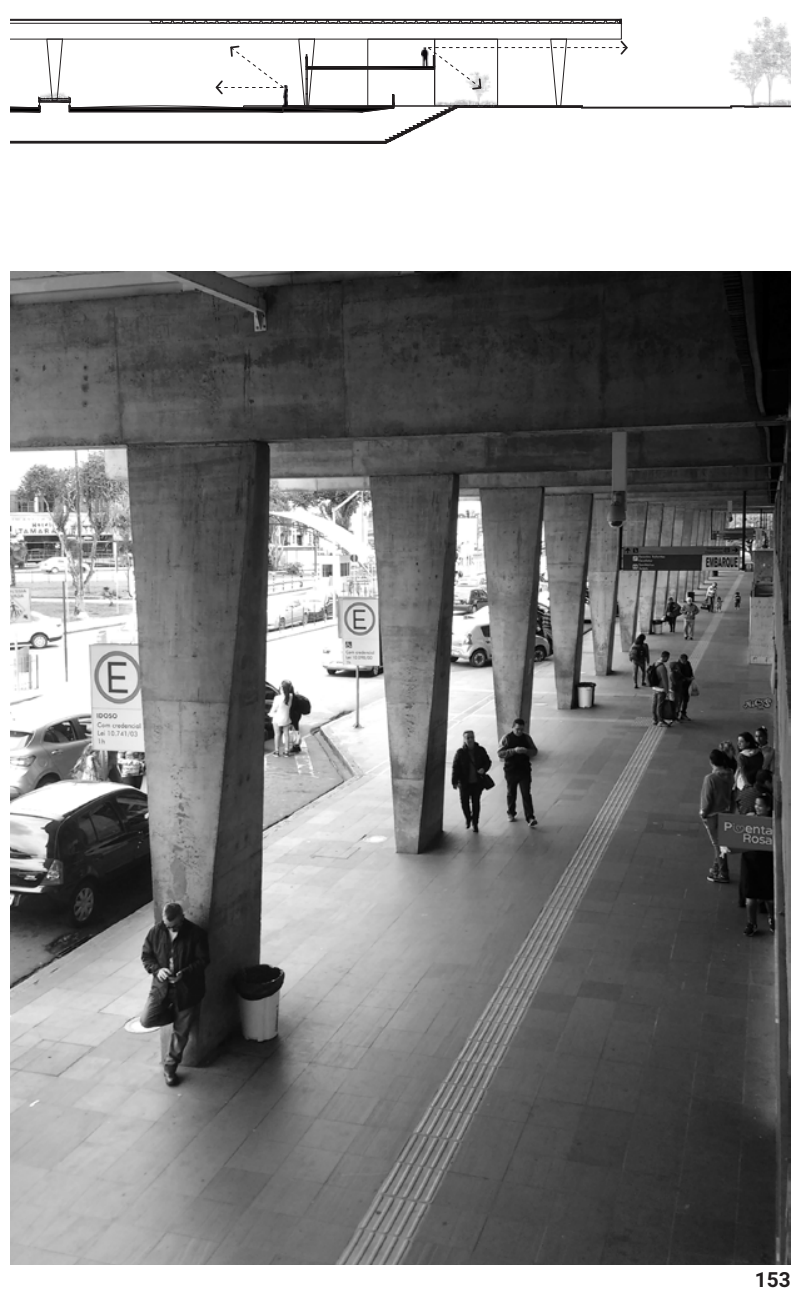

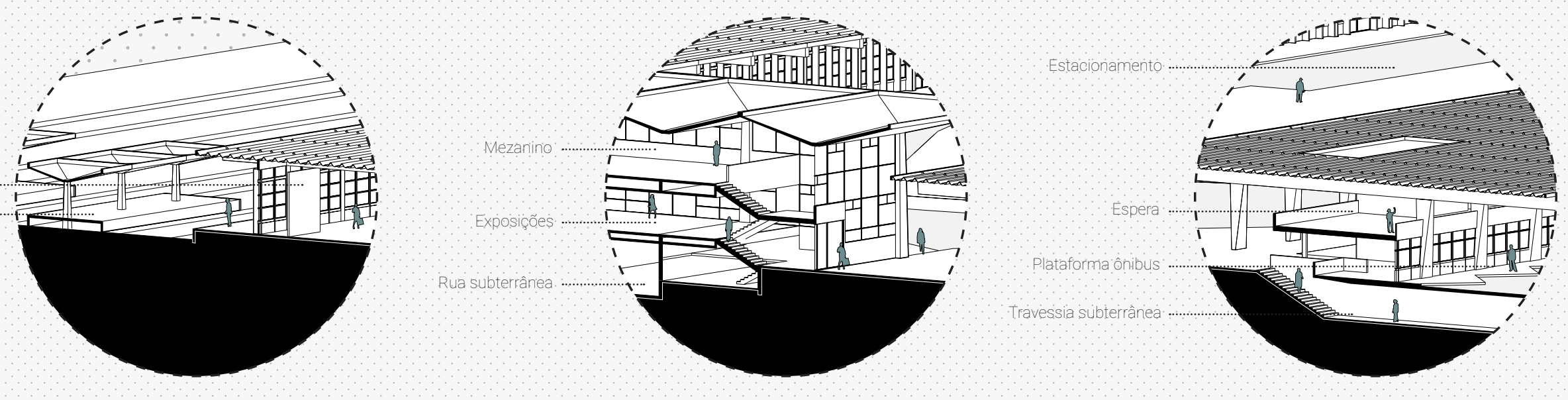

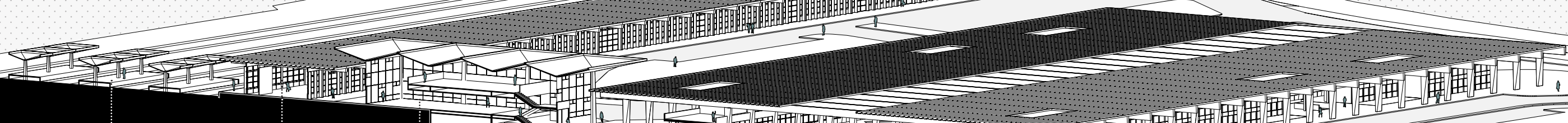



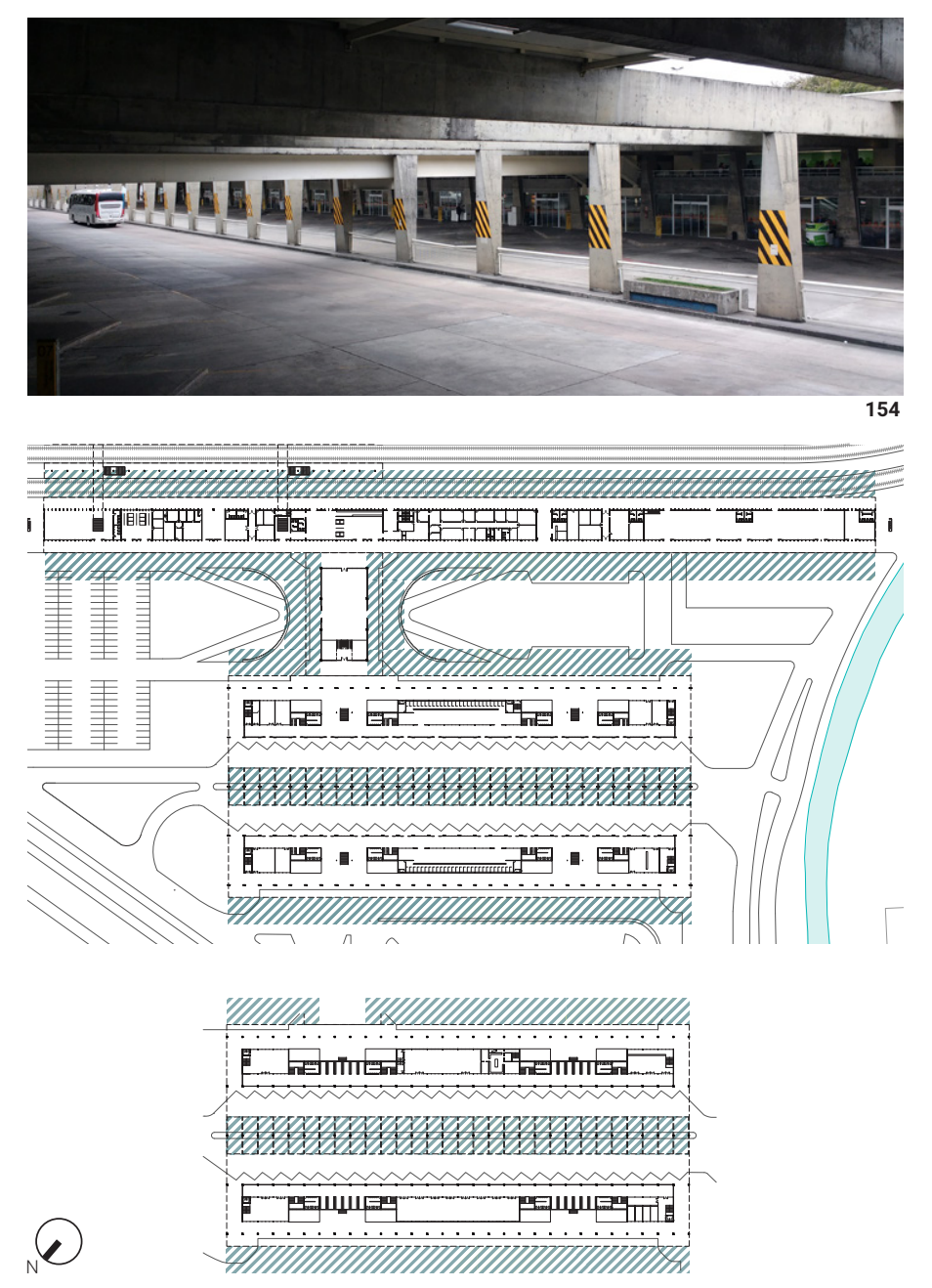

Figura 154 (acima): lluminação entre as plataformas. Fonte: Acervo do autor.

Abaixo: Iluminação nos dois pavimentos Fonte: Desenho desenvolvido pelo autor.

Figura 155 (na página seguinte): A luz no vão central. Fonte: Acervo do autor

\section{Iluminação natural}

A partir do projeto para a Rodoviária de Joinville (1968) - uma espécie de protótipo do que veio a ser projetado para Curitiba um ano depois - se observa um novo cuidado de Meister na contemplação da iluminação natural nos espaços, nas texturas e nos detalhes. Logo, os materiais e o desenho da estrutura são tratados aqui com especial importância. Houve uma reutilização daqueles mesmos preceitos utilizados em Joinville aqui em maior escala. 0 espelhamento em duas alas equivalentes do terminal rodoviário (intermunicipal e interestadual) gerou espacialidades que potencializam estes efeitos através de uma espécie de átrio central.

Os volumes dos projetos anteriores deram lugar aos anteparos. Beirais, projeções e pórticos funcionam como moderadores da luz natural e tomam formas variadas conforme o sol circula pelas horas do dia e pelos dias do ano. Neste sentido, o mais expressivo dos grandes setores é o terminal rodoviário.

Na definição das aberturas superiores, existem certas perspectivas que acabaram recebendo uma atenção especial do engenheiro-arquiteto. Meister, de forma simples e funcional mas muito sensível, concebeu um vão central do setor rodoviário guiado pelo desenho da sua estrutura e pela composição dos pórticos que receberiam iluminação direta (figura 154). O contraste entre a plataforma de embarque e a parte de circulação dos ônibus cria uma espacialidade rica e dotada de clareza (figura 155), sendo que esta ruptura central acaba funcionando como uma grande luminária. O pilar intermediário, banhado pela luz superior entre pórticos, é percebido de maneira diferente dos pilares periféricos, que recebem uma luz lateral. As vigas, quando não cobertas pelas telhas calhetão, apresentam-se em sua essência na continuidade do vão e têm sua forma - em secção "V" - valorizada pela luz. Já na parte perimetral dos blocos, o recuo nos núcleos de circulação vertical e banheiros abriga um jardim dotado de uma abertura zenital que ilumina estes ambientes nos dois pavimentos. 


\subsection{MODULAÇÃO, ESTRUTURA E EXPRESSÃO PLÁSTICA}

Abaixo: o módulo no espaço e as relações entre as medidas horizontais e verticais. A malha possui 1,60 × 1,28 metros. Fonte: Desenho desenvolvido pelo autor.
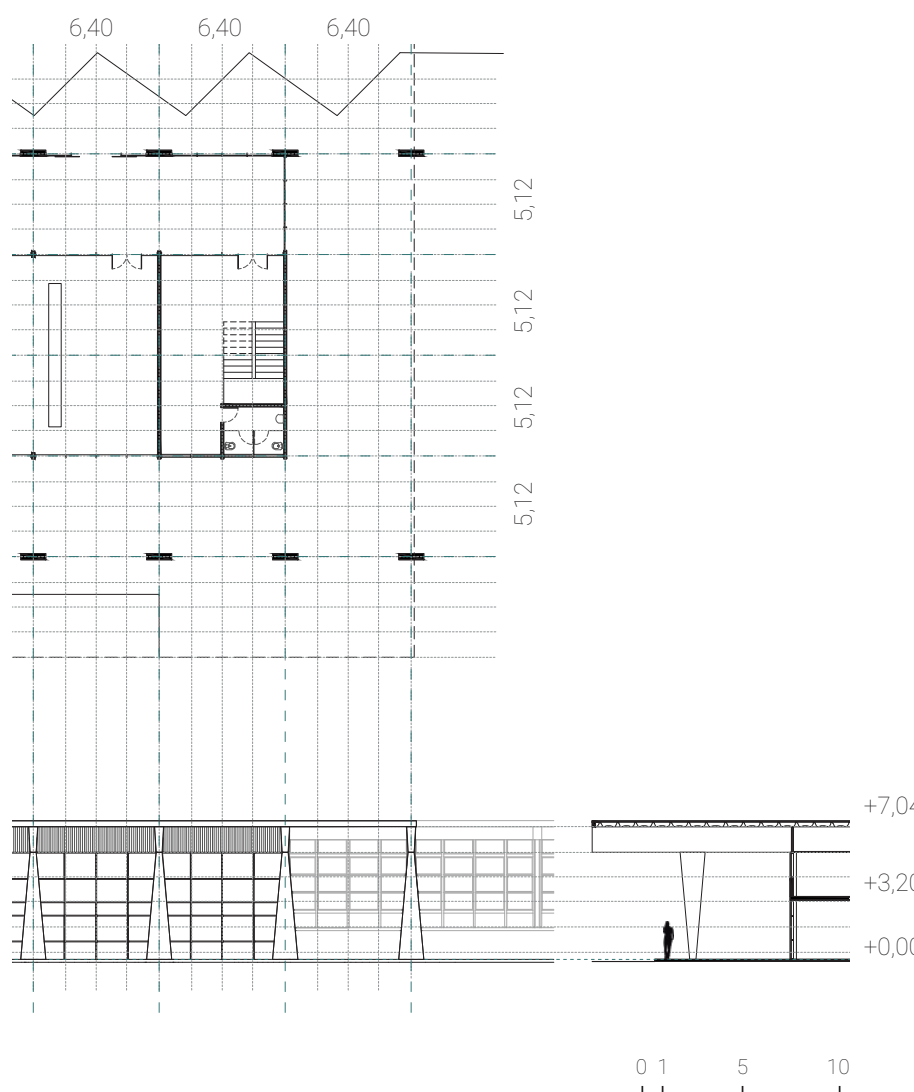

\section{Organização espacial}

Em uma construção essencialmente em concreto armado, mais uma vez Rubens Meister trabalha com o rigor do módulo estrutural derivado da medida inicial de 16 centímetros que organiza todo o projeto. As alvenarias, assim como a altura do degrau, possuem a dimensão inicial, logo o piso da escada possui 32 centímetros.

Os pilares da rodoviária tem secção inicial e final de 32 × 128 centímetros enquanto os menores possuem 16 × 32 centímetros. A distância do módulo estrutural entre cada um dos cinco pilares do pórtico, no sentido transversal à barra, é de 20,48 metros com uma projeção de viga de 5,12 metros do centro do pilar. O módulo entre os pórticos é de 6,40 metros, totalizando 31 deles. Abrigado na trama estrutural, as salas fechadas distanciam-se de 5,12 metros das extremas de cada bloco, mantendo o mesmo módulo longitudinalmente, no entanto a distância de 10,24 metros define a largura entre os dois pilares menores junto às esquadrias e vedações Os recuos dos banheiros e escadas ficam centralizados a 5,12 metros de cada ponta.

o bloco de exposições organiza-se sob uma malha modular de 4 pilares distanciados de 12,80 metros no comprimento por 2 pilares com distância de 19,20 metros na largura e beiral de 6,40 metros do eixo do módulo. O programa é determinado pelos fechamentos em esquadrias que estão alinhados sobre o módulo e entre os pilares.

O terminal ferroviário possui em seu comprimento 55 pilares distanciados de 6,40 metros e 2 pilares separados por 12,80 metros e beiral de 5,12 metros a partir do eixo do pilar. Os três elementos verticais em concreto, entre módulos, distanciam-se de 1,60 metros conformando quatro planos verticais de esquadrias ao longo de boa parte da barra. Ao longo do comprimento, as divisões internas do programa seguem rigorosamente estes elementos externos e acabam alinhadas à linha de pilares. Já nas plataformas dos trens, os 22 pilares em linha única estão espaçados modularmente em 6,40 metros com projeção da laje de 3,20 metros. 


\section{Composição geométrica e desenho da estrutura}

A sucessão de pórticos e o refinamento das peças que o compõem (pilar e viga) conferem protagonismo do desenho estrutural à estética do bloco rodoviário. O sistema utilizado de forma diferente no bloco de exposições possui igual importância na sua expressão plástica. Nesse tema, talvez a solução mais comedida das três seja a atribuída ao bloco ferroviário, mesmo que análoga à aplicada ao bloco rodoviário.

O desenho do pilar do setor rodoviário é o elemento de maior relevância e que mais confere identidade ao projeto do complexo rodoferroviário: um pilar de secção 32 por 128 centímetros na base e 128 por 32 centímetros no topo. A conexão entre estes pontos ao longo dos 5,44 metros de altura, conferem plasticidade única ao apoio, uma sensação de torção da peça buscando receber o assentamento da viga a partir da mesma largura. A viga calha possui uma secção que reduz sua largura ao tocar os 32 centímetros de largura da base superior do pilar. Todos os pórticos conferem ao bloco rodoviário um comprimento de 192,32 metros e 92,16 metros de largura. Estes mesmos recursos foram utilizados um ano antes no projeto para a Rodoviária de Joinville (1968).

O mesmo sistema de pórtico, simplificado em dois apoios, foi adotado ao longo dos 346,04 metros de comprimento do bloco ferroviário. Os pilares, em secção "U”, possuem pontas variáveis e as vigas calhas, formato retangular. Este sistema proporciona uma largura de 23,04 metros à lâmina

A solução estrutural adotada no setor de exposições consiste em pilares de secção quadrada e de dimensões variáveis, reduzindo-a conforme aproxima-se de uma laje plissada semelhante ao sistema utilizado no projeto para a Igreja Nossa Senhora da Luz de Clevelândia (1963). As coberturas das plataformas de embarque dos trens (figura 156) também possuem um sistema de laje plissada modular (CARVALHO, BATISTA, CHIESA, 2019, p.271-273), nesse caso em solução muito similar às paraboloides hiperbólicas presentes nas estações ferroviárias
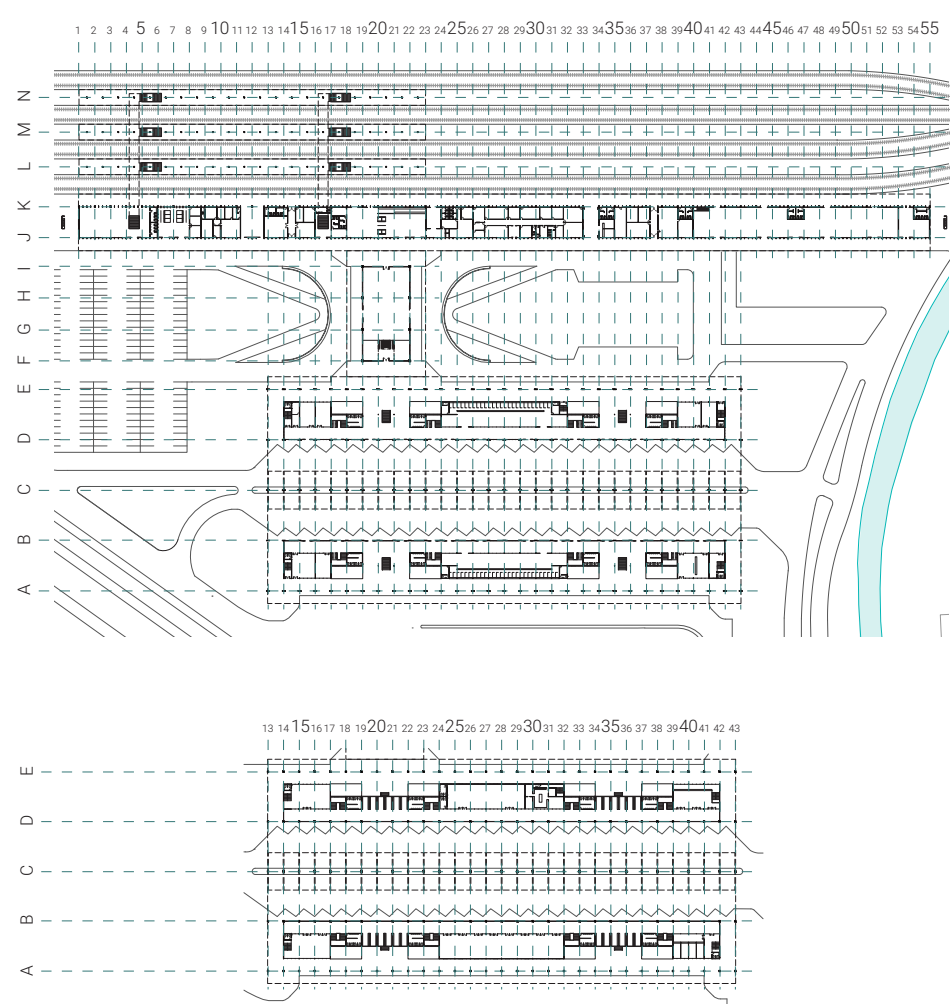

Acima: Eixos estruturais no térreo e primeiro pavimento respectivamente. Fonte: Desenho desenvolvido pelo autor 


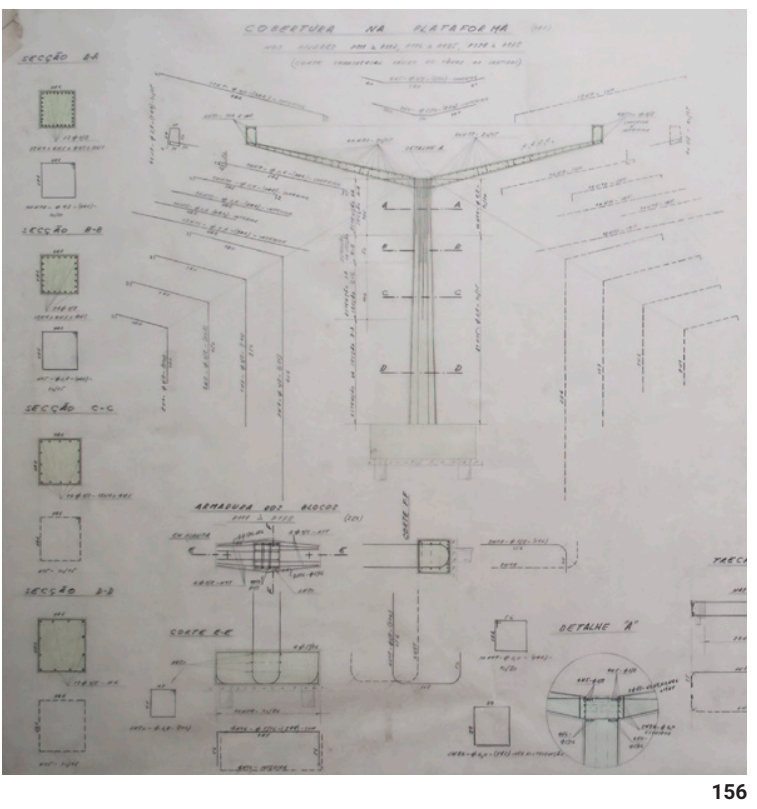

da Companhia Mogiana (1960) de Oswaldo Arthur Bratke. ${ }^{28}$

A disposição dos setores, além de serem fruto das condicionantes e de uma solução funcional de implantação e setorização, encontram-se justapostas em proporções harmônicas e que dão unidade ao conjunto. O bloco central e mais alto funciona como uma ponte entre as estações e rompe a organização do complexo como um discreto elemento vertical, sendo os seus beirais alinhados aos beirais das duas diferentes estações. A mescla dos dois blocos rodoviários em um confere um protagonismo a essa função voltada às vias principais de acesso enquanto o destacado comprimento da barra ferroviária acompanha paralelamente parte do trilho da linha pré-existente. Alinhadas com o limite da empena do bloco ferroviário à nordeste, no plano horizontal, as plataformas de embarque dos trens possuem comprimento que segue até o alinhamento oposto da cobertura do bloco intermediário.

28 Nota: Este detalhe foi comentado pelo professor Hugo Segawa na entrega da monografia para a disciplina AUH5854 - Arquitetura contemporânea Paulista. O projeto pode ser encontrado em: SEGAWA, Hugo, DOURADO, Guilheme M. Oswaldo Arthur Bratke arquiteto. São Paulo: ProEditores, 1997, p. 213-219
Figura 156 (nesta página acima): Detalhes construtivos da plataforma ferroviária. Fonte: Acervo Rubens Meister.

Nesta página (à direita): As proporções entre os blocos correspondentes aos setores do complexo. Fonte: Desenho desenvolvido pelo autor

Na página seguinte: A plasticidade das peças que compõem o sistema estrutural nos diferentes setores. Fonte: Desenho desenvolvido pelo autor
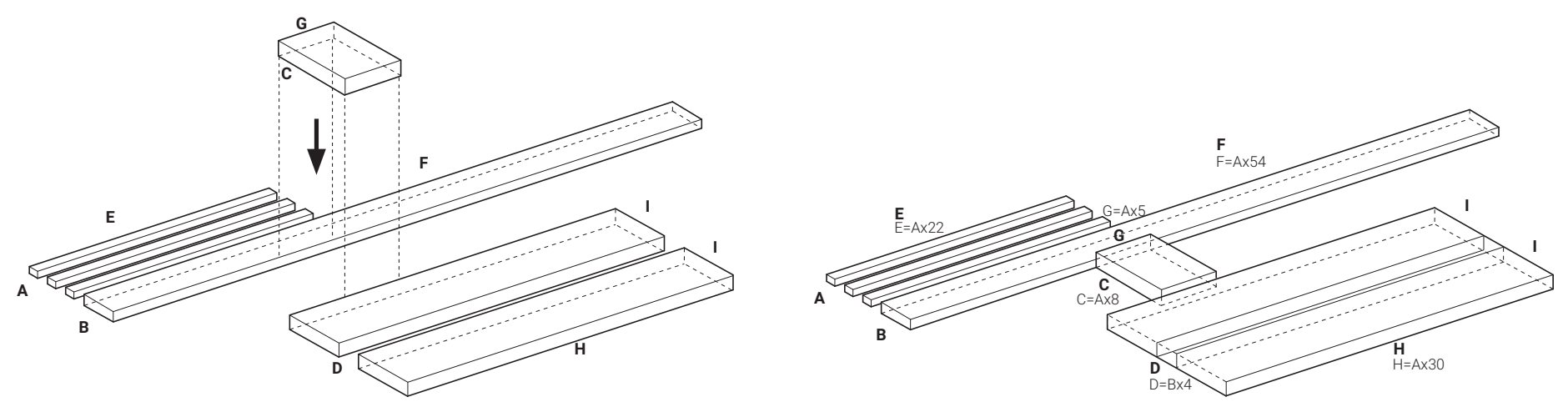


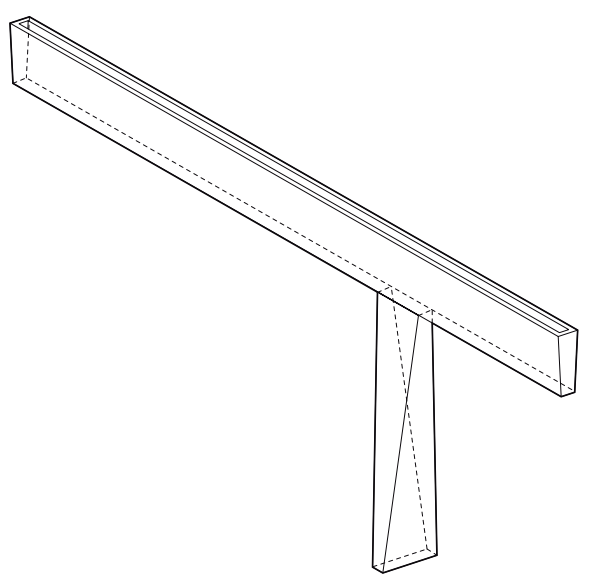

Setor Rodoviário

Setor de Exposições
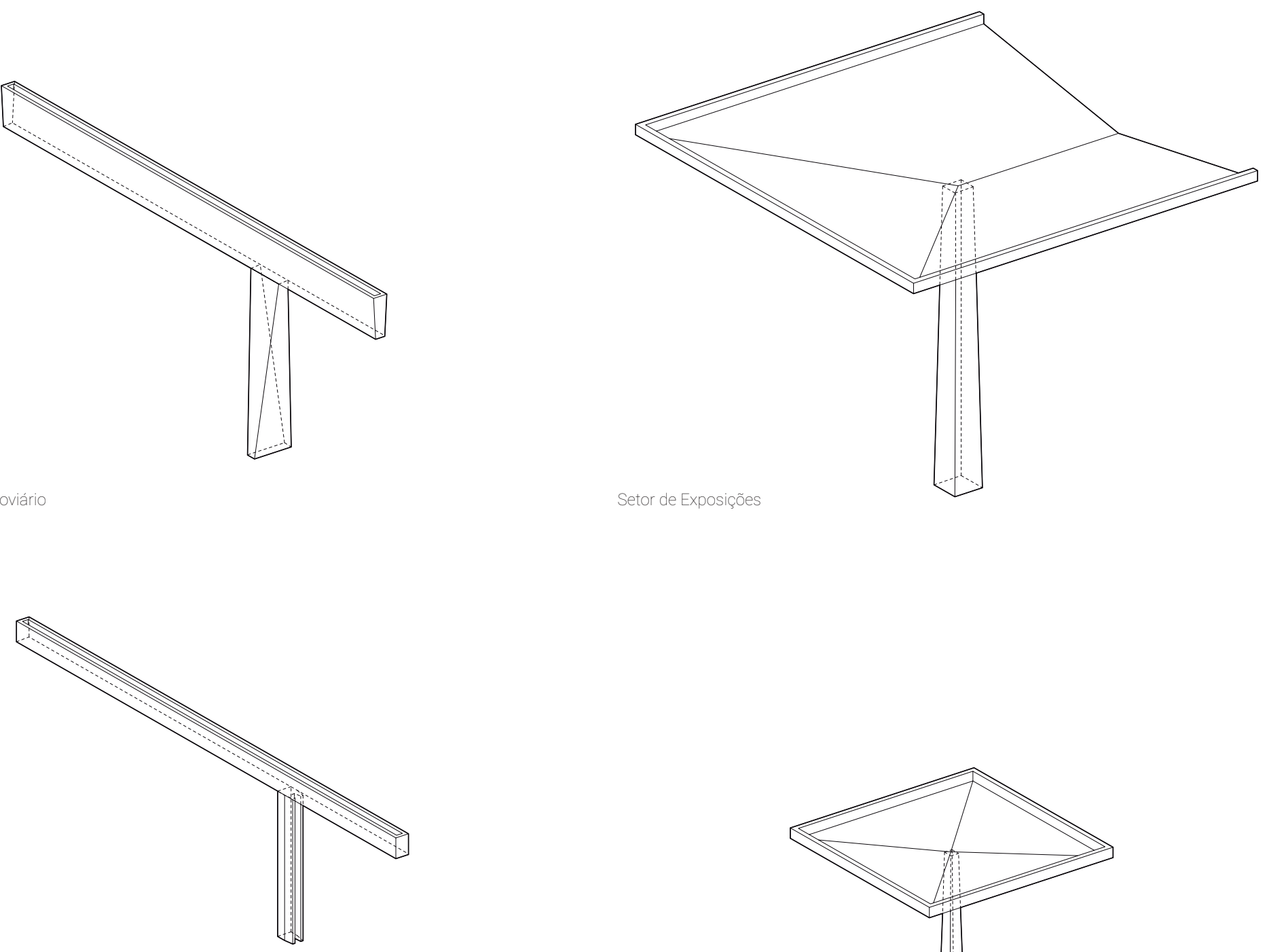

Setor Ferroviário

Plataforma Ferroviária

154

CAPITULO IV 
Figuras 157, 158, 159, 160 e 161: Da esquerda para a direita: a telha calhetão, o ripado em madeira sobre as esquadrias, a paginação dos tijolos maciços das empenas, o concreto aparente da estrutura e o piso pré-fabricado em concreto. Fonte: Acervo do autor.
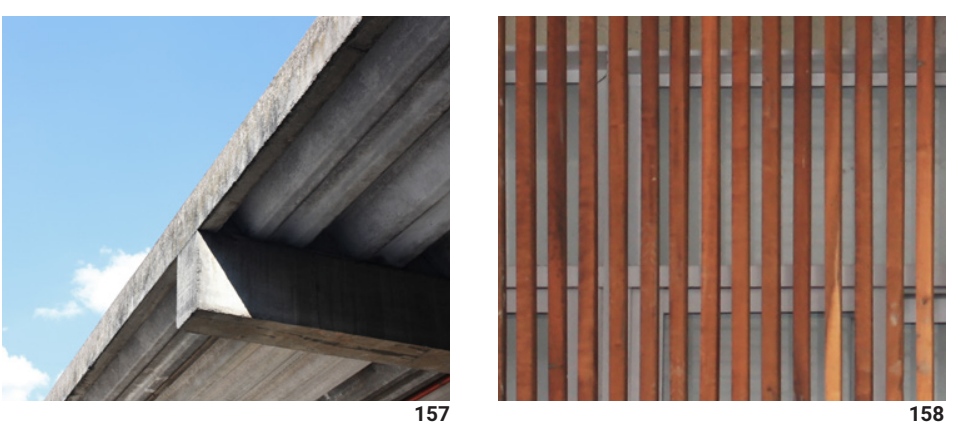

\section{Materialidade}

Os poucos materiais desta obra foram selecionados tendo em vista a alta resistência necessária para o constante uso público deste equipamento. Os mesmos são utilizados estrategicamente e com intenção de preservação de seu caráter original. A predominância, sem dúvida, é do concreto aparente em toda a estrutura do complexo. Contudo, aliado ao tijolo maciço situado nas paredes externas e à madeira de acabamento acima das esquadrias do primeiro pavimento, estabelece-se aqui diretrizes de composição que reverberaram na grande maioria dos projetos de Rubens Meister a partir dos anos 1970

Os pisos internos são em cerâmica escura enquanto nas plataformas foram aplicados pisos em concreto pré-fabricados. As esquadrias são todas em aço e pintadas em azul no setor rodoviário na parte frontal do ferroviário e em terracota no setor de exposições e na parte posterior do ferroviário. Os guarda corpos e corrimões também são em aço na cor azul bem como os peitoris abaixo dos caixilhos, enquanto as telhas, tipo calhetão, são em fibrocimento.

No interior e no exterior do edifício é inegável dizer que os materiais e texturas são instrumentos fundamentais na composição desta obra. Se por um lado as tonalidades neutras como o cinza dos concretos, pisos e vias aparentam dominar o ambiente, por outro elas são sutilmente quebradas pelos elementos de tonalidades quentes como a madeira e as alvenarias em tijolos maciços, pelas cores predominantemente azul das esquadrias e principalmente pelo verde natural constantemente enquadrado pelos pórticos.
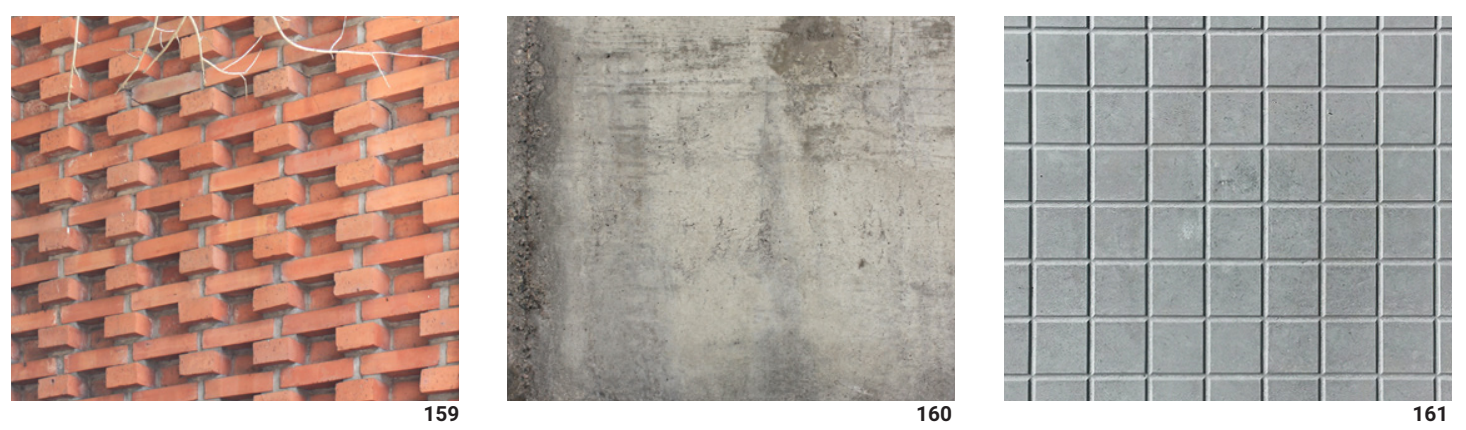

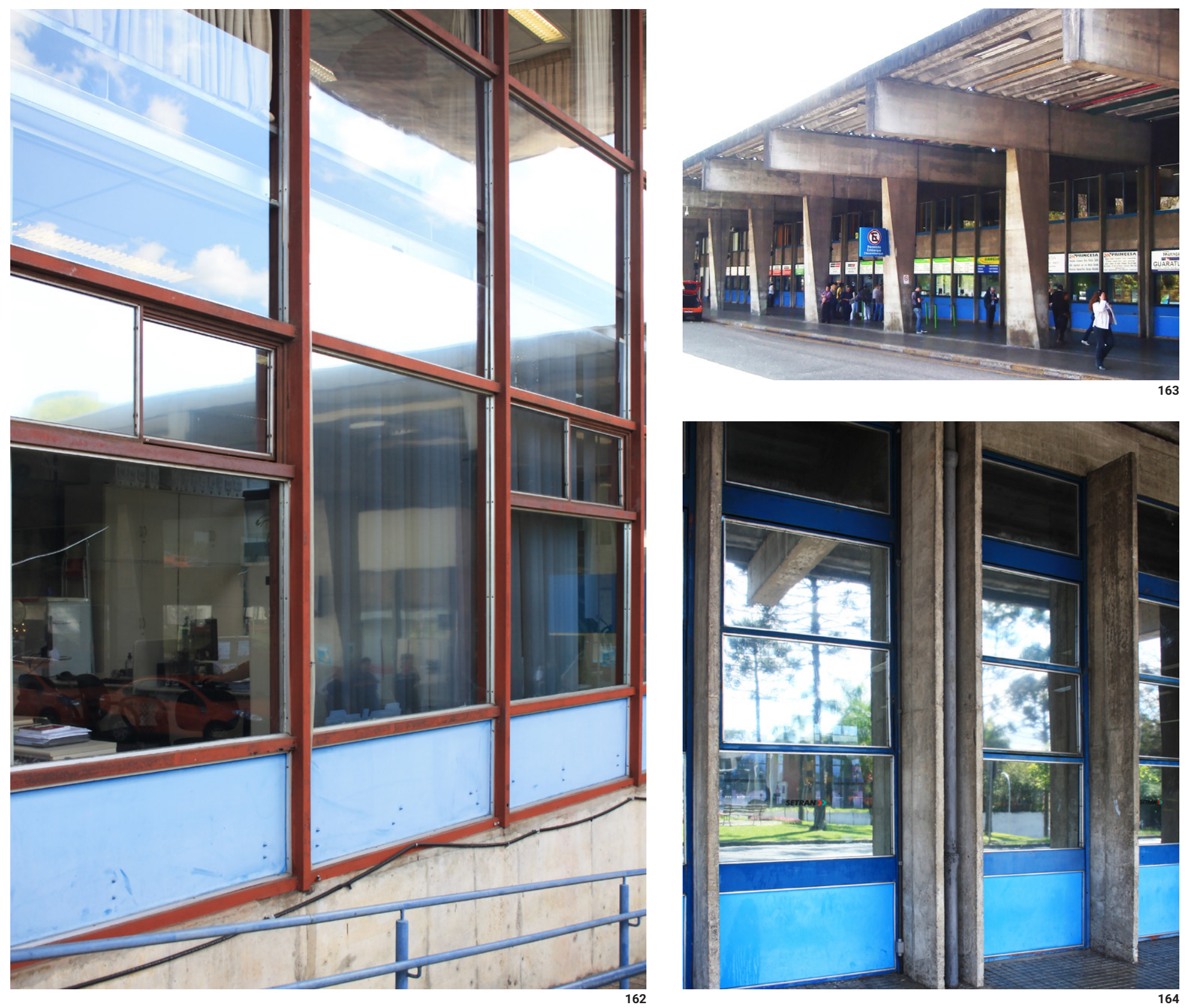

Figura 162 (à esquerda): Materialidade na fachada do setor de Exposições. Fonte:

Figura 163 (à direita e acima) : A aplicação dos materiais nas fachadas do Terminal Rodoviário antes da reforma. Fonte: Open Green Map. Disponivel em: <http:/ opengreenmap.org/sites/defaul/files/ user_upload/rodoviaria2.jpg>. Acesso em. 03.out.2019.

Figura 164 (à direita e abaixo). Os materiais na fachada do Terminal Ferroviário 


\section{Conclusões}

Figura 165: A rodoviária de Joinville na década de 1970. Fonte: Página "Fotos Antigas de Joinville". Fonte: Fotos antigas de Joinville. Atualmente indisponivel.

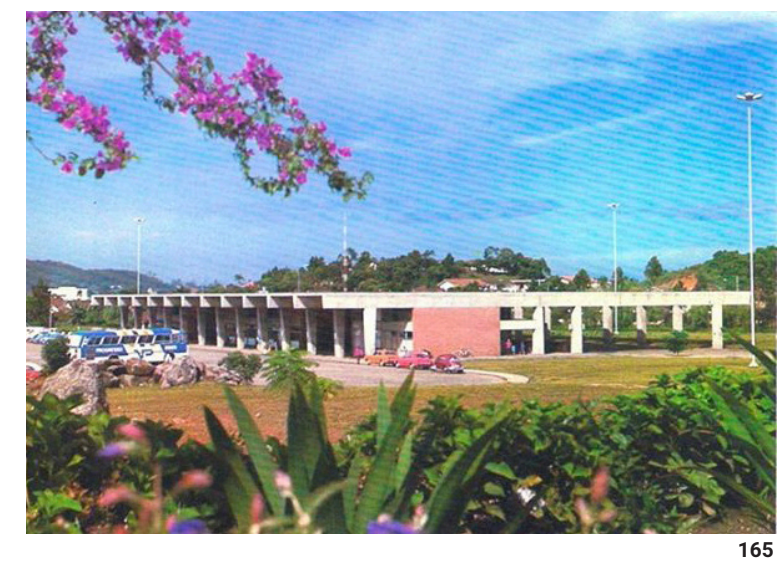

O prédio da Rodoferroviária é, além de um grande marco na cidade de Curitiba, peça fundamental na história da arquitetura moderna do Paraná. O reconhecimento deste trabalho levou Rubens Meister a ser chamado para desenvolver outros projetos no interior do estado: rodoviárias de Paranaguá (1972), Toledo (1976), Foz do Iguaçu (1978) e Apucarana (1981).

O projeto é fruto da experimentação estrutural presente nos dois projetos de Joinville Pavilhão da Expoville (1967) e na Rodoviária (1968) (figura 165). No Pavilhão, a trama dos tijolos de vedação e o desenho da estrutura externa aparenta ter sido o embrião do que Meister veio a desenhar na Rodoviária de Joinville, enquanto os pilares internos foram moldes para os apoios do projeto da Agência do Banco Bamerindus (1969) em Curitiba. Ainda, e junto destas demais obras, o complexo da capital paranaense parece confirmar algumas inflexões na carreira de Rubens Meister e ao mesmo tempo manter fielmente os pressupostos adotados desde o início.

Os beirais e as projeções configuram e definem bem os espaços de transição entre o interior e o exterior da mesma forma que já havia feito na antiga Rodoviária de Curitiba (1956). No entanto, a estrutura da Rodoferroviária confere enorme expressão plástica à obra como tectônica e composição. Sabiamente, mais uma vez Meister utiliza a estrutura como unificação do conjunto. A continuação da viga dos pórticos unindo as duas barras do setor rodoviário confere unidade ao projeto, de modo semelhante à solução do Palácio 29 de Março (1960)

A aparente simplificação dos elementos de projeto deriva de um uso mais "pesado" inerente a um equipamento urbano de grande escala e voltado a veículos. É sabido, contudo, que a síntese das soluções empregadas nesta obra gerou um artefato genuíno e digno de ser um dos portais de acesso à cidade de Curitiba. Vale ressaltar que este é um momento em que Rubens Meister passa a adotar soluções mais simples e "diretas" em seus trabalhos demonstrando que, durante o projeto para a Rodoferroviária, também há uma transição no seu modo de pensar arquitetura. 


\section{Conclusões gerais}

Durante os quase cinquenta anos em que manteve suas atividades profissionais, Rubens Meister conduziu uma obra que, embora discreta no panorama moderno brasileiro, teve grande destaque no espaço urbano de cidades do interior do Paraná e Santa Catarina e, sobretudo, de Curitiba. Os cuidados com a inserção dos edifícios no contexto das cidades, a clareza dos espaços, a rigorosa construção baseada em módulos, a expressão plástica resultante das soluções construtivas e, principalmente, a resiliência com que levou estes trabalhos ao longo dos anos o colocam em uma posição de notoriedade na arquitetura moderna paranaense. Estas são características que, por mais que tenham sido tratadas com pesos diferentes ao longo da sua trajetória profissional, estiveram sempre vinculadas ao seu fazer arquitetura.

Sua carreira teve contribuição única nos encaminhamentos da cultura arquitetônica no Paraná e adquiriu grande relevância também pela amplitude de atividades que desenvolveu além do projeto arquitetônico: desenho de peças de mobiliário, urbanismo, docência, fundação do curso de arquitetura da UFPR e presidência do Instituto de Engenheiros do Paraná.

A presente pesquisa consistiu em estabelecer métodos de análise que consigam sintetizar, de modo claro, alguns dos elementos que nortearam a produção deste engenheiro-arquiteto que, apesar de sediado em escritórios de modestas dimensões, acumulou um grande número de obras ao longo de cinco décadas.

Acerca das leituras realizadas nos capítulos que compõem o trabalho, muitas das análises não necessariamente objetivaram um método comparativo entre os três projetos, sabendose que estes tratam de temáticas distintas. Há, entretanto, algumas abordagens que nos permitem decifrar alguns dos princípios projetuais presentes na arquitetura de Rubens Meister. A escolha dos temas e do método gráfico permitiu compreender um processo de pensamento que, expresso através de seus projetos, acompanharam a formação e desenvolvimento da sua 
carreira.

As obras definidas em recorte compreendem diferentes perspectivas do engenheiroarquiteto. No Teatro Guaíra, Rubens Meister evoca um saber distante, construído a partir das suas próprias leituras e estudos das referências consolidadas. Este conhecimento advindo da Europa teve, no Brasil, o seu expoente inicial em terras cariocas que, apesar de mais próximas a Curitiba, não eram de fácil acesso para Meister. As materializações deste saber estampavam, no entanto, seus livros e revistas. Hugo Segawa articula o teatro a estas influências ao afirmar que "no Paraná, o engenheiro Rubens Meister, inequivocamente um pioneiro do moderno paranaense, ao projetar o Teatro Guaíra na capital do Estado, o faz com algumas referências formais à arquitetura do Rio de Janeiro." (SEGAWA, 1998, p.142-143).

Este conhecimento evoluía e se expandia conforme o teatro se materializava. Junto a outros projetos e obras que se desenvolviam ao longo da década de 1950, maturou um saber prático concomitante ao amadurecimento e consolidação de alguns critérios, os quais recaíram sobre os projetos que se sucederam e chegaram à sua essência no Palácio 29 de Março. "Depois da experiência 'corbusiana' do Teatro Guaíra, Meister foi contagiado pelo classicismo de Mies van der Rohe, na vertente do racionalismo metodológico-didático, segundo descrição de Giulio Carlo Argan". (GNOATO, 2009, p.117).

Menos de dez anos depois, a partir do final da década de 1960, o retorno aos pressupostos orgânicos de Wright circundou suas obras. Do uso dos materiais e valorização do desenho dos pilares no projeto para a Estação Rodoferroviária de Curitiba, Meister assimilou de forma estrutural os ensinamentos do arquiteto norte-americano nos projetos seguintes.

Sua trajetória foi longa, quase 50 anos que cruzaram períodos turbulentos de crises e revisionismos no âmbito arquitetônico. Mudanças não seriam grandes surpresas. No entanto, há uma essência em questão que vai além das recorrências e paralelismos, um determinante comum: a razão construtiva. Nas suas palavras: 
"Chega um certo momento que você fica aborrecido com aquilo que vinha produzindo. Você não pode repetir sempre. Chega um momento que você tem que fazer algo diferente. Agora mesmo estou trabalhando no projeto de uma igreja, onde introduzi uma modulação

triangular para dar mais variedade à forma. Quem usou essa modulação triangular foi Frank Lloyd Wright, e o triângulo equilátero dá uma versatilidade muito grande de forma. Uma igreja facilita isso Não me preocupo se está moderno, se é velho ou não. Me preocupo em produzir algo que agrade. E o que nós possuímos para produzir

alguma coisa durável? É justamente os métodos construtivos

Materiais, métodos construtivos e tecnologia da construção. E, mesmo para a tecnologia, o profissional tem que estar preparado para se deparar com situações de aprendizado." (MEISTER in VIANNA et al., 1999, p. 17)

Os três projetos estudados no trabalho estão implantados em um quarteirão inteiro. Todavia, o cenário construído ao redor do Teatro Guaíra diferencia-se: foi implantado em um terreno antigo pertencente a um Clube de Tiro e de entorno já previamente consolidado na década de 1940. Apesar das desapropriações pertinentes aos demais projetos, a realidade dos seus entornos eram distintas. Terrenos que, mesmo próximo ao centro, estavam em locais de baixa densidade. O Palácio 29 de Março foi construído junto a um bairro de chácaras e em um antigo banhado, no qual estava sendo implantado o Centro Cívico no início da década de 1950. A Rodoferroviária encontrava-se no limite entre a cidade e o trem, possuindo a sul e sudeste, um bairro residencial e fabril no início da década de 1970. O uso desse equipamento condicionado pela posição do trilho do trem condicionou, de certa forma, a uma configuração de frentes e fundos bem definida, ao contrário dos outros dois projetos. 
A materialização do campo limítrofe é evidente no Teatro Guaíra e no Palácio 29 de Março, enquanto na Rodoferroviária a natureza abstrata sugere uma diferente abordagem à ideia de limite. Se a expressão plástica da "casca" confere identidade ao Teatro Guaíra, na Rodoferroviária essa ideia é transmitida à unidade do sistema estrutural. Apesar da ordenação modular e do uso adequado da estrutura no teatro, o desenho da peça estrutural não protagoniza a expressão plástica final, mas sim a forma gerada pela solução construtiva. Na Rodoferroviária acontece o contrário, o desenho da estrutura confere identidade e a forma corresponde a uma sucessão destes elementos. Pode-se dizer que o Palácio 29 de Março ocupa um meio-termo, a estrutura configura um sistema que se apresenta junto à uma geometria pura e definida e, juntas, resultam na estética do artefato

Na composição das formas, o Teatro Guaíra foi lido como um complexo dividido em três partes, assim como a Estação Rodoferroviária. À primeira vista, o que chama atenção é que estão ambos os projetos divididos em blocos. No caso do Guaíra, Meister se utiliza da sobreposição destes. Na Rodoferroviária, os blocos estão soltos entre si, setorizados e claros. Apesar do "conflito formal", a expressão plástica, decorrente do programa, no teatro é didática. Já a obra do Palácio 29 de Março apresenta-se como um todo único em que a complexidade é diminuta. Marca a gênese deste projeto um manifesto puro a uma arquitetura moderna e racional. A geometria está presente desde a concepção inicial e revela-se elemento fundamental na composição do desenho.

A materialidade, em sua essência, ganha força na Rodoferroviária principalmente no uso do concreto aparente. No Teatro Guaíra é utilizada como um invólucro das formas geradas, alternando entre estrutura e vedação em determinados momentos. O sistema estrutural tem maior peso na definição da expressão plástica do Palácio 29 de Março que é todo comunicado em concreto escuro e preenchido, entre os módulos, por planos de esquadria e alvenaria ora branca ora revestida por placas de mármore travertino.

A articulação do espaço interno funciona de maneira semelhante na Rodoferroviária e no 
Palácio 29 de Março: no plano horizontal e vertical, estes percursos encontram-se equilibrados com o programa e escadas e, vistos em planta, possuem um eixo de simetria (deslocado para um dos dois principais percursos na Rodoferroviária). A relação com os principais acessos é direta nesses projetos, que possuem dois vínculos retilíneos e não centrais. No Teatro Guaíra, apesar da assimetria do conjunto, os dois auditórios principais (grande auditório e médio) possuem um eixo central de circulação ao serem analisados isoladamente: parte-se do centro e divide-se o fluxo em duas partes equivalentes que conduzem às circulações verticais.

A questão da iluminação natural é tratada de maneira cuidadosa com uma pequena concessão correspondente ao miolo central do pavimento térreo do Palácio 29 de Março. A problemática da orientação solar demonstra não ter sido valorizada da mesma forma. Em cada um dos projetos, as aberturas e planos transparentes são similares entre si nas diferentes fachadas, com ausência de elementos que realizem o controle da incidência do sol. Os beirais na Rodoferroviária confıguram uma exceção aqui.

Meister, a partir da década de 1970, retornou às tipologias variadas em suas implantações, ante a geometria pura que o consagrou a partir de meados dos anos 1950. Se no início da sua carreira, além da questão programática, a forma era definida pela estrutura e pelos avanços plásticos que o concreto possibilitava, na etapa final a mesma estava mais submetida aos pressupostos orgânicos de Wright. Nos extremos opostos da linha temporal de sua carreira, a função e o programa buscam legibilidade na volumetria externa de seus projetos, com ênfase na plasticidade do concreto no início e na força da materialidade ao final. A utilização do módulo triangular e a forma hexagonal se perpetuaram nos seus trabalhos a partir da década de 1970. Há, entretanto, casos como o do Palácio 29 de Março (1960) em que em seus primeiros estudos (que ainda contavam com a torre anexa) uma grande marquise em frente a edificação composta por uma estrutura hexagonal. Isso mostra que, apesar de mudanças na sua arquitetura, a essência de alguns temas estruturantes mantiveram-se intocadas sob diferentes formas ao longo da carreira profissional. 
Mesmo dotada de resiliência, sua obra, em certo momento, é marcada por um momento de ruptura. Compreender estas diferentes etapas requer também uma busca nas influências que guiavam o pensamento projetual de um engenheiro de formação, que aprendeu arquitetura sem uma fonte intelectual primária de ensino projetual. Meister, no entanto, conseguiu desenvolver o seu modo de pensar projeto a partir de critérios de ordem visual claros e de forma consistente. Compreendia as bases históricas e fundamentos da modernidade, sem reduzi-los a um conceito fechado e dotado de um conjunto de características. Sua não formação propriamente em arquitetura nunca o impediu de estudá-la rigorosamente e se atualizar no que estava acontecendo pelo Brasil e pelo mundo.

"Sempre li muito. Projetei o Guaíra sem ter saído do Brasil. (...) Uma revista boa era a argentina Nuestra Arquitectura, que mostrava discussões de Le Corbusier, apresentando La Cité Radieuse, debates de Frank Lloyd Wright, de Mies van der Rohe, e da época de 20, quando nasceu o movimento Bauhaus, o Funcionalismo e o Racionalismo, que acredito que sejam os mais importantes

movimentos deste século." (MEISTER, 1995 apud SUTIL; GNOATO, 2005, p.22)

Esta frase não apenas atesta os estudos à distância de Meister, mas também confirma as principais referências levantadas nesta pesquisa. Apesar da influência destes arquitetos citados por Meister se mostrarem de diferentes formas nas três obras, cada um esteve presente nos momentos da sua carreira com pesos diferentes.

Sem a pretensão de classificar a trajetória do engenheiro-arquiteto em fases, recorre-se a essa mesma busca apenas salientar algumas soluções que refletem as circunstâncias do seu raciocínio em determinada época. Os diferentes horizontes estéticos perseguidos nos três 
projetos denotam variadas formas de pensar arquitetura que, de alguma forma, caracterizaram a obra de Meister. Alguns autores como GNOATO (2005), CARVALHO, BATISTA e CHIESA (2019) escrevem sobre dois momentos na trajetória profissional do arquiteto: um primeiro momento que vai de 1948 a 1969 e está relacionado ao racionalismo construtivo europeu de Le Corbusier e Mies van der Rohe e outro que vai de 1970 até seus últimos projetos no final dos anos 1990 e está relacionado ao organicismo norte-americano de Frank Lloyd Wright (CARVALHO; BATISTA; CHIESA, 2019, p. 35). É válido destacar que os três projetos aqui estudados, dotados de diferenças e paralelismos entre si, estão vinculados a um mesmo momento, a partir dos levantamentos destes autores.

Ao longo dos anos de atividade profissional, o estudo e dedicação de Meister Ihe conferiram grande conhecimento - sob olhar atento - de uma arquitetura que navega sobre um plano comum sem, tendo em vista a aplicada compreensão sobre a realidade da construção no Brasil, necessariamente lhe conferir falta de identidade. Mesmo contando com algumas variações aqui destacadas, é uma obra que mostra um método de trabalho, um projeto claro, didático e que expõe recursos técnicos. Seus projetos tornaram-se referências da sua época, assimilaram e contribuíram com o desenvolvimento tecnológico sem se desvencilhar de preceitos básicos da arquitetura.

Por fim, a presente pesquisa pretende ser uma contribuição para a compreensão da ampla produção de Rubens Meister e da qualidade e importância das suas manifestações que vieram a transformar o espaço construído da cidade de Curitiba e a se tornar referências nos estudos de arquitetura. 


\section{Bibliografia}

\section{Livros}

ÁBALOS, Iñaki. A Boa Vida: Visita guiada às casas da modernidade. São Paulo: Gustavo Gili Brasil, 2003

ANELLI, Renato. Rino Levi Arquitetura e Cidade. São Paulo: Romano Guerra, 2001.

ARGAN, Giulio Carlo. Arte Moderna - do iluminismo aos movimentos contemporâneos. São Paulo: Companhia das Letras, 1992

ATTOE, Wayne. La crítica arquitectónica como disciplina. México D.F., Limusa, 1982 (versão em espanhol de: ATTOE, Wayne. Architectural and critical imagination. Chicester: John Wuley \& Sons, 1978).

BAXANDALL, Michael. Padrão de Intenção: a explicação histórica dos quadros. São Paulo: Cia das Letras, 2006

BRASIL, Luciana Tombi. David Libeskind: Ensaio sobre residências unifamiliares. São Paulo: Romano Guerra/Edusp, 2007

BERRIEL, Andréa; SUZUKI, Juliana Harumi. Memória do Arquiteto: Pioneiros da Arquitetura e do Urbanismo no Paraná. Curitiba: Instituto de Arquitetos do Paraná, 2012.

CARDOSO, Jaime Antônio; WESTPHALEN, Cecília. Atlas histórico do Paraná. Curitiba: Livraria do Chain, 1986. CARTER, Peter. Mies van der Rohe at work. Londres: Phaidon Press, 1999.

CARVALHO, Deborah Agulham; BATISTA, Fábio Domingos; CHIESA, Paulo. Rubens Meister: Projeto e Obra. Curitiba: Grifo, 2019. 
CASTRO, Elizabeth Amorim de. Edifícios públicos de Curitiba: Ecletismo e modernismo na arquitetura oficial. Curitiba: Edição do autor, 2011.

DUDEQUE, Irã José Taborda. Espirais de Madeira. Uma História da Arquitetura de Curitiba. São Paulo: Editora Studio Nobel, 2001.

DUDEQUE, Irã José Taborda. Nenhum dia sem uma linha. Uma história do Urbanismo em Curitiba. São Paulo: Editora Studio Nobel, 2010.

GIMENEZ, Luis Espallargas; GUERRA, Abílio. Eduardo de Almeida. São Paulo, Romano Guerra, 2006.

GNOATO, L. Salvador P.. Arquitetura do movimento moderno em Curitiba. Curitiba: Travessa dos Editores, 2009.

GNOATO, L. Salvador P.. Kirschgässner: um modernista solitário. Curitiba: Museu Oscar Niemeyer, 2017.

MACEDO, Guilherme de; BATISTA, Fábio Domingos; TAKEUCHI, Washington. Prédios de Curitiba. Curitiba: Lona Arquitetos, 2017.

MONEO, Rafael. Inquietação teórica e estratégia projetual. São Paulo: Cosac \& Naify, 2008.

MONTANER, Josep Maria. Arquitetura e crítica. Barcelona: Gustavo Gili, 2007.

NESBITT, Kate (Org.). Uma Nova Agenda para a Arquitetura: Antologia Teórica. São Paulo: Cosac Naify, 2006.

NGO, Dung. Louis I. Kahn: Conversas com estudantes. Barcelona: Gustavo Gili, 2002.

NISSEN, Erich; NISSEN, Loire; SEKULA, Waltraud; LEARDINI, Jul; BEATRICE, Claudionor. Teatro Guaíra: nasce um ícone. Curitiba: Edição do autor, 2016.

PFEIFFER, Helen. Helio Piñón - Ideias e Formas. São Paulo: Hedra, 2010. 
PIÑÓN, Helio. Mirada Intensivas. Barcelona: Edicións UPC, 2000.

PIÑÓN, Helio. Mario Roberto Álvarez. Barcelona: Edicións UPC, 2002.

PIÑÓN, Helio. El Proyecto como (Re)Construcción. Barcelona: Edicións UPC, 2005.

PIÑÓN, Helio. Teoria do Projeto. Porto Alegre: Livraria do Arquiteto, 2006.

PISANI, Daniele. Paulo Mendes da Rocha Obra Completa. São Paulo: GG Brasil, 2013

PUENTE, Moisés. Conversas com Mies van der Rohe. Barcelona: Gustavo Gili, SL, 2006.

ROWE, Colin. The Mathematics of the Ideal Villa and Other Essays. Cambridge/London: Massachusetts Institute of Technology, 1976.

SEGAWA, Hugo. Arquiteturas no Brasil 1900-1990. São Paulo: EDUSP, 1998.

SEGAWA, Hugo; DOURADO, Guilherme Mazza. Oswaldo Arthur Bratke. São Paulo, PW, 2012.

SILVA, Helena Ayoub. Abrahão Sanovicz arquiteto. São Paulo: Romano Guerra/Instituto Lina Bo e P. M. Bardi, 2017.

SUTIL, Marcelo. O espelho e a miragem: ecletismo, moradia e modernidade na Curitiba do início do século 20. Curitiba: Travessa dos Editores, 1996

SUTIL, Marcelo; GNOATO, L. Salvador P.. Rubens Meister: Vida e Arquitetura. Curitiba: Travessa dos Editores, 2005.

WACHOWICZ, Ruy Christovam. História do Paraná. Curitiba: Imprensa Oficial do Paraná, 2002.

XAVIER, Alberto. Arquitetura moderna em Curitiba. São Paulo: PINI, 1985.

ZEVI, Bruno. Saber ver a arquitetura. Capítulo 3 - A representação do espaço. São Paulo: Martins Fontes, 1996.

ZUMTHOR, Peter. Pensar Arquitectura. Barcelona: Gustavo Gili, 2009. 


\section{Teses e dissertações}

FERRONI, Eduardo Rocha. Aproximações sobre a obra de Salvador Candia, Dissertação de Mestrado - Faculdade de Arquitetura, Universidade de São Paulo, São Paulo, 2008.

FOLTAN, Roberto Tourinho. A arquitetura de Vilanova Artigas no Paraná: os projetos em Curitiba, Ponta Grossa e Caiobá (1942-1978), Dissertação de Mestrado - Universidade Federal do Rio Grande do Sul, Porto Alegre, 2014

GNOATO, L. Salvador P.. Introdução ao ideário modernista na arquitetura de Curitiba. Dissertação de Mestrado - Faculdade de Arquitetura, Universidade de São Paulo, São Paulo, 1997.

IWAMIZU, Cesar Shundi. Eduardo de Almeida. Reflexões sobre estratégias de projeto e ensino, Tese de Doutorado - Faculdade de Arquitetura, Universidade de São Paulo, São Paulo, 2015.

MATERA, Sergio. Carlos Milan: Um estudo sobre a produção em arquitetura, Dissertação de Mestrado - Faculdade de Arquitetura, Universidade de São Paulo, São Paulo, 2005.

OBA, Leonardo Tossiaki. Marcos urbanos e a construção da cidade: a identidade de Curitiba, Tese de Doutorado - Faculdade de Arquitetura, Universidade de São Paulo, São Paulo, 1999.

ROSENBERG, Juan Pablo. A construção do território. Abstração e natureza nas obras de Luiz Barrágan, Álvaro Siza e Tadao Ando, Dissertação de Mestrado - Faculdade de Arquitetura, Universidade de São Paulo, São Paulo, 2016.

SOARES, Luciano Margotto. A arquitetura de Álvaro Siza: três estudos de caso, Dissertação de Mestrado - Faculdade de Arquitetura, Universidade de São Paulo, São Paulo, 2002.

\section{Artigos em periódicos e entrevistas}

AZEVEDO, F. C. de. O Teatro Oficial do Estado. Gazeta do Povo, Curitiba, 16 de janeiro, 1949 
BIGGS, Michael; Büchler, Daniela. Pesquisa acadêmica em áreas de prática projetual. Revista da Pós n. 26, p 168 - 183. São Paulo, FAUUSP, 2009.

BIGGS, Michael; Büchler, Daniela. Oito critérios para a pesquisa acadêmica em áreas de prática projetual. Revista da Pós n. 27, p 136 - 152. São Paulo, FAUUSP, 2010.

GNOATO, Salvador. Vanguarda Paranaense. Entrevista concedida a Haifa Y. Sabbag. AU n. 151, outubro 2006.

JÚNIOR, Key Imaguire. Breve introdução à arquitetura paranaense. Projeto, n. 89, julho 1986, p. 33-39.

LEMOS, Carlos. A verdadeira origem do movimento moderno da arquitetura brasileira. Folha de São Paulo, 3 de setembro de 1972.

MEISTER, Rubens. Pioneiro da Arquitetura Moderna no Paraná. Entrevista concedida a Ruth Verde Zein. Projeto, n. 89, julho 1986, p. 40-47.

MEISTER, Rubens. Rubens Meister. Entrevista concedida a Fabiano Vianna, Letícia Cristina Kaniak, Vivian Borges dos Reis, Humberto Mezzadri e Irã Dudeque. Revista Lócus, n. 003, novembro 1999, p. 6-25.

PIÑÓN, Helio. O estilinho internacional. Revista da Pós n. 27, p 66 - 85. São Paulo, FAUUSP, 2010.

SEGAWA, Hugo. Outro programa de passeio, agora em Curitiba. Projeto, n. 89, julho 1986, p. 31-

32.

ZEIN, Ruth Verde. Arquitetos no Paraná, algumas diferenças nas mesmas estórias. Projeto, n. 89, julho 1986, p. 28-30. 


\section{Sites}

BUBNIAK, Tatiana. A presença de Mies van der Rohe. Disponível em: http://www.gazetadopovo. com.br/imoveis/a-presenca-de-mies-van-der-rohe-bkbai82r2712m8u8pj4f8bo7i. Acesso em: 09 de julho de 2018.

COLLARES, Julio. Exoesqueletos primogênitos: Le Corbusier e o Palácio dos Soviets. Disponível em: https://www.ufrgs.br/propar/domino/2005_01/txt05_2005_01.htm. Acesso em: 26 de dezembro de 2018.

GNOATO, L. Salvador P.. Entrevista: Vanguarda Paranaense. Disponível em: http://au.pini.com.br/ arquitetura-urbanismo/151/artigo33676-3.aspx. Acesso em: 8 de agosto de 2018.

GNOATO, L. Salvador P.. Rubens Meister - Racionalismo e Rigor Construtivo. Disponível em: http:// au.pini.com.br/arquitetura-urbanismo/160/artigo55258-5.aspx. Acesso em: 10 de dezembro de 2018.

GNOATO, L. Salvador P.. Curitiba, cidade do amanhã: 40 anos depois. Disponível em: http://www. vitruvius.com.br/revistas/read/arquitextos/06.072/351. Acesso em: 20 de julho de 2018.

VELOSO, Maisa; ELALI, Gleice. Há lugar para o projeto de arquitetura nos estudos de pós graduação? Vitruvius: Arquitextos 020.07, ano 02, Janeiro de 2002. Disponível em: http://www. vitruvius.com.br/revistas/read/arquitextos/02.020/817. Acesso em: 20 de novembro de 2018.

MAHFUZ, Edson da Cunha. Observações sobre o formalismo de Helio Píñón. Disponível em: https://www.vitruvius.com.br/revistas/read/arquitextos/08.089/196. Acesso em: 17 de dezembro de 2019.

Secretaria da Comunicação Social e Cultura - Patrimônio Cultural do Estado do Paraná. Disponível em: http://www.patrimoniocultural.pr.gov.br. Acesso em: 12 de dezembro de .2019. 

Índice de obras construídas (1943-1990) 


\section{Estrutura base do currículo oficial de Rubens Meister}

105 projetos

Fonte: Currículo oficial presente no acervo Rubens Meister

\section{OBRAS PÚBLICAS FEDERAIS}

1.1 Capela da Reitoria da UFPR

Área: $100 \mathrm{~m}^{2}$

Local: Curitiba - PR

Cliente: Ministério da Educação e Cultura

Ano: 1953

\subsection{Auditório da Reitoria da UFPR}

Área: sem informação

Capacidade: 704 espectadores

Local: Curitiba - PR

Cliente: Ministério da Educação e Cultura

Ano: 1955

\subsection{Centro Politécnico da UFPR}

Área: Plano - $500.000 \mathrm{~m}^{2}$ | Edificações - $40.000 \mathrm{~m}^{2}$

Local: Curitiba - PR

Cliente: Ministério da Educação e Cultura

Ano: 1956

\subsection{Escola Profissional do Senai}

Area: Plano - $6.000 \mathrm{~m}^{2}$

Local: Ponta Grossa - PR

Cliente: Serviço Nacional de Aprendizagem Industrial

Ano: 1959

1.5 Edifício Lydio Paulo Bettega (SESI/FIEP)

Área: $8.000 \mathrm{~m}^{2}$

Local: Curitiba - PR

Cliente: Serviço Social da Indústria

Ano: 1962

1.6 Auditório, Centro de Abastecimento e Ginásio do SESI (FIEP)

Área: $5.000 \mathrm{~m}^{2}$

Local: Curitiba - PR

Cliente: Serviço Social da Indústria

Ano: 1962

\subsection{Centro de Treinamento do Magistério do Paraná}

Area: Plano - $54.000 \mathrm{~m}^{2}$ | Edificações - $8.000 \mathrm{~m}^{2}$

Local: Curitiba - PR

Cliente: Ministério da Educação e Cultura

Ano: 1966

1.8 Edifício Sede da Caixa Econômica Federal

Área: $18.000 \mathrm{~m}^{2}$

Local: Curitiba - PR

Cliente: Ministério da Fazenda

Ano: 1967

1.9 Instituto Nacional de Colonização e Reforma Agrária - INCRA Área: $8.000 \mathrm{~m}^{2}$

Local: Curitiba - PR

Cliente: Ministério da Agricultura

Ano: 1973

1.10 SESC - Centro de atividades

Área: $5.000 \mathrm{~m}^{2}$

Local: Londrina - PR

Cliente: Ministério da Indústria e Comércio

Ano: 1976

1.11 SESC - Centro de atividades

Área: $12.000 \mathrm{~m}^{2}$ 
Local: Curitiba - PR

Cliente: Ministério da Indústria e Comércio

Ano: 1980

\section{OBRAS PÚBLICAS E ESTADUAIS}

\subsection{Teatro Guaíra}

Capacidade: Teatro experimental (Guairinha) - 500 espectadores Área: $20.000 \mathrm{~m}^{2}$ Grande auditório e anexo - 2250 espectadores

Local: Curitiba - PR

Cliente: Secretaria de Viação e Obras Públicas do Estado do Paraná Ano: 1948

\subsection{Colégio Estadual}

Área: sem informação

Local: Rio Negro - PR

Cliente: Secretaria de Viação e Obras Públicas do Estado do Paraná Ano: 1958

\subsection{Centro Tecnológico da Universidade Federal de Santa Catarina} Área: Urbanização - 20.000 m² | Edificações - 10.000 m² $^{2}$

Local: Florianópolis - SC

Cliente: Diretoria de Obras Públicas de Santa Catarina

Ano: 1966

\subsection{Ampliação do Palácio do Governo}

Área: sem informação

Local: Curitiba - PR

Cliente: Governo do Estado do Paraná

Ano: 1973

\subsection{Plano Geral de Ocupação}

Área: $22 \mathrm{~km}^{2}$

Local: Ilha do Mel - PR

Cliente: Prefeitura Municipal de Paranaguá

Ano: 1982

\section{OBRAS PÚBLICAS - MUNICIPAIS}

3.1 Estação Rodoviária de Curitiba (Guadalupe)

Área: $4.500 \mathrm{~m}^{2}$

Local: Curitiba - PR

Cliente: Prefeitura Municipal de Curitiba

Ano: 1956

\subsection{Paço Municipal de Curitiba}

Área: Plano - $24.000 \mathrm{~m}^{2}$ | Edificação $1^{\circ}$ etapa - $11.500 \mathrm{~m}^{2}$

Local: Curitiba - PR

Cliente: Prefeitura Municipal de Curitiba

Ano: 1960

\subsection{Paço Municipal de Toledo}

Área: Urbanização - 15.000 m² | Edificações - 5.000 m²

Local: Toledo - PR

Cliente: Prefeitura Municipal de Toledo

Ano: 1964

\subsection{Feira de Amostras de Santa Catarina - Expoville}

Área: Urbanização - 170.000 m² $^{2}$ Edificações - 14.000 m²

Local: Joinville - SC

Cliente: Prefeitura Municipal de Joinville

Ano: 1967

\subsection{Estação Rodoviária de Joinville}

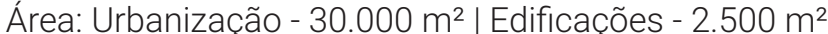

Local: Joinville - SC

Cliente: Prefeitura Municipal de Joinville

Ano: 1968

\subsection{Estação Rodoferroviária de Curitiba}

Área: Urbanização - $67.000 \mathrm{~m}^{2}$ | Edificações - 32.000 m² $^{2}$ Local: Curitiba - PR

Cliente: Prefeitura Municipal de Curitiba / RFFSA

Ano: 1969 


\subsection{Estação Rodoferroviária de Paranaguá}

Área: Urbanização - 24.000 m² | Edificações - 6.000 m²

Local: Paranaguá - PR

Cliente: Prefeitura Municipal de Paranaguá / RFFSA

Ano: 1972

\subsection{Estação Rodoviária de Toledo}

Área: Urbanização - 35.500 m² | Edificações - 5.090 m²

Local: Toledo - PR

Cliente: Prefeitura Municipal de Toledo

Ano: 1976

\subsection{Estação Rodoviária de Foz do Iguaçu}

Área: Urbanização - 60.000 m² | Edificações - 12.000 m²

Local: Foz do Iguaçu - PR

Cliente: Prefeitura Municipal de Foz do Iguaçú / DER

Ano: 1978

\subsection{Estação Rodoviária de Apucarana}

Área: Urbanização - 65.000 m² | Edificações - 10.000 m²

Local: Apucarana - PR

Cliente: Prefeitura Municipal de Apucarana / DER

Ano: 1981

\section{ENTIDADES DE ECONOMIA MISTA}

\subsection{Estação da Usina Elétrica de Figueira}

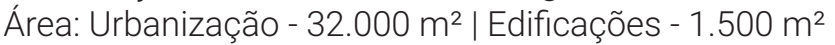

Local: Ponta Grossa - PR

Cliente: Utelfa / Copel

Ano: 1962

\subsection{Edifício Sede da Celepar}

Área: $2.770 \mathrm{~m}^{2}$

Local: Curitiba - PR

Cliente: Centro Eletrônico de Processamento de Dados do Paraná Ano: 1964

\subsection{Agência do Banestado}

Área: $2.300 \mathrm{~m}^{2}$

Local: Londrina - PR

Cliente: Banco do Estado do Paraná S.A.

Ano: 1965

\subsection{Vila de Operadores da Usina Hidrelétrica de Salto Grande do Iguaçú} Área: Urbanização - 90.000 m² | Edificações - 3.500 m²

Local: União da Vitória - PR

Cliente: Copel

Ano: 1965

\subsection{Central Hidrelétrica de Capivari Cachoeira}

Área: sem informação

Local: Antonina - PR

Cliente: Copel

Ano: 1967

\subsection{Sede da COTESC}

Área: $18.000 \mathrm{~m}^{2}$

Local: Florianópolis - SC

Cliente: Companhia Catarinense de Telecomunicações Ano: 1971

\subsection{Central Telefônica}

Área: $2.203 \mathrm{~m}^{2}$

Local: Blumenau - SC

Cliente: Companhia Catarinense de Telecomunicações

Ano: 1972

\subsection{Central Telefônica}

Área: $1.797 \mathrm{~m}^{2}$

Local: Itajaí - SC

Cliente: Companhia Catarinense de Telecomunicações Ano: 1972

\subsection{Complexo de Itaipu}

Área: Terreno - 120 hectares | Edificações - 20.000 m²

Local: Foz do Iguaçu - PR 
Cliente: Itaipu Binacional (concurso)

Ano: 1973

\subsection{Vila Residencial do Centro Executivo de Itaipu} Área: Urbanização - 30 hectares | 80 casas

Local: Foz do Iguaçu - PR

Cliente: Itaipu Binacional

Ano: 1974

\subsection{Sede Administrativa do Banestado}

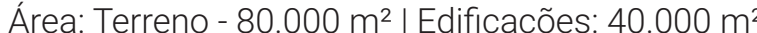

Local: Curitiba - PR

Cliente: Banco do Estado do Paraná S.A.

Ano: 1975

\subsection{Conjunto Habitacional "B"}

Área: Urbanização - 40 hectares | 105 casas

Local: Foz do Iguaçu - PR

Cliente: Itaipu Binacional

Ano: 1976/1977

\subsection{Sede Administrativa do Banestado - Interiores} Area: 40. 000m²

Local: Curitiba - PR

Cliente: Banco do Estado do Paraná S.A

Ano: 1977

\section{INDUSTRIAIS}

\subsection{Indústrias gráficas Impressora Paranaense}

Área: Urbanização - 90.000 m² | Edificações - 15.000 m²

Local: Curitiba - PR

Cliente: Impressora Paranaense S.A.

Ano: 1955

\subsection{Lumière - Tecelagem e Confecções}

Área: Urbanização - 18.000 m² | Edificações - 5.500 m²

Local: Joinville - SC
Cliente: Casimiro Silveira S.A.

Ano: 1957

\subsection{Edifício Agência Indústrias Villares}

Area: $800 \mathrm{~m}^{2}$

Local: Curitiba - PR

Cliente: Indústrias Villares S.A.

Ano: 1962

\subsection{Laminação de Metais Forpasa}

Área: $1.743 \mathrm{~m}^{2}$

Local: Curitiba - PR

Cliente: Forpasa S.A

Ano: 1963

\subsection{PESA - Catterpillar Oficinas e Administração}

Área: Urbanização - 90.000 m² | Edificações - 5.000 m²

Local: Curitiba - PR

Cliente: Paraná Equipamentos S.A.

Ano: 1963

\subsection{Calfibra}

Área: Urbanização - 71.000 m² | Edificações - 2.000 m²

Local: Bocaiúva do Sul - PR

Cliente: Calfibra S.A.

Ano: 1964

5.7 PESA - Catterpillar Oficinas e Administração

Área: Urbanização - $12.000 \mathrm{~m}^{2}$ | Edificações - $2.136 \mathrm{~m}^{2}$

Local: Londrina - PR

Cliente: Paraná Equipamentos S.A.

Ano: 1965

\subsection{Calfibra - Hidratador}

Área: sem informação

Local: Curitiba - PR

Cliente: Calfibra

Ano: 1965 


\subsection{Fundição Tupy}

Área: Urbanização - 80.000 m² | Edificações - 13.000 m²

Local: Joinville - SC

Cliente: Fundição Tupy S.A.

Ano: 1968

\subsection{Distribuidora Wib}

Área: Urbanização - $1.217 \mathrm{~m}^{2}$ | Edificações - 2.018 m²

Local: Curitiba - PR

Cliente: Distribuidora Wib Ltda.

Ano: 1968

\subsection{Siemens}

Área: Urbanização - 2.525 m² | Edificações - 1.484 m²

Local: Curitiba - PR

Cliente: Siemens do Brasil S.A.

Ano: 1970

\subsection{Refrigeração Cônsu}

Área: Urbanização - 59.000 m² | Edificações - 18.736 m²

Local: Joinville - SC

Cliente: Indústria de Refrigeração Consul S.A.

Ano: 1970

\subsection{Cerâmica Incepa}

Área: Urbanização - 8.720 m² | Edificações - 7.019 m²

Local: Campo Largo - PR

Cliente: Indústria Cerâmica Paraná S.A

Ano: 1971

\subsection{PESA - Catterpillar Oficinas e Administração}

Área: Urbanização - 8.000 m² | Edificações - 991 m²

Local: Cascavel - PR

Cliente: Paraná Equipamentos S.A

Ano: 1972

\subsection{Impressora Paranaense Indústrias Gráficas}

Área: Urbanização - 15.600 m² | Edificações - 13.959 m²

Local: Curitiba - PR
Cliente: Impressora Paranaense S.A.

Ano: 1972

\subsection{WEG Indústria de Eletromotores}

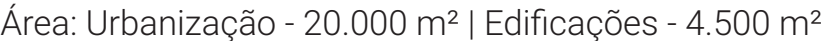

Local: Jaraguá do Sul - SC

Cliente: WEG S.A

Ano: 1982

\subsection{Fazenda Jatobá}

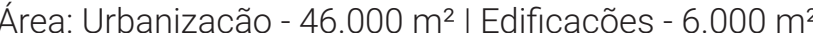

Local: Estado da Bahia - BA

Cliente: Shell Petróleo S.A.

Ano: 1982

\section{ESTABELECIMENTOS COMERCIAIS}

\subsection{Edifício Marechal Deodoro}

Area: $13.000 \mathrm{~m}^{2}$

ocal: Curitiba - PR

Cliente: Banco Hipotecário Lar Brasileiro S.A.

Ano: 1957

\subsection{Edifício Barão do Rio Branco}

Área: $14.000 \mathrm{~m}^{2}$

Local: Curitiba - PR

Cliente: Banco Hipotecário Lar Brasileiro S.A.

Ano: 1958

\subsection{Hermes Macedo - Lojas e Escritórios}

Área: $4.000 \mathrm{~m}^{2}$

Local: Curitiba - PR

Cliente: Hermes Macedo S.A.

Ano: 1958

\subsection{Móveis Cimo - Lojas e Exposição}

Área: $2.050 \mathrm{~m}^{2}$

Local: Curitiba - PR 
Cliente: Banco Hipotecário Lar Brasileiro S.A. Ano: 1958

\subsection{Hermes Macedo - Lojas e Escritórios} Área: $4.500 \mathrm{~m}^{2}$

Local: Blumenau - SC

Cliente: Hermes Macedo S.A

Ano: 1960

\subsection{Olsen - Lojas e Escritórios}

Área: sem informação

Local: Curitiba - PR

Cliente: Olsen S.A.

Ano: 1960

\subsection{Oficinas e Escritórios}

Área: $1.977 \mathrm{~m}^{2}$

Local: Curitiba - PR

Cliente: Wigando Olsen

Ano: 1962

\subsection{Hermes Macedo - Lojas e Escritórios}

Area: $2.000 \mathrm{~m}^{2}$

Local: Ponta Grossa - PR

Cliente: Hermes Macedo S.A

Ano: 1962

\subsection{Edifício Avenida}

Área: $3.751 \mathrm{~m}^{2}$

Local: Curitiba - PR

Cliente: Bamerindus.

Ano: 1962

\subsection{Hermes Macedo - Lojas e Escritórios}

Área: $8.500 \mathrm{~m}^{2}$

Local: Porto Alegre - RS

Cliente: Hermes Macedo S.A.

Ano: 1962
6.11 Hermes Macedo - Lojas e Escritórios

Área: $1.278 \mathrm{~m}^{2}$

Local: Campo Mourão - PR

Cliente: Hermes Macedo S.A.

Ano: 1964

\subsection{Supermercado}

Área: sem área

Local: Curitiba - PR

Cliente: Rodolpho Senff S.A.

Ano: 1964

6.13 Hermes Macedo - Lojas e Escritórios

Área: $1.808 \mathrm{~m}^{2}$

Local: Paranavaí - PR

Cliente: Hermes Macedo S.A.

Ano: 1967

\subsection{Supermercado}

Área: $485 \mathrm{~m}^{2}$

Local: Curitiba - PR

Cliente: S.A. Rio Mafra

Ano: 1967

\subsection{Edifício Sede Atalaia}

Área: $8.000 \mathrm{~m}^{2}$

Local: Curitiba - PR

Cliente: Atalaia / Bamerindus

Ano: 1967

6.16 Hermes Macedo - Lojas e Escritórios

Área: $3.151 \mathrm{~m}^{2}$

Local: Porto Alegre - RS

Cliente: Hermes Macedo S.A.

Ano: 1968

\subsection{Edifício Central - Agência Bamerindus} Área: $2.026 \mathrm{~m}^{2}$

Local: Curitiba - PR 
Cliente: Bamerindus

Ano: 1969

6.18 Hermes Macedo - Lojas e Escritórios Área: $5.015 \mathrm{~m}^{2}$

Local: São Paulo - SP

Cliente: Hermes Macedo S.A.

Ano: 1970

\section{CASAS DE ESPETÁCULOS}

\subsection{Cine Hotel Colón}

Capacidade: 1.200 lugares

Área: $10.500 \mathrm{~m}^{2}$

Local: Joinville - SC

Cliente: Nelson Walter

Ano: 1956

\subsection{Cine Marrocos}

Capacidade: 1.100 lugares

Área: $12.000 \mathrm{~m}^{2}$

Local: Lages - SC

Cliente: Empresa Lageana

Ano: 1962

\subsection{Cine Plaza}

Capacidade: 900 lugares

Área: $8.600 \mathrm{~m}^{2}$

Local: Castro - PR

Cliente: Empresa Plaza

Ano: 1968

\subsection{Cine Emacite}

Capacidade: 800 lugares

Área: $8.000 \mathrm{~m}^{2}$

Local: Mafra - SC

Cliente: Empresa Emacite

Ano: 1980
7.5 Teatro do SESI

Capacidade: 550 lugares

Área: $3.074 \mathrm{~m}^{2}$

Local: Curitiba - PR

Cliente: Serviço Social da Indústria

Ano: sem informação

\section{ENTIDADES DE CLASSE}

8.1 Instituto de Engenharia do Paraná - Edifício Sede Área: sem informação

Local: Curitiba - PR

Cliente: Instituto de Engenharia do Paraná

Ano: 1954

\subsection{Associação Médica de Londrina - Edifício Sede}

Area: sem informação

Local: Londrina - PR

Cliente: Associação Médica de Londrina

Ano: 1959

\section{TEMPLOS}

9.1 Igreja Matriz Nossa Senhora da Luz

Área: sem informação

Local: Clevelândia - PR

Cliente: Paróquia de Clevelândia

Ano: 1961

\subsection{Igreja Episcopal Brasileira}

Área: sem informação

Local: Curitiba - PR

Cliente: Igreja Episcopal Brasileira

Ano: 1963

9.3 Igreja Nossa Senhora Aparecida

Área: sem informação 
Local: Rio Negro - PR

Cliente: Paróquia de Rio Negro

Ano: 1967

\subsection{Igreja Matriz Santa Inês}

Área: sem informação

Local: Balneário Camboriú - SC

Cliente: Paróquia de Balneário Camboriu

Ano: 1967

\subsection{Igreja Mercês}

Área: sem informação

Local: Curitiba - PR

Cliente: Missão dos Padres Xaverianos

Ano: 1971

\subsection{Capela Luterana}

Área: sem informação

Local: Curitiba - PR

Cliente: Comunidade Luterana

Ano: 1972

\section{RESIDÊNCIAS}

10.1 Conjunto Residencial Avenida Getúlio Vargas Área: sem informação

Local: Curitiba - PR

Cliente: Banco Lar Brasileiro SA.

Ano: 1958

\subsection{Residência Leônidas Bório}

Área: sem informação

Local: Curitiba - PR

Cliente:Leônidas Bório

Ano: 1958

\subsection{Residência Antônio Bau Urius}

Área: sem informação
Local: Curitiba - PR

Cliente: Antônio Bau Urius

Ano: 1959

10.4 Seis Prédios de Apartamentos - Avenida Iguaçu

Área: sem informação

Local: Curitiba - PR

Cliente: Banco Lar Brasileiro S.A.

Ano: 1961

\subsection{Residência Carlos Schneider}

Área: sem informação

Local: Joinville - SC

Cliente: Carlos Schneider

Ano: 1962

\subsection{Residência Manoel Rosenmann}

Area: $1008 \mathrm{~m}^{2}$

Local: Curitiba - PR

Cliente: Manoel Rosenmann

Ano: 1973

\subsection{Residência Consul Felix Agüero}

Área: $650 \mathrm{~m}^{2}$

Local: Asunción - Paraguai

Cliente: Consul Felix Agüero

Ano: 1975

\subsection{Residência Jael B. Barros}

Área: $1380 \mathrm{~m}^{2}$

Local: Curitiba - PR

Cliente: Jael B. Barros

Ano: 1976

10.9 Residência José Eduardo Todeschini

Área: $474 \mathrm{~m}^{2}$

Local: Curitiba - PR

Cliente: José Eduardo Todeschin

Ano: 1977 
10.10 Residência Agüero - Cortesse

Área: $436 \mathrm{~m}^{2}$

Local: Asunción - Paraguai

Cliente: Agüero - Cortesse

Ano: 1977

10.11 Residência Nelson Marques

Área: $465 \mathrm{~m}^{2}$

Local: Curitiba - PR

Cliente: Nelson Marques

Ano: 1977

\subsection{Residência Carlos Odebrecht}

Área: $450 \mathrm{~m}^{2}$

Local: Blumenau - SC

Cliente: Carlos Odebrecht

Ano: 1979

10.13 Residência Walter Jiraschek

Área: $1200 \mathrm{~m}^{2}$

Local: Curitiba - PR

Cliente: Walter Jiraschek

Ano: 1982 


\section{Obras reconhecidas e ausentes no currículo oficial}

52 projetos

Fonte: Caderno de anotações presente no acervo Rubens Meister e livro

Rubens Meister: Projeto e Obra (CARVALHO; BATISTA; CHIESA, 2019)

\section{OBRAS PÚBLICAS - ESTADUAIS}

\subsection{Panteão dos Heróis da Lapa}

Área: sem informação

Local: Lapa - PR

Cliente: sem informação / Concurso

Ano: 1943

\subsection{Grupo Escolar Tiradentes}

Área: sem informação

Local: Curitiba - PR

Cliente: Secretaria de Obras do Paraná

Ano: 1951

\section{ESTABELECIMENTOS COMERCIAIS}

\subsection{Loja Renaux}

Área: sem informação

Local: Curitiba - PR

Cliente: Fábrica de Tecidos Carlos Renaux

Ano: 1952

2.2 Revitalização do Palácio Avenida - Restauração e interiores

Area: $15.000 \mathrm{~m}^{2}$

Local: Curitiba - PR

Cliente: Banco Bamerindus

Ano: 1987

\subsection{Loja}

Área: $90 \mathrm{~m}^{2}$
Local: Cascavel - PR

Cliente: Manoel Rosenmann

Ano: sem informação

\subsection{Loja}

Área: $850 \mathrm{~m}^{2}$

Local: Foz do Iguaçu - PR

Cliente: Paraná Equipamentos S.A.

Ano: sem informação

\subsection{Joalheria Boiko}

Área: $800 \mathrm{~m}^{2}$

Local: Curitiba - PR

Cliente: Chaim Leib Boiko

Ano: sem informação

\subsection{Bergerson Joalheiros}

Área: $500 \mathrm{~m}^{2}$

Local: Curitibal - PR

Cliente: M. Bergerson

Ano: sem informação

\subsection{Loja - Ampliação e Reforma}

Área: 860,89 m²

Local: Guarapuava - PR

Cliente: J. V. Oliveira

Ano: sem informação

\subsection{Loja}

Área: 991,42 m² $^{2}$

Local: Cascavel - PR 
Cliente: Paraná Equipamentos

Ano: sem informação

\subsection{Loja}

Área: 991,42 m²

Local: Cascavel - PR

Cliente: Paraná Equipamentos

Ano: sem informação

\subsection{Hotel Curitiba}

Area: sem informação

Local: Curitiba - PR

Cliente: sem informação

Ano: 1962

\section{Edifício A.S.A.}

Área: sem informação

Local: Curitiba - PR

Cliente: Aranha S.A.

Ano: 1952

\section{CASAS DE ESPETÁCULOS}

3.1 Teatro Edifício Lydio Paulo Bettega (SESI/FIEP)

Capacidade: 550 lugares

Área: $3.074 \mathrm{~m}^{2}$

Local: Curitiba - PR

Cliente: Serviço Social da Indústria

Ano: 1962

\subsection{Teatro Municipal}

Area: sem informação

Local: Joinville - SC

Cliente: Prefeitura Municipal de Joinville

Ano: 1978

\section{ENTIDADES DE CLASSE}

\subsection{Edifício Centro Cultural}

Área: $500 \mathrm{~m}^{2}$

Local: São Mateus do Sul - PR

Cliente: Associação Desportiva Petros IX - ADESPE

Ano: sem informação

\subsection{Conjunto de Lazer}

Área: Urbanização - 3.000 m² Edificações - 300 m²

ocal: São Mateus do Sul - PR

Cliente: Superintendência da Industrialização do Xisto - SIX

Ano: sem informação

\section{TEMPLOS}

\subsection{Igreja Bom Pastor}

Área: sem informação

Local: Curitiba - PR

Cliente: Centro Comunitário

Ano: 1967

\subsection{Igreja de Santo Antônio}

Área: $789,50 \mathrm{~m}^{2}$

Local: Campo Largo - PR

Cliente: sem informação

Ano: 1987

\subsection{Complexo Comunitário Schoenstatt Magnificat}

Área: sem informação

Local: Curitiba - PR

Cliente: Igreja dos Peregrinos

Ano: sem informação

\subsection{Centro Catequético}

Área: 964,56 m²

Local: Campo Largo - PR

Cliente: Paróquia Nossa Senhora da Piedade 
Ano: sem informação

\section{RESIDÊNCIAS}

6.1 Residência Carlos A. O. Franco

Area: $381,20 \mathrm{~m}^{2}$

Local: Curitiba - PR

Cliente: Carlos A O. Franco

Ano: sem informação

\subsection{Residência Manfred Schimidt}

Área: 399,95 m²

Local: Curitiba - PR

Cliente: Manfred Schimidt

Ano: sem informação

\subsection{Residência Eduardo Hasenauer} Área: $487,07 \mathrm{~m}^{2}$

Local: Curitiba - PR

Cliente: Eduardo Hasenauer

Ano: sem informação

\subsection{Residência Teodoro Buest}

Área: $211,05 \mathrm{~m}^{2}$

Local: Curitiba - PR

Cliente: Teodoro Buest

Ano: sem informação

\subsection{Residência Afonso Gostchild}

Área: $173 \mathrm{~m}^{2}$

Local: Caiobá - PR

Cliente: Afonso Gostchild

Ano: sem informação

\subsection{Residência Ítalo Stof}

Area: $290 \mathrm{~m}^{2}$

Local: Joinville - SC

Cliente: Ítalo Stolf

Ano: sem informação
6.7 Residência Luiz Sergio Trombini

Área: 548,86 m²

Local: Curitiba - PR

Cliente: Luiz Sergio Trombini

Ano: sem informação

\subsection{Residência Eduardo Hasenauer}

Área: $143,58 \mathrm{~m}^{2}$

Local: Curitiba - PR

Cliente: Eduardo Hasenauer

Ano: sem informação

\subsection{Residência Rogério M. Bório}

Área: 343,90 m²

Local: Curitiba - PR

Cliente: Rogério M. Bório

Ano: sem informação

\subsection{Residência Luiz F. Aguiar}

Área: $373 \mathrm{~m}^{2}$

Local: Curitiba - PR

Cliente: Luiz F. Aguiar

Ano: sem informação

\subsection{Residência Aloísio Forneck}

Área: $381,20 \mathrm{~m}^{2}$

Local: Curitiba - PR

Cliente: Aloísio Forneck

Ano: sem informação

6.12 Residência Sergio de O. Ribas

Área: $680 \mathrm{~m}^{2}$

Local: Curitiba - PR

Cliente: Sergio de O. Ribas

Ano: sem informação

\subsection{Residência Egon João da Silva} Área: $702 \mathrm{~m}^{2}$

Local: Jaraguá do Sul 
Cliente: Egon João da Silva

Ano: sem informação

\subsection{Residência Edgard N. Maister}

Área: 520,74 m²

Local: Joinville - SC

Cliente: Edgard N. Maister

Ano: sem informação

\subsection{Residência José Eduardo A. Vieira}

Área: $717 \mathrm{~m}^{2}$

Local: Curitiba - PR

Cliente: José Eduardo A. Vieira

Ano: sem informação

\subsection{Edifício Kamy}

Área: $1.394 \mathrm{~m}^{2}$

Local: Curitiba - PR

Cliente: RLD

Ano: sem informação

\subsection{Edifício Mona Lisa}

Área: $2.773 \mathrm{~m}^{2}$

Local: Curitiba - PR

Cliente: Jael B. Barros

Ano: sem informação

\subsection{Conjunto Habitaciona}

Área: $2.832 \mathrm{~m}^{2}$

Local: Caiobá - PR

Cliente: R. J. Teig

Ano: sem informação

\subsection{Conjunto Habitacional}

Área: $116.985 \mathrm{~m}^{2}$

Local: Balneário Camboriú - SC

Cliente: Soifer, Berman \& CIA. LTDA.

Ano: sem informação
6.20 Residência Alberto Franco Ferreira da Costa

Área: sem informação

Local: Curitiba - PR

Cliente: Alberto Franco Ferreira da Costa

Ano: sem informação

\subsection{Residência Ariel Amaral}

Área: $640 \mathrm{~m}^{2}$

Local: Curitiba - PR

Cliente: Ariel Amaral

Ano: sem informação

\subsection{Residência Plínio Pessoa}

Área: $450 \mathrm{~m}^{2}$

Local: Curitiba - PR

Cliente: Plínio Pessoa

Ano: sem informação

\subsection{Residência Heliantho Camargo}

Área: $380 \mathrm{~m}^{2}$

Local: Curitiba - PR

Cliente: Heliantho Camargo

Ano: sem informação

\subsection{Residência Arnoldo Gaensly}

Área: $350 \mathrm{~m}^{2}$

Local: Curitiba - PR

Cliente: Arnoldo Gaensly

Ano: sem informação

\subsection{Residência Felipe Friollo}

Área: $460 \mathrm{~m}^{2}$

Local: Curitiba - PR

Cliente: Felipe Friollo

Ano: sem informação

\subsection{Residência Milton Pettersen}

Área: $420 \mathrm{~m}^{2}$

Local: Curitiba - PR 
Cliente: Milton Pettersen

Ano: sem informação

6.27 Residência Egon Freitag

Área: sem informação

Local: Penha - SC

Cliente: Egon Freitag

Ano: sem informação

\subsection{Residência Miguel Meister}

Área: $450 \mathrm{~m}^{2}$

Local: Curitiba - PR

Cliente: Miguel Meister

Ano: sem informação

6.29 Residência Lauro Grein Filho

Área: $750 \mathrm{~m}^{2}$

Local: Curitiba - PR

Cliente: Lauro Grein Filho

Ano: sem informação

\subsection{Residência e Escritório}

Area: 517,10 m²

Local: Apucarana - PR

Cliente: Fazenda Ubatuba Agropecuária Industrial S.A

Ano: sem informação

\subsection{Residência Guilherme Lacerda Braga Sobrinho}

Área: $320 \mathrm{~m}^{2}$

Local: Curitiba - PR

Cliente: Guilherme Lacerda Braga Sobrinho

Ano: sem informação 
